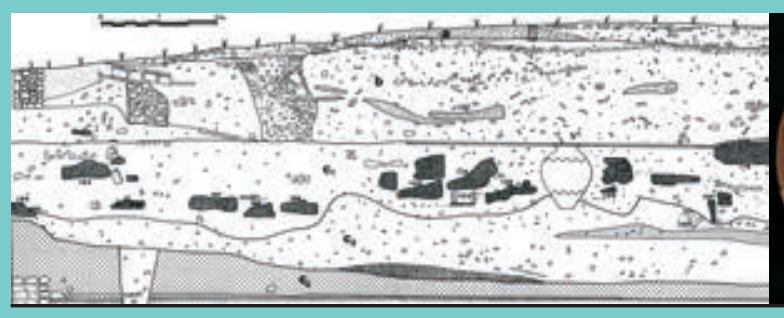

La necrópolis occidental de Caesaraugusta en el siglo III

(Calle Predicadores, 20-30, Zaragoza)

\title{
(3) Zaragoza
}





\section{LA NECRÓPOLIS OCCIDENTAL \\ DE CAESARAUGUSTA EN EL SIGLO III \\ (Calle Predicadores, 20-30, Zaragoza)}





\title{
LA NECRÓPOLIS OCCIDENTAL DE CAESARAUGUSTA EN EL SIGLO III \\ (Calle Predicadores, 20-30, Zaragoza)
}

\author{
Maria Pilar Galve Izquierdo
}

Estudio antropológico:

Salvador Baena Pinilla, Jesús Angel Obón, José Luis Nieto Amada 


\section{FICHA CATALOGRÁFICA}

\section{GALVE IZQUIERDO, María Pilar}

La necrópolis occidental de Caesaraugusta en el siglo III : (calle Predicadores, 20-30, Zaragoza) / María Pilar Galve Izquierdo ; estudio antropológico: Salvador Baena Pinilla, Jesús Ángel Obón, José Luis Nieto Amada. — Zaragoza : Prensas Universitarias de Zaragoza : Ayuntamiento de Zaragoza : Institución «Fernando el Católico», 2008

263 p. : il. col. y n. ; $22 \mathrm{~cm}$. - (Ciencias sociales ; 72)

\section{ISBN 978-84-92521-52-4}

1. Zaragoza-Restos arqueológicos romanos-S. III. 2. Restos humanos-Zaragoza-S. III. I. Baena Pinilla, Salvador. II. Obón, Jesús Ángel. III. Nieto Amada, José Luis. IV. Prensas Universitarias de Zaragoza. V. Serie: Ciencias sociales (Prensas Universitarias de Zaragoza) ; 72. VI. Serie: Publicación de la Institución «Fernando el Católico» ; n. 2832

$$
\begin{aligned}
& \text { 7.032:904(460.224Zaragoza }) \ll 02 » \\
& \text { 616: } 904(460.224 \text { Zaragoza }) \ll 02 »
\end{aligned}
$$

Cualquier forma de reproducción, distribución, comunicación pública o transformación de esta obra solo puede ser realizada con la autorización de sus titulares, salvo excepción prevista por la ley. Diríjase a CEDRO (Centro Español de Derecho Reprográficos, www.cedro.org) si necesita fotocopiar o escanear algún fragmento de esta obra.

(C) Los autores

(C) De la presente edición, Prensas Universitarias de Zaragoza y Ayuntamiento de Zaragoza $1 .^{\mathrm{a}}$ edición, 2008

Ilustración de la cubierta: José Luis Cano

Dibujos: Begoña del Rincón, Inmaculada Soriano y Alfredo Blanco

Colección Ciencias Sociales, n. ${ }^{\circ} 72$

Director de la colección: Pedro Rújula López

Prensas Universitarias de Zaragoza. Edificio de Ciencias Geológicas, c/ Pedro Cerbuna, 12 50009 Zaragoza, España. Tel.: 976761 330. Fax: 976761063

puz@unizar.es http://puz.unizar.es

Institución «Fernando el Católico». Diputación de Zaragoza. Plaza de España, 2. 50071 Zaragoza, España. Tel.: 976288 878/9. Fax: 976288869

ifc@dpz.es http://ifc.dpz.es

Publicación número 2832

Prensas Universitarias de Zaragoza es la editorial de la Universidad de Zaragoza, que edita e imprime libros desde su fundación en 1542.

Impreso en España

Imprime: INO Reproducciones, S.A.

D.L.: Z-4312-2008 
Dentro de poco serás ceniza o esqueleto. Serás un nombre o ni siquiera un nombre. Tu nombre será un ruido o tal vez un eco.

Marco Aurelio, Meditaciones, V, 33.1 



\section{CAPÍTULO I \\ INTRODUCCIÓN AL PANORAMA \\ FUNERARIO DE CAESARAUGUSTA}

El origen de este trabajo estuvo propiciado por una excavación arqueológica, una más entre las numerosas que se acometieron en los años ochenta y cuyo motivo era la liberación de solares para la edificación de viviendas en el Casco Histórico de Zaragoza, tras la demolición de antiguos o viejos edificios. En los solares de la calle Predicadores, entonces los n. ${ }^{\text {os }} 20-30$, la fortuna quiso que se conservara una potente estratigrafía de hasta cinco metros de espesor y que tan solo en la parte correspondiente de la fachada hubiese perforaciones de bodegas.

El proceso de excavación, que se presentó algo alterado por la impaciencia de los gestores del urbanismo municipal de entonces, proporcionó novedades que voy a tratar de sintetizar. En primer lugar, la existencia de una domus construida en la época fundacional de la colonia, cuyo abandono y destrucción parece datar en época tan temprana como el reinado de Nerón. La causa para este hecho se desconoce y cualquiera que se adujera pertenecería al mundo de las hipótesis. Probablemente, si algún día se consiguen analizar los restos hallados en otros solares de la zona, también excavados ya hace años, se encuentre la explicación a este suceso, tan interesante para el conocimiento de un urbanismo romano que está sin estudiar (Galve, 2004, pássim). Hallazgos recientes bajo las calzadas de calles cercanas (San Blas, Las Armas, Casta Álvarez...) son indicativos de la existencia de población urbana durante los primeros decenios de vida de la ciudad romana (fuentes públicas, cisternas, establecimientos termales e industriales...). La presencia en la documentación arqueológica de esta zona de la ciudad de elementos urbanís- 
ticos puede circunscribirse en la actualidad a tres tipos de estructuras: domésticas, industriales y funerarias, es decir, aquellos elementos susceptibles de reconocer en suburbia.

La zona que se va a contemplar que, en un principio, por su ubicación en el camino de salida de la ciudad debió tratarse de una vía funeraria, se dedicó durante más de mil años a área cementerial, perdurando esta función en época tardoantigua y durante toda la ocupación islámica hasta la conquista cristiana. El resto de su historia posterior, conocida a través de la excavación, corresponde a estructuras domésticas y artesanales datadas en época medieval y moderna.

La costumbre romana de que los muertos fueran enterrados a la salida de las ciudades y fuera de ellas se ha evidenciado como era de esperar también en esta ciudad. Es aquí — no podía ser de otra manera - donde radican los hallazgos de las dos principales necrópolis de la ciudad romana desde época altoimperial. Así, a la salida de la Puerta Occidental y en la Vía hacia Asturica Augusta, en la calle Predicadores, se ubicaba la necrópolis que es objeto de este trabajo, y, en una zona más alejada de la Puerta Oriental y en las proximidades de la vía que conduciría a Celsa, la necrópolis oriental, con los enterramientos de la calle Nuestra Señora del Pueyo, en el barrio zaragozano de Las Fuentes. Ambas áreas cementeriales se encontraban, pues, en las orillas de las calzadas que salían de la colonia — no hay que olvidar que las ciudades romanas no tenían cementerios propiamente dichos, sino que las tumbas y monumentos jalonaban las vías, de ahí la denominación germana, muy utilizada también en nuestro país «Graberstrassen», o la inglesa «Streets of Tombs». Así sucede, por ejemplo, en la Via Apia en Roma o en la Porta Nocera en Pompeya, por señalar algunas de las mejor conocidas, mientras que en la Hispania Tarraconense cabría destacar por su actualidad la vía funeraria de la necrópolis occidental de Barcino, en la puerta decumana (Beltrán de Heredia, 2007).

Las márgenes de esta calzada debieron presentar monumentos desde comienzos de la fundación de la colonia cesaraugustana y perseverar de manera que irían ocupándose sucesivamente también para este menester los espacios tras ellos.

De forma reiterada se ha utilizado en estas páginas el término necrópolis, generalizado de forma unitaria por los arqueólogos como referencia a lugares de enterramiento. No obstante, parece oportuno recordar que el 
vocablo nunca se empleó ni por parte de griegos ni de romanos, sino que surgió en el vocabulario administrativo durante la Revolución francesa y que Gustave Flaubert lo utilizó en 1842 en la lengua francesa literaria, aplicándolo a los cementerios de Carthago (Leveau, 1987a, 289).

Los monumentos funerarios reconocidos en Zaragoza en la actualidad son dos, si bien hay indicios de la existencia de algún otro en el mismo suburbio occidental. ${ }^{1}$ La escasez de hallazgos de edificios de este tipo es un hecho habitual, ya que sirvieron de canteras de expolio por sus materiales pétreos, como lo hicieron también los edificios. Es posible que más de un sillar de la muralla que se conserva en la avenida de César Augusto (tramo de San Juan de los Panetes) procediera de monumentos funerarios de la necrópolis occidental, como parece el caso de la inscripción funeraria femenina que puede verse en la actualidad formando parte del Torreón romano de La Zuda. Los dos mausoleos citados debieron ser contemplados por los caminantes que llegaban o salían de la ciudad: la aedicula de la necrópolis occidental que trataremos más adelante, y el mausoleo posiblemente turriforme que hubo en la vía que iba al este en ruta hacia Celsa por la orilla derecha del Ebro (calle Manuela Sancho angular a la calle Torre). ${ }^{2}$

Con los datos arqueológicos que poseemos, y como era de esperar, el panorama funerario de la colonia Caesaraugusta no parece diferir del que presentaban otras capitales hispanas. En el caso del área funeraria occidental se comenzarían a erigir mausoleos a ambos lados de la vía de salida de la ciudad ya en el periodo inicial de la colonia, al igual que sucedería con las demás calzadas. Progresivamente, puede suponerse que se irían ocupando espacios en segunda fila tras los anteriores, en los que habría también establecimientos industriales y algunas casas de tipo residencial, como se ha venido demostran-

1 En el solar de la calle Predicadores, 20-22, junto al callejón del Arpa, y en una zona próxima al trazado de la vía, se excavó una estructura con muros de barro que presentaban ambas caras enlucidas y con restos de pintura. La parcialidad del hallazgo no permite otorgarle la categoría de monumento, pero tampoco puede excluirse. En su contexto se halló una moneda de Adriano (n. ${ }^{\circ}$ sigla: 89.66/586; n. ${ }^{\circ}$ Monetario Ayuntamiento: 168). Dicha estructura estaba a solo unos metros de la Incineración III, para la que también hemos sugerido un mausoleo.

2 La ubicación de este posible monumento torre en el punto más cercano al río Huerva del recinto urbano de la colonia romana podría determinar otra vía al sur hacia un lugar del río donde ha existido un puente tradicionalmente. En la excavación dirigida por F. A. Escudero en 1990 se halló un gran fragmento de bóveda en opus caementicium, y en el mismo contexto se halló un cráneo. 
do en excavaciones arqueológicas de ciudades como Tarragona, Córdoba, Mérida o Valencia. En estas ciudades las superficies afectadas por el urbanimo actual sobrepasan los cascos antiguos y ello proporciona datos importantes sobre los alrededores o suburbios de la época romana, ampliándose el conocimiento de temas como el funerario, además del industrial o residencial.

Pero este fenómeno únicamente se ha podido comprobar en esta parte de la ciudad, zona para la que, por las características apuntadas, parece adecuada la utilización de suburbium. Aquí la ocupación funeraria, que surgiría ya en el siglo I, iría creciendo a lo largo del siglo II y avanzando en el siglo III, etapa de plena antigüedad a la que pertenecen la mayoría de las tumbas halladas en estos solares de la calle Predicadores ${ }^{3}$ y que por su homogeneidad se presta a que se pueda considerar un grupo social o familiarmente relacionado como se verá más adelante.

La práctica funeraria siguió ejerciéndose en época tardoantigua, etapa escasamente documentada en estos solares debido, sin duda, a la excavación de tumbas durante la ocupación islámica, que por estar a menor profundidad resultaron muy afectadas. En cambio, la fortuna ha hecho que se conservaran en otra zona muy próxima del mismo suburbio un grupo de tumbas que se han datado desde finales del siglo IV hasta el siglo IX (grupo cristiano de las calles Dosset y San Blas) (Galve et al., 2005, pássim).

Con anterioridad al hallazgo de las dos áreas funerarias citadas, a uno y otro lado de la planta de la colonia, fueron descubiertas a mediados de los años setenta varias tumbas en el paseo de Echegaray y Caballero que se han datado en los siglos III-IV (Beltrán et al., 1980, 211-212; Beltrán, 1991, 26-27). A este hallazgo se ha venido denominando Necrópolis Norte por su excavador, aunque es probable que se tratara más bien de enterramientos tardíos: dos tumbas, una de ellas con tosco e incompleto aparejo de piedra (la $\left.n .^{\circ} 1\right)$, y otra con cubierta de tegula plana y argamasa (la n. ${ }^{\circ} 2$ ), y un fragmento de caja pétrea monolítica (la n. ${ }^{\circ} 3$ ). La zona excavada fue muy reducida; no obstante, a mi juicio, estos enterramientos habría que emparentarlos tipológicamente con los cristianos ya citados y que hemos datado a finales del siglo IV o comienzos del v.

3 Se tienen noticias orales de unos posibles enterramientos de urnas de incineración, en cerámica de tradición ibérica, que aparecieron durante las obras de remodelación de la plaza de Europa hacia 1990. Lamentablemente no se cuenta con más datos. 


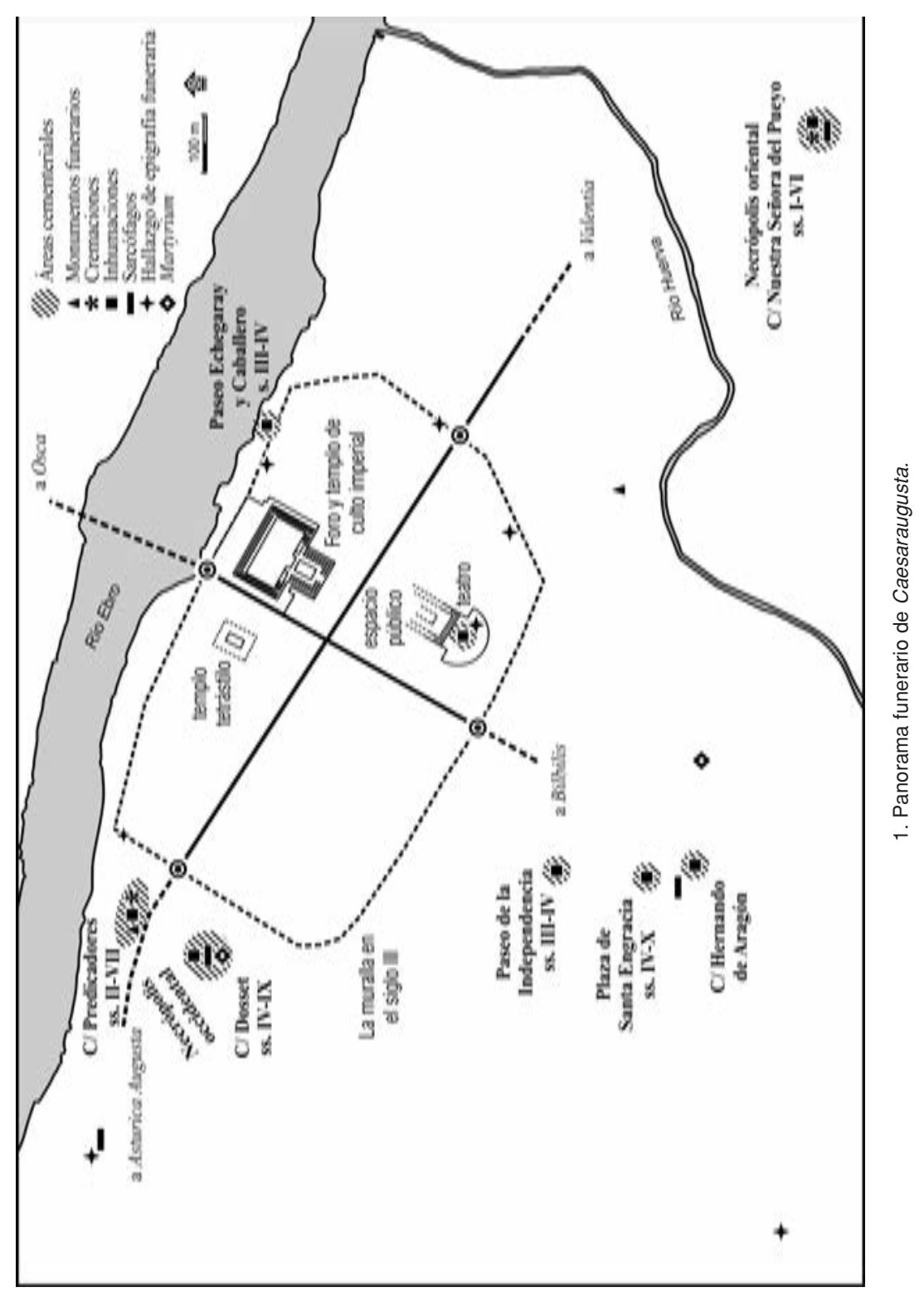


La necrópolis meridional, que debió estar situada en la zona de la antigua Huerta de Santa Engracia, tiene un hermoso testimonio, además de la referencia de Prudencio a la basílica cementerial: los dos sarcófagos romanocristianos que se conservan actualmente en la basílica de Santa Engracia (Mostalac, 1994, pássim). No se tiene en cambio noticia de hallazgos romanos anteriores a la cristianización, por lo que, de momento, parece lógico pensar en unos terrenos libres de restos funerarios en los que, según reciente hipótesis, se ubicaría un recinto funerario, basílica o martyrium a la que habría pertenecido el mosaico hallado en la calle Costa (Aguarod, Mostalac, 1997, 37; Galve, Mostalac, 2007, 92).

La necrópolis oriental fue excavada por C. Aguarod a finales de los ochenta y constituye el área cementerial de época romana más extensa localizada hasta la fecha. Estaba ubicada en la zona sureste, relativamente alejada del recinto murado, en el actual barrio de Las Fuentes (calle de Nuestra Señora del Pueyo). Se accedería a ella por la vía que, procedente de la puerta romana (oriental, después puerta de Valencia), debía cruzar el río Huerva en dirección hacia Celsa (Velilla de Ebro, Zaragoza). El área excavada contenía diecisiete enterramientos en urnas cinerarias, algunos de ellos con objetos utilizados en los funerales (balsamarios, lucernas, botellas de vidrio para perfumes) datados en el siglo I, con un vacío de varios siglos hasta llegar a inhumaciones carentes de ajuar y con una datación en época tardorromana e hispanovisigoda (siglos IV-VI) de las que se excavaron cuarenta y cuatro (Aguarod, 1991a, 23-26; Galve, Mostalac, 2007, 91). Posteriormente, se llevaron a cabo algunas intervenciones en otros solares a cargo de empresas cuyo resultado desconocemos. 


\section{CAPÍTULO II \\ EL GRUPO FUNERARIO DEL SIGLO III}

\section{La excavación arqueológica}

La excavación del grupo de sepulturas de la calle Predicadores de Zaragoza fue llevada a cabo por un equipo de la Sección de Arqueología del Ayuntamiento de Zaragoza ${ }^{4}$ durante varios meses de los años 1987 y 1988. $\mathrm{Al}$ ser derribadas las casas correspondientes a los números 20-30, que estaban alineadas en la fachada norte de dicha calle, y al solicitarse la licencia de construcción para los solares, la normativa vigente exigía la realización de catas comprobatorias, que resultaron positivas, y por ello su excavación arqueológica. ${ }^{5}$ El trabajo se circunscribió a la mayor parte de la superficie de estos tres solares (números 20-22, 24-26 y 28-30), ya que habían acumulado y conser-

4 El trabajo arqueológico se realizó por la Sección Municipal de Arqueología del Ayuntamiento de Zaragoza, organismo promotor que aplicó la normativa que, incluida dentro del Plan General de Ordenación Urbana de la Ciudad, documento Normas Urbanísticas, título Octavo, capítulo I: Niveles y Normas de Protección, art. 8.1.1, protegía el patrimonio arqueológico del Casco Histórico de la ciudad.

5 La dirección estuvo a cargo de la autora, que contó con la valiosa ayuda de J. A. Benavente, a quien desde aquí agradecemos su entusiasmo sin límites, que debe hacerse además extensible a todo el personal de la Sección de Arqueología que participó con más o menos intensidad en el proceso de excavación: P. Cameo, J. M. Fras, A. Horna, L. M. Pérez, C. J. Aguarón, J. Gil, J. M. Imas, I. Martínez, A. Morillas, D. Rubio, J. Gil, A. Gracia. También se vieron involucrados de diversa manera los compañeros técnicos de la Sección: C. Aguarod, R. Erice, F. Escudero y A. Mostalac.

Es nuestro deber tambien agradecer el interés sobresaliente demostrado por los profesores D. Guillermo Fatás — sin su oportunísima demanda pública no hubieran podido llevarse a 
vado en el subsuelo estratigrafía de épocas muy diversas, quedando solamente liberadas de los trabajos de excavación las zonas adyacentes a la calle por contar con bodegas en la fachada de los edificios derribados.

De los tres solares citados cabe destacar, por la importancia de sus restos arqueológicos y por la potencia de los niveles conservados, el correspondiente a los números 24-26; asimismo, fue el que mayor número de enterramientos proporcionó y al que pudo dedicarse un tiempo de excavación más prolongado, así como mayor cantidad de personal y mano de obra especializada. La estratigrafía más compleja y la mayor densidad de enterramientos fue contabilizada en la zona septentrional del solar, lindando con la calle Abén-Aire. Respecto a los otros dos solares excavados, el correspondiente a las casas números 20-22, resultó ser muy interesante por las estructuras de época fundacional que se detectaron, ofreciendo tan solo una sepultura quizá monumental (Inc. III), mientras que el de los números 28-30 - que aportó una inhumación (T. X) - sobresalió por sus restos industriales de época tardorromana, ${ }^{6}$ por los numerosos enterramientos de época islámica (Galve, 1995 , $117-136)$ y por interesantes pozos ciegos. ${ }^{7}$

\section{Las estructuras antiguas}

La amplia secuencia estratigráfica a la que se acaba de hacer referencia presentó, con la misma fortuna, y con la excepción de numerosos pozos ciegos que pertenecieron a casas allí ubicadas desde el siglo XIII al XX, estructuras arqueológicas correspondientes a diversas épocas. De estas estructuras,

cabo estos descubrimientos-, D. Manuel Martín Bueno y por D. ${ }^{a}$ M. ${ }^{a}$ Luisa Cancela de Arellano. Durante dos meses se contó con la colaboración de tres operarios aportados por la promotora, y durante gran parte de la excavación con la presencia de los entonces estudiantes de Arqueología de la Universidad de Zaragoza, que también colaboraron posteriormente en el trabajo de laboratorio: P. Cáceres, P. A. Paracuellos, R. Mozo, R. Pinto, M. A. Sampietro, M. P. Sarto. La cartografía fue realizada por el topógrafo municipal P. Fuentes. Los trabajos de restauración in situ los llevó a cabo la restauradora por entonces de la Sección de Arqueología M. ${ }^{a}$ Teresa Valtueña. La dirección técnica del levantamiento de los restos humanos corrió a cargo de I. Lorenzo Lizalde.

6 En una zona próxima a la fachada aparecieron unas estructuras pertenecientes a un horno de fundición. En dicho solar continuó la presencia del muro de la casa del siglo I, que penosamente pudo ser situado planimétricamente, puesto que nuestra presencia allí no podía prolongarse más, quedando gran parte del solar sin excavar, como consta en el informe final emitido por la dirección.

7 Es notablemente sobresaliente el material hallado en el pozo n. 13, datado a comienzos del siglo XV, con cerámica de reflejo metálico y dos florines aragoneses (Escudero, 1991). En la actualidad está siendo estudiado por Alejandra Gutiérrez (Universidad de Durham, Gran Bretaña). 
que nos indican la ocupación del terreno en un amplio espacio temporal, abarcando la época moderna, medieval y romana de la ciudad, merecen destacarse las que se citan a continuación.

De la época medieval cristiana, es decir, con posterioridad a la conquista de Zaragoza por Alfonso I (1118) y tras fundarse a comienzos del siglo XIII el barrio de la Población del Rey, se hallaron estructuras pertenecientes a una almazara que puede identificarse con dependencias del molino de aceite que, ya desde el siglo XIII, fuentes medievales ubican en la calle Predicadores, junto a la de Bonaire (Abén-Aire en el momento de realizar la excavación) (Galve, 1990, 322-323), y, precisamente, sobre el pavimento de una estanciaalmacén se encontraron tres dineros jaqueses de Jaime II (1291-1327), además de una significativa representación de cerámica de la época.

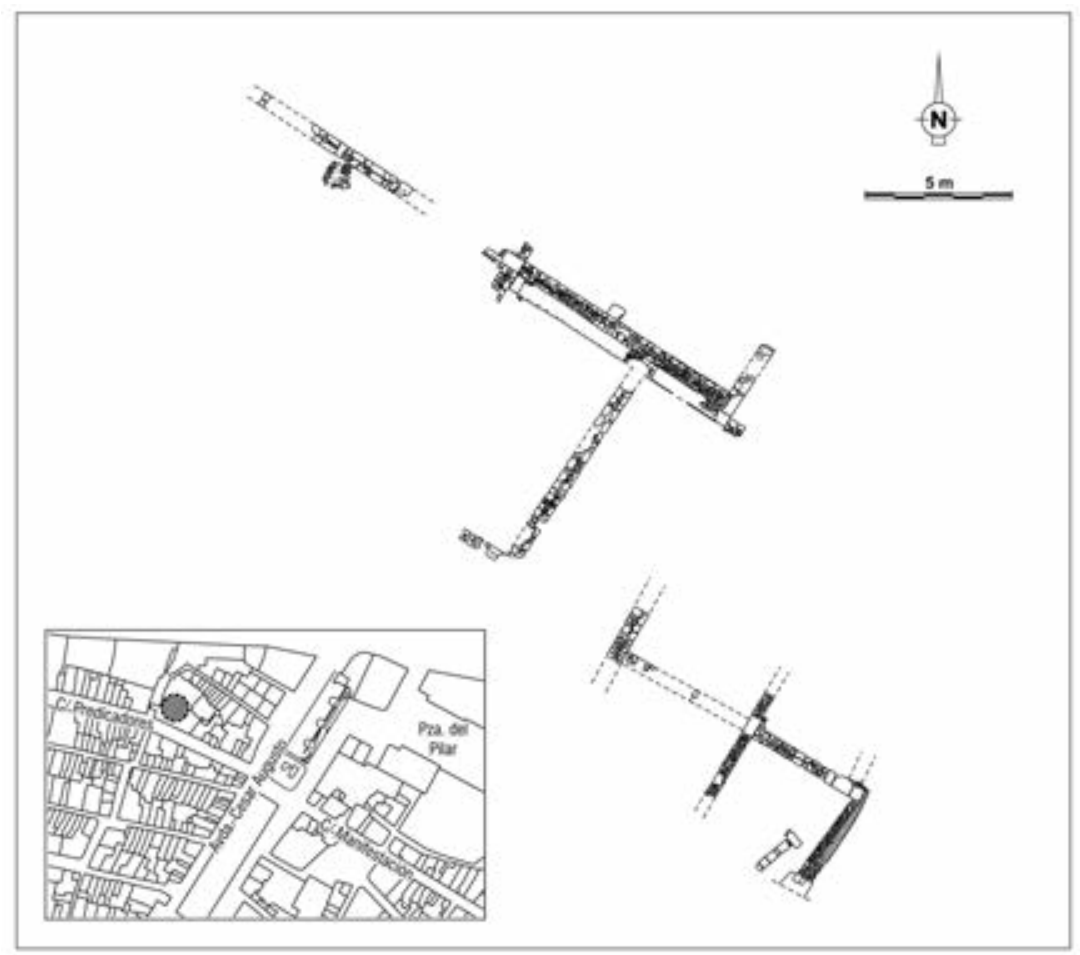

2. Planimetría de las estructuras pertenecientes a la domus de época fundacional. 


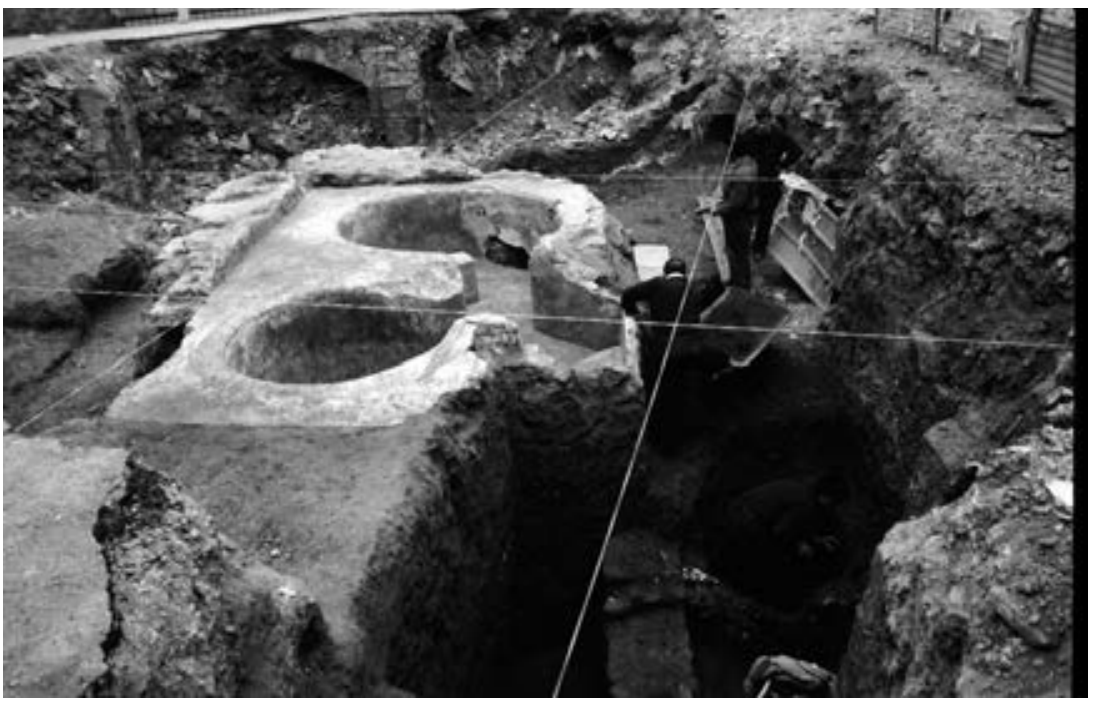

3. Estructura perteneciente a la almazara bajomedieval. Debajo y a la derecha, excavación de un muro de la casa romana.

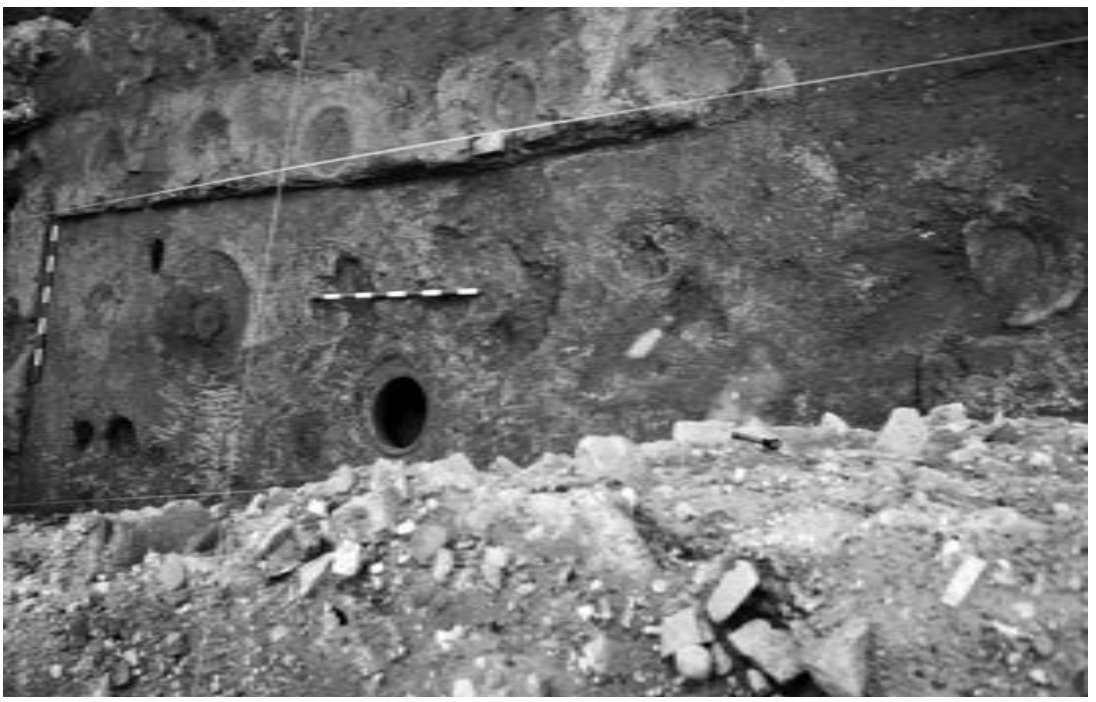

4. Almacén de la almazara. Pueden verse las huellas de las tinajas en el banco y suelo de yeso y el desagüe formado por una tinaja, que se conserva completa en los almacenes municipales. 
Pero, sin duda, más interesante se presentó el hallazgo del cementerio de época islámica de la puerta de Toledo en estos mismos solares, ${ }^{8}$ cuyas tumbas, más de trescientas, se conservaban intactas a pesar de haber tres niveles de enterramientos superpuestos. La cronología abarca desde los primeros años de la invasión, datando de los siglos IX, X y XI. ${ }^{9}$ Y la importancia radica en que, con excepción de varios pozos ciegos que habían destruido parcialmente los enterramientos, el cementerio estaba presente en toda la zona posterior del solar salvo en la que se encontraban las fosas de la almazara, que por estar excavados en tierra bajo el nivel del suelo, debieron perforar y barrer las tumbas que encontraron a su paso.

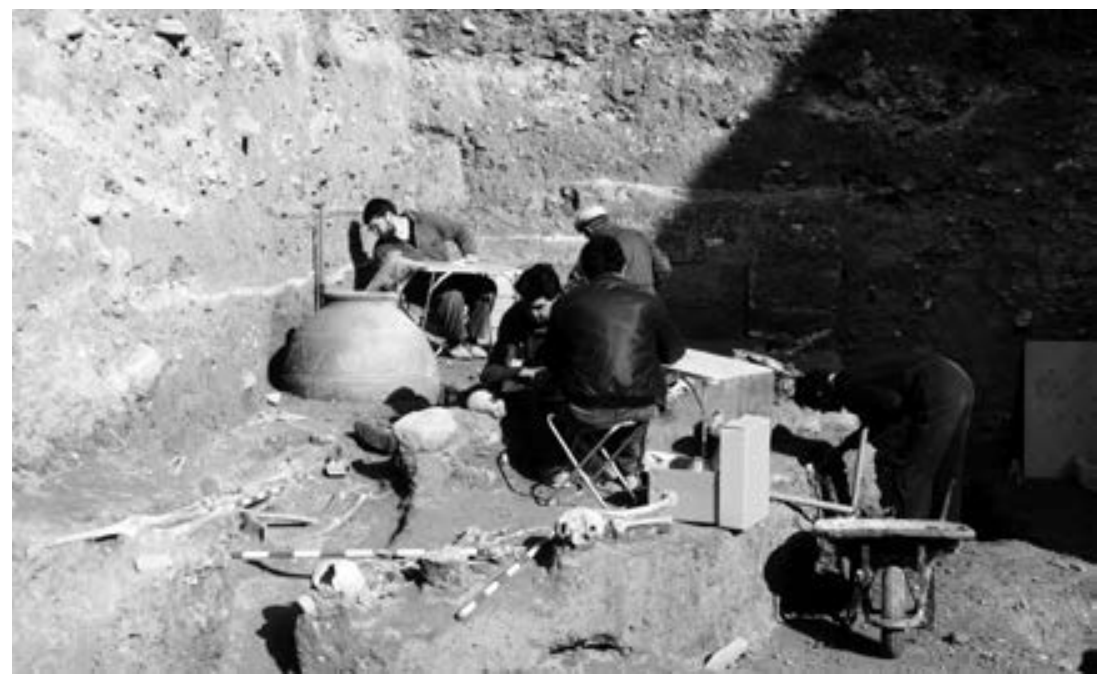

5. Excavación del cementerio islámico. Puede verse la tinaja que recogía el sobrante del almacén de la almazara.

8 El estudio arqueológico del cementerio musulmán puede verse en Galve (1990), 323-325; Galve (1991), 45-46; Galve y Benavente (1991), 87-98; Galve y Benavente (1992), 383-390.

9 Para el resultado de la datación absoluta en los siglos IX y X, cf. Galve y Benavente (1991), 96-97. 


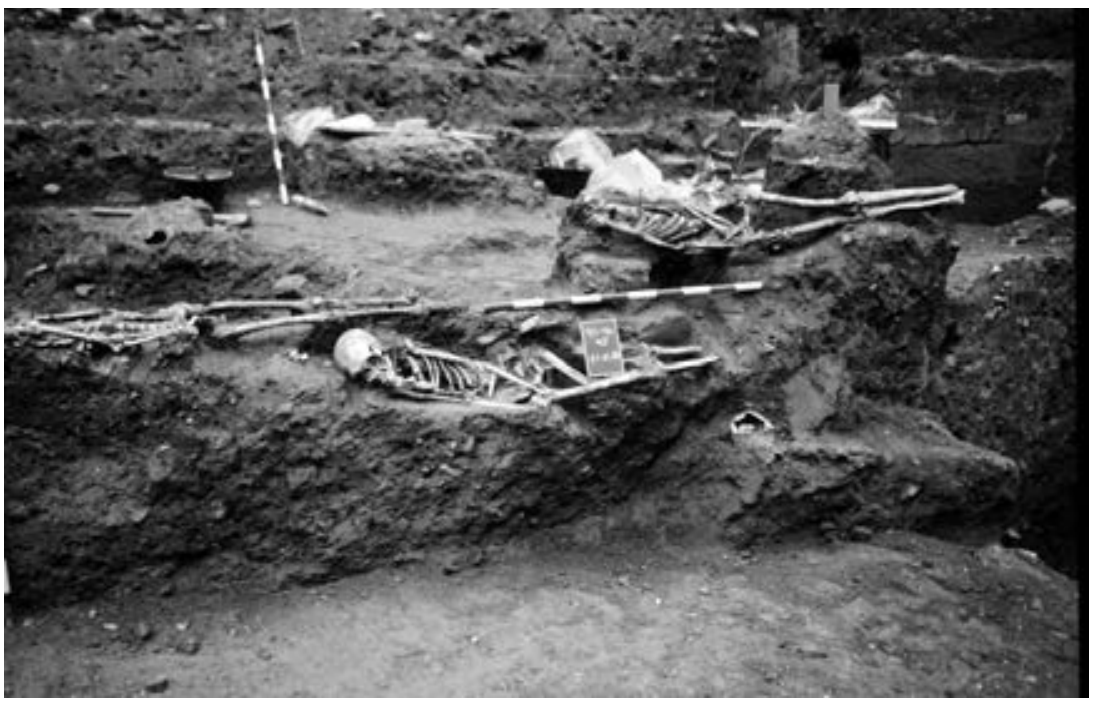

6. Excavación de nivel funerario islámico. Estratigrafía donde se aprecia el suelo de la almazara en el perfil y bajo este las tumbas musulmanas.

Si los enterramientos del cementerio islámico de la puerta de Toledo presentes en estos solares apenas habían sido alterados después, no ocurrió esto con los inhumados con posterioridad, a partir de una época en que deberían considerarse ya probablemente cristianos. Fueron varias las tumbas que, fechadas en un momento tardoantiguo y construidas con lajas de piedra, según pudo verse, se encontraron semidestruidas en una cota sensiblemente superior a las romanas de las que trata este estudio y que, en consecuencia, fueron interrumpidas por las inhumaciones de rito islámico más antiguas. Por su proximidad geográfica (véase la figura 1) habría que adscribir estos enterramientos al área cementerial cristiana de las calles San Blas y Dosset.

Por otra parte, la necrópolis romana de época altoimperial debió de tener inicio tras el abandono de las estructuras domésticas ${ }^{10}$ y de otras que estuvieron a su servicio con anterioridad al final del siglo I: era evidente la anulación de un canal de sección en $U$ en cuyo relleno, formado por adobes

10 La arquitectura correspondientes a la fase de la domus está en estudio por Paula Uribe (Grupo Urbs, Universidad de Zaragoza). 
rotos pertenecientes a los muros de la domus, se excavó la pequeña fosa donde se introdujo una urna cineraria (Incineración II, fig. 23), en este caso en una jarra tapada con un ladrillo recortado. En otro ámbito, en una estancia ya abandonada de la domus, se halló una potente capa de cenizas que posiblemente podría interpretarse como un ustrinum.

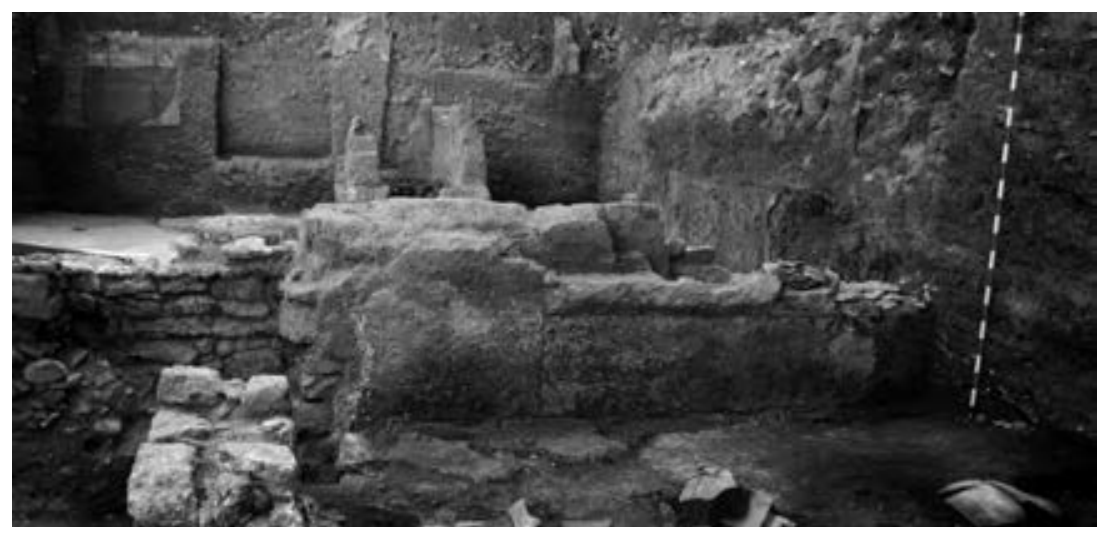

7. En primer término, habitación de la domus del siglo I con pared pintada. Al fondo, el edículo funerario (Inc. I). Puede observarse la potencia alcanzada en el norte del solar.

La excavación del nivel de enterramientos — nos referimos claro está a los individuos cuyo rito fue la inhumación - se llevó a cabo bajo la supervisión de un paleoantropólogo y una restauradora. ${ }^{11} \mathrm{El}$ estado de fragilidad de los restos óseos exigía lentitud y, en muchos casos, consolidación previa a su rescate. Los pasos que se siguieron fueron los siguientes: tras la detección de los restos óseos se procedía a hacer visible todo el individuo para proceder a su limpieza; una vez efectuada esta se llevaba a cabo el dibujo y la fotografía, para después comenzar su extracción. Esta se hacía numerando y describiendo cada uno de los huesos - y si se fraccionaban se trataban de consolidar-, introduciendo cada uno en una bolsa independiente con su etiqueta individual. Durante este proceso se realizaba el registro de datos pertinente y la documentación de los enterramientos. Una vez en el laboratorio de la Sección Municipal de Arqueología se procedía a una limpieza más profunda y, siempre que

11 Ignacio Lorenzo y Teresa Valtueña, respectivamente. 
era necesario, a su consolidación. Finalmente, se trasladaron al Departamento de Paleontología de la Universidad de Zaragoza, donde, mediante un convenio entre esta y el Ayuntamiento, se pretendió realizar el estudio paleoantropológico que nunca llegó a término. Casi veinte años después, un equipo de la Cátedra de Anatomía Humana de la Universidad de Zaragoza ha analizado los restos. El resultado se presenta al final de este trabajo.

A la hora de hablar de la estratigrafía no es exagerado decir que, por fortuna, y sobre todo, el solar de Predicadores, 24-26, ha sido uno de los de mayor potencia estratigráfica de los excavados en la ciudad de Zaragoza. El hecho de carecer casi totalmente de bodegas y de presentar tras el derribo una cota superior en un metro o metro y medio a la de la calzada, fue el factor determinante para este gran espesor, de tal modo que la superposición de tierras y de materiales de los diferentes niveles, interrumpida solamente por pozos y cimentaciones modernas, se ofreció ante nosotros, abusando de la expresión, como las hojas de un libro.

La estratigrafía, de casi cinco metros de espesor, presentaba la siguiente secuencia:

- Nivel a. Superficial, bajo un pavimento de época actual. Relleno de época contemporánea y tierras poco compactas perforadas por zapatas de cimentación. Entre 1,35 y 1,10 m sobre la cota de calzada.

- Nivel $b$. Relleno de época bajomedieval sobre estructuras de tipo industrial (posiblemente una almazara).

- Nivel c. Correspondiente a los enterramientos islámicos. Presentaba restos de adobe de arena de color claro. Tierra arenosa, suelta, poco compacta, con abundantes corpúsculos de yeso. Escasas diferencias de coloración en las diferentes capas: grisácea, rojiza, marrón claro.

- Nivel c1. Se trata del estrato perforado por las tumbas islámicas. De 1 a 1,5 m de espesor. Son tierras de coloración grisácea, más compacta que la de los niveles anteriores; escasos corpúsculos de yeso, cantos de diferente tamaño. Bolsadas frecuentes, de diferente coloración y bien compactadas. En la parte inferior del nivel había una capa de gravas oxidadas, arqueológicamente estériles, que servía de separación con respecto al nivel c2. Este nivel presenta una cronología de época tardoimperial, perforado por algunos enterramientos de los siglos VI-VII. 


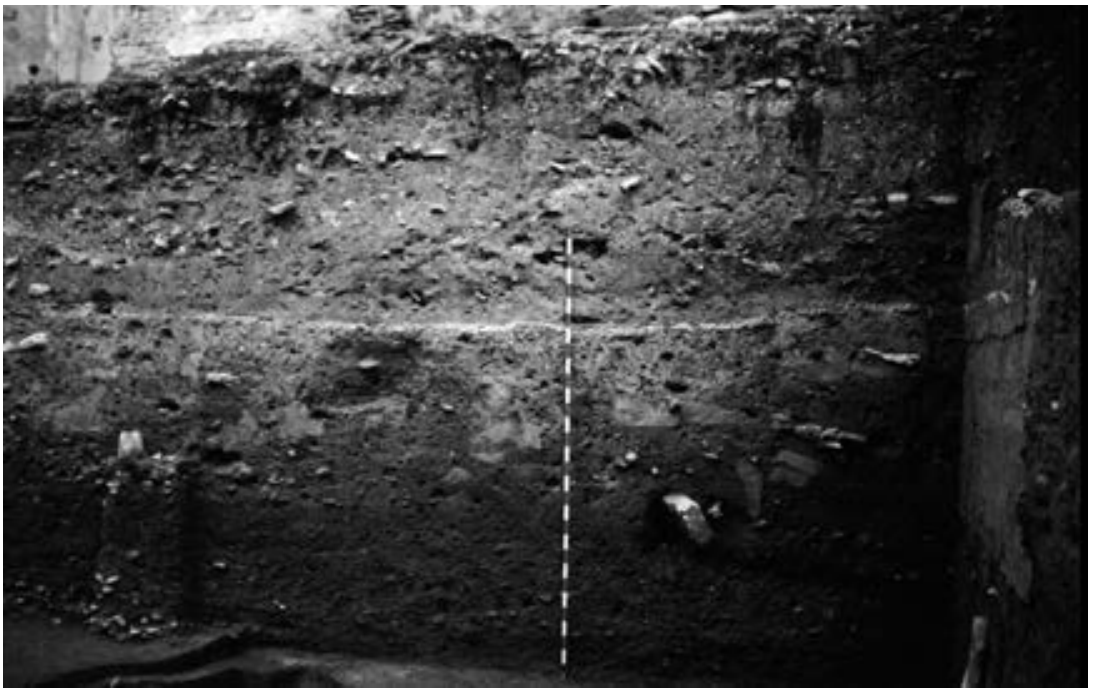

8. Perfil oeste del solar 24-26: línea de suelo de la almazara medieval y bajo ella pequeños túmulos de adobes arenosos, característicos del cementerio islámico. Bajo ellos, a la derecha, tumba de época tardoantigua con lajas de piedras.

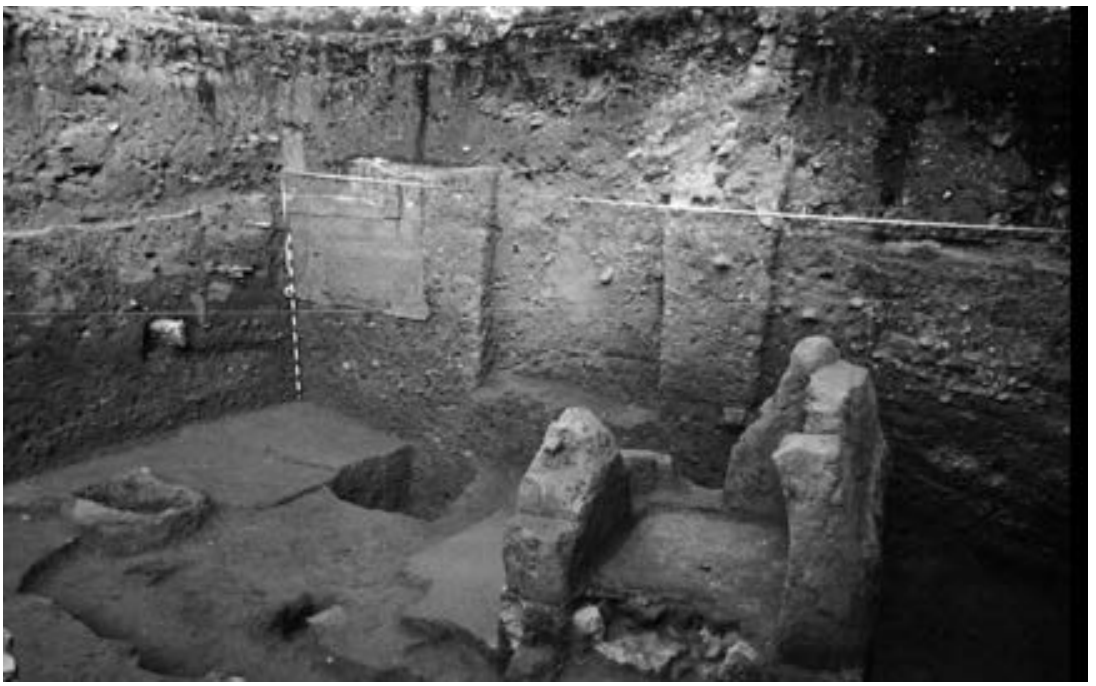

9. Ángulo noroeste del solar. El edículo funerario en primer plano. 
- Nivel c2. De 0,50 m a 1 de espesor. Nivel perforado por los enterramientos de época hispanovisigoda. Tierras de coloración verdosa, sueltas, poco compactas, bien diferenciadas del resto. Parece tratarse de un nivel de relleno de época tardorromana.

- Nivel c3. Constituido por un importante depósito de adobes procedentes del derribo de una de las fachadas de la domus. De un metro de espesor máximo sobre el muro derruido, a $0,40 \mathrm{~m}$ en la zona noreste. Los subniveles $\mathrm{c} 3 \mathrm{a}$ y $\mathrm{c} 3 \mathrm{~b}$ corresponden a niveles de abandono que se datan con probabilidad a principios del siglo II d. de C.

- Nivel c4. Presente tan solo en una zona concreta del solar, se trata de un depósito que ofreció interesantes materiales de época julioclaudia.

- Nivel d. Constituido por arenas finas, compactas, pertenecientes a niveles de inundación sobre las gravas naturales, generalmente sin materiales. En algunos sectores aparece algún fragmento cerámico residual.

Los enterramientos de época romana localizados en la calle Predicadores están constituidos por tres incineraciones y trece inhumaciones, número que podría parecer exiguo para la consideración de lo que entendemos por «necrópolis». En este sentido, reiteramos lo dicho ya acerca del término necrópolis, que es relativamente moderno y que los antiguos jamás lo utilizaron, si bien su frecuente uso se ha hecho ya imprescindible a la hora de hacer referencias a un cementerio amplio y con monumentos funerarios. Sin embargo, y aunque lo conveniente sería reconocer este lugar como un grupo de tumbas a la orilla de una vía, a la salida de la Puerta Occidental de la muralla romana, ${ }^{12}$ su ubicación en un lugar que se perpetuará como zona de cementerio a lo largo de diez siglos, puede permitir el uso del término, teniendo en cuenta que este origen funerario tuvo lugar en la etapa altoimperial como vía funeraria, y que algo más tarde el monumento funerario (bustum) pudo haber constituido un núcleo que sirviera de aglutinamiento a las tumbas que lo rodearon. A ello hay que añadir también la fosa con un équido inhumado. Hay en estos enterramientos unas características comunes en cuanto a la forma y al momento en que se realizó el ritual que hacen posible su consideración de grupo.

12 PP. 157 y ss. 
La principal característica de este conjunto es que todos pueden datarse desde finales del siglo II y a lo largo del III, y que, consecuentemente, estas gentes fueron sepultadas en una época en la que incinerarse e inhumarse eran opciones posibles para estos cesaraugustanos como, por otra parte, sucedía en todo el mundo romanizado. Avala la homogeneidad en la datación el que todo se encuentre en una profundidad similar.

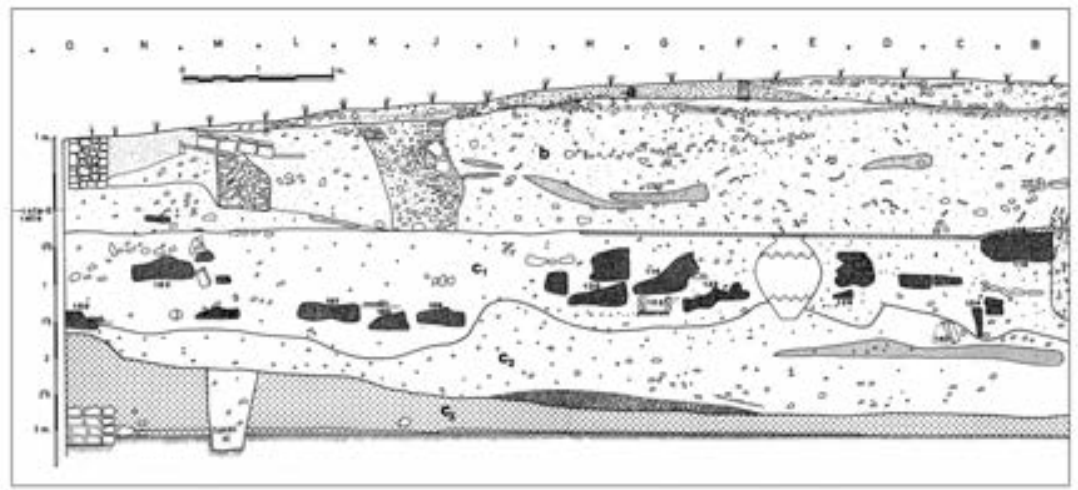

10. Perfil occidental de la excavación (Predicadores, 24-26). Obsérvese un muro de la domus en la parte inferior izquierda y la sección de la Tumba XI, así como la tinaja de la almazara. Los elementos más oscuros son tumbas musulmanas.

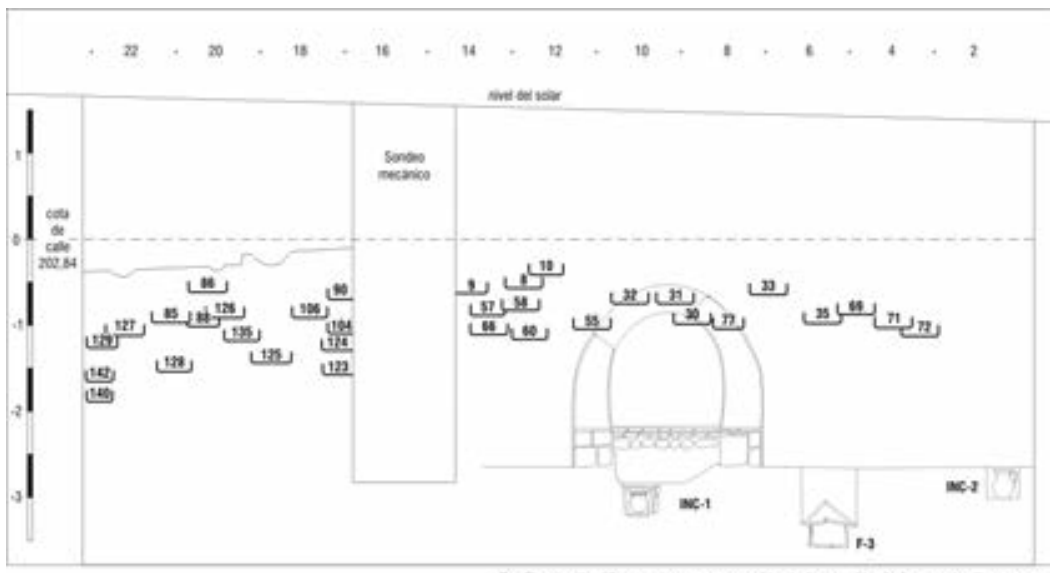

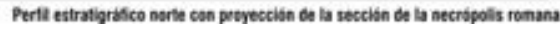

11. Sección del edículo (Incineración I), Tumba III e Incineración II. Las cifras arábigas indican secciones transversales de las fosas islámicas. 


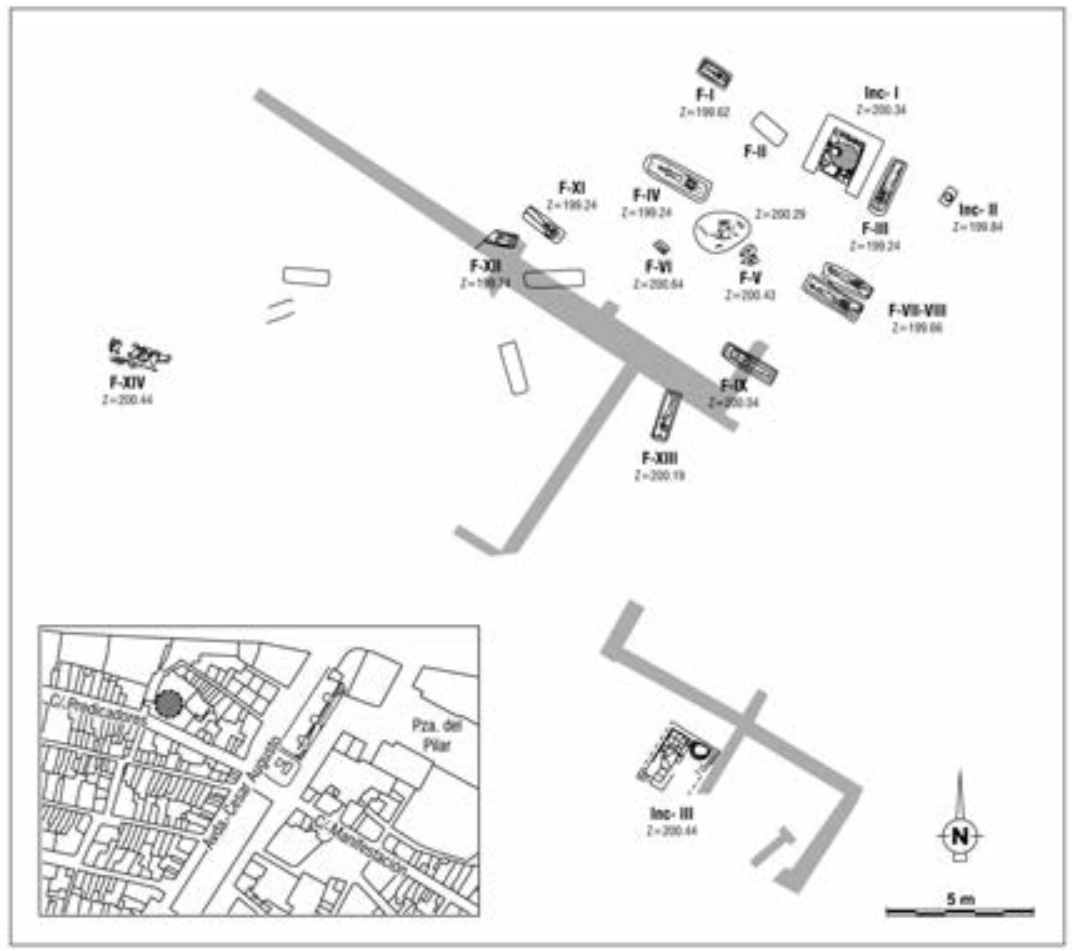

12. Planimetría del grupo de tumbas y su ubicación.

\section{Análisis de las tumbas. Las incineraciones}

La incineración constituyó el ritual favorito de la época altoimperial - hasta tal punto que Tácito, en el siglo I, la consideró romanus mos (Ann. XVII, VI, 2), y calificó la inhumación de Popea de externa consuetudo, en este caso helena-. Por textos escritos son conocidos el procedimiento y la forma de este ritual, entre los que destaca, sin duda, una fuente, Pompeyo Festo (De uerborum significati quae supersunt cum Pauli epitome nn, 32 [bustum] 32. 7-11):

Bustum proprie dicitur locus, in quo mortuus est combustus et sepultus, diciturque bustum, quasi bene ustum; ubi vero combustus quis tantummodo, alibi vero est sepultus, is locus ab urendo ustrina vocatur: sed modo busta sepulcra appellamus. 
Dos de los términos que aparecen en este texto ilustran dos modalidades posibles respecto a la incineración: bustum y ustrina.

El primero de ellos procede de bene ustum ('bien quemado'), y debía hacerse en una superficie protegida por piedras o por un basamento construido al efecto - si es que se tenía intención de erigir un monumento-, o en su defecto, practicar una fosa en la que se amontonaba la madera sobre la que se construía la pira propiamente dicha.

En el caso de tratarse de ustrina, se disponía de un lugar determinado donde solo se realizaba la cremación, recogiendo tras esta operación los restos carbonizados que se inhumaban en otro lugar. ${ }^{13}$

No obstante, la ceremonia debía ser semejante en ambos casos. Sobre la hoguera se colocaba un lectulus o un ferculum de madera que sostenía el cadáver y que se apoyaba en los bordes de la fosa, de forma redonda u ovoide, poco profunda, de manera que después, una vez extinguido el fuego, pudieran recogerse con facilidad las cenizas y demás restos de los objetos arrojados a la hoguera. Los amigos y familiares echaban allí ropas, joyas, alimentos, objetos apreciados por el difunto.

Tras haber realizado el acto de abrir y cerrar los ojos del cadáver (oculus condere) y del beso de despedida, un miembro de la familia que había sido elegido para esta operación, encendía la pira. Los asistentes a la ceremonia arrojaban flores y perfumes y, a medida que iba consumiéndose (rogus), las cenizas, carbón de madera, huesos y ofrendas iban cayendo a la fosa. Cuando la pira tan solo humeaba ya, rociaban agua o vino sobre los restos, se pronunciaba la palabra sacramental ilicet y se profería la expresión tibi sit terra levis, se lavaban los huesos con leche y vino, y se esperaba a que se enfriaran para seleccionarlos. Los huesos sufrían graves alteraciones durante el proceso crematorio, de tal modo que hay serias dificultades con frecuencia incluso para la estimación del sexo (Lange et al., 1987, 17-19), como es el caso del contenido en la urna del monumento funerario de Zaragoza. Desafortunadamente, no han podido extraerse datos informadores del sexo, edad u otros.

13 En la necrópolis galorromana del Champs de l'Image en Argentomagus (Saint-Marcel, Indre) se halló una fosa repleta de cenizas que han sido interpretadas como procedentes de la limpieza del ustrinum (Allain et al., 1992, 112). 
El tratamiento poscrematorio de los huesos no parece que sufriera modificaciones importantes, salvo que eran siempre cuidadosamente lavados y separados del resto de la pira antes de ser depositados en el fondo de la fosa o en los recipientes. ${ }^{14}$

Una vez recogidos se procedía a introducirlos en la urna o cualquier otro recipiente para proceder a su enterramiento, cubriendo con tierras la incineración, al igual que sucedía en la inhumación, mediante la ceremonia tradicional romana de la congestio terrarum. En Angera (Italia) los objetos se encontraban dispuestos dentro del área carbonosa, con cierta tendencia a concentrarse en el centro, raramente custodiados por alguna protección lígnea o latericia; la moneda (naulum) destinada a Caronte, se encontraba solitaria en un ángulo de la fosa (Senna Giesa, 1985, 55). También la moneda del bustum de Zaragoza se encontraba entre las cenizas (pág. 37).

Otra práctica funeraria tradicional estaba constituida por el os resectum, considerada una pervivencia de la inhumación. ${ }^{15}$ Finalmente, cabe destacar que el ritual de la incineración no fue aplicado a los recién nacidos, sino que estos eran inhumados (pp. 155-157). Con anterioridad al siglo II, es decir, en una época en la que la incineración era la forma habitual, la inhumación era practicada con los niños, y personas apaleadas por la multitud o aquellas a las que su convicción religiosa prohibía el fuego, como era el caso de los pitagóricos (Toynbee, 1971, 38; Nock, 1932, 336).

Las cremaciones de la necrópolis occidental que aquí se tratan no son las únicas halladas en esta ciudad: en la necrópolis oriental se hallaron diecisiete urnas que contenían cenizas y junto a ellas objetos usados en el ceremonial funerario (Aguarod, 1991a, 23). Ambos hallazgos son los únicos que se han dado a conocer hasta ahora a partir de las excavaciones.

14 Esto se ha podido observar en esta necrópolis del siglo I, donde se excavaron un centenar de incineraciones datadas desde época de Claudio a comienzos del periodo Antonino (Hosdez, Jacques, 1989, 11). Sirve también al respecto por su minuciosidad la obra de G. Senna Giesa (1985) sobre el cementerio de Angera, donde predomina la incineración directa (Bustumgrab, Doorselaer, 1967, 87, y para el tipo E, 106).

$15 \ll[\ldots]$ los familiares recogían en una tela blanca los huesos calcinados, enterraban un dedo cortado previamente al cadáver — os resectum - para dar satisfacción a la antigua costumbre inhumatoria - iusta facere-, cumplían el sacrificio de la "liberación de la muerte" - feriae denicales - y asistían al banquete funerario» (Bayet, 1984, 82-83). 
La incineración en Predicadores se encuentra representada en un exiguo número de hallazgos — dos en realidad, y uno posible — que no resta valor a este rito funerario, si atendemos a varias razones. En primer lugar, cada uno de los ejemplos corresponde a una tipología diferente, tratándose de un bustum con monumento (Inc. I), una fosa con una jarra-urna en su interior (Inc. II) y otra estructura que muy posiblemente debió tratarse de otro monumento (Inc. III). Las incineraciones I y II parecen ser coetáneas, datando de finales del siglo II o principios del III, mientras que la Inc. III, que está un tanto alejada de las otras y es muy probable que estuviera muy próxima a la vía, carece de datación precisa, dado el estado en el que se encontró, aunque por su situación estratigráfica puede considerarse posterior a principios del siglo II.

Otra consideración de importancia es el fenómeno de la proximidad cronológica de las cremaciones I y II con todas las tumbas de inhumación, hecho comprobado por las características estratigráficas y tipológicas que presentaban. Esta contemporaneidad debe entenderse como relativa a un periodo de unos cincuenta años, no a un momento concreto para todas las tumbas, entre las que todas parecen ser coetáneas.

\section{Incineración I (bustum con aedicula) ${ }^{16}$}

Cubierta por el único monumento funerario completo hallado en Caesaraugusta, la fosa que guardaba la urna estaba sellada todavía. Tras desmontar las diversas capas de ladrillos (suelo del interior del monumento), y a 0,66 m de la cota de la capa exterior de la edícula, entre tierras cenicientas, apareció un fragmento de tegula cuadrangular, y bajo esta, otra más. Ambas piezas cerámicas hacían función de tapadera de la olla que guardaba las cenizas. Seguramente, debido a la presión de los estratos superiores, la vasija tenía la parte del borde roto, pero se conservaron todos los fragmentos, de tal modo que hoy, tras su restauración puede contemplarse la pieza entera. Los restos de la incineración del cadáver estaban completamente limpios, debido seguramente a que la vasija que hizo de urna quedó herméticamente cerrada por los ladrillos planos que depositaron para cerrarla. Resulta curioso el hecho de que en un enterramiento con monumento y edícula, en torno al que, a juzgar por el depósito funerario como se verá, debieron observarse las ceremonias rituales con rigurosidad, la urna (olla) fuera tan modesta y ni siquiera dispusiera de una tapadera al uso.

16 Dado que el monumento que cubría el bustum se trata más adelante, en el apartado que ahora nos ocupa solo va hacerse referencia a la urna cineraria y al depósito funerario. 


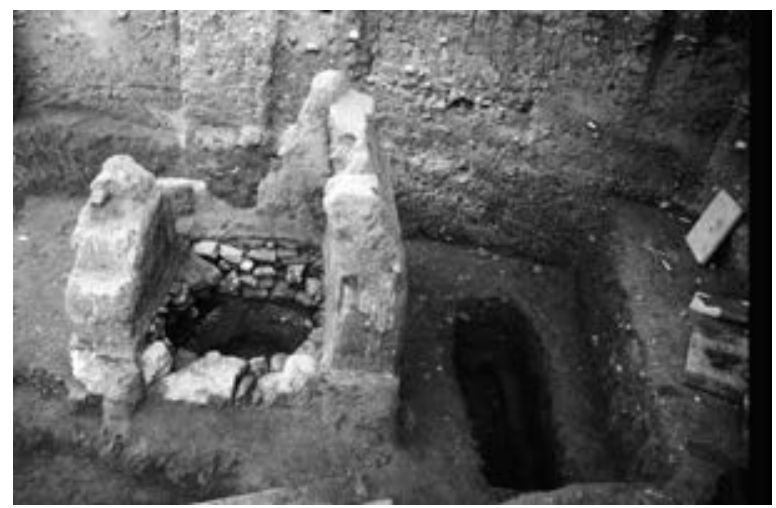

13. El mausoleo ya excavado (Inc. I) y la fosa de la Tumba III. La ubicación de ambas estructuras indica que el bustum se realizó en primer lugar y que la inhumación se acomodó a este.

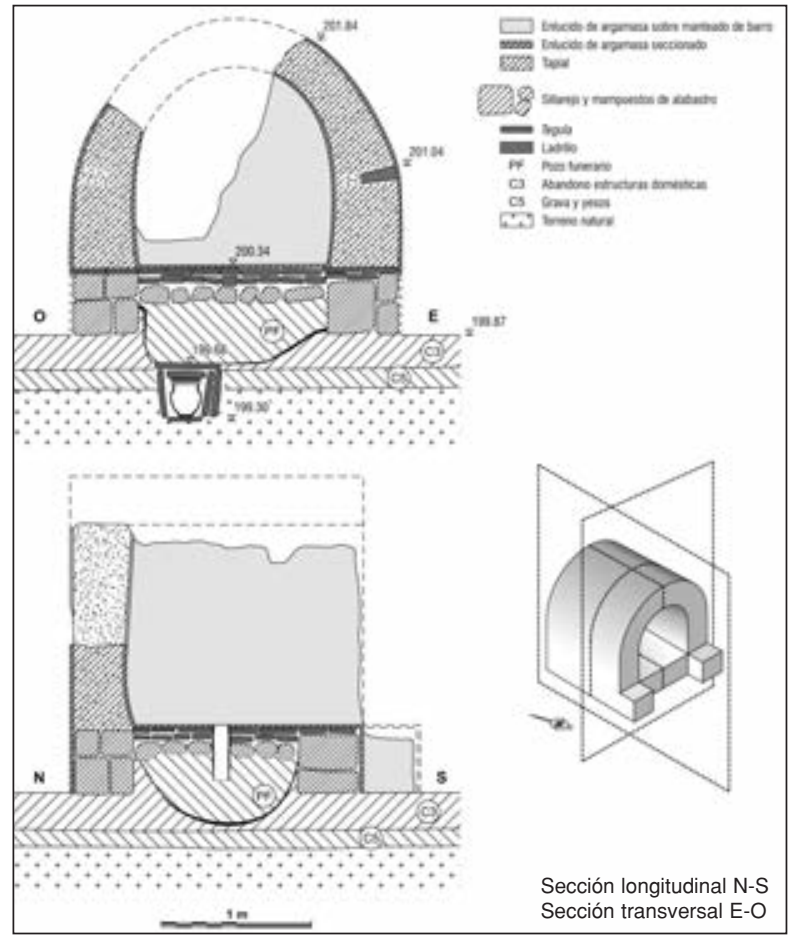

14. Incineración I: bustum con aedicula. 


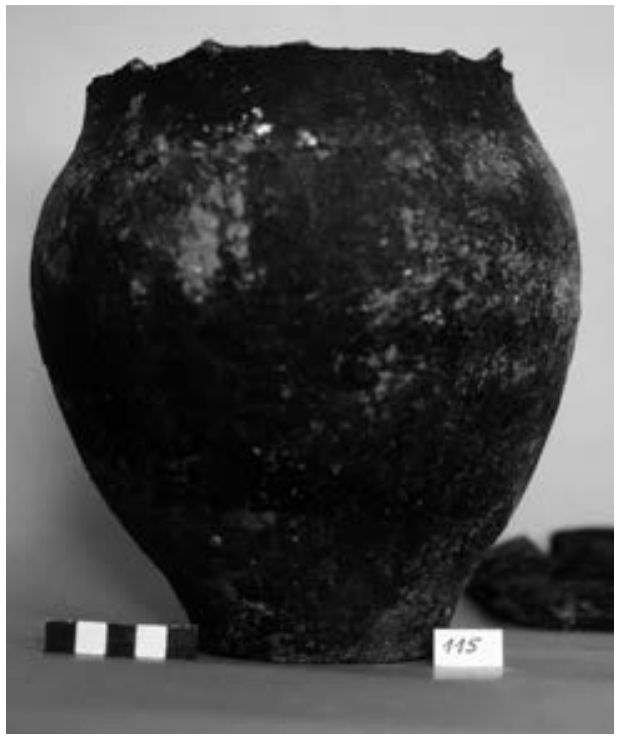

15. La urna todavía sucia de las tierras cenicientas de la pira funeraria.

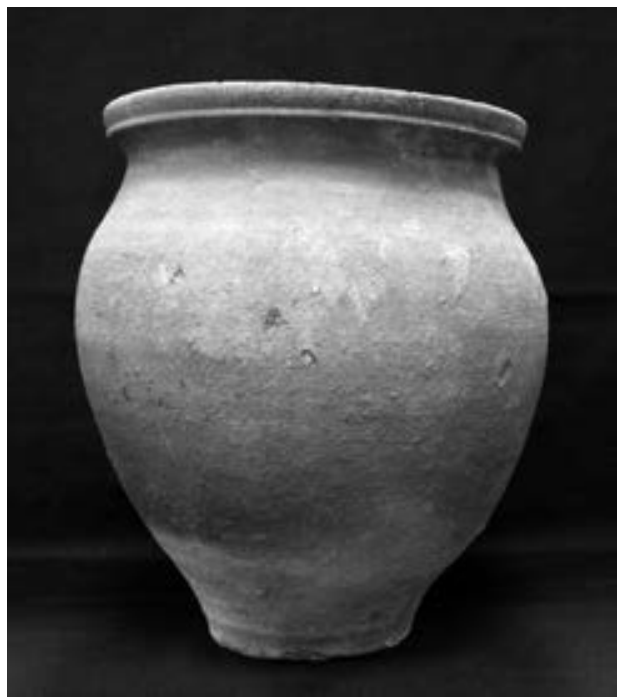

16. La misma urna una vez restaurada. 


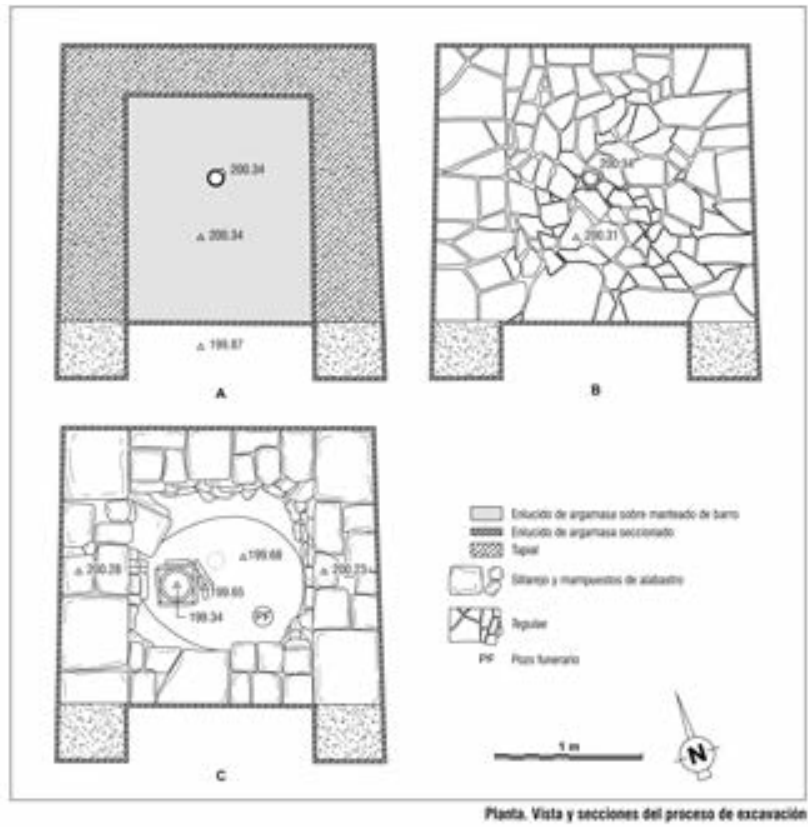

17. Incineración I: bustum con aedicula.

El recipiente que contenía las cenizas había sido introducido en una especie de caja hecha de ladrillos, a modo de cista, en la que se depositó y cuyo espacio estuvo destinado exclusivamente para este fin. Así, se formaba con un ladrillo plano en el fondo, otros cuatro laterales y, por último, con el superior.

El enterramiento estaba descentrado con respecto a la planta de la estructura, colocado en la parte occidental, mientras que el canalículo que hacía de dispositivo para las libaciones se situaba en el centro y llegaba a la profundidad de la parte superior de la urna. ${ }^{17}$

Como se ha dicho, ha sido imposible determinar el sexo, edad ni otros datos (vid. la p. 250).

17 Véase tratamiento del monumento en las pp. 87 y ss. 


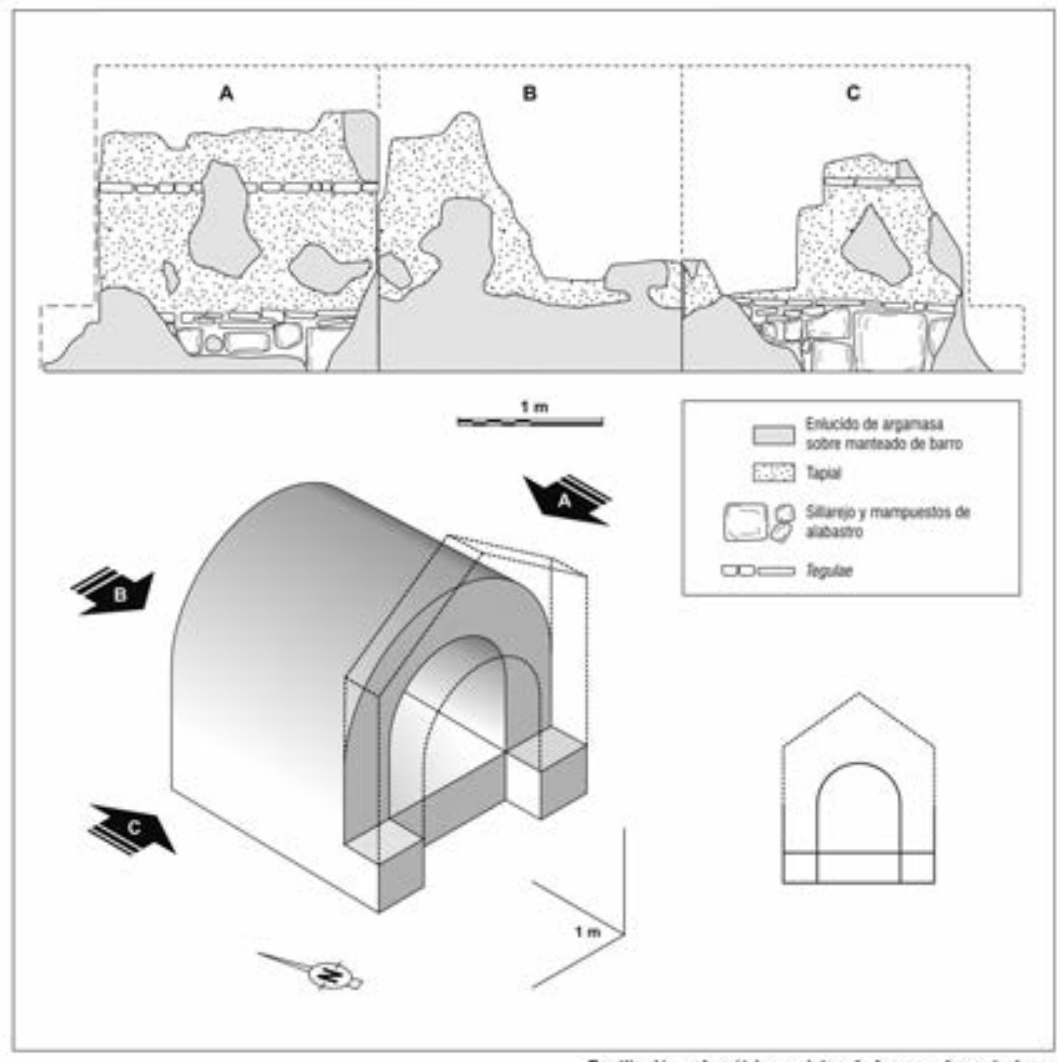

Restitucion volumetrica y vistas de las paredes erterioges

18. Incineración I: bustum con aedicula.

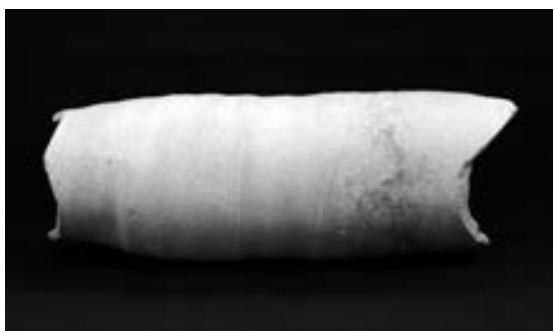

19. Tubo cerámico utilizado en el bustum para comunicar con el interior de la tumba. 


\section{Depósito funerario}

Constituye un conjunto interesante por tratarse de lo habitual en las ceremonias fúnebres romanas y por el estado de fragmentación de varias de las piezas cerámicas, fenómeno que se trata más adelante. Todos los objetos que se citan a continuación se hallaron en el pozo funerario y estaban sellados por el monumento que se construyó encima.

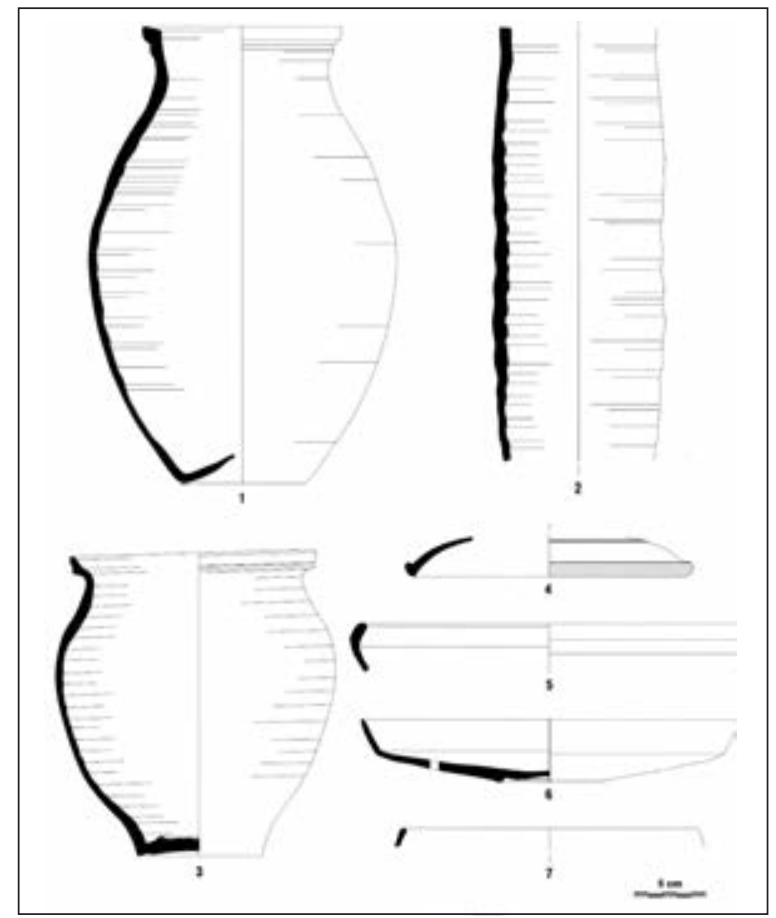

20. Ajuar cerámico del bustum (Incineración I).

1. Jarra grande. Sigla: 87.66/ 41.464 .

Las dimensiones de este gran envase son $14,2 \mathrm{~cm}$ de diámetro en el borde, $22,2 \mathrm{~cm}$ en el cuerpo, $9 \mathrm{~cm}$ de base y una altura de $32,8 \mathrm{~cm}$. La pasta presenta desgrasante de grano fino con algo de mica. Vacuolas aisladas de pequeño tamaño. El color externo es ocre. 
Se trata de una jarra-tinaja de cuerpo elíptico alargado, con fondo umbilicado y borde recto bimoldurado, levemente inclinado hacia el exterior; la moldura superior aparece engrosada a modo de labio cuadrangular apuntado. El cuello no se encuentra diferenciado e, igualmente, no presenta rebaje interno. Conserva las improntas de un asa única, que nace directamente debajo del borde para reposar en el hombro de la vasija en su zona más saliente. La pieza ofrece numerosas huellas pertenecientes al alisado externo, algunas irregulares, provocando ligeras escoriaciones de la superficie.

Apareció fragmentada en 165 piezas que sufrieron diferente grado de daño con la combustión de la pira funeraria. Consecuencia de este hecho son las coloraciones diferenciadas: desde el color ocre de la vasija hasta tonalidades grisáceo-verdosas, casi negruzcas en algunos pedazos. La rotura se encuentra en forma de grandes piezas, luego rotas otra vez en otras más pequeñas, quizá por haber sido tirada al suelo, ${ }^{18}$ habiéndoseles ocasionado un perfil redondeado y presentando diferente coloración causada por su mayor o menor exposición al fuego. Se localizó a 0,66 m del fondo del pozo de cenizas.

\section{Conducto de cerámica (canalículo para libaciones). Sigla: 87.66/ 41.488.}

Dimensiones: el diámetro máximo es de $12,2 \mathrm{~cm}$. La altura máxima conservada $32,8 \mathrm{~cm}^{19}$

El color de la pasta es ocre y tiene desgrasante de tamaño fino y medio, en color blanco, negro, gris oscuro y micáceo, para aumentar la impermeabilidad y reducir la porosidad. Tiene algunas vacuolas. Su superficie está sin alisar, observándose con claridad el sentido ascendente de las digitaciones para su elaboración.

3. Olla (urna cineraria). Sigla: $87.66 / 41.489$.

Dimensiones: altura: $21,8 \mathrm{~cm}$. Diámetro en el borde $17,5 \mathrm{~cm}$, en el cuerpo 20,4 cm y en la base $9 \mathrm{~cm}$.

La pasta es de cocción reductora y su color externo es grisáceo. Contiene desgrasante de tamaño fino y medio, en color gris, negro y blanco (en menor cantidad), junto a una abundancia relativa de mica; presenta algunas vacuolas.

18 Véanse las pp. 152-154 donde se considera la posibilidad de rotura intencionada ritual.

19 Por sus dimensiones similares, Adam (1984), 285. Para testimonio de tubuli en Caesaraugusta, Galve et al. (2007), 170-171. 
Se trata de una olla de cuerpo ovoide, con fondo plano levemente levantado al interior, y borde recto bimoldurado algo inclinado hacia el exterior (la moldura inferior aparece a modo de pequeño listel, algo apuntado o remarcado) con rebaje interno para recibir tapadera; el cuello aparece estrangulado. La superficie interna se presenta sin alisar, como es propio de este tipo de recipientes de cocina. El fondo no presenta huellas del cordón como consecuencia de su rehundido, pero aparece agrietado por una mala hidratación de esta zona. No tiene rastro de un posible uso culinario; en cambio, presenta huellas del apilado dentro del horno en el tercio inferior de su superficie (Aguarod, 1991b).

4. Tapadera Forma Ostia I, 262 (cerámica africana de cocina). Sigla: 87.66/ 41.405. Hallada entre las dos primeras capas de suelo de tegulae de la aedicula.

Dimensiones: diámetro del borde $20,2 \mathrm{~cm}$, altura $3,3 \mathrm{~cm}$.

Se trata de una pieza de perfil semicircular y borde engrosado a modo de labio circular. Como toda decoración presenta dos finos surcos en la zona superior, próxima a la parte del posible pomo, que no se ha conservado. La característica pátina cenicienta de estas piezas únicamente recubre la zona del borde.

Cronología: se trata de la Forma Ostia I, 262 (Aguarod, 1991c, 254255, fig. 3; Hayes, 1972, 208), fechada desde mediados del siglo II a comienzos del siglo V, ampliamente difundida por esta zona del valle del Ebro. Es equivalente a la Forma Hayes 195, asimilada a la 182 (Hayes, 1972, 201-203, fig. 35) fechada desde mediados del siglo II a mediados del III, de igual modo que la Forma Hayes 181 (Hayes, 1972, 260, fig. 1) y equivalente a la Forma Lamboglia 9 A (Aguarod, 1991c, 260-261, fig. 105-1).

5. Cuenco invasado. Sigla: $87.66 / 41.407$ y 41.409.

Dimensiones: diámetro del borde $27 \mathrm{~cm}$ y del cuerpo $28 \mathrm{~cm}$.

Se trata de un cuenco hemiesférico con borde vuelto hacia el interior, ligeramente engrosado. En la zona de unión con la panza presenta un ligero rehundido, a modo de surco, como toda decoración. La superficie se encuentra alisada.

6. Plato Hayes 18 (Sigillata Africana Clara A). Sigla: 87.66/ 41.467. A una profundidad de $0,66 \mathrm{~m}$ del suelo del pozo funerario.

Dimensiones: diámetro en el borde $26,4 \mathrm{~cm}$, en la carena $24,4 \mathrm{~cm}$ y en la base $7,6 \mathrm{~cm}$; la altura es de $4,6 \mathrm{~cm}$. 
La pasta es de color rojizo y su revestimiento también. El desgrasante presenta escasa cantidad de puntitos de color blanco y escasa mica. Se trata de un plato carenado de paredes rectas y borde igualmente recto, abierto hacia el exterior. El fondo presenta un pie anular muy bajo, algo levantado hacia el interior y con surco interno.

Apareció fragmentado de la misma forma que la jarra-tinaja (lám. IV-1) hallada en el mismo contexto, en grandes fragmentos y luego desmenuzados en otros más pequeños. Debió romperse al tirarse al suelo y caer sobre la zona del borde, sobre uno de sus laterales, tal y como se observa en la rotura diferenciada con el resto (esquirlados o fragmentados más regularmente) y con huellas de escoriaciones. Una tercera parte del recorrido de su borde-carena aparece con el color original de la pieza cerámica, a diferencia de las restantes, que oscilan desde el grisáceo o marrón oscuro-achocolatado, en ocasiones fuertemente ahumados.

Cronología: se corresponde con la Forma Africana Clara A, Hayes 18 (= Salomonson A 20), fechada a comienzos del siglo III (Hayes, 1972, 43, fig. 6) e igualmente se relaciona con la Forma Lamboglia 3c (= Hayes 16), fechada en la segunda mitad del siglo II (Hayes, 1972, 41-42, fig. 6).

7. Fragmento de cuenco. Sigla: 87.66/41.404. Borde ligeramente invasado de cerámica con engobe rojizo.

Moneda de bronce. Dinastía Antonina. Sigla: 87.66/ 40.906. N. ${ }^{\circ} 46$ del Monetario del Ayuntamiento. Con muestras de haber sufrido el fuego directamente, es imposible determinar de qué personaje en concreto se trata, aunque es una cabeza masculina.

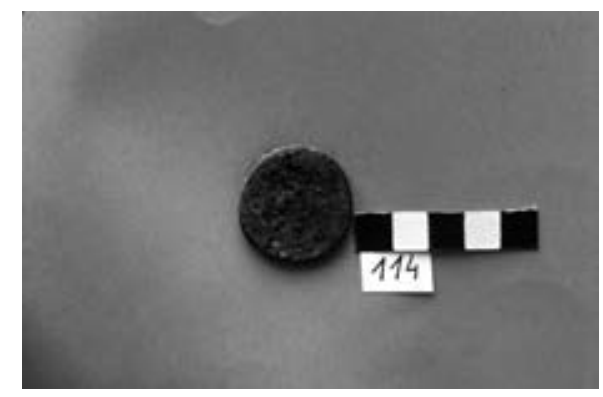

21. Incineración I (bustum). Moneda de época antonina. 


\section{Cronología del depósito funerario del bustum}

Los materiales recuperados en el interior del monumento eran de origen y función heterogéneos, reduciéndose a dos las piezas que proporcionan una aproximación a la cronología del monumento, ya que las formas comunes corresponden a piezas ampliamente divulgadas por el valle medio del Ebro y están provistas de una amplia cronología. Así, las vasijas más interesantes al respecto se reducen a las siguientes: el plato Forma Hayes 18 de Sigillata Clara A y la tapadera Forma Ostia I, 262 de cerámica africana de cocina. La datación de la última pieza se ubica en un intervalo que oscila entre los años centrales de la segunda centuria hasta los primeros años del siglo V: no obstante, la construcción del monumento funerario se podría situar en los principios del siglo III gracias a la cronología de la vasija norteafricana. ${ }^{20}$

\section{Incineración II (lám. V)}

Se trataba de una incineración introducida en una jarra de cerámica común y cubierta con un ladrillo cuadrado. El enterramiento se halló al limpiar un corte estratigráfico, y su excavación fue incompleta porque estaba bajo el medianil de un edificio y hubo que perforar dicho corte para extraerlo. No obstante, para su inhumación se había practicado una fosa, al igual que en el resto de los enterramientos, en el nivel c3 - nivel formado por la acumulación de material constructivo causado por el desplome de una fachada de adobes de la casa-.

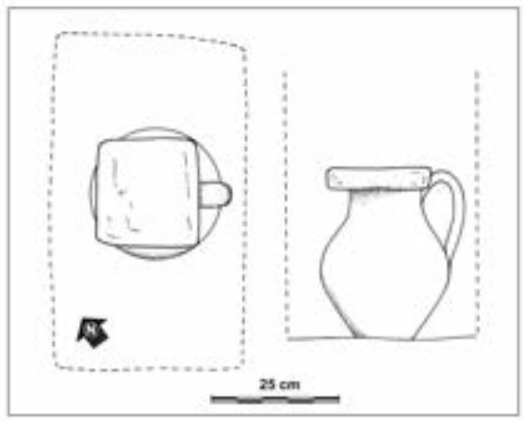

22. Incineración II.

20 Agradecemos a J. Escribano la colaboración en el estudio del contexto cerámico del bustum. 
La urna estaba sobre la parte superior de un canal de sección en U, seguramente perteneciente a la citada casa de época fundacional. Por hallarse en el corte de la excavación e introducirse en el terreno del solar adjunto, no se pudo estudiar como hubiera sido deseable.

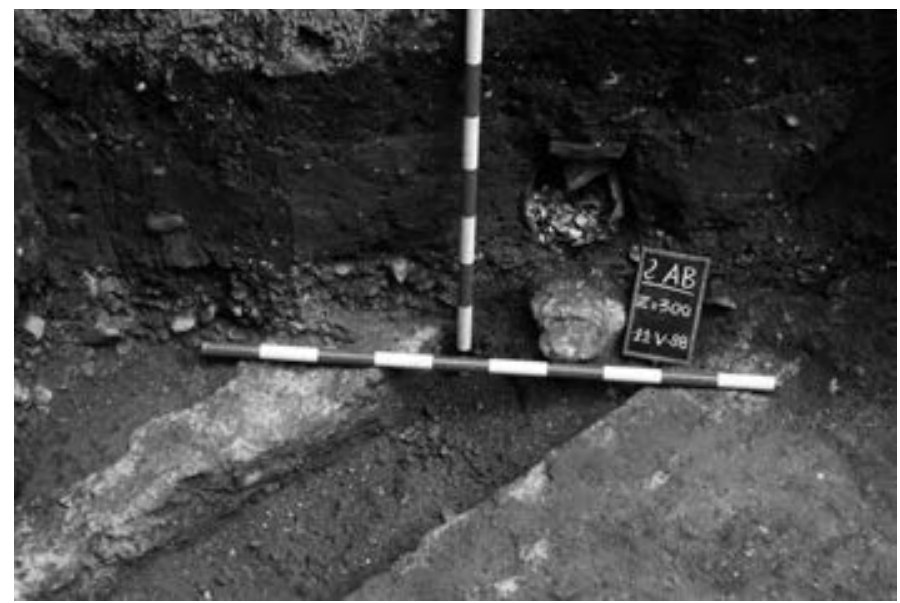

23. Incineración II. La fosa se practicó en el relleno de abandono de un canal de uso doméstico que debió de anularse al mismo tiempo que la domus.

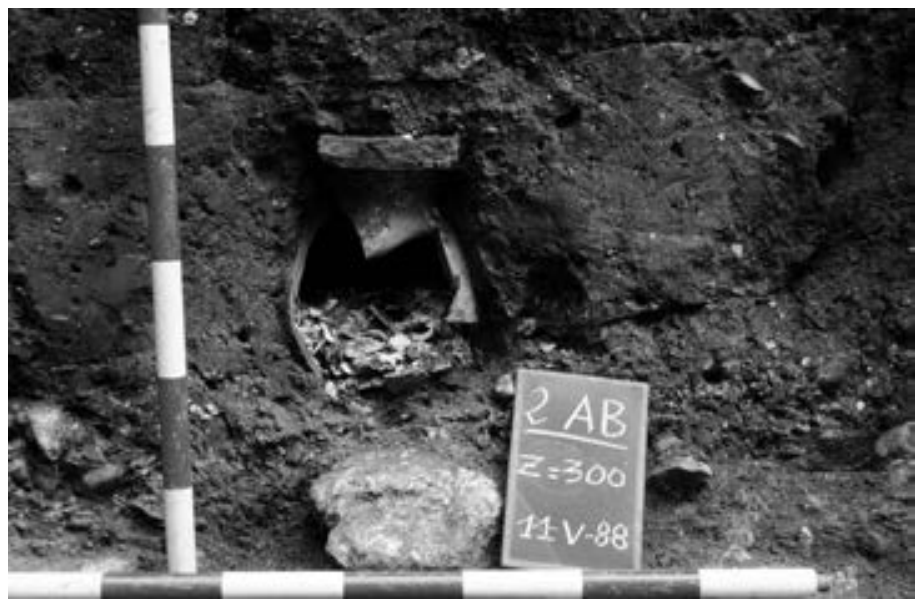

24. Incineración II. Jarra con las cenizas en su interior. 
El uso de la jarra como urna cineraria aparece, por ejemplo, en la necrópolis francesa de Vatteville-la-Rue (valle del Sena), y se ha considerado como criterio de antigüedad, habiéndose contabilizado un $82 \%$ de estos recipientes en los siglos I y II, y un $34 \%$ en el siglo III (Lequoy, 1991, 231). La ubicación de este recipiente proporcionaba una cota similar a la urna del bustum y tanto este dato como su proximidad parecen sugerir coetaneidad (véase la fig. 11, p.25).

\section{Incineración III}

Es posible que se tratara en este caso de un pequeño monumento funerario, o parte de otro mayor, formado por, al menos, tres restos estructurales, si bien su estado de conservación - debido al grado de destrucción que presentaba - no permitía una interpretación segura. Parece que tuvo forma cuadrangular, construido por estrechos tabiques de argamasa y piedra que, además de rodearlo por el exterior, compartimentaban unos espacios diferenciados. No es seguro que se trate de una incineración, aunque parece lo más probable debido a la existencia de un pozo ennegrecido con cenizas que guardaba en su interior restos de un ánfora africana. Podría también haberse tratado de un bustum.

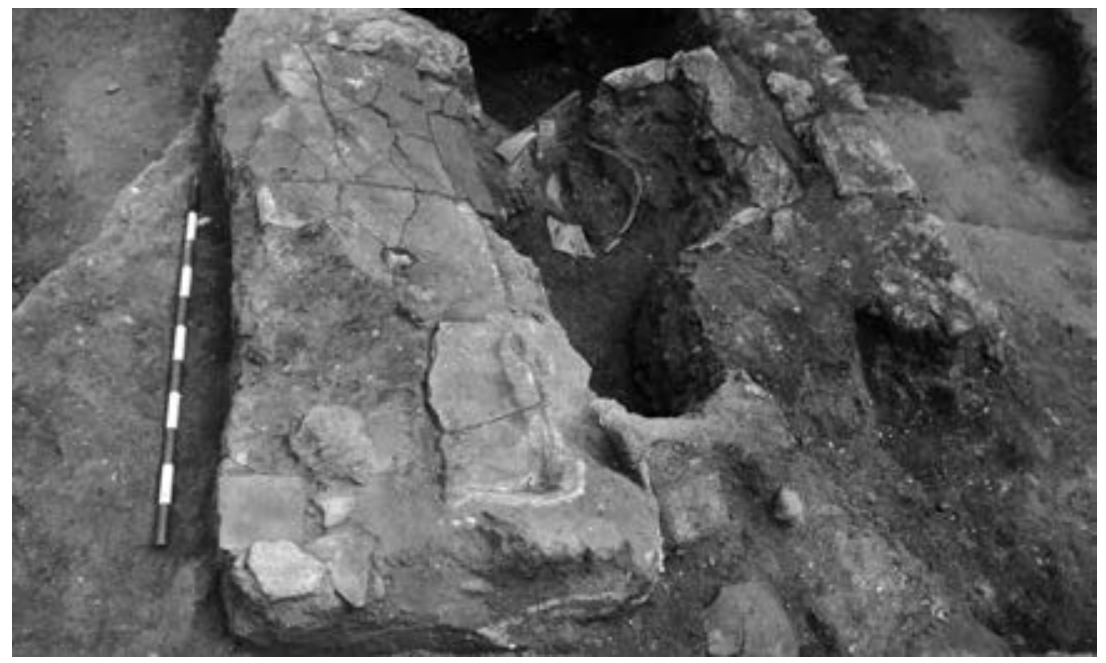

25. Vista de la estructura funeraria desde el sur. Debió estar muy próxima a la orilla de la calzada romana (Predicadores, 20-22). 


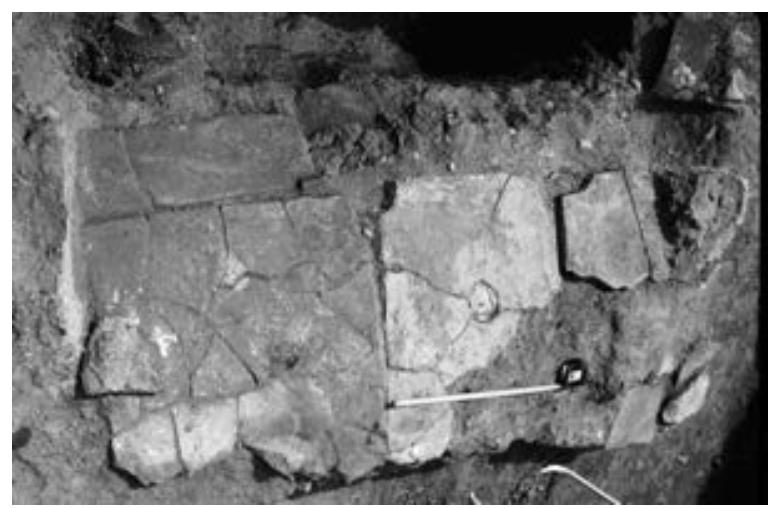

26. Parte de la estructura funeraria vista desde el este. Tegula con perforación circular en el centro.

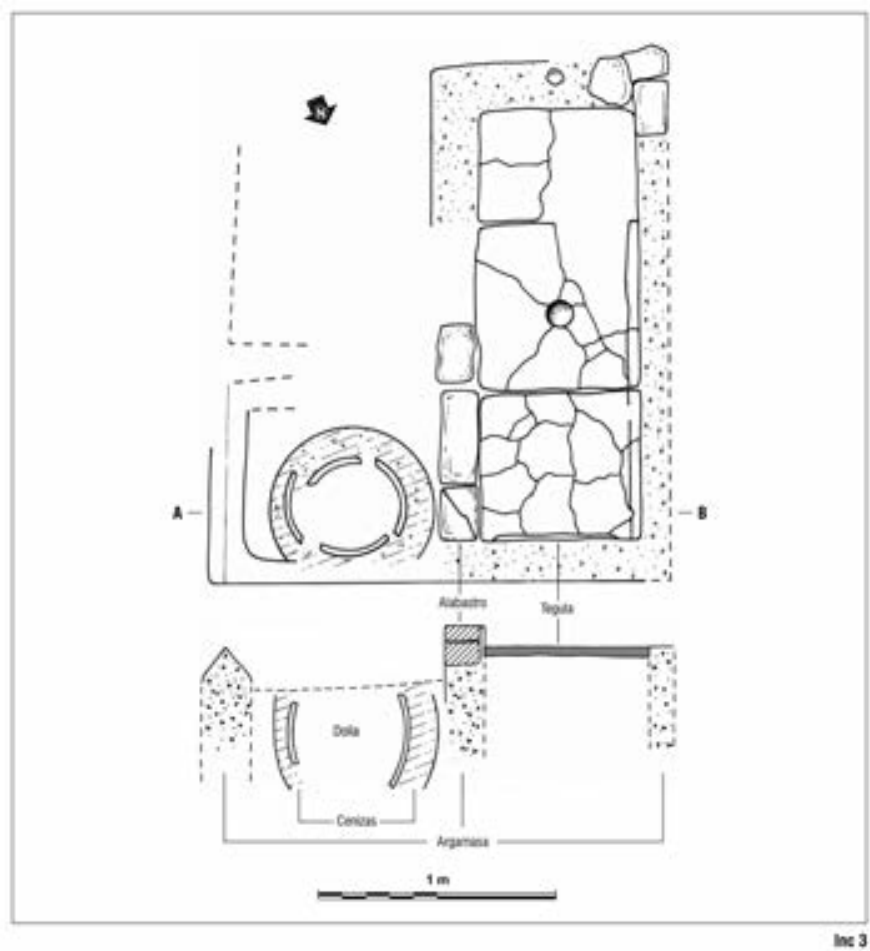

27. Incineración III. 
La mitad de la estructura estaba compuesta de tres tegulae y la central tenía una perforación circular. Estas dos características citadas, dimensiones y agujero central, parecían indicar una sepultura; sin embargo, bajo ellas no había nada. Hay que indicar que el agujero, que podría suponerse para la ceremonia de las libaciones, estaba sellado con cal formando una especie de tapón. Esta circunstancia parece apuntar que se tratara de la parte inferior de una estructura funeraria. La dimensión del conjunto de las tres tegulae más el murete de argamasa era de 2,20 m, en dirección N-S, mientras que el lado E-W medía $1,90 \mathrm{~m}$.

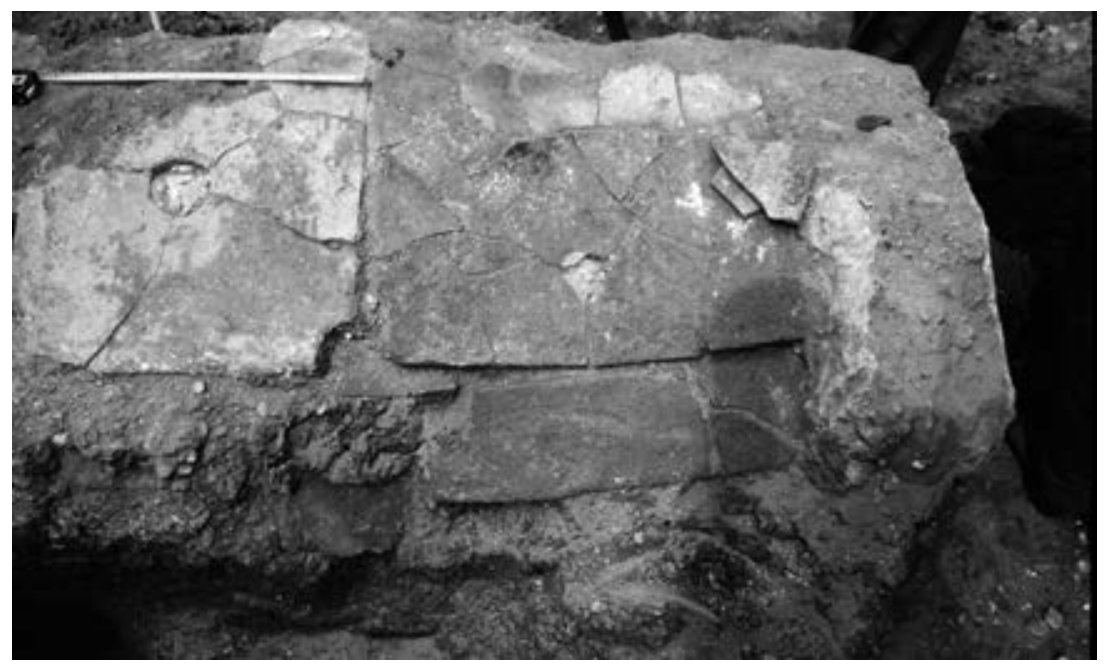

28. Incineración III. Tegulae y albañilería.

Otro de los elementos de esta compartimentación estaba constituido por un espacio cuadrado cuyo muro NW, construido en argamasa, tenía en la parte superior sección apuntada. En el interior apareció el pozo que hemos interpretado como funerario, ya que contenía en su interior huellas y restos de combustión, así como un envase grande incompleto que debió de guardar la urna que fue extraída en algún momento posterior. En el contexto salieron cenizas y algunos huesos animales calcinados, además de los objetos que se citan. 


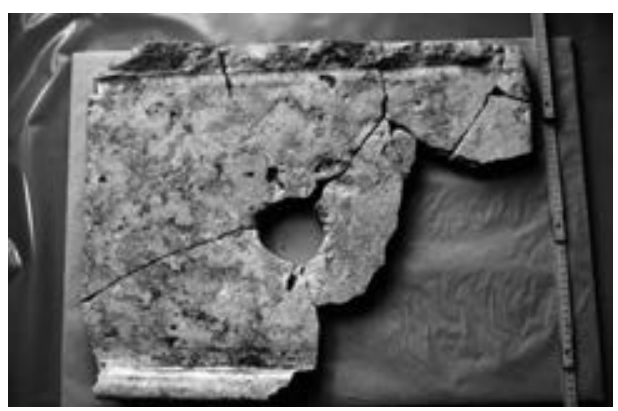

29. La tegula que presentaba el orificio central.

Las dudas acerca de esta estructura radican en haberse encontrado vacía de restos humanos. No obstante, podemos remitir a un posible paralelo tipológico: en el sector norte de la necrópolis de Carmona (Sevilla) una incineración cubierta por tres tegulae y con dispositivo de libaciones. ${ }^{21}$

Puede, con las reservas necesarias, apuntarse la posibilidad de que se tratara, como ya hemos dicho, de parte de un monumento funerario situado en la orilla de la vía cuyo trazado es muy probable que perdure en la actual calle Predicadores, al menos en su primer tramo.

La estructura funeraria se construyó sobre un nivel de cronología posneroniana y podría situarse a partir del último tercio del siglo I d. de C., tras el abandono de la domus de época fundacional, es decir, en una época temprana si la comparamos con el resto de los enterramientos de la zona. Sin embargo, no ha de extrañar este hecho, ya que su ubicación estaría muy próxima a la orilla de la vía, tratándose de la estructura funeraria más exterior del conjunto estudiado.

21 Belén et al. (1986), p. 58. Todas las sepulturas de este sector norte de la necrópolis de Carmona guardan similitudes en cuanto a las características del ritual funerario. En el extremo oriental suelen presentar un tubo de cerámica, de los que se utilizan en la construcción para conducción de aguas, similar al de nuestro bustum, vid. la lám. 19 que serviría de conducto para la ceremonia de las libaciones. En la tumba que aparece en la figura 5.2, se ha prescindido de este tubo, pero el rito parece ser el mismo, ya que una de las tres tegulae de la cubierta presentaba una perforación circular y había otro ejemplar de este tipo en la necrópolis oeste que se conocía desde las excavaciones antiguas (Rada y Delgado, 1885, nota 5, p. 115 y lám. XVI). Un interesante estudio sobre el material cerámico de necrópolis puede verse en Vargas (2002). 

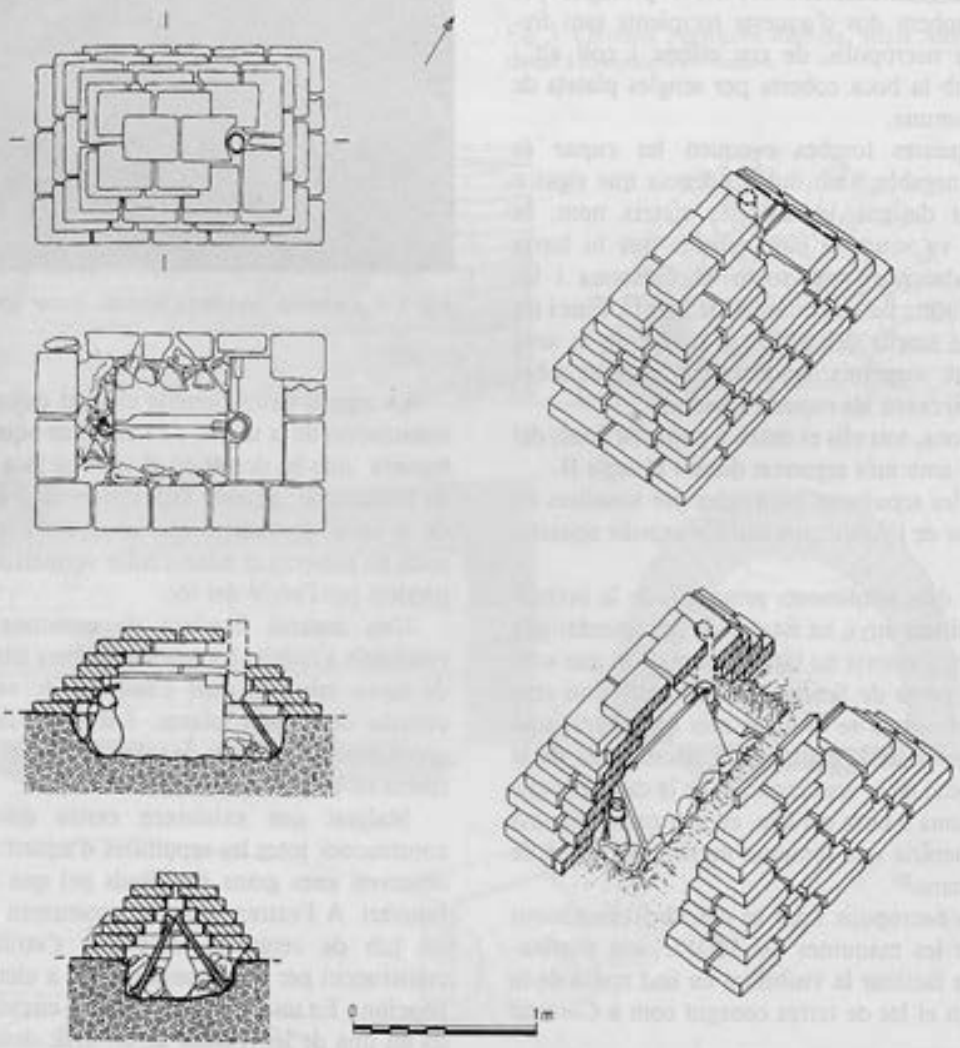

30. Necrópolis oeste de Carmona (Belén, 1983, 58).

Análisis de las tumbas. Las inhumaciones

Se ha considerado que la humatio, cuyas ceremonias fúnebres eran similares a las de la incineratio (incluso participaba de la humatio en su parte final), constituía una actitud individual y conformista ante la muerte y la descomposición del cuerpo de forma natural, frente a la purificación que el fuego proporcionaba (Van Ossel, 1991, 212).

Han transcurrido más de treinta años del tratamiento exhaustivo que A. Van Doorselaer realizó sobre la inhumación en su estudio de las necró- 
polis romanas del norte de la Galia. Se planteaba entonces si la adopción del rito de incineración o del de inhumación respondía a tradiciones locales o simplemente se trataba de una moda. ${ }^{22}$ La tesis propuesta concluía que el aumento progresivo del número de sepulturas de inhumación en el siglo II, aunque se debiera al influjo romanizador, no bastaba para explicar la existencia de esta en la época de la conquista y en el siglo I (Van Doorselaer, 1967). Incidiendo en el tema, poco más tarde, R. Nierhaus (1969) proponía el rito de la inhumación entre toda una serie de tradiciones indígenas que se mantuvieron tras la conquista romana. Durante la época altoimperial, en Roma coexistieron los dos ritos, si bien no en la misma proporción, hecho que ocurría ya desde la época del Bronce Final y que será una constante, aunque de intensidad muy diversa, hasta el siglo III, predominando siempre con diferencia el rito de la incineración. Pero, de la prohibición expresa en la Ley de las Doce Tablas, en el siglo V a. de C., tanto de inhumar como de incinerar en el interior de la ciudad, se deduce la coexistencia de ambos ritos en Roma. En la gens Cornelia se mantuvo la tradición familiar de inhumar. Esta tradición ancestral se mantenía en algunas regiones de Italia central (Bost, Maurin, 1991, 53, n. 2). También entre los pitagóricos se impuso la inhumación (Nock, 1932, 321-359) y de modo definitivo se impuso con los cristianos (Turcan, 1958, 347). ${ }^{23}$ Ambos perduraron, excepcionalmente en el caso de la humatio, en el periodo altoimperial hasta el triunfo exclusivo de la inhumación en el siglo III. Las primeras inhumaciones en Isola Sacra se datan en el reinado de Antonino (Calza, 1940, 59 y 63). Su absoluto predominio se produjo a finales del siglo III d. de C., y en el siglo IV la incineración fue ya excepcional. ${ }^{24} \mathrm{La}$ inhumación se extendió lentamente, pero de manera constante, arraigando definitivamente en todo el Imperio.

22 Ilustrativo al respecto es el estudio de Morris (1992, 34-42) donde se analiza la práctica y evolución contemporánea de la cremación y la inhumación en Europa desde 1900.

23 Para este autor hay dos textos fundamentales al respecto: Servio (Ad Aen., III.68) y Tertuliano (De Anima, 54, I): el primero de los textos es relativo al principio de solidaridad individual y orgánica del alma y del cuerpo, y el segundo se refiere a la supervivencia parcial del individuo, creencia que impone la práctica de la inhumación. Los textos citados atestiguan la importancia del problema a los ojos de los contemporáneos, y no se trata de una cuestión de moda simplemente — cosa que pudo ser el caso de los primeros sarcófagos asiáticos de Roma-, sino que se incorporó a la costumbre por la fuerza de las doctrinas que la justificaban.

24 Macrobio, Saturnalia, VII, 5, se refiere a la incineración como un uso desaparecido a finales del siglo IV. 
En el ceremonial de la consagración imperial, el ritual de la incineración parece pervivir por el poder de ciertas tradiciones familiares y regionales (Turcan, 1958, 332). Si el paso al tipo de la inhumación del enterramiento de los miembros de la familia imperial precedió o se unió al fenómeno de generalización que se observa en Roma es una cuestión debatida (Turcan, 1958; Gros, 1965-1966; Richard, 1966, 1978; Arce, 1988). Fue Antonino el primer emperador en ser inhumado, teniendo en cuenta la discrepancia de los textos al respecto en el caso de Adriano (Turcan, 1958, 328; Richard, 1966, 794-795). No obstante, testimonios de orden numismático sugieren que la incineración es sustituida por la inhumación a la muerte de Faustina la Mayor (140 o 141). Con excepción de los Severos, incinerados por tradición familiar, todos los miembros de las familias imperiales fueron inhumados a partir del enterramiento de Faustina la Mayor, en el 141 (Richard, 1966, 797).

Las estructuras destinadas a los enterramientos eran las mismas e igual de diversas que las utilizadas en la cremación — recuérdense, por ejemplo, los monumentos fúnebres, que generalmente son comunes a ambos ritos-. En ocasiones, las tumbas con inhumación pueden tener dimensiones más grandes, en función de la talla del cadáver y de la abundancia del mobiliario. Su longitud varía entre 1,80 y 2,10 $\mathrm{m}$ y su anchura entre $0,60 \mathrm{~m}$ y $1 \mathrm{~m}$, mientras que la profundidad está condicionada por la naturaleza del suelo: en un suelo ligero se encontrarán más hondas que en uno rocoso. Sin embargo, se ha podido constatar que en un mismo cementerio, algunas tumbas son más profundas que otras ${ }^{25}$. Generalmente, las tumbas de inhumación tienen mayor profundidad que las de incineración, siendo la media más habitual un metro, medida universal en la historia de este rito a lo largo de la geografía y del tiempo. Así, en el caso del cementerio de época islámica de la misma excavación de la calle Predicadores, esa fue también la profundidad estimada por término medio.

Las tumbas solían estar provistas de un medio de protección. Al respecto, los dos tipos que cita Van Doorselaer ${ }^{26}$ estuvieron presentes en la necrópolis occidental de Caesaraugusta: cajas de madera y tejas o piedras -o ambas asociadas.

25 Por ejemplo, en la necrópolis de Blicquy. Van Doorselaer (1967), 164.

26 Van Doorselaer (1967), 149, refiriéndose a la necrópolis del norte de la Galia. 
En el primer caso, a veces las sepulturas han proporcionado huellas de madera procedentes de planchas o tablas aplicadas contra las paredes de la fosa, resultando de ello una especie de encofrado, y en otros casos, aparecen las huellas de las tablas y el emplazamiento de clavos, de manera que debe deducirse en este caso que el cadáver se depositó en un ataúd (Tumbas VII, VIII, IX, XI, XII y XIII). En el segundo tipo, las tejas y piedras se utilizan indiscriminadamente. A menudo la protección de las tumbas era muy rudimentaria y una tumba podía encontrarse rodeada total o parcialmente de piedras (Tumba X).

El uso de la inhumación tuvo un dilatadísimo protagonismo en la historia urbana de esta parte de la ciudad. Así, probablemente ya desde finales del siglo II, hasta el final de la ocupación islámica, es decir, hasta comienzos del siglo XII, se realizaron inhumaciones de forma continuada, siendo también la elegida para la ubicación de un edificio de culto cristiano a finales del siglo IV o comienzos del siglo V (vid. la p. 12). Como es natural, en un periodo de tiempo de mil años el rito sufrió las variaciones que las diferentes culturas introdujeron en sus rituales funerarios, y de ello quedó excelente testimonio en el subsuelo de los solares de la calle Predicadores.

Es probable que los primeros personajes depositados en la tierra y cubiertos por ella pertenecieran a finales de la época antonina, generalizándose este rito a lo largo del siglo III. Sus tumbas se hallaron intactas y ello permitió conocer gran parte de sus características. Invariablemente se practicó una fosa con escalón, revestida de trozos de tegulae, en la que se introdujo el ataúd del que se conservaban restos de madera y clavos, y en su interior algunos objetos pertenecientes a la vestimenta, vajilla utilizada en la ceremonia fúnebre y monedas, por lo general. El sellado se realizó con tegulae y, aunque en la mayoría de los casos estaban aplastadas sobre los restos óseos cuando se hallaron, en el momento de la inhumación es posible que estuvieran colocadas a doble vertiente, si bien no hay que descartar la techumbre plana; curiosamente, el modo habitual de detectar estas tumbas estaba constituido por el hallazgo de un vacío sobre las tegulae, producido por el desplome de los ladrillos de cubierta sobre el lugar del cadáver ya descompuesto. Es importante destacar la uniformidad de todas ellas, salvo en el caso del enterramiento de dos de los niños (Tumbas V y VI).

Estratigráficamente, todas las fosas estaban excavadas en los niveles de abandono y destrucción de la domus de principios del siglo I, rompiendo sus zócalos de sillería de alabastro y sus paredes de adobes derrumbadas. 
Además de este conjunto cuya tipología y cronología es homogénea, de la época tardoantigua han quedado escasos testimonios, aunque estos permiten también conocer otras peculiaridades: son enterramientos con lajas de piedra y no había restos de cajas ni de ofrendas de ningún tipo. La causa de la precariedad de la conservación de estos enterramientos tardíos se debía a la incursión de tumbas islámicas en las cristianas a las que prácticamente destruyeron. Precisamente, la casi total ausencia de enterramientos musulmanes al sur de la vía (es decir, al sur de la calle Predicadores, espacio dedicado en época islámica a arrabal alfarero; Galve, en prensa) permite circunscribir el cementerio islámico a esta parte septentrional. No ocurre lo mismo, como se ha citado, en el caso del mundo funerario paleocristiano y altomedieval, del que se han producido hallazgos muy significativos ya señalados (calles Dosset y San Blas).

A la dominación musulmana pertenecen tres centenares de inhumaciones que tuvieron lugar en este mismo espacio y que se realizaron con arreglo al rito islámico, atestiguado de manera uniforme a lo largo de más de trescientos años (Maqbarah bab-al Tuylatulat). Pudieron ser diferenciados tres niveles de ocupación cuyas principales características son la sobriedad, la cubierta de adobes y, por supuesto, su disposición en la tumba en decúbito lateral derecho y extremidades ligeramente flexionadas, con el eje del cuerpo orientado SW-NE, y el macizo facial mirando al SE. ${ }^{27}$

Finalmente, se produjo el cambio de función del espacio urbano tras la reconquista cristiana y la fundación del barrio de La Población (San Pablo) poco más tarde, convirtiéndose esta zona en artesanal, tras el traslado allí del mercado.

Las inhumaciones que componían el grupo romano son doce: seis hombres jóvenes, una anciana, dos mujeres adultas, un niño de dos a cuatro años, un neonato y un feto.

\section{Tumba I}

Es un enterramiento infantil en posición decúbito supino, con los brazos a lo largo del tórax y las manos cruzadas sobre la zona ventral. Corresponde a un varón de 2 a 4 años de edad y con una talla de $80-90 \mathrm{~cm}$.

27 La síntesis y las últimas investigaciones sobre esta maqbarah pueden verse en Galve (1995), «Necrópolis islámica de la puerta de Toledo (Zaragoza): nuevas excavaciones», Acién y Torres (eds.), Estudios sobre cementerios islámicos andalusies, Málaga, 117-136; Galve, en prensa. 


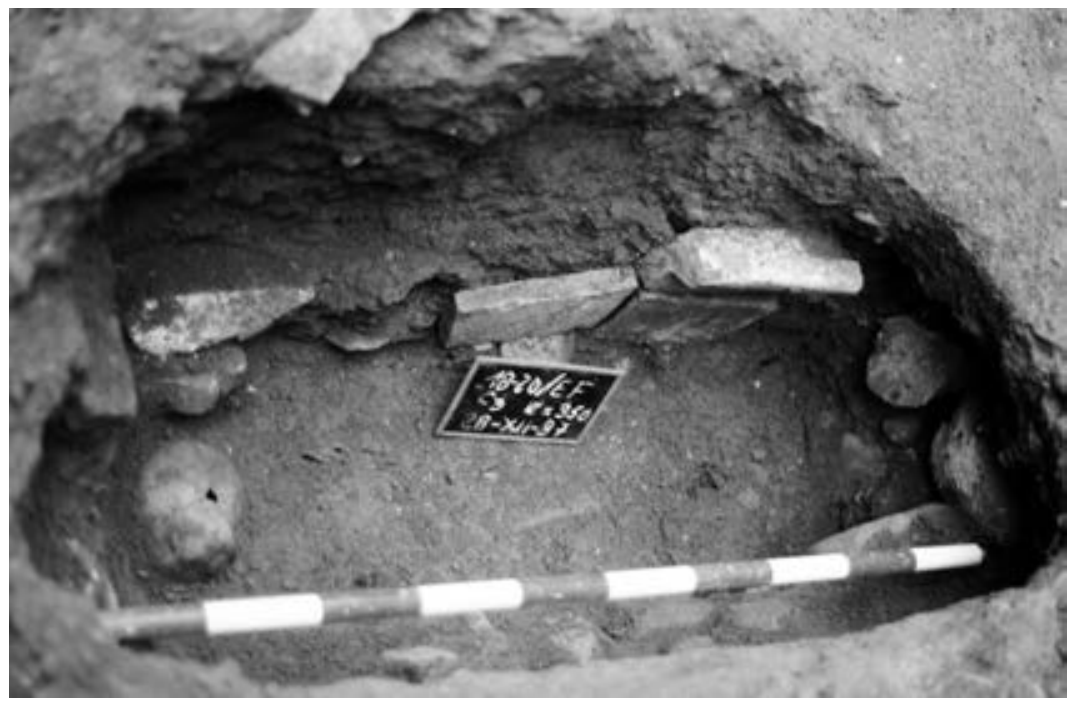

31. La Tumba I en fase inicial de excavación.

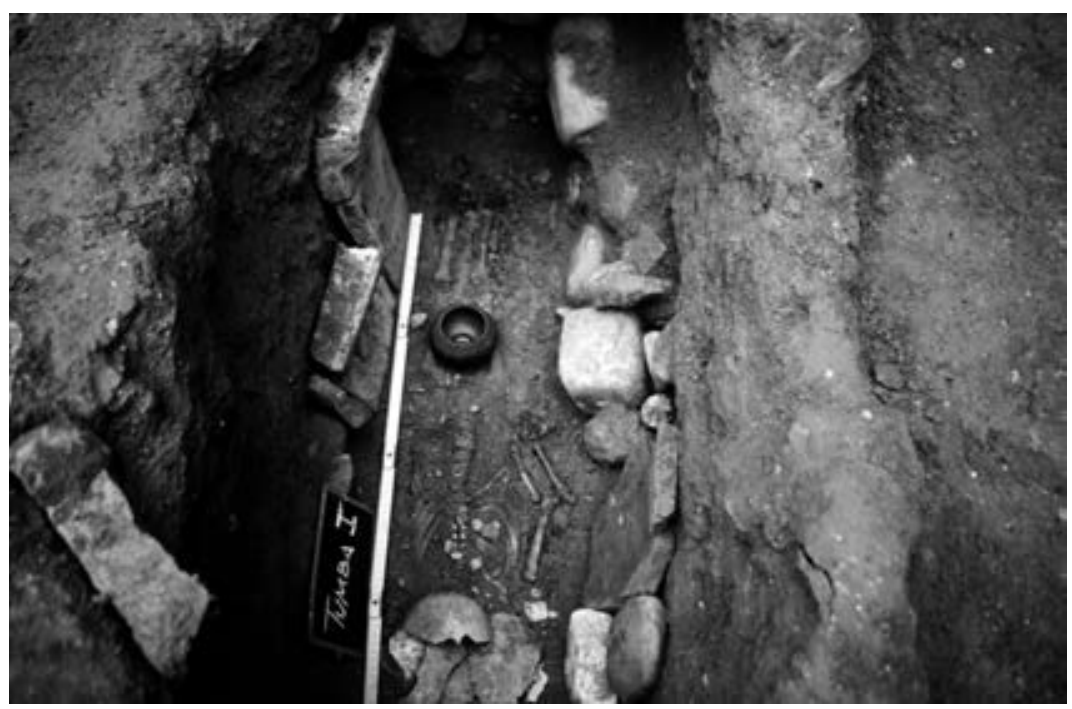

32. La Tumba I en fase final de excavación. 
Se trataba de una fosa con escalón que acogía la inhumación y tenía, como en los demás casos que se citan a continuación, la profundidad adecuada para contener la caja, en torno a $40 \mathrm{~cm}$, mientras que en el escalón había una anchura de entre $10-15 \mathrm{~cm}$. Conservaba restos de la caja de madera en la que fue introducido el cadáver. El hueco de las paredes de la fosa fue revestido de pedazos de tegulae y de piedras que servirían para proporcionar apoyo o servir de relleno para encajar el ataúd en la fosa excavada. Más bien da la impresión de que se hizo la fosa, se introdujo la caja y se rellenó el espacio entre esta y la tierra con tegulae y piedras. La cubierta era también de tegulae, encontrándose en el momento de la excavación en disposición plana horizontal, con el aspecto de aplastamiento - sin embargo, y aun cuando en el dibujo de la sección de esta tumba se ha indicado una cubierta plana, en realidad, estas tegulae también podrían haber estado dispuestas a doble vertiente, ya que el vacío todavía presente sobre ellas en el momento de su excavación podría indicar esta disposición.

\section{Depósito funerario}

Aunque solo se encontraron dos piezas, puede ser significativo el hecho de que una de ellas fuera una prenda de adorno personal, un pequeño anillo, y otra de uso ceremonial, representado por un vasito cerámico.

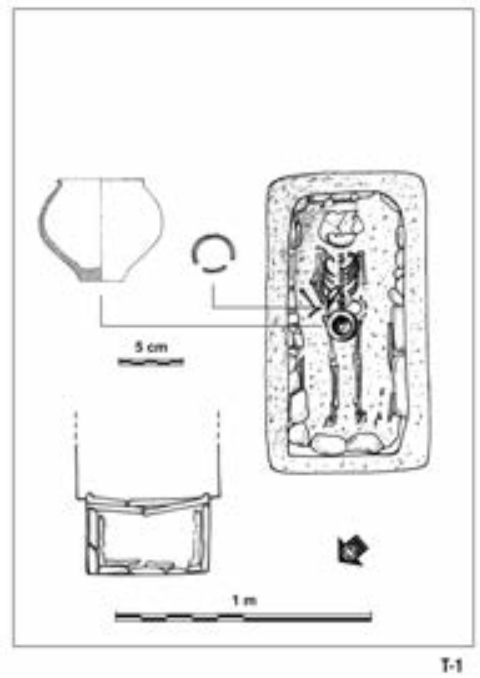

33. La Tumba I. 

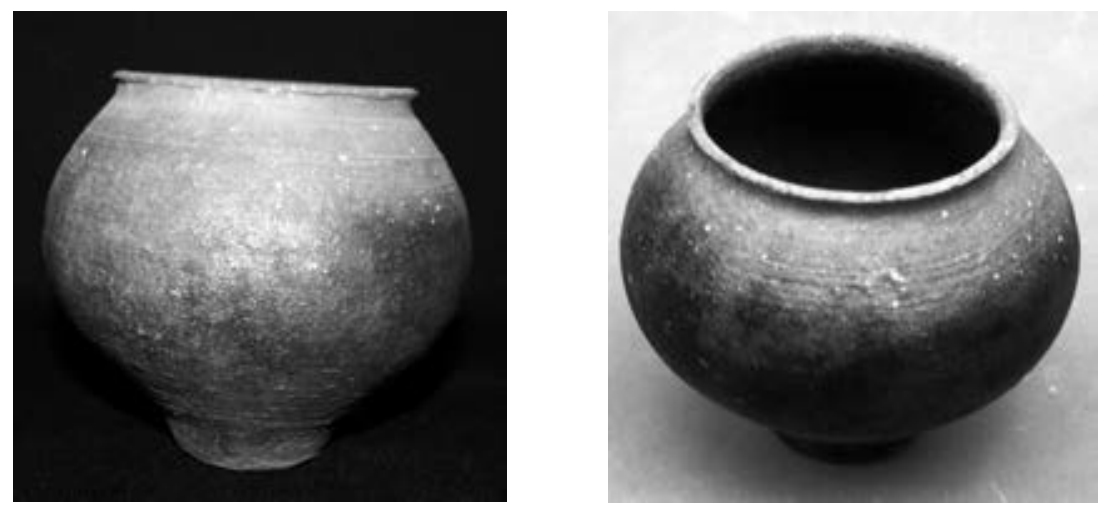

34-35. Vasito de ofrenda en el interior de la tumba.

La ubicación de ambos era, en el caso del aro de bronce, la zona de las manos, sin que podamos precisar más al respecto, y la del vaso sobre los fémures y de pie. Este hecho es bastante habitual en inhumaciones del siglo III o principios del siglo IV. Por citar algún ejemplo, una inhumación (tumba 145) de la necrópolis de Sitifis (Sétif, Argelia) presentaba también una pieza de cerámica entre las piernas (Fèvrier, Gaspary, 1966-1967, fig. 11). Esta necrópolis cuenta con incineraciones provistas también de tubo de libaciones e inhumaciones hasta el siglo III. Por otra parte, y en lo que respecta al vasito, esta forma cerámica es frecuente encontrarla entre las ofrendas funerarias: su presencia es abundante en la necrópolis del Puerto de Avenches (Castellá, 1987, 104-106) y en enterramientos hispanos como la necrópolis del «Cerrillo de los Gordos» en Cástulo (Canto, Urruela, 1979, 336, fig. 156; en este caso se trata de una incineración). También se recuperaron dos posibles botones o remaches de bronce en el mismo contexto.

Cronologia: por sus características estratigráficas y tipológicas similares al resto de tumbas del grupo debe situarse en el siglo III.

1. Vasito de cerámica de pasta arenosa. Forma ovoide con borde ligeramente vuelto. Pasta clara con finas inclusiones arenosas. Pieza restaurada. Dimensiones: $8 \times 9 \mathrm{~cm}$. Datación: siglo II d. de C. Sigla: 88.66/ 41.504 (Galve, 1993, n. ${ }^{\circ} 18$ ).

2. Botón de bronce (?). Cabeza redondeada. Sigla: 87.66/22.725. 
3. Botón de bronce (?). Cabeza plana. Sigla: 87.66/ 22.726.

4. Fragmento de pieza de bronce (¿punzón?). Sigla: 87.66/22.727.

5. Anillo de hierro en aro. Desaparecido por su mal estado de conservación (se ha representado en la lámina porque formaba parte del adorno personal; el diámetro que puede obtenerse del dibujo es el real que presentaba en el momento de su hallazgo).

\section{Tumba II}

Esta tumba solamente pudo evidenciarse por el vacío encontrado cuando se excavó, y a pesar de que no se conservaba ningún resto óseo, debió presentar las mismas características que las demás. La cota de la cubierta, calculada por dicho vacío, era de 200.09 m. s. n. m. La topografía indicaba la misma característica cronológica que las de su entorno.

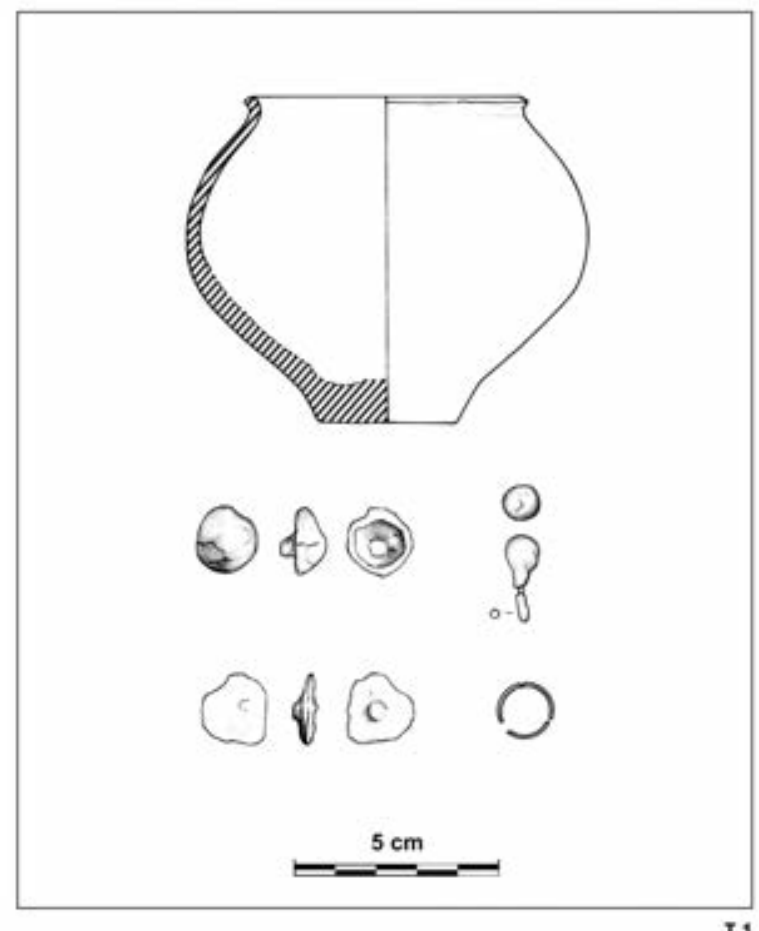

36. Ajuar de la Tumba I. 


\section{Tumba III}

Se trata del enterramiento de un varón de 24 a 28 años de edad y con una estatura de 160 a $170 \mathrm{~cm}$. Cota absoluta bajo el cráneo: $199.24 \mathrm{~m}$. s. n. $\mathrm{m} .{ }^{28}$ Se trata también de una inhumación en fosa escalonada en cuyo interior se conservaban restos del ataúd. Como en el primer caso, el individuo estaba cubierto por tegulae horizontales y desconocemos, como en el caso de la Tumba I, si se trataba de un cubrimiento a doble vertiente o plano.

Del estudio antropológico se han derivado hallazgos de gran interés paleopatológico. Entre otros, en primer lugar, sobresalen los marcadores de estrés óseo a nivel de la cara anterior de la rótula y en la cara posterior del calcáneo por la impronta del tendón rotuliano y del de Aquiles, y, en segundo lugar, se ha constatado un importante grado de desgaste dental en todas las piezas conservadas. De esto se desprende una gran actividad en marchas prolongadas y situaciones frecuentes de estrés (véanse las pp. 197-198).

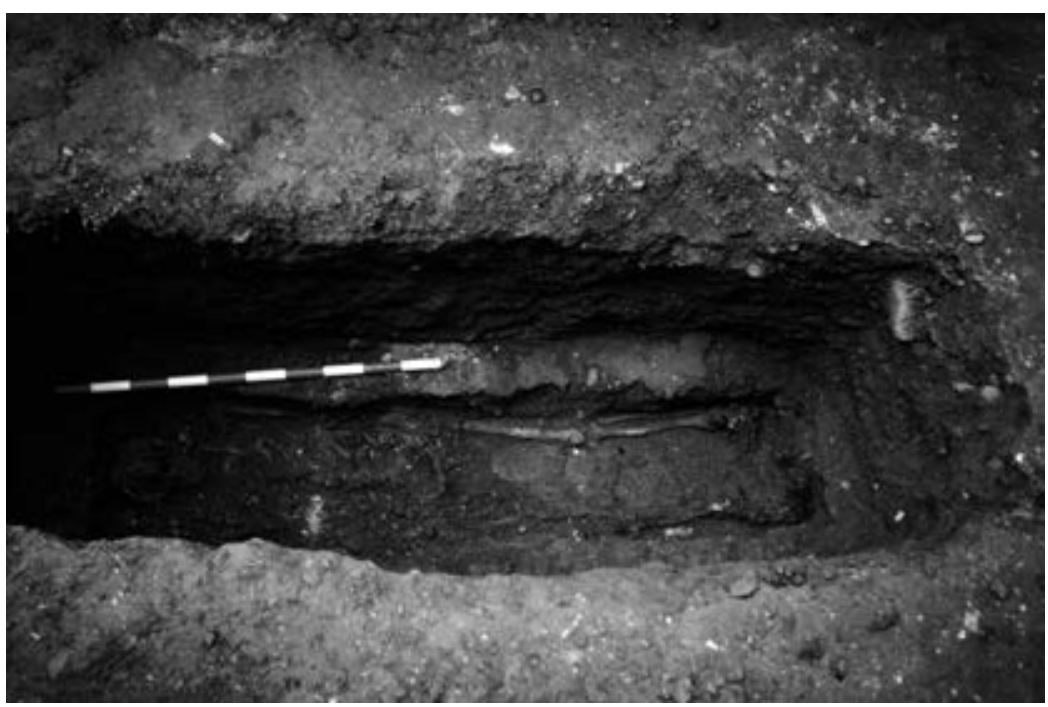

37. El individuo presentaba el cráneo en el sur.

28 La diferencia de cotas entre los enterramientos se debe a la imposibilidad de tomarlas en un mismo sitio, generalmente el cráneo, como hubiera sido de desear, a causa del estado de conservación de los restos óseos, diferente en cada una de las tumbas. 


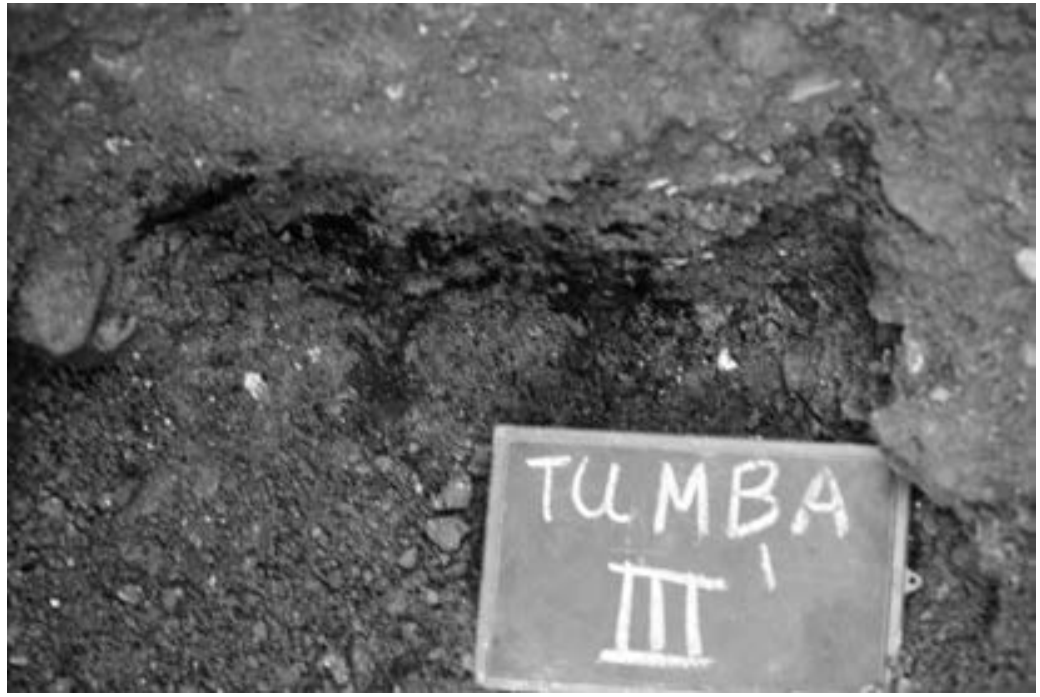

38. Obsérvense los restos de clavos de hierro y de madera que todavía se conservaban.

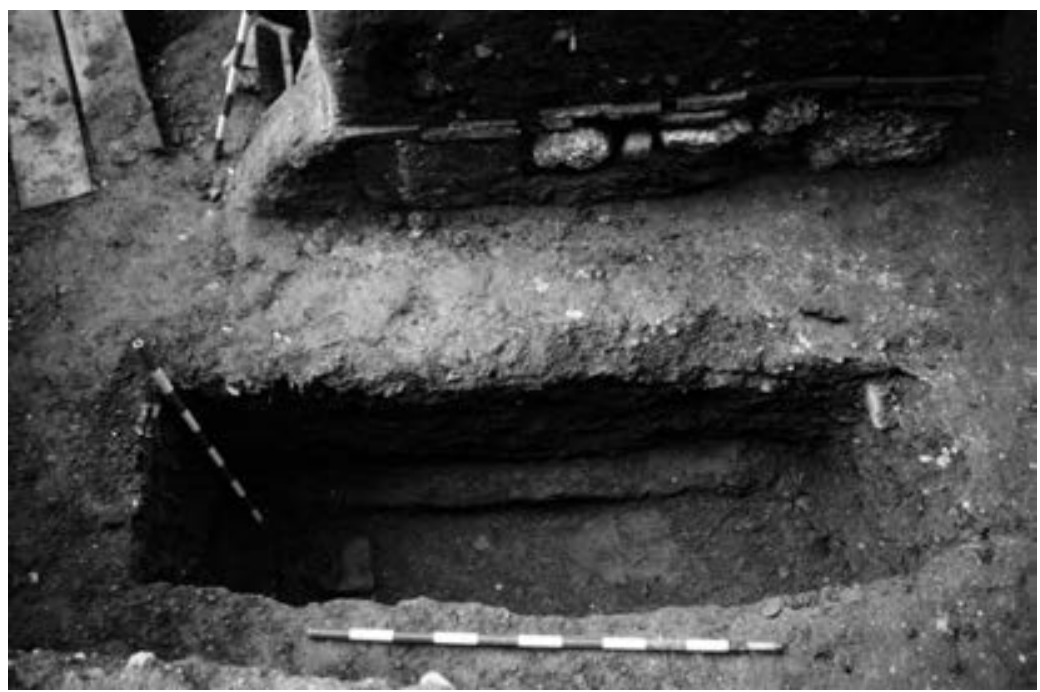

39. La Tumba III en la parte inferior y el alzado del monumento (Inc. I) en la de arriba. 


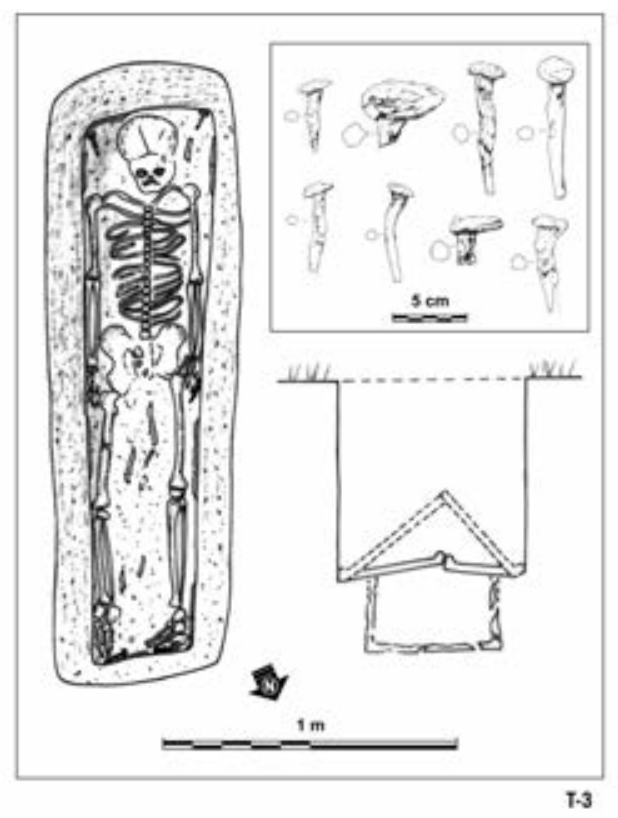

40. La Tumba III.

\section{Depósito funerario}

Carecía tanto de adornos personales como de objetos rituales. Tan solo se localizaron algunos clavos de hierro procedentes, sin duda, de la caja de madera.

La sigla (87.66/ 41.491) es la misma para todas las piezas.

1. Clavo de hierro. Longitud máxima conservada: $5 \mathrm{~cm}$. Cabeza redondeada. Diámetro máximo del tallo: $9 \mathrm{~mm}$. Sigla: 87.66/ 41.491.

2. Clavo de hierro. Longitud máxima conservada: $6 \mathrm{~cm}$. Diámetro máximo del vástago: $7 \mathrm{~mm}$.

3. Clavo de hierro. Longitud máxima conservada: $6,5 \mathrm{~cm}$. Diámetro del vástago: $1 \mathrm{~cm}$.

4. Clavo de hierro. Longitud máxima conservada: $7 \mathrm{~cm}$. Diámetro del vástago: $7 \mathrm{~mm}$. 
5. Clavo de hierro. Longitud máxima conservada: $9 \mathrm{~cm}$. Diámetro del vástago: $1 \mathrm{~cm}$.

6. Clavo de hierro. Se conserva la cabeza y una pequeña parte del vástago. Dimensiones de la cabeza: $5,5 \mathrm{~cm}$. Diámetro del vástago: 1,5 $\mathrm{cm}$.

7. Clavo de hierro. Longitud máxima conservada: $9,52 \mathrm{~cm}$. Diámetro del vástago: $1 \mathrm{~cm}$.

8. Clavo de hierro. Longitud máxima conservada: $3,5 \mathrm{~cm}$. Diámetro del vástago: $1,2 \mathrm{~cm}$.

\section{Datación}

Poseemos en este caso la datación radiocarbónica que proporcionó la fecha $289 \pm 30 .^{29}$ Si la datación es correcta resulta una diferencia de unos cincuenta años con respecto al monumento, que se data a principios del siglo.

\section{Tumba IV}

Constituye la inhumación de un individuo adulto, en fosa escalonada, también con clavos de hierro y restos de madera del ataúd, y con la cubierta similar a las anteriormente descritas, es decir, conservando un vacío sobre ellas producido por la presión de las tierras sobre las tejas. El cadáver fue depositado en decúbito supino con los brazos cruzados y paralelos. La edad del individuo se ha podido calcular con dos criterios diferentes, resultando mediante uno de ellos cercano a los veinte años, mientras que con el otro podría haber muerto entre los 24 y 28 años. La talla aproximada era de $163-173 \mathrm{~cm}$.

Se han encontrado también marcadores de estrés óseo en el húmero y el fémur y gran desgaste dental. Estas características podrían aplicarse a la gran actividad física y a la dieta alimenticia (véanse las pp. 203-204).

\section{Depósito funerario}

Como único elemento de ofrenda apareció una moneda de Filipo el Árabe (Monetario Municipal n. ${ }^{\circ} 44$ ) y formando contexto dudoso con la tumba se recogieron un denario de Trajano (Monetario Municipal n. $\left.{ }^{\circ} 45\right)$ y

29 Las muestras fueron analizadas en el Centrum voor Isotopen Onderzoek, Rijks Universiteit de Groningen. [GrN-15649] 
un posible dupondio $(31 \mathrm{~mm})$, ilegible, recogido bajo la tibia izquierda ( . $^{\circ}$ 43 del Monetario Municipal). Estas dos últimas monedas deberían considerarse pertenecientes a un momento ante quem a la inhumación, por lo que no se relacionan en el depósito funerario. Se suman, además, tres clavos de hierro de la caja de madera (cota: 199.24 m. s. n. m.).

1. Clavo de hierro. Longitud máxima: $7,6 \mathrm{~cm}$. Diámetro del vástago: $8 \mathrm{~mm}$. Sigla: 87.66/ 41.492. La sigla es la misma para los dos clavos siguientes.

2. Clavo de hierro. Longitud máxima: $4,6 \mathrm{~cm}$. Diámetro: $1 \mathrm{~cm}$.

3. Clavo de hierro. Longitud máxima conservada: $3 \mathrm{~cm}$. Diámetro del vástago: $9 \mathrm{~mm}$.

4. Moneda de bronce. Filipo el Árabe (244-249). Se trata de un sestercio. Ceca: Roma. (R.I.C. IV-III 90/174a). Monetario n. ${ }^{\circ} 44$. Sigla: 97.66/40.904.

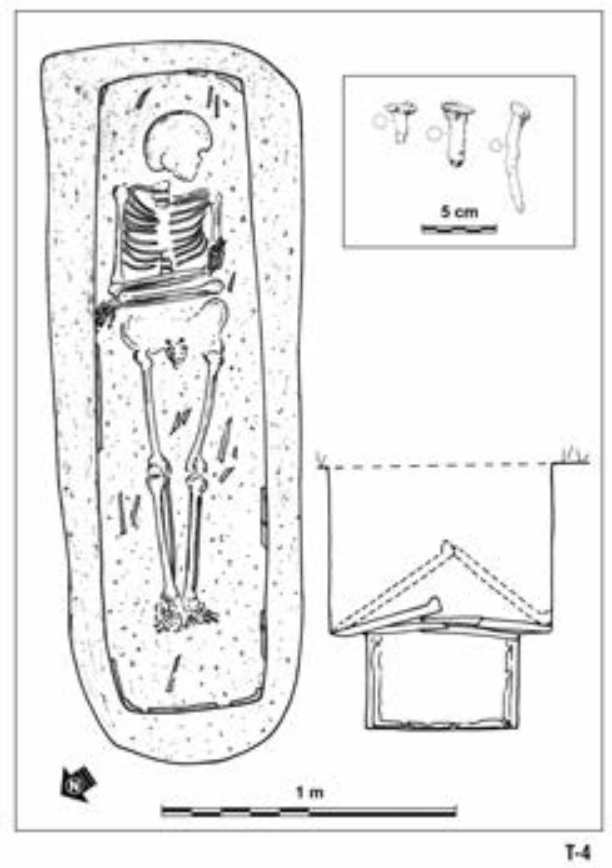

41. La Tumba IV. 


\section{Cronología}

Los restos óseos se dataron por radiocarbono en $205 \pm 35[\mathrm{GrN}-$ 15650]. La moneda de Filipo el Árabe proporciona a este enterramiento una fecha post quem mediado el siglo III (244-249).

\section{Tumba $V$}

Se trata en este caso de la inhumación del feto de un varón de 28 a 32 semanas de gestación con una talla de 37 a 44 cm (véanse las pp. 207-208) que, depositado sobre el lado izquierdo, tenía orientado el cráneo hacia el NE y las piernas ligeramente flexionadas. La estructura asociada al cadáver estaba muy deteriorada, sobre todo la parte relativa a la cubierta, que no se conservaba, aunque sí se pudo comprobar que debió ser introducido en una pequeña caja, ya que presentaba restos de madera. En las proximidades de la fosa se conservaba un amontonamiento de piedras que es probable que formara parte de alguna indicación de la misma en el exterior.

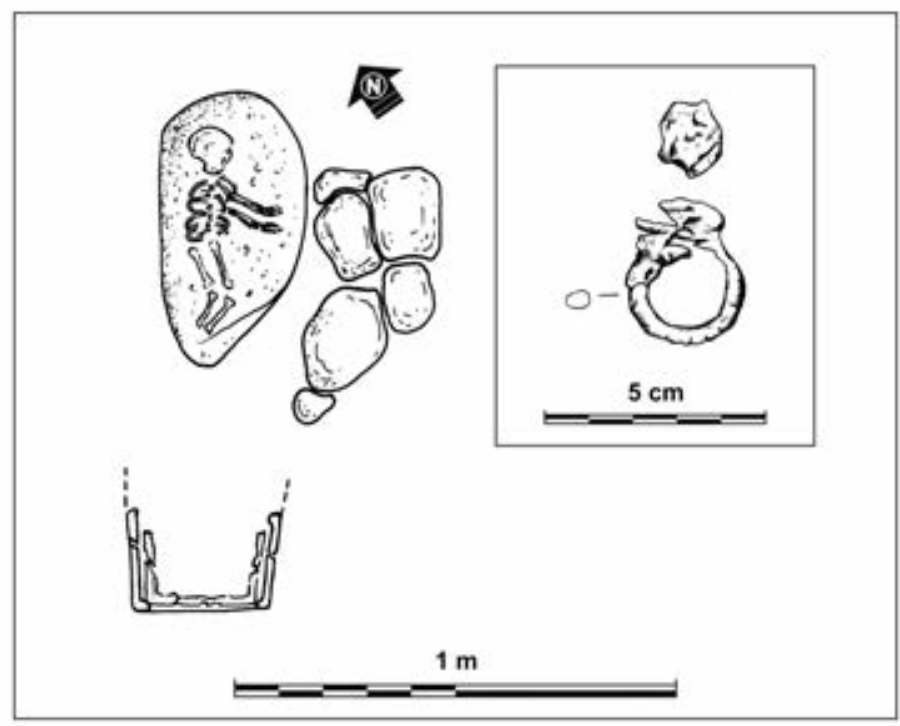

42. Tumba V. 


\section{Depósito funerario}

1. Objeto de bronce de forma circular. Diámetro: $2,6 \mathrm{~cm}$. Sigla: $87.66 /$ 41.493. En un principio se catalogó como bulla, pero tras su limpieza no parece haber criterio suficiente para ello.

\section{Tumba VI}

Constituye la inhumación de un «feto a término» o recién nacido, posiblemente femenino, con talla estimada entre 47 y $52 \mathrm{~cm}$ en sepultura en fosa (véase la p. 210). El pequeño cadáver fue depositado a lo largo de una teja curva, cubierto con otra de tal manera que quedara un espacio entre ambos, y al lado se apoyó una tercera para rellenar el hueco de la fosa totalmente. Sobre este envase funerario se colocaron varias tegulae. Carecía de ofrendas o ajuar. Es interesante señalar la superficialidad de esta inhumación en comparación con el resto. Como único material asociado se recuperó una plaquita de bronce muy deteriorada (Sigla: 87.66/ 41.494. Cota del fondo de la fosa: 200.64 m. s. n. m.).

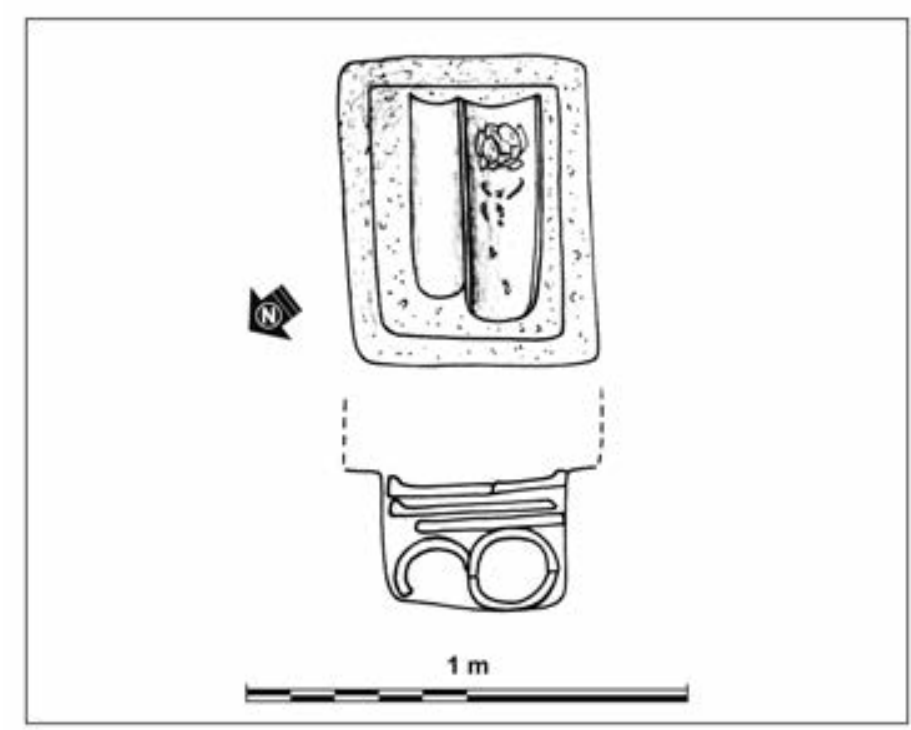

43. Tumba VI. 


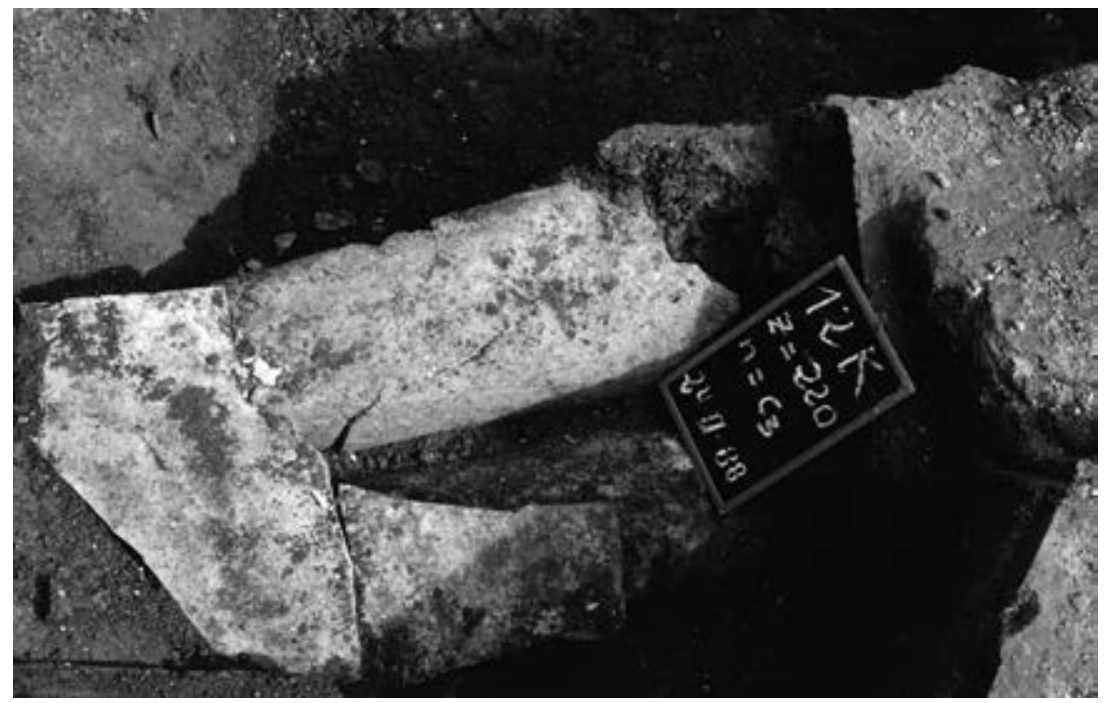

44. Parte superior de la Tumba VI cuya cubierta estaba constituida por tejas planas.

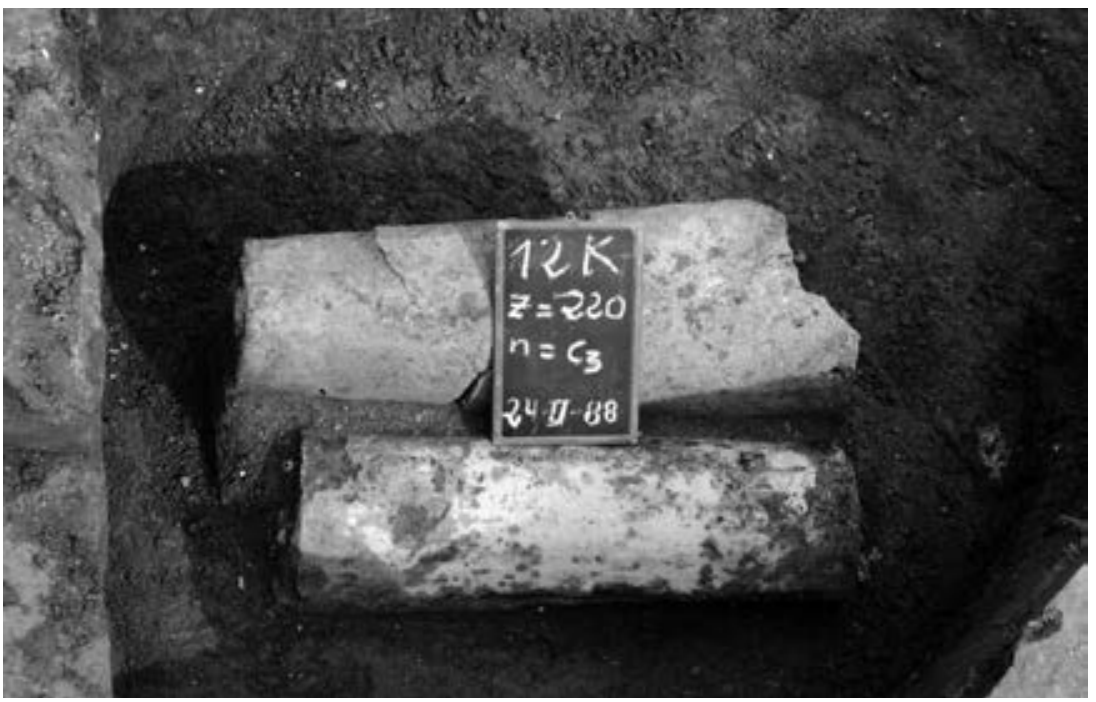

45. Tumba VI. El pequeño cadáver se colocó en una teja curva y se cubrió con otra. A uno de sus lados se apoyó otra. 


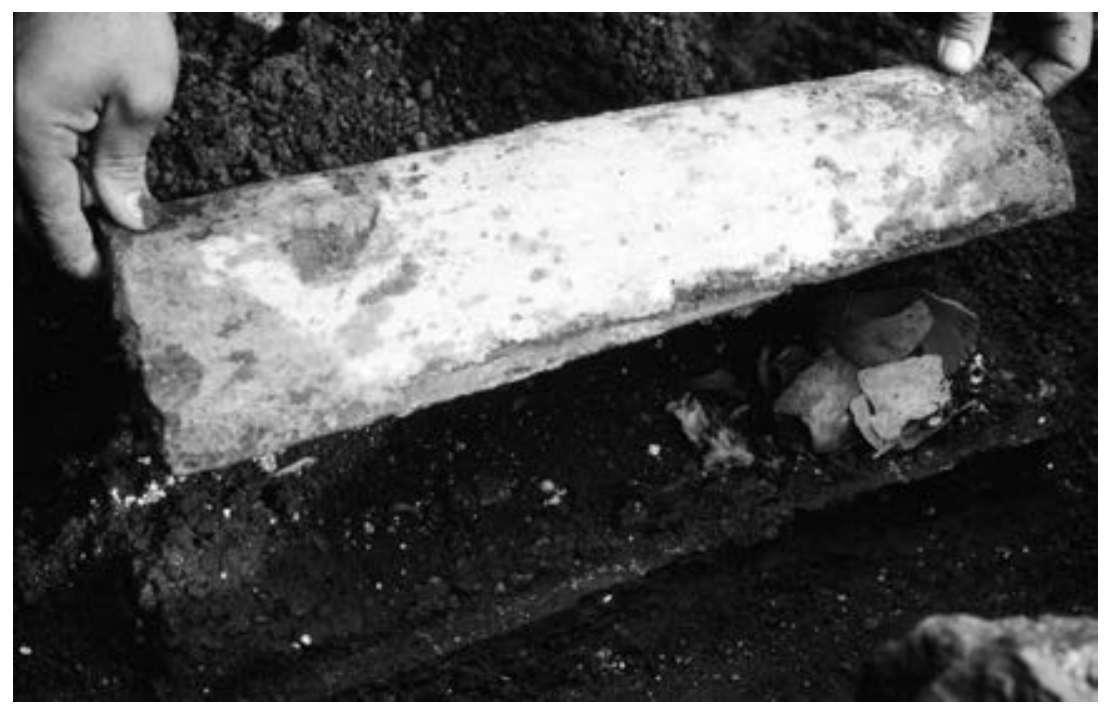

46. Tumba VI. Momento en el que se vio el interior del estuche funerario formado por dos ímbrices.

\section{Tumba VII}

Se trata de una inhumación de un hombre joven de 20 a 23 años y con una talla aproximada de 160 a $165 \mathrm{~cm}$. La fosa estaba escalonada, con restos de caja de madera y clavos de hierro. Tenía los pies cruzados a la altura de los tobillos. La disposición de este enterramiento con respecto al siguiente (Tumba VIII) es gemela, ya que la profundidad de las fosas, su proximidad (separadas solamente por un pequeño tabique) e incluso la similitud que presentaba el atuendo personal (caligae) de los individuos allí enterrados era muy similar. Las mismas características ofreció la Tumba IX.

Otros datos de gran interés están constituidos por los marcadores de estrés óseos, en este caso, en las extremidades superiores, y un importante desgaste dental (véanse las pp. 215-216). Sorprende también el hallazgo en este contexto de huesos de caballo (véanse las pp. 81-82).

\section{Depósito funerario}

Carecía de ofrendas de índole funeraria y, sin embargo, conservaba objetos de adorno o más bien relativos a la indumentaria personal, uno de 
ellos de excepcional importancia: una fíbula de plata colocada en la clavícula derecha y una hebilla de bronce a la altura de los tobillos que, por la situación en la que se encontró y la posición peculiar de los pies - cruzados uno sobre otro-, podría indicar que fuera introducido con los pies atados, aunque lo más probable es que la hebilla formase parte del calzado. Estaba calzado con caligae, como atestiguan los clavos de hierro que se conservaban; al respecto pueden verse ejemplos de este mismo hecho en el cementerio romano de West Tenter Street (Whytehead, 1986, 95) y Eastern Cemetery (Barber, Bowsher, 2000, 157).

Además de los clavos, durante la limpieza del enterramiento se apreciaron restos de fibra de cuero que, por su precario estado de conservación, no pudieron recuperarse.

Por el ajuar que le acompañaba, en particular por la fíbula de plata, es posible que se tratara de un individuo procedente del este de Europa y de índole militar: estaría vestido con grueso manto de lana y con calzado militar.

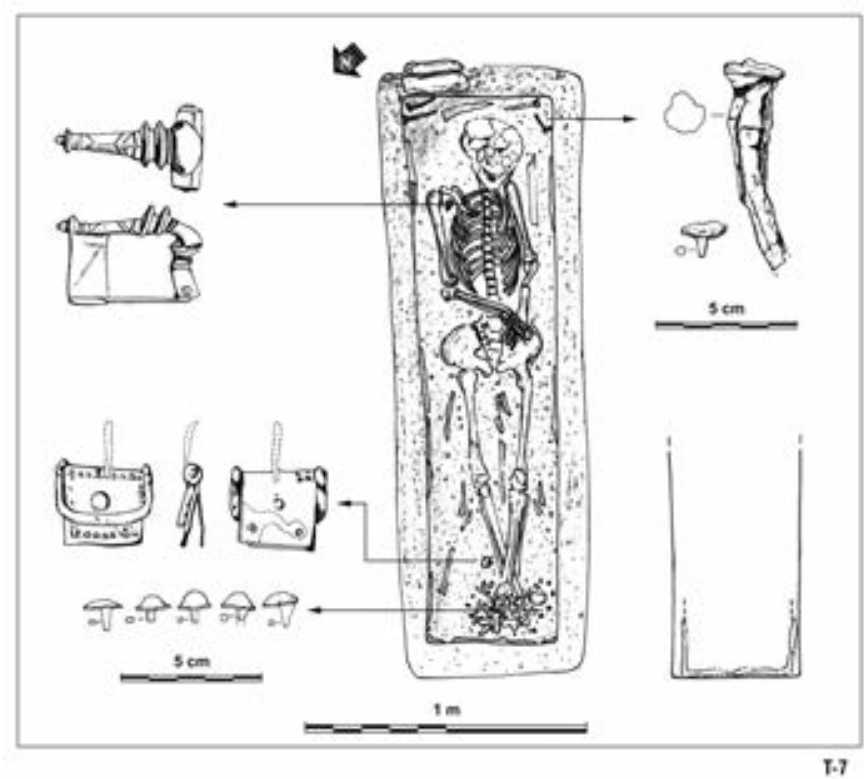

47. Tumba VII. 


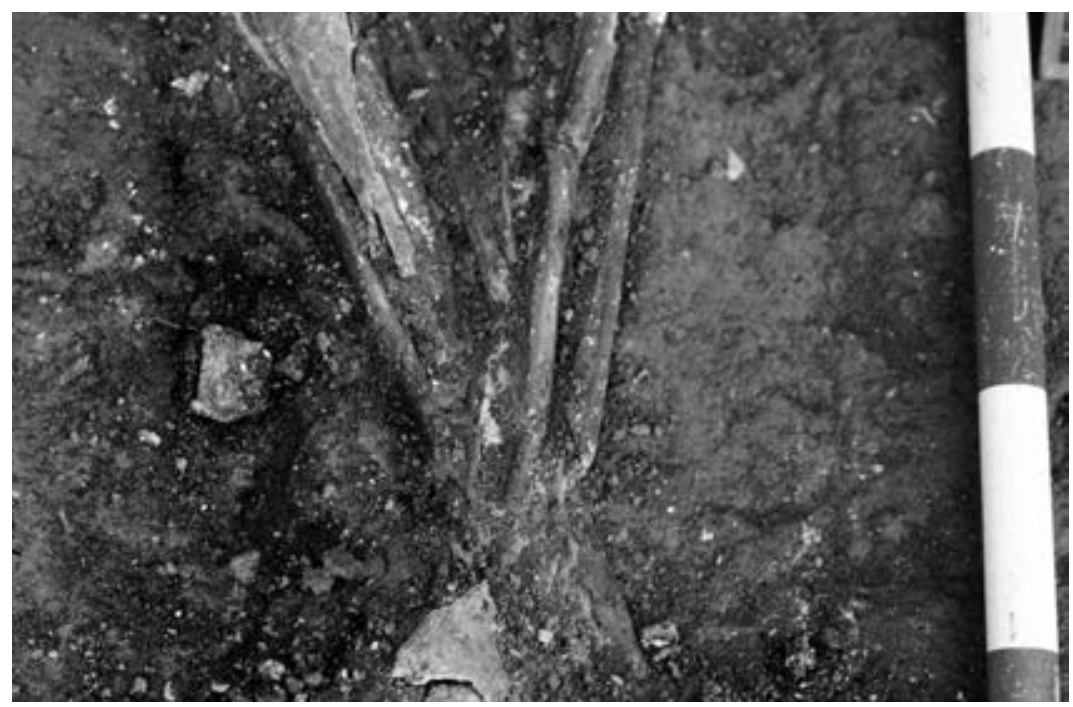

48. Tumba VII. Hebilla de bronce a la altura de los tobillos.

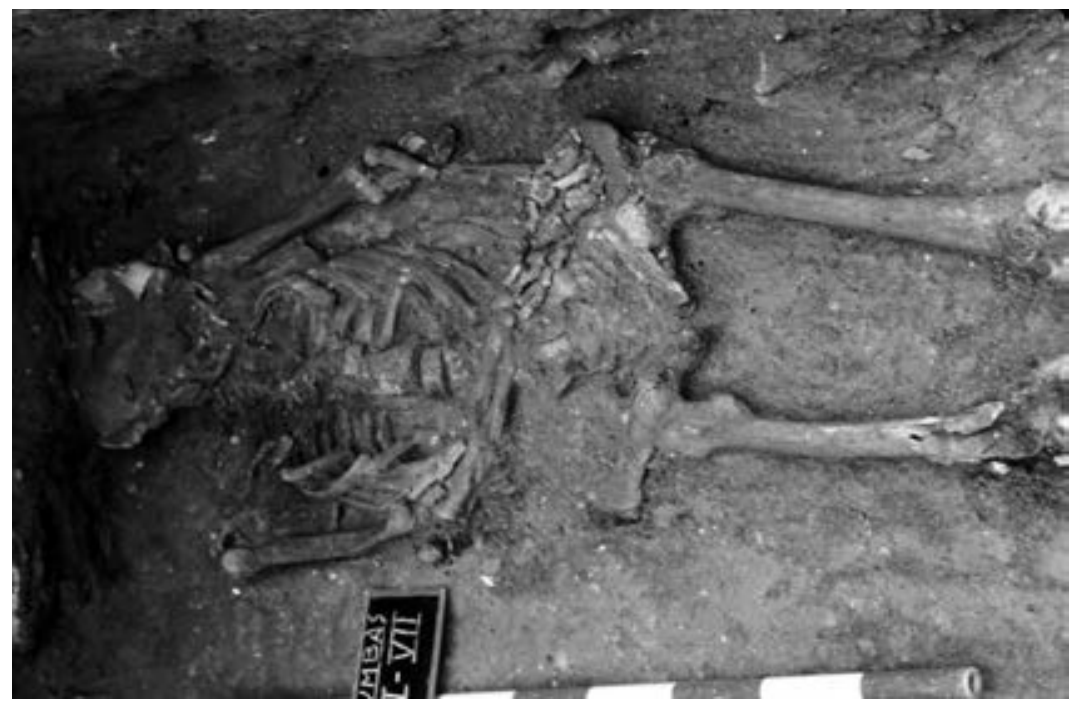

49. Tumba VII. El joven fue inhumado en una caja de madera de la que se aprecian restos, e iba vestido con un grueso ropaje sujeto con una fíbula de plata y calzado. 


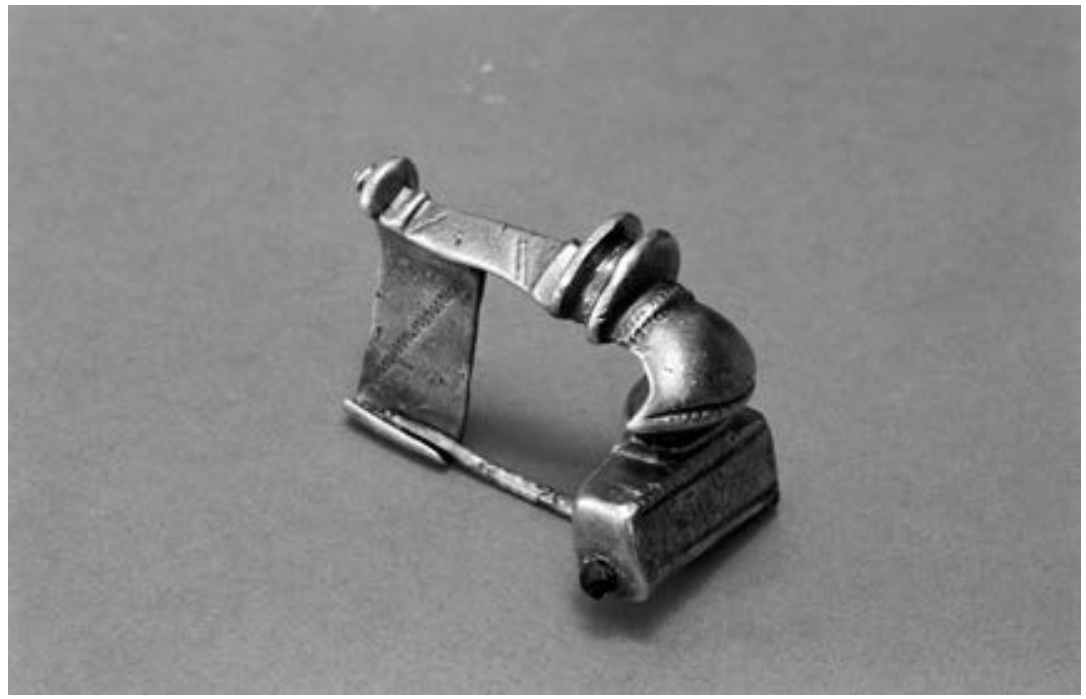

50. Fíbula nórico-panónica de plata de gran pureza con la que el joven de la Tumba VII fue enterrado.

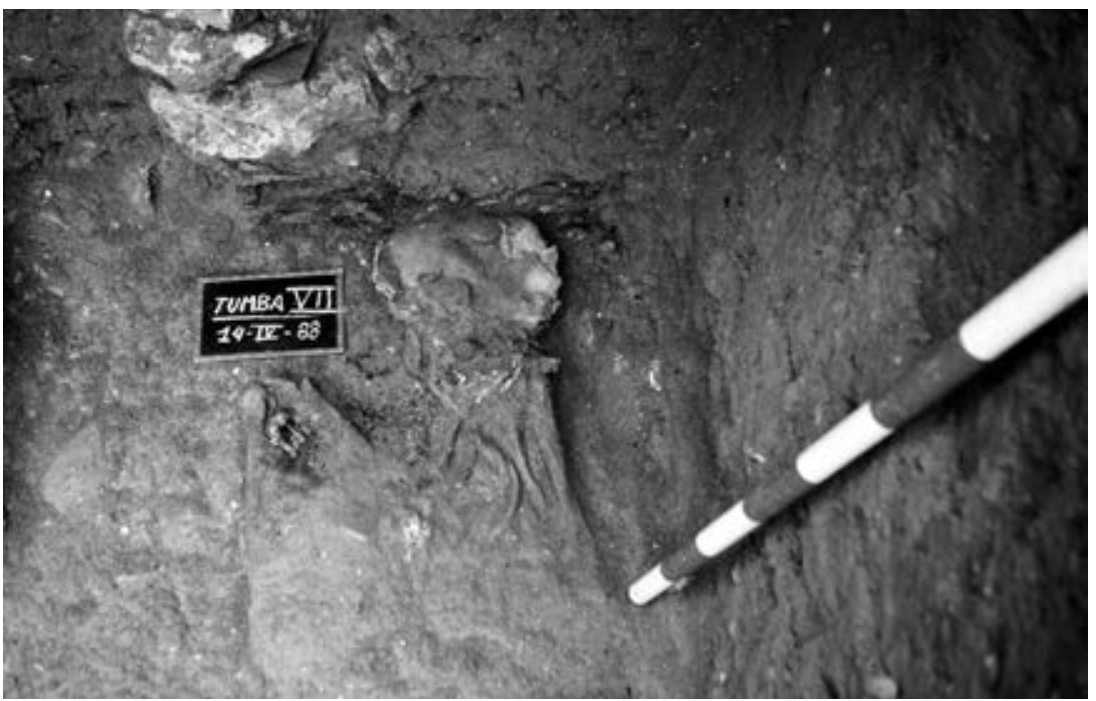

51. La Tumba VII con la fíbula in situ. 
1. Clavo de bronce de caliga. Cabeza aplastada por el uso. Vástago de sección cuadrada. Sigla: 42.495 y una cota de 199,56 m. s. n. m. (la misma para todos los que siguen a continuación).

2. Clavo de bronce de caliga. Cabeza redondeada y vástago de sección cuadrada.

3. Clavo de bronce de caliga. Cabeza redondeada y vástago de sección cuadrada.

4. Clavo de bronce de caliga. Cabeza facetada que debió acabar en punta (también en los casos anteriores, pero es probable que con el uso, aparezcan aplastadas.

5. Clavo de bronce de caliga. Cabeza redondeada y vástago de sección cuadrada.

6. Clavo de bronce de caliga. Muy deteriorado.

7. Fíbula de plata. Dimensiones: 5,1 cm de largo. Peso: 54,3 g. Sigla: 87.66/41.496. Profundidad:199,54 m. s. n. m. Fíbula de tipo «Kräftig Profiliert» de plata y con eje de hierro. El resorte tiene diez espiras y cuerda interior. El cobertor lo constituye una caja poligonal con adornos incisos. El puente, tras un pronunciado arqueamiento, con puntos incisos, se estira hacia el pie. En él se observan las características molduras que se repiten en el botón terminal. El portaagujas es rectangular, largo y estrecho. Debió sujetar sobre el hombro derecho un grueso manto. Cronología: finales del siglo II y siglo III.

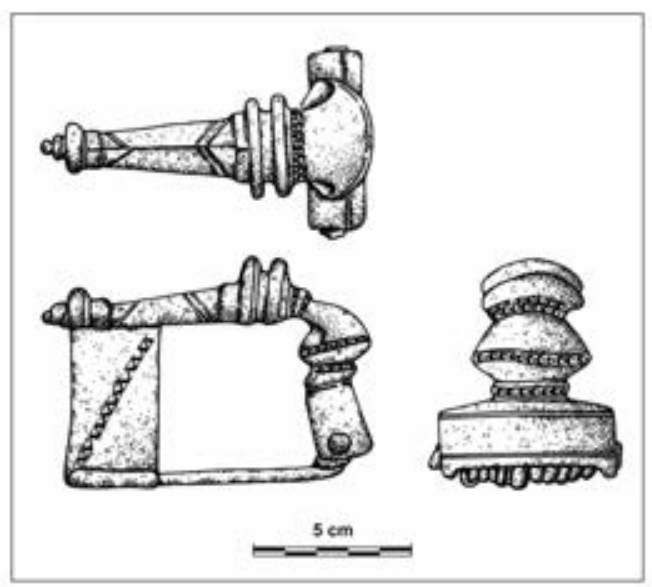

52. La fíbula de plata. 
Se trata de un tipo escasísimo en la Península Ibérica, donde solamente se conocen dos ejemplares, ninguno de ellos de plata: uno en Ampurias (Gerona) y otro hallado en la antigua colonia Celsa (Velilla de Ebro, Zaragoza). Actualmente puede verse la pieza en el Museo de Zaragoza (Sala de Caesaraugusta).

El ejemplar de Zaragoza sería el más moderno, ya que el tipo evoluciona mediante la protección del soporte con una caja rectangular, provocando el cambio al interior del tensor o cuerda. Se trata de un unicum en Occidente de un tipo de Noricum-Pannonia, cuando apenas se encuentra ya en su lugar de origen, salvo en Lauriacum, y extraordinariamente es de plata. Además, está decorado, en contraposición a los ejemplares de este tipo (Erice, 1991, ficha catalográfica 43; 1995, 87-91, Tipo 18.3, n. $\left.{ }^{\circ} 101\right)$.

8. Clavo de hierro. Sigla: $87.66 / 42.498$. Longitud máxima: $7,5 \mathrm{~cm}$. Diámetro del vástago: $1,5 \mathrm{~cm}$.

9. Hebilla de bronce. Sigla: 87.66/ 41.494 .

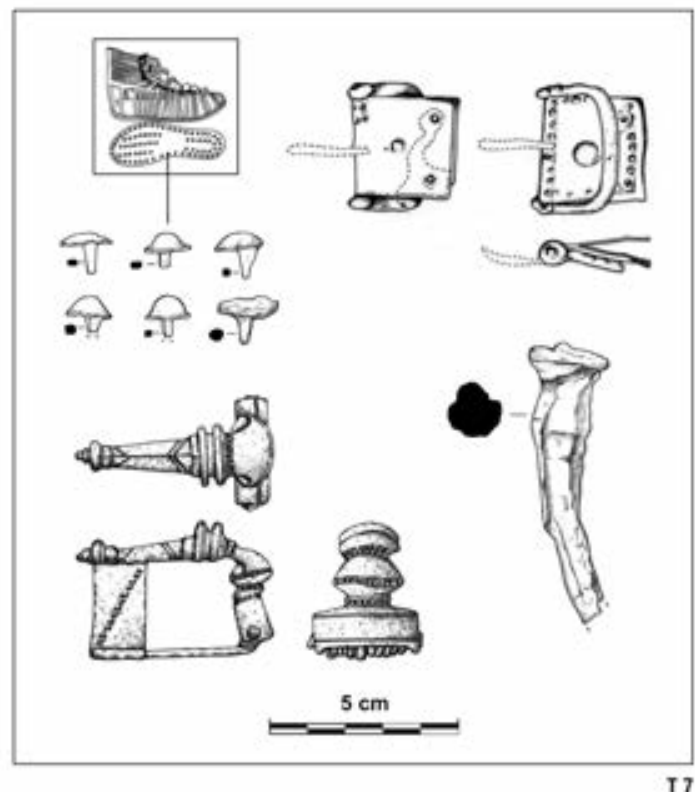

53. Ajuar de la Tumba VII. 


\section{Tumba VIII}

Como se ha citado, la sepultura estaba yuxtapuesta a la anterior. Es muy probable que fueran inhumados al mismo tiempo, ya que se encontraban a la misma profundidad, separados tan solo por un ligero espacio y eran dos fosas de las mismas dimensiones y características.

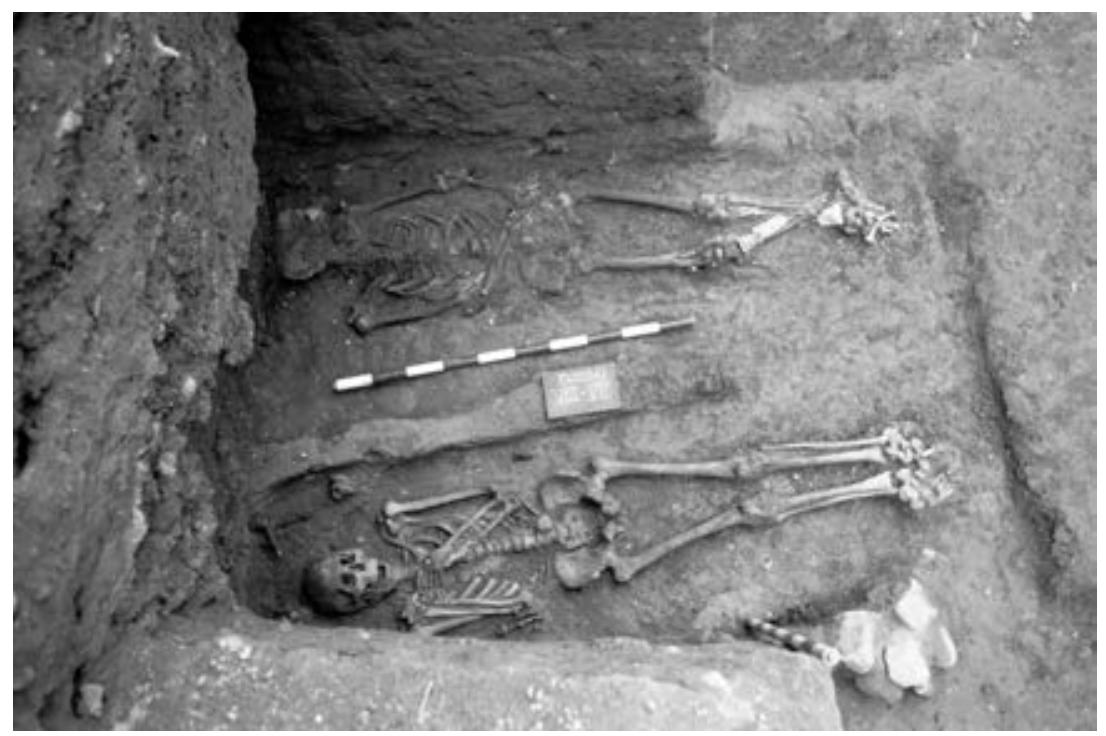

54. Tumbas VII y VIII.

Se trataba de la inhumación de un varón de 24 a 28 años de edad y de talla estimada en 155 a $165 \mathrm{~cm}$, en posición de decúbito supino. La fosa era escalonada y conservaba en su interior restos del ataúd y clavos del mismo.

Respecto a la indumentaria observada durante el proceso de limpieza de los restos óseos, se pudieron recoger restos del calzado compuestos de clavos y restos de fibra de cuero. Se recogió una moneda de Claudio II (†270) entre las tierras que cubrían el enterramiento, a una cota correspondiente a la parte superior de la fosa. El hecho de que se hallara a 1,2 m (200.84 m. s. n. m.) de profundidad por encima de las Tumbas VII y VIII (199.66), puede derivar en un dato ante quem para ambas tumbas con respecto a la moneda. 


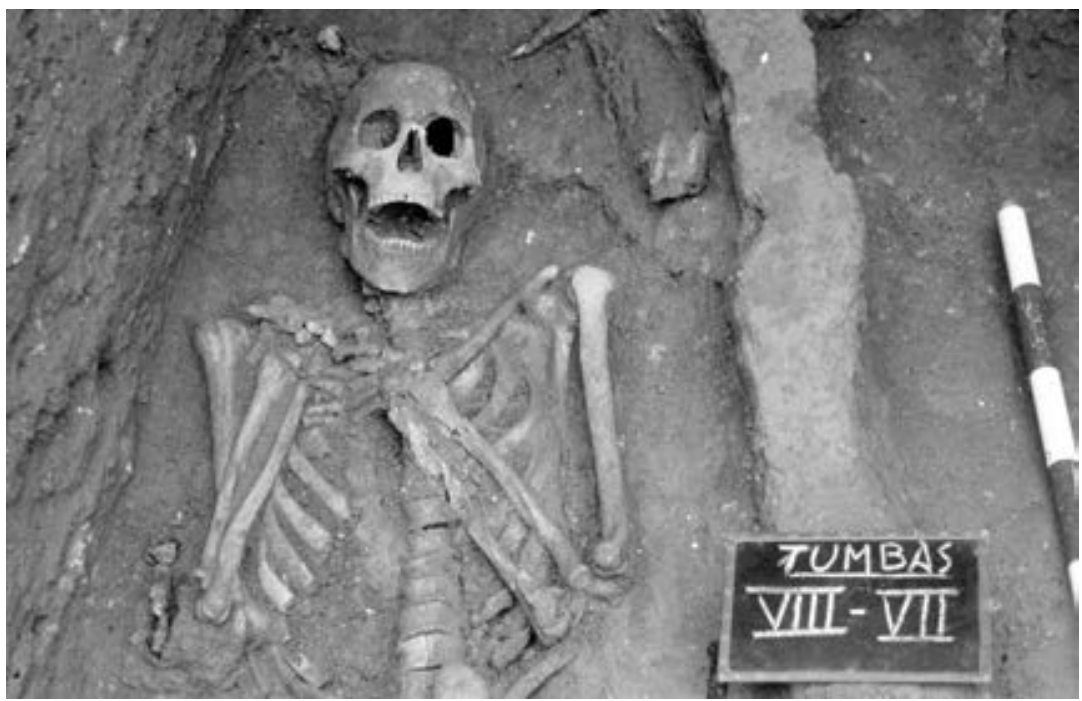

55. Tumba VIII. Donde está el jalón estaba la Tumba VII.

Otras observaciones de interés son la multitud de marcadores de actividad osteomuscular y un gran desgaste dental (véanse las pp. 221-222).

Junto a los restos humanos de esta tumba se halla un astrágalo posiblemente de équido.

Depósito funerario

1. Clavo de hierro. Sigla: 87.66/41.498-99 (todos los clavos siguientes poseen la misma sigla). Longitud conservada: $4,5 \mathrm{~cm}$. Diámetro: $12 \mathrm{~mm}$.

2. Clavo de hierro. Longitud conservada: $5,5 \mathrm{~cm}$. Diámetro: $1,2 \mathrm{~cm}$.

3. Vástago de clavo de hierro. Longitud conservada: $8,4 \mathrm{~cm}$. Diámetro: $1,2 \mathrm{~cm}$.

4. Clavo de hierro. Longitud conservada: $5,4 \mathrm{~cm}$. Diámetro: $8 \mathrm{~mm}$.

5. Clavo de hierro. Longitud conservada: $5,5 \mathrm{~cm}$. Diámetro: $1,1 \mathrm{~cm}$.

6. Clavo de hierro. Longitud conservada: $3,6 \mathrm{~cm}$. Diámetro: $1,2 \mathrm{~cm}$.

7. Clavo de bronce. Sigla: 87.66/ 41.499 (la misma sigla para el siguiente). Longitud: $1,5 \mathrm{~cm}$. Anchura de la cabeza: $1,3 \mathrm{~cm}$. Vástago de sección cuadrada. 
Clavo de bronce. Longitud: 1,4 cm. Anchura de la cabeza: 1,4 cm. La forma de la cabeza es algo facetada y en punta. La sección del vástago es cuadrangular.

Moneda de Claudio II († 270) (n. ${ }^{\circ} 111$ del Monetario del Ayuntamiento). Sigla: 87.66/33.141. (Ya se ha comentado arriba la circunstancia estratigráfica de esta moneda, que puede que no deba interpretarse como contexto funerario, al menos de estas tumbas).

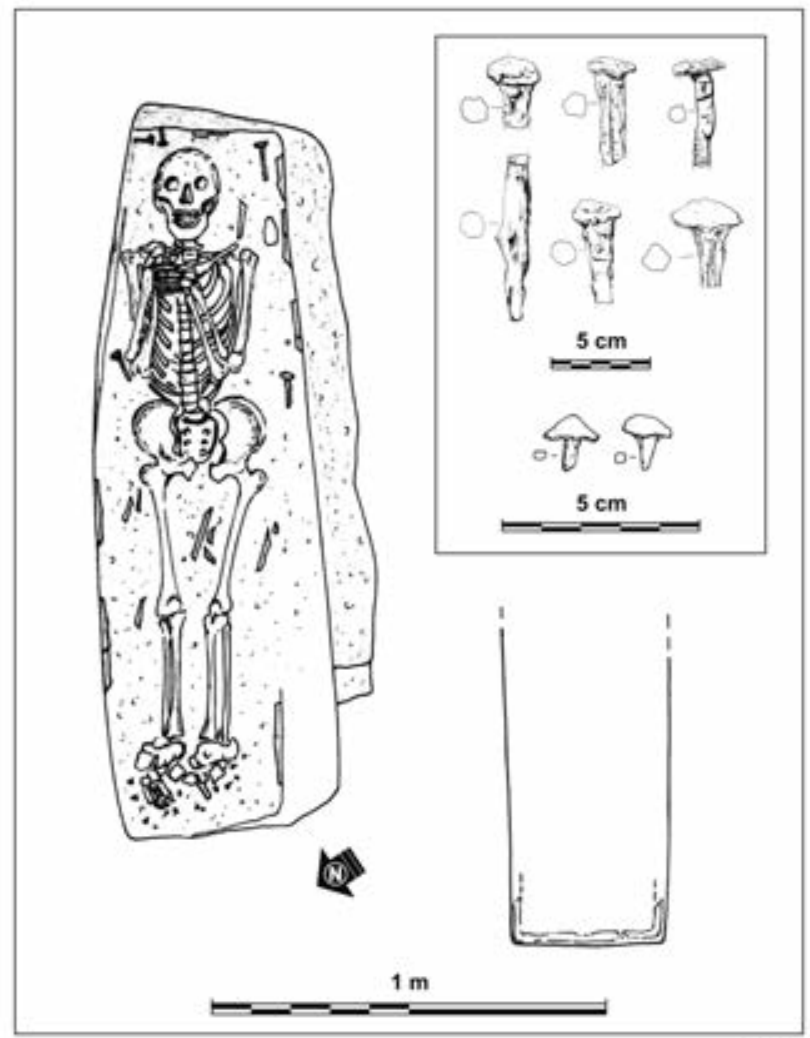

T-8

56. Tumba VIII. 


\section{Observación a las cubiertas de las Tumbas VII y VIII}

Ninguna de las dos contaba con tejas. El ataúd fue directamente a la fosa y parece que fueron cubiertas con tierra. No obstante, esta modestia en el ritual puede deberse a la posible desaparición de una estructura mayor que les diera cobijo, pero de la que no se conservaba nada más que algunas piedras de mediano tamaño.

\section{Tumba IX}

Estaba constituida por la inhumación de un varón de 26 a 32 años de edad y con una talla aproximada de 160 a $170 \mathrm{~cm}$, en una sepultura en fosa escalonada como las anteriores. La posición era decúbito supino, con la cabeza hacia el noroeste. En el curso de su excavación pudo conocerse el proceso seguido en esta inhumación: la fosa se excavó hasta tropezar con un muro de sillares de la domus de época fundacional, se desmontó alguna piedra de este y se depositó sobre él y sobre el basurero ya citado de época de Claudio y Nerón. Conservaba restos de clavos y de madera del ataúd.

El enterramiento estaba cubierto por tegulae en disposición plana, unas sobre otras, pero no puede descartarse la posibilidad de que se tratara de una cobertura a doble vertiente cuyo hundimiento se produjo al depositarse tierras sobre la estructura, ya que sobre las tegulae había un espacio vacío. La cota del fondo de la fosa era 200.040.

Otras observaciones de gran interés están constituidas por marcadores de actividad osteomuscular o de estrés óseo en distintas localizaciones tanto en la extremidad superior como en la inferior y un alto grado de desgaste dental (véanse las pp. 227-229).

\section{Depósito funerario}

Se recogieron pequeños clavos en la zona de los pies que habrían formado parte del calzado que llevaba el cadáver cuando fue inhumado y otros de la caja de madera.

1. Clavo de hierro. Sigla: $87.66 / 41.500$. Longitud conservada: 9,8 $\mathrm{cm}$. Diámetro del vástago: $1,2 \mathrm{~cm}$.

2. Clavo de hierro. La misma sigla que el anterior. Longitud conservada: $5 \mathrm{~cm}$. Anchura de la cabeza: $5 \mathrm{~cm}$. Diámetro del vástago: $1,3 \mathrm{~cm}$.

3. Clavo de hierro. La misma sigla. Longitud conservada: $6 \mathrm{~cm}$. Diámetro del vástago: $9 \mathrm{~mm}$. Anchura de la cabeza: $2,5 \mathrm{~cm}$. 


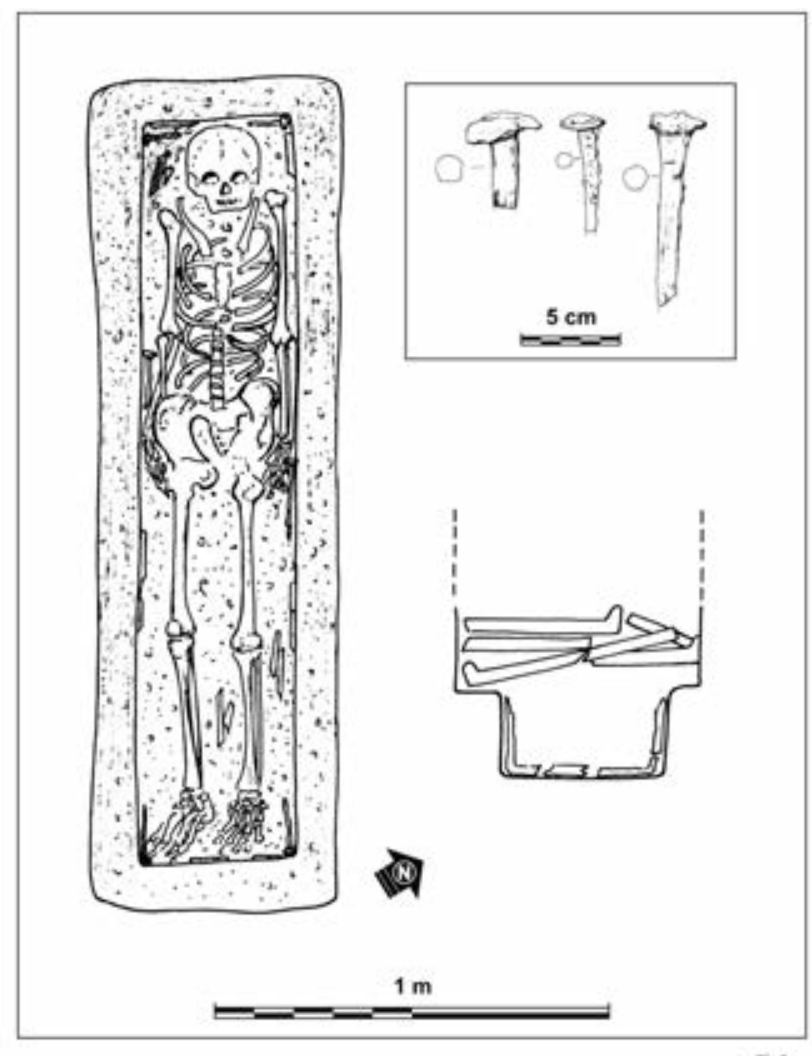

T.9

57. Tumba IX.

\section{Tumba X}

Fue la única sepultura que pudo documentarse en el solar de los n. ${ }^{\text {os }} 28$ 30 de la manzana, y constituyó el único excavado de época romana, siendo también el más cercano a la calle actual, es decir, el más meridional. No puede descartarse que hubiera más tumbas porque no pudo comprobarse. La excavación tenía una fecha límite, ocupándonos la mayor parte del periodo concedido en la documentación del cementerio islámico que le precedió en el proceso por estar lógicamente a menor profundidad y ser el primero a documentar. En este caso tuvieron más suerte los enterramientos más modernos. 
Era la inhumación de una mujer de 33 a 46 años de edad y con una talla estimada de 145 a $155 \mathrm{~cm}$, que estaba en decúbito prono con los pies en posición cruzada como en la Tumba VII. No se constató una estructura funeraria semejante a los otros casos. Sin embargo, se conservaban una serie de piedras angulosas junto al cadáver, no sobre él. Fondo de la fosa: 200.44 m. s. n. m. Presenta intenso grado de desgaste dental, desarrollo de la cresta glútea asociado al tránsito por una accidentada orografía e indicaciones de acuclillamiento o marcha prolongada por terrenos irregulares (véanse las pp. 232-234).

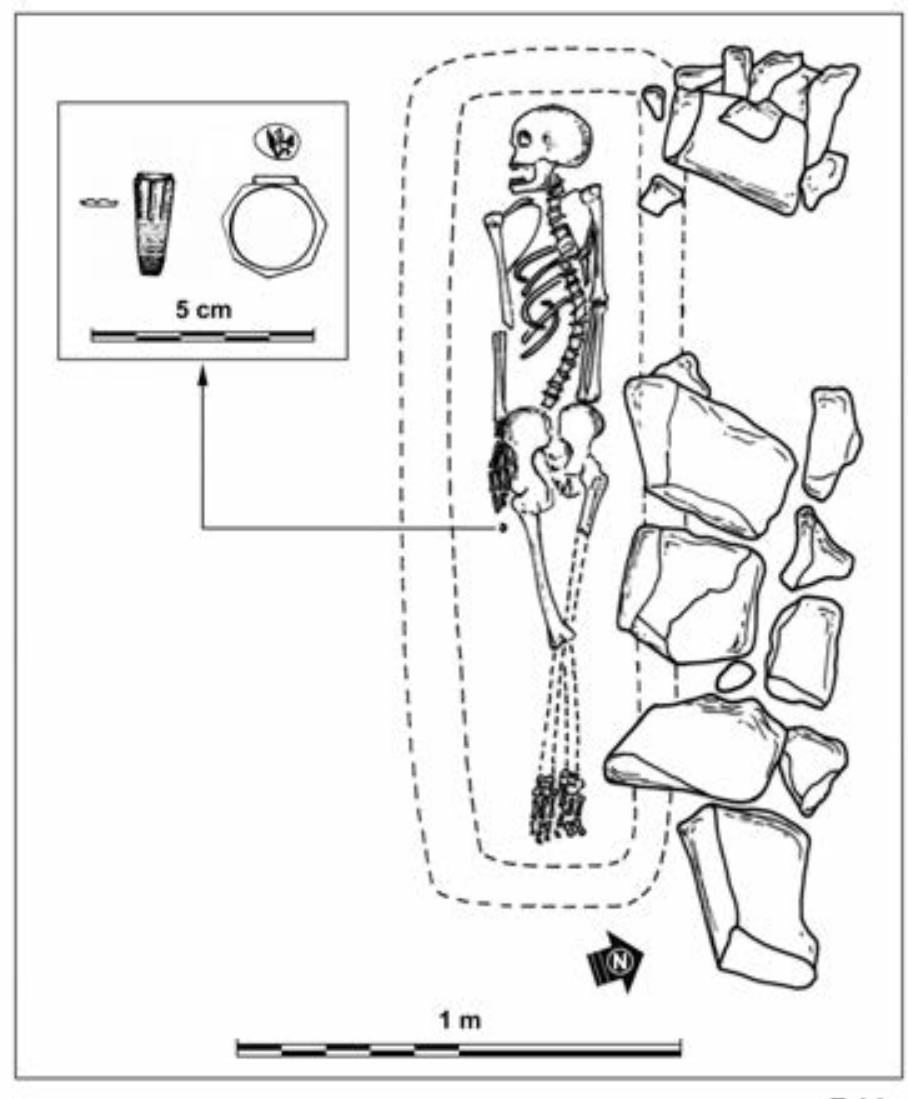

$\mathrm{T}-14$

58. Tumba X. 


\section{Depósito funerario}

En las proximidades de la mano izquierda apareció un anillo de bronce de forma poligonal en la parte exterior, mientras que la interior es circular. Tiene un sello cuyo motivo está formado por un gallo y una palma (o espiga).

Anillo de bronce. Sigla: 90.66-1513. Profundidad: $240 \mathrm{~cm}$. (Lám. XVIII b. 3). Museo de Zaragoza.
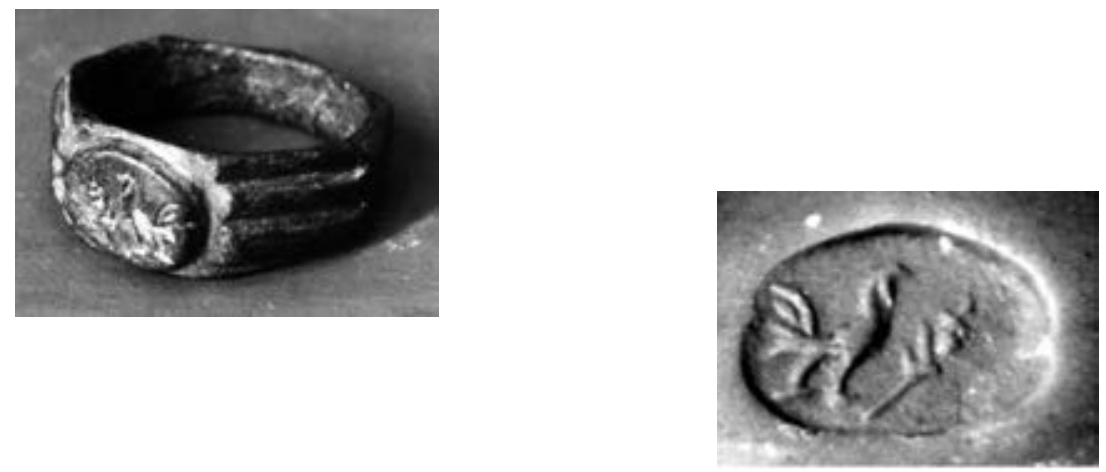

59. Anillo de bronce.

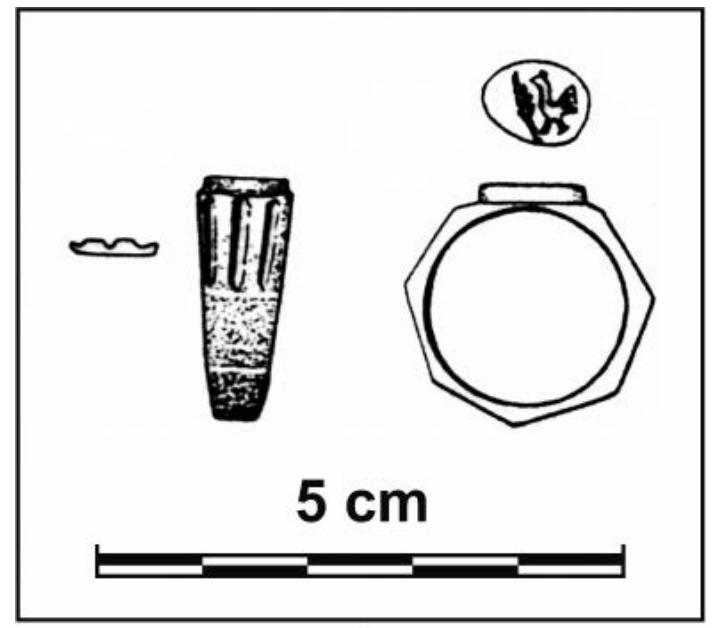

60. Anillo de bronce. 
Bibliografía: AA. VV., 1991, Arqueología de Zaragoza: 100 imágenes representativas, $n{ }^{\circ}$ de catálogo: 39 . Anillo de bronce circular en el interior y poligonal en la zona visible. Sello de forma oval con decoración en negativo de un gallo de perfil, y de pie sobre una palma. Datación cronológica: siglo III d. de C. Se conocen paralelos de entalles con este tema (Casal, 1979, 1107; 1990, 175).

\section{Tumba XI}

Se trataba de una inhumación de varón de 24 a 28 años y con una talla de 168 a $172 \mathrm{~cm}$, con la mano derecha sobre el pecho y la izquierda doblada por el codo y replegada sobre el hombro. Los restos óseos estaban en muy mal estado de conservación, y habían sido depositados en una sepultura de fosa escalonada. Como en el caso anterior, también había un vacío causado por el plegamiento de las tegulae de la cubierta. Al eliminar la primera capa de estas, todas ellas fragmentadas, había otra de piezas enteras. El modo de cubrirla recuerda mucho a la cubierta del monumento funerario. La estructura así formada, que distaba casi diez metros en línea recta del bustum, plantea

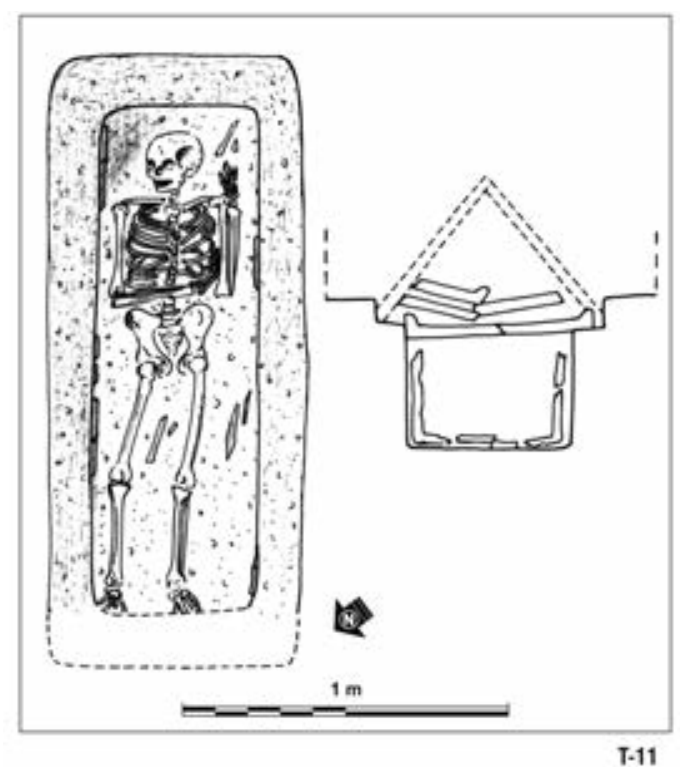

61. Tumba XI. 
la duda de cuál de ellos fue el primero, sin solución posible. No obstante, la fábrica usada en ambos, con un rito tan diferente, es muy similar. Conservaba algún clavo del ataúd. Cota: 199.220.

Otras observaciones: marcadores de estrés o de actividad osteomuscular entre otras (véanse las pp. 237-238).

\section{Tumba XII}

Está muy próxima a la anterior, por lo que pudiera tratarse de un enterramiento efectuado muy próximo también en el tiempo.

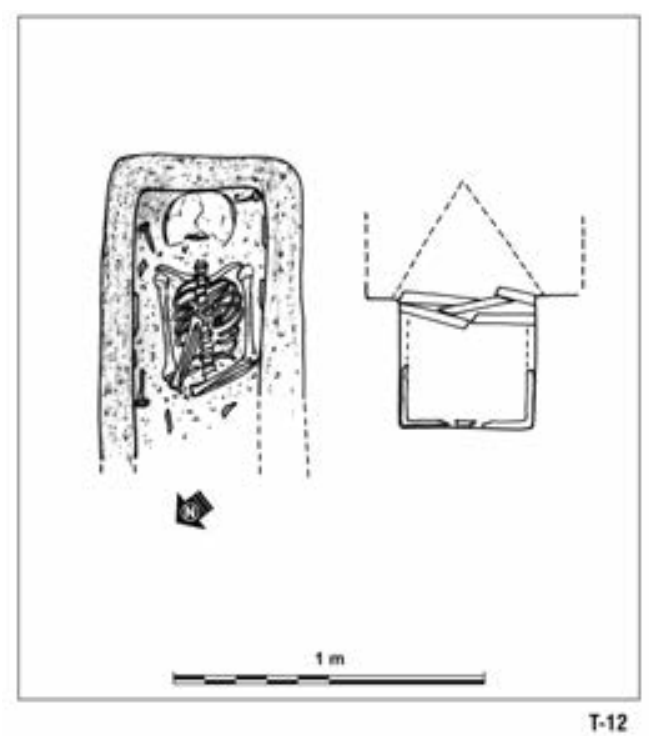

62. Tumba XII.

Era la inhumación de una mujer de 59 a 71 años de edad, con restos de ataúd y clavos del mismo. La fosa tiene las características similares a las anteriores, si bien su nivel superior estaba arrasado por remociones posteriores. Su excavación fue incompleta, puesto que el enterramiento se introducía en la zona de las extremidades inferiores en el corte del solar contiguo. El brazo 
derecho presentaba el antebrazo hacia arriba y la mano en el pecho, mientras que el brazo izquierdo se disponía en ángulo recto con la mano sobre el tórax. El cráneo estaba muy deteriorado. También se recogió algún clavo de hierro (véanse las pp. 241-242).

Cota: 199.740 .

\section{Tumba XIII}

Era la inhumación de una mujer de 33 a 46 años de edad y con una talla de 140 a $150 \mathrm{~cm}$, depositada en una sepultura en fosa con escalón. Conservaba restos de la caja de madera y clavos de hierro de la misma. La fosa tiene las mismas características que las descritas anteriormente. Cota: 200.191.

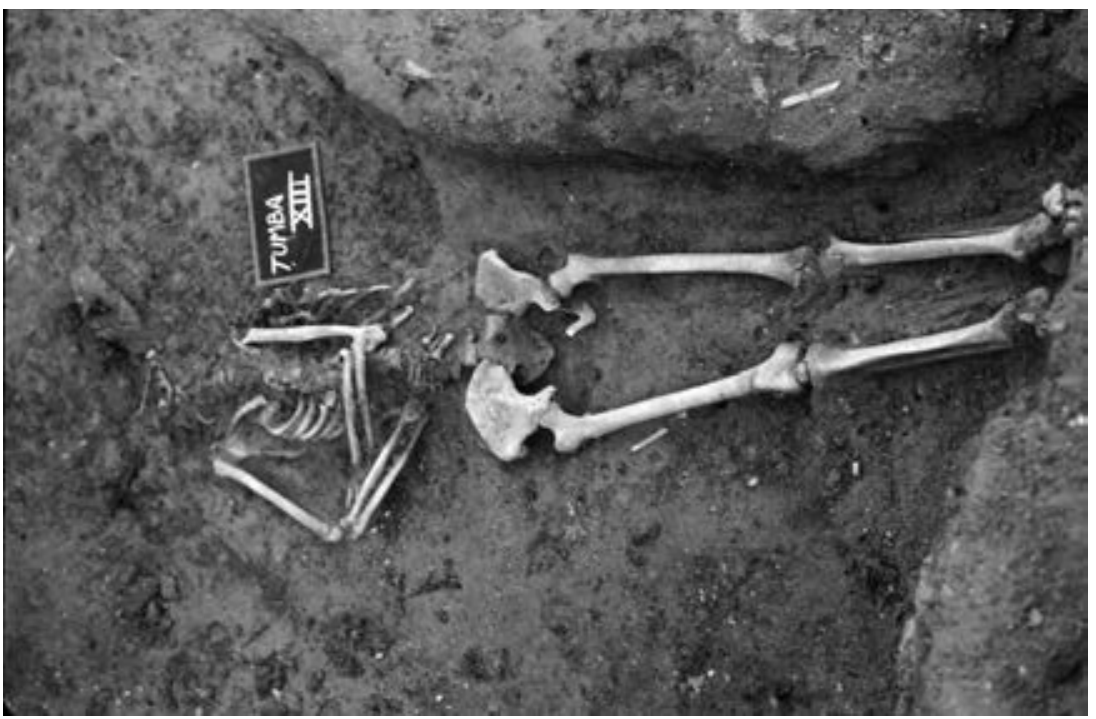

63. Tumba XIII.

Alguna observación de especial interés es la constituida por las huellas que detectan el acuclillamiento o la marcha prolongada por terrenos irregulares, al igual que ocurría con la mujer de la Tumba X (véanse las pp. 246-249). 


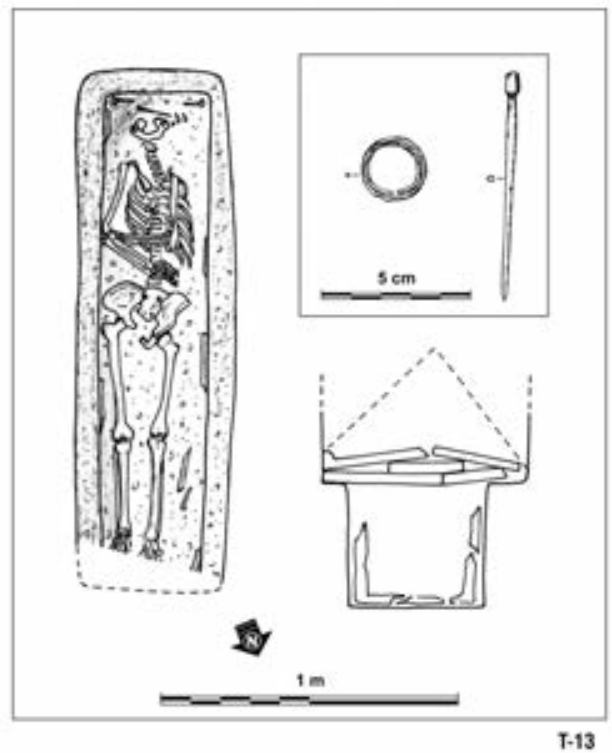

64. Tumba XIII.

\section{Depósito funerario}

Llevaba dos aritos de bronce en el dedo corazón de la mano derecha, y conservaba un alfiler (acus crinalis) en la zona de la cabeza - que muy probablemente le habría sujetado el cabello- y su cráneo estaba muy mal conservado.

En lo que respecta al alfiler de pelo, hay numerosos testimonios de la presencia en tumbas de inhumación de agujas en hueso o metal, situadas cerca del cráneo (Beal, 1983, 183, nn. 5 y 6; Beltrán de Heredia, 2007, 40), y también se han encontrado en la zona inferior de las sepulturas: en este caso puede suponerse que se habrán desplazado de su lugar original o bien que fueron depositados como elementos de ajuar personal en algún estuche o cajita. El uso de estos alfileres para sujetar el cabello está atestiguado, por otra parte, en retratos monetales (Helena, mujer de Constancio Cloro, Licinia Eudoxia, mujer de Valentiniano III, o en cabellos postizos del Fayum que conservaban estos objetos enredados en ellos). 


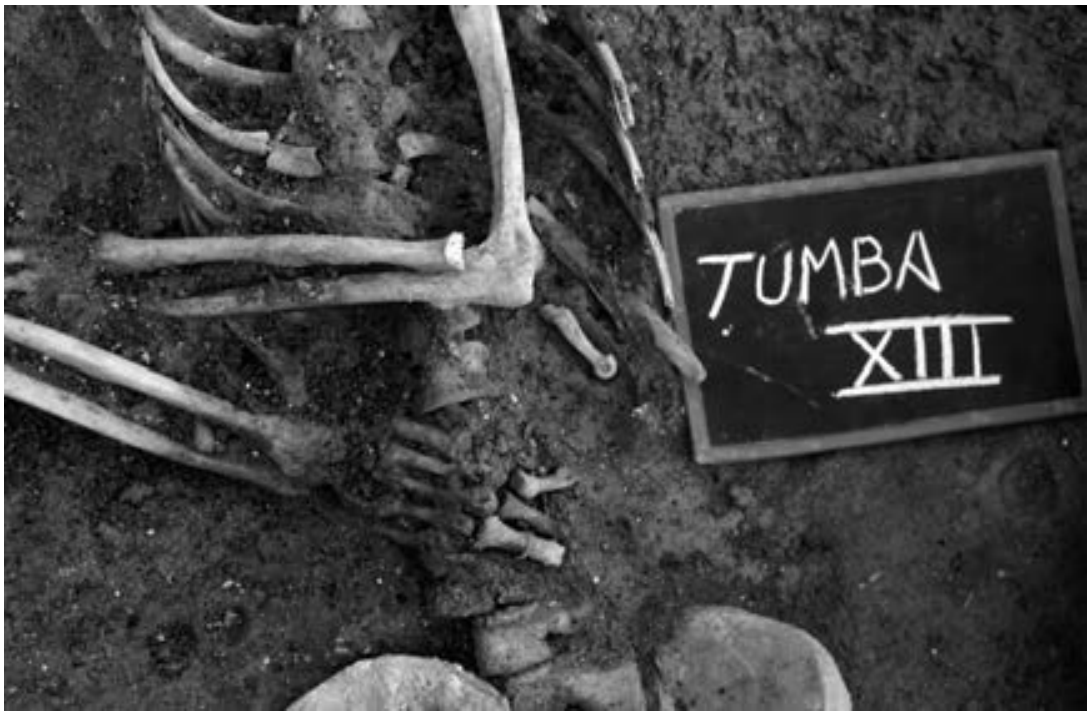

65. Puede observarse un aro de bronce en una falange.

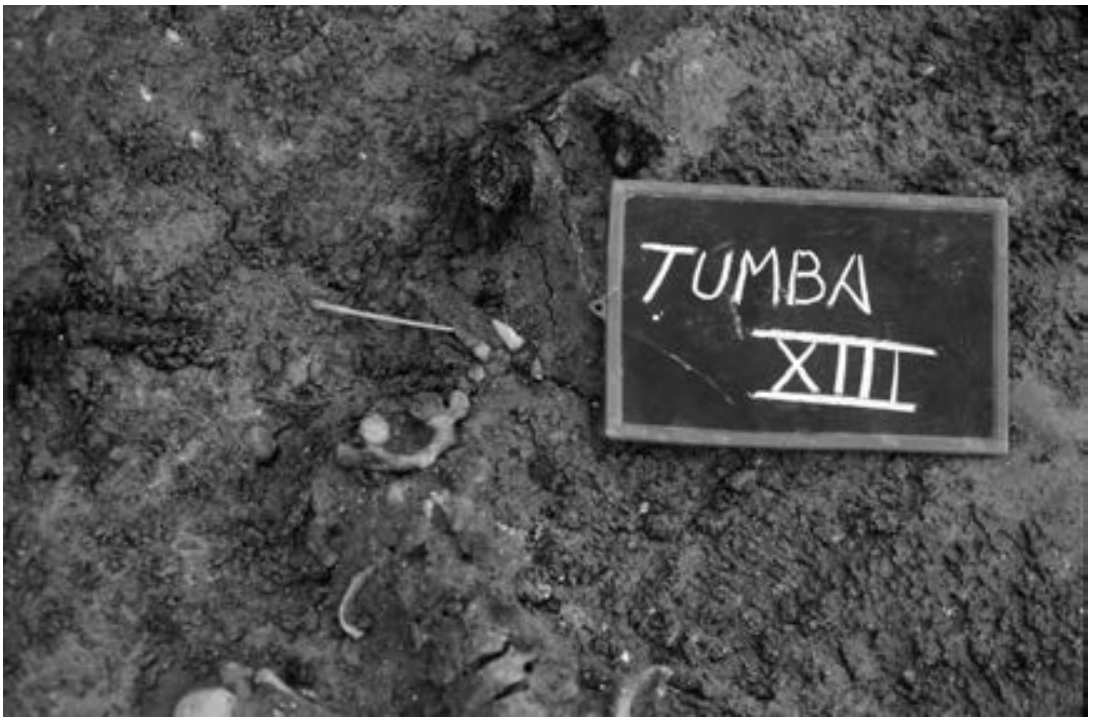

66. El cráneo casi había desaparecido pero en la zona que correspondería a la nuca se conservaba un acus crinalis. 
1. Acus crinalis. Sigla: $87.66 / 41.501$. Longitud: $7,8 \mathrm{~cm}$. Según la tipología de Beal se incluiría en el Tipo A XX.

2. Aritos de bronce. Sigla: 87.66/ 41.502-41.503.

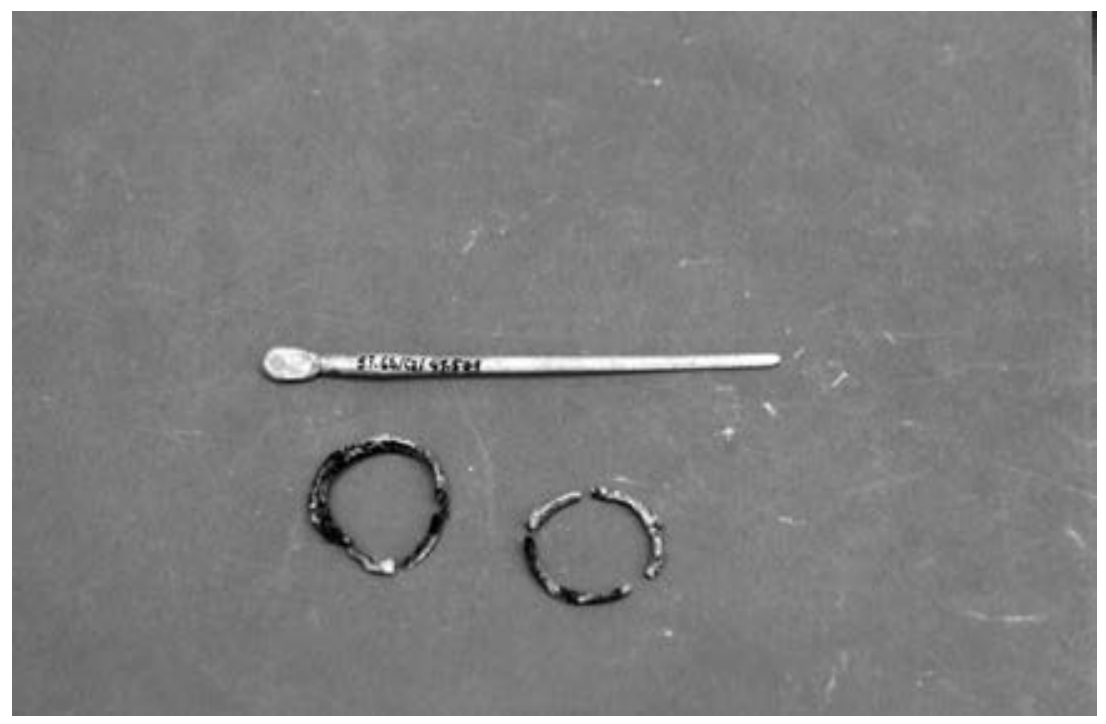

67. Objetos personales de la mujer de la Tumba XIII.

Observaciones al grupo de inhumaciones del siglo III

Las inhumaciones forman un grupo cuya relación desconocemos: seis hombres jóvenes, una mujer anciana, otra adulta, un niño de dos a cuatro años, un neonato y un feto. Como características comunes se encuentra la situación estratigráfica, una tipología muy similar a todas excepto las de los recién nacidos; pero, en particular, sobresalen las características antropológicas apreciadas en los varones.

Son mayoritariamente adultos jóvenes que presentan marcados signos de estrés y una actividad osteomuscular, según la valoración a partir de los criterios de Hawkey y Merbs en sus máximos grados. Se aprecian marcadores osteomusculares a nivel de la extremidad superior relacionados con la carga de peso y/o lanzamiento de objetos, y desplazamiento de vaivén del miem- 
bro hacia atrás y al pecho opuesto. En las extremidades inferiores presentan marcadores osteomusculares relacionados con marcha prolongada, largos periodos de bipedestación, tránsito por una accidentada orografía y mantenimiento del equilibrio individual en condiciones inestables, realizar largas caminatas por terrenos muy accidentados y el frecuente impacto del pie sobre el suelo, continuados esfuerzos tensionales, como, por ejemplo, torceduras.

Se ha advertido también un importante desgaste dental que se ha atribuido, «no solo debido a la atrición de la dieta consumida, sino a un bruxismo ocasionado tanto por el estrés que estos individuos se supone que soportaban como por las actividades que desarrollaban, ocasionando un desgaste dental tanto en las caras oclusales de premolares y molares como en los bordes incisales de los dientes anteriores. Este tipo de desgaste de todas las piezas dentales se sabe que está ocasionado por un bruxismo y no por la dieta ${ }^{30}$

La edad de la muerte establecida sin lugar a dudas en la juventud plena de los individuos varones es seguramente el hecho más destacable. ${ }^{31}$

\section{Otras tumbas posteriores}

La fase de inhumaciones prosigue y es posible que no hubiera interrupciones. También pudo ser esta la causa del deterioro de algunas tumbas del grupo del siglo III, fenómeno al que ya se ha hecho referencia. En concreto hay dos inhumaciones del solar Predicadores, 24-26, que por haberse excavado al comienzo de los trabajos recibieron numeración arábiga como las tumbas islámicas. Ambas conservaban pequeños sillares y el fondo de la fosa estaba constituido por un lecho de gravilla. Las dos fueron seleccionadas para ser analizados sus restos por radiocarbono, ya que carecían de contexto y su ubicación cronológica era imposible. Una de ellas (Tumba 132) contenía una inhumación en decúbito supino y con orientación E-O; la profundidad era 200.14 m. s. n. m. y proporcionó una datación en el siglo $\mathrm{V}$ $(439 \pm 30)$. La segunda (Tumba 5) también presentaba los restos E-W y en

30 Estos datos han sido extraídos del Informe Paleoantropológico (véanse las pp. 251-252).

31 Este constituiría en sí mismo motivo para otro estudio. Cf. Al respecto, Y. Le Bohec (1987), donde se aborda «la edad de la muerte» precisamente en medios militares, en este caso, soldados de la III Legión Augusta. 
decúbito supino, a una profundidad de 200.26 m. s. n. m. y estaba seccionada por un enterramiento musulmán a la altura del tórax. Su datación radiocarbónica debe desecharse $(139 \pm 35)$ por posible contaminación al cavarse la fosa de la fase del cementerio islámico. ${ }^{32}$

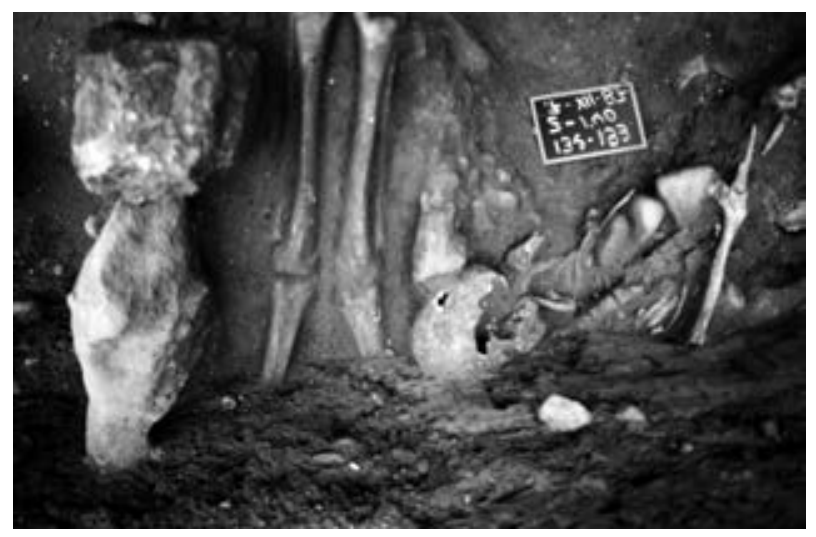

68. Detalle de dos fases de inhumaciones posteriores al grupo del siglo III: tardoantigua a la izquierda e islámica cruzada.

\section{Fosa con caballo}

Entre las Tumbas IV, VI y V se encontró una fosa con el enterramiento de un équido ( $\mathrm{n}{ }^{\circ}$ de Inventario: 7.987). El significado de este hecho puede ser objeto de controversia, pero su situación estratigráfica en el contexto de las tumbas del siglo III no ofrecía duda alguna. ${ }^{33}$ Se trata de un conjunto de 27 huesos pertenecientes a Equus Caballus, además de otros numerosos que no se han podido identificar. No se encontraba el cráneo, pero las extremidades anteriores y posteriores parecen estar en conexión anatómica.

32 Hay otras dos tumbas datadas también por radiocarbono: la $78(669 \pm 30)$, que rompe el ángulo noroeste de la edícula funeraria, y la 89, de época islámica $(929 \pm 30)$ que pertenece a un hombre decapitado. Respecto a la primera debe considerarse una datación más tardía que la ofrecida por el radiocarbono: su adscripción a la época islámica no plantea dudas, ya que el enterramiento era musulmán por sus características; en esta ocasión el rito debe anteponerse ante una datación absoluta improbable.

33 Un análisis preliminar ha sido realizado por Fernanda Blasco cuyos datos, en espera del resultado definitivo, son los que aquí aportamos. 
En la necrópolis de Can Trullás (Granollers, Barcelona) se vinculó el hallazgo de restos de tres équidos con un sacrificio funerario de animales de compañía relacionados con enterramientos humanos, pero posteriormente han surgido opiniones contrarias a este significado, argumentándose para ello tanto razones estratigráficas como culturales. En segundo lugar, hay quien apunta la inexistencia de paralelos similares de sacrificios funerarios de équidos en época romana (Uscatescu, 2004, 93).

En el caso del équido inhumado entre el grupo de tumbas romanas que nos ocupa, no hay duda alguna en cuanto a la coetaneidad estratigráfica con el resto de los enterramientos. La profundidad $(200.29$ m. s. n. m.) está entre la de las tumbas infantiles V (200.43) y VI (200.64) y la de las Tumbas IV (199.24) y VII y VIII (199.66). Respecto a esta última Tumba VIII, conviene recordar que, junto a los huesos humanos, se recogió un astrágalo de caballo que desconocemos por ahora si perteneció al mismo animal.

$\mathrm{Al}$ sacrificio de caballos se le ha otorgado carácter psicopompo (Van Doorselaer, 1967, 120; Allain et al., 1992, 120), pero su hallazgo en contextos funerarios continúa siendo controvertido pudiéndose adscribir a sacrificios rituales o incluso que se utilizaran estos mismos espacios para deshacerse de ellos por ser animales que no se consumían en esta época (Colominas, 2007, 94-96).

Recientemente se han estudiado restos inhumados de équido en la necrópolis de la vía funeraria de la plaza Villa de Madrid (Barcelona) que han dado lugar a interesantes conclusiones. Los restos de estos animales, que se hallaron en todas las unidades funerarias, aparecieron sacrificados en algunos casos en conexión anatómica y en otros con señales evidentes de haber sido descuartizados. Al igual que en el caso de los cánidos, los équidos no parece que se consumieran (Beltrán de Heredia, 2007, 49; Colominas, 2007, 86-87).

El carácter militar que pretendemos atribuir a estas gentes puede sugerir una hipótesis atractiva de carácter religioso para el enterramiento sin cabeza de este caballo entre las tumbas humanas. En el ámbito militar gozaba de gran importancia una celebración, el Equus October, ${ }^{34}$ fiesta en la cual

34 Debemos esta hipótesis a Gonzalo Fontana (Departamento de Ciencias de la Antigüedad, Universidad de Zaragoza) quien está trabajando sobre esta cuestión en la actualidad a partir de este hallazgo. 
se sacrificaba al dios Marte un caballo, al que se cortaba la cabeza y la cola. También como hipótesis explicativa a este hecho, debe sugerirse el carácter funerario del caballo, como signo de viaje al más allá: un carro tirado por caballos conducía hacia el ocaso y hacia el amanecer al sol.

\section{Hallazgos residuales}

Parece interesante dar a conocer un breve catálogo de material residual procedente de enterramientos destruidos y otros de contextos que originariamente habrían sido ofrendas funerarias distorsionadas y dañadas por posteriores fosas u otras actividades. Se trata de algunas piezas que pudieron pertenecer al cementerio romano, desde objetos de adorno personal hasta otros utilizados en las ceremonias fúnebres, que estaban en el contexto arqueológico que cubría las sepulturas (c2).

Destacan fragmentos de botellas y vasitos de vidrio; un arito de oro (1,6 $\mathrm{cm}$ de diámetro; lám. 69), un fragmento de lámina de oro de forma arqueada $\left(8,5\right.$ x 2,5 cm; lám. 69 y 72) (Galve, 1991, n. ${ }^{\circ} 45 ; 1993$, n. $\left.{ }^{\circ} 25\right)$ y un acus crinalis con la cabeza forrada de oro ${ }^{35}$ que apareció entre un conjunto de agujas y una moneda de Galieno (lám. 71). En bronce hay que hacer referencia a un soporte mobiliario con forma de garra de felino (lám. 70), una fíbula (lám. 70) y una pequeña lucerna con dos picos con asa anular con hoja acorazonada sobre ella (lám. 70; Menzel 89.5.6). En este nivel, se recuperaron abundantes agujas de todo tipo en hueso (lám. 71).

Otro hallazgo de interés está constituido por un conjunto de monedas del siglo IV (fechadas entre Constantino I y Magno Máximo) que todavía se encontraban en una bolsita de cuero (n. ${ }^{\text {os: }}$ 131, 133, 134, 135, 136 y 137 del Monetario del Ayuntamiento; cota: 200.66).

35 Beal (1983), 202-203 hace referencia a un tipo de agujas (A XX, 14) que tiene la cabeza en forma de bulbo y que está cubierta de una capa de oro cuyo perfil particular de la cima facilita la adherencia y le impide resbalar. El tipo está bien atestiguado en Grecia e Italia, debiendo desarrollarse en Galia hacia finales del siglo II, llegando su uso hasta el siglo IV. Además de sujetar, no hay duda de que la cabecita dorada surgiendo del cabello sería muy vistosa. 


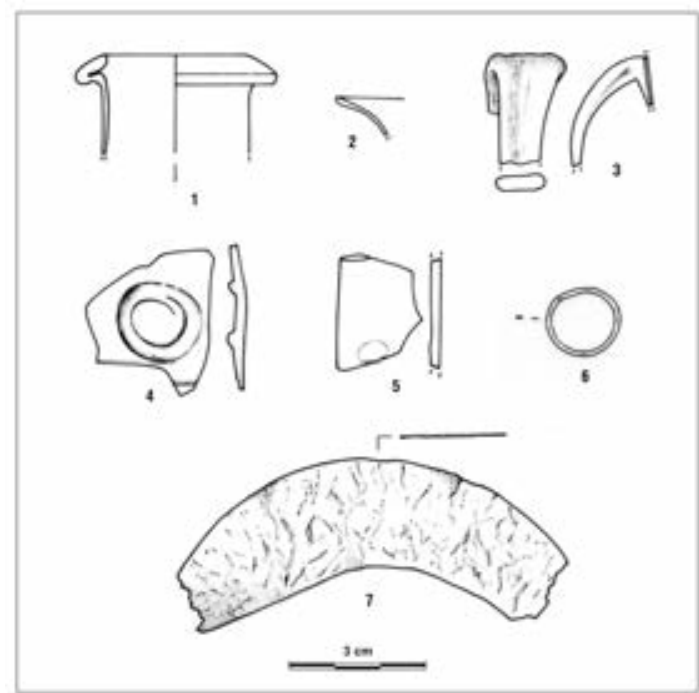

69. 1. Botella de vidrio color violeta. $87.66 / 30.606$. 2. Botella de vidrio transparente. 87.66/30.607. 3. Vasito de vidrio translúcido. 87.66/30.608. 4. Fondo de botella de vidrio. 87.66/30.609. 5. Asa de vidrio translúcido. 87.66/30.610. 6. Arito plano de oro. 87.66/10.629. 7. Lámina de oro. 87.66/15.441.

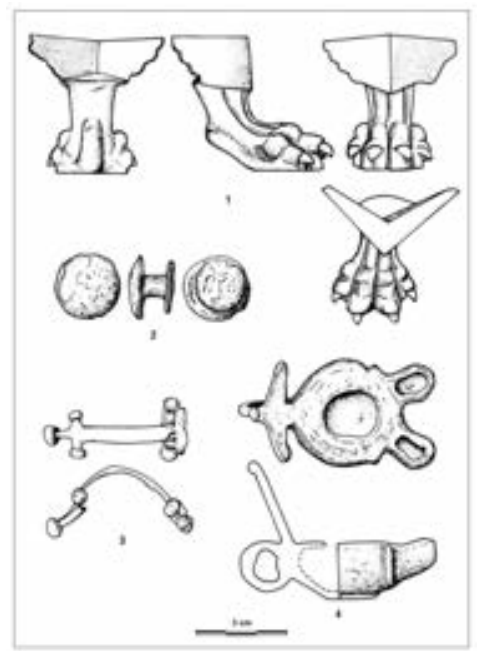

70. 1. Soporte mobiliario de bronce con garra de felino. 87.66/15.408. 2. Botón de bronce. 3. Fíbula de bronce. 87.66/15.387. 4. Lucerna de bronce con dos picos. 87.66/40.851. 


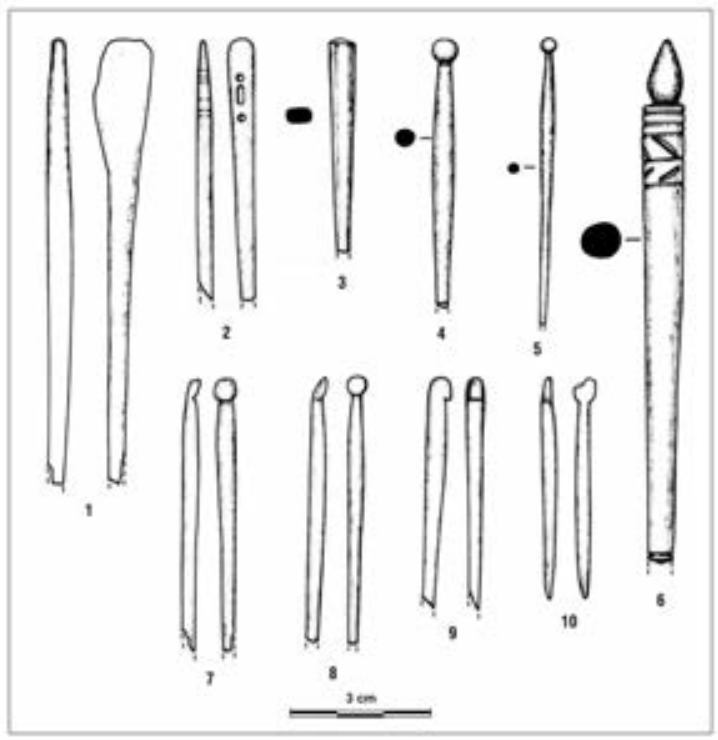

71. 1. Alfiler de cabeza moldurada. 89.66/4.328. 2. Alfiler de cabeza redondeada. 89.66/4.367. 3. Acus crinalis con lámina de oro en la cabeza. 89.66/2.131. 4. Aguja de bolillo (de huso). 89.66/4.329. 5. Espátula. 89.66/4.332. 6. Espátula. 89.66/4.333. 7. Espátula. 89.66/4.334. 8. Espátula. 89.66/6.332. 9. Objeto cilíndrico sin identificar. 89.66/4.419. 10. Aguja de coser. 89.66/4.330.

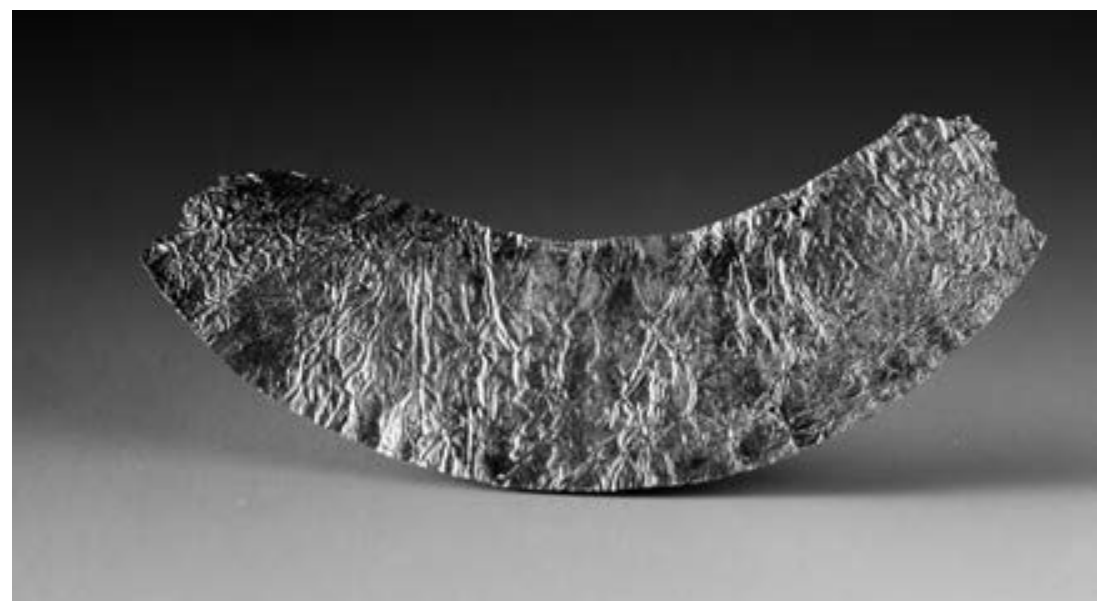

72. Lámina de oro. 


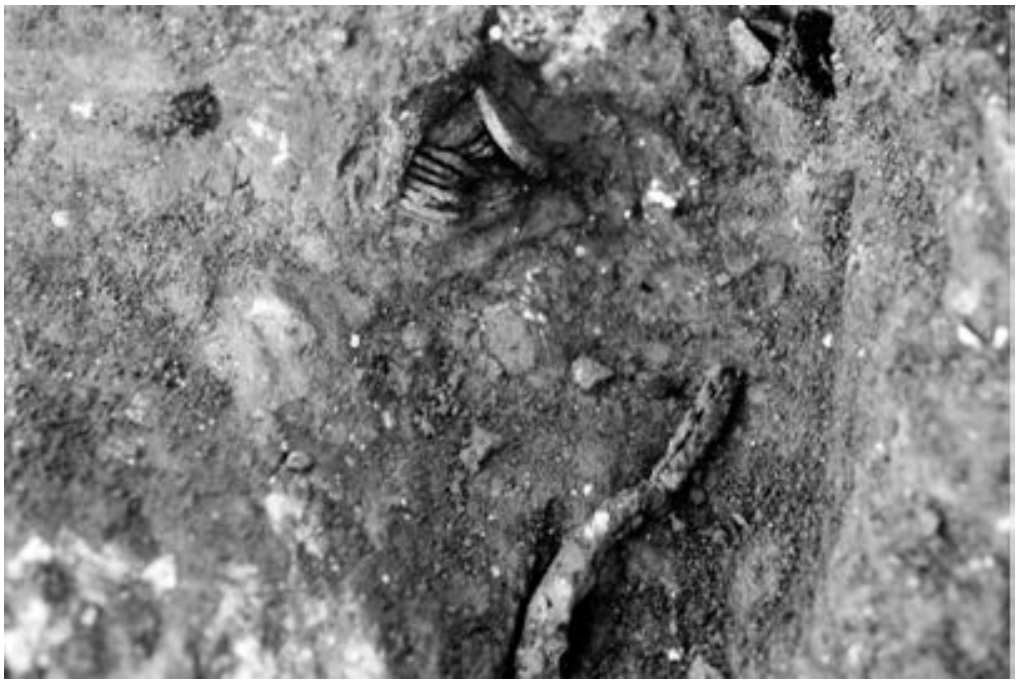

73. Hallazgo de los restos de una bolsita de cuero llena de monedas del siglo IV.

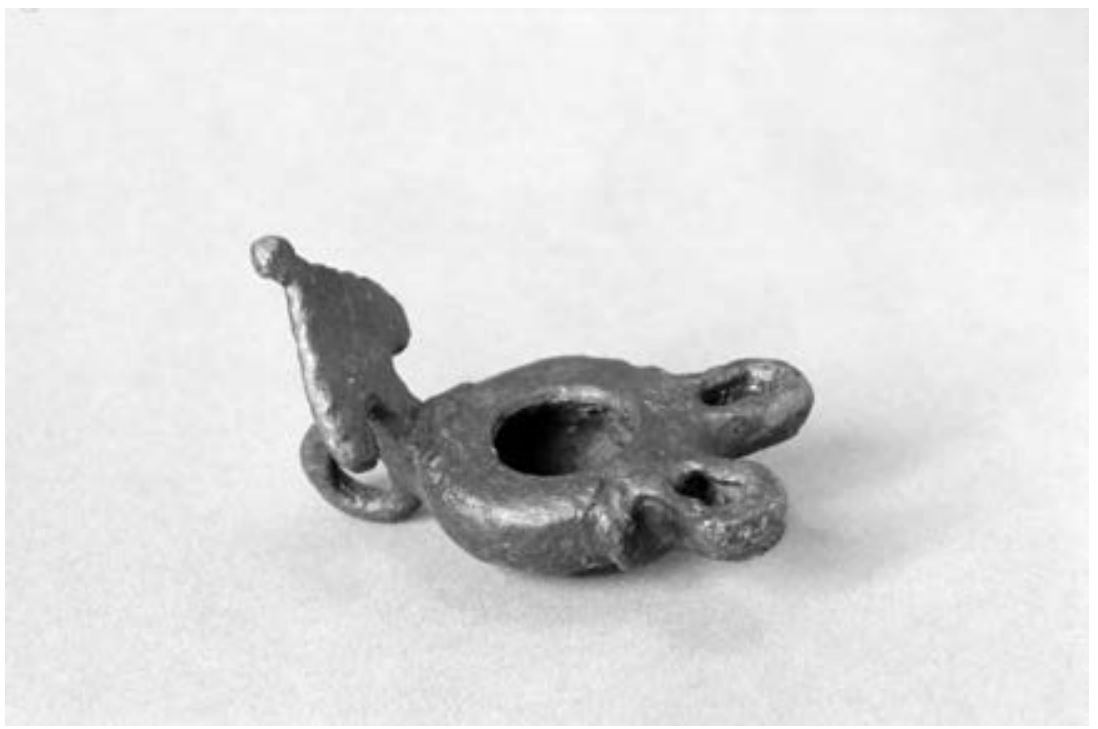

74. Lucerna de bronce. 


\section{CAPÍTULO III EL MONUMENTO FUNERARIO INCINERACIÓN I}

[...] entre los historiadores, los arqueólogos somos los más afortunados.

(A. Fuentes, 2001) $)^{36}$

Nuestro trabajo, si el azar lo propicia, puede ser especialmente emocionante cuando se nos brinda la oportunidad de establecer contacto físico con unos restos humanos que han permanecido mudos desde el momento en el que sus seres queridos los acompañaron en el último adiós. Pero la comprensión del arqueólogo no está condicionada de antemano, sino que va formándose con la cuidadosa limpieza de los restos ante lo imprevisible.

Sentimientos parecidos fueron los que vivimos con la experiencia de la excavación (y destrucción al fin y al cabo) de este pequeño monumento. En este caso se habían preservado la arquitectura, modestísima desde luego, y el rito, hecho demasiado infrecuente en la arqueología funeraria, aspecto de la investigación arqueológica en el que es habitual la dedicación de los especialistas al contenido artístico, teniendo que prescindir del contenido real, muchas veces por la expoliación que han sufrido estos edificios.

El pequeño mausoleo estaba casi completo, además de tener intacta la sepultura, hecho en sí raro: solamente le faltaba parte del volteo de la bóveda y parte del alzado del ángulo posterior occidental, roto por un enterramiento de época islámica. También estaba afectada su fachada anterior a nivel del suelo de la edícula.

36 Prólogo al excelente trabajo de R. González Villaescusa (2001). 


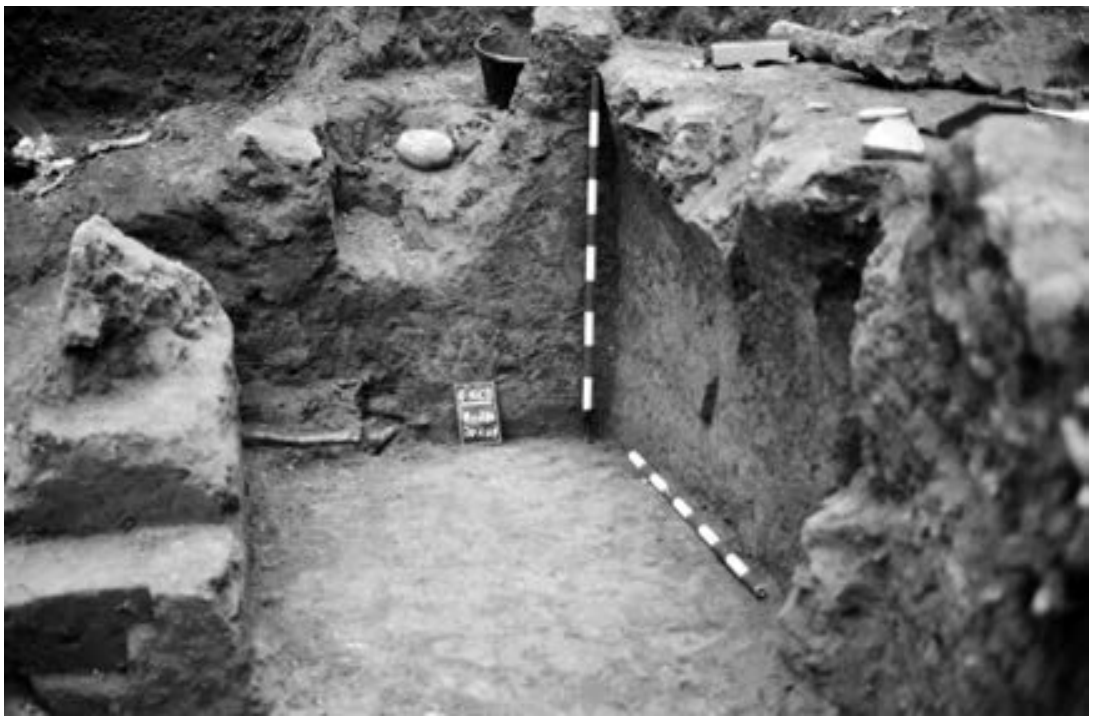

75. Interior del edículo. Al fondo, fémur de la Tumba 78 del cementerio musulmán.

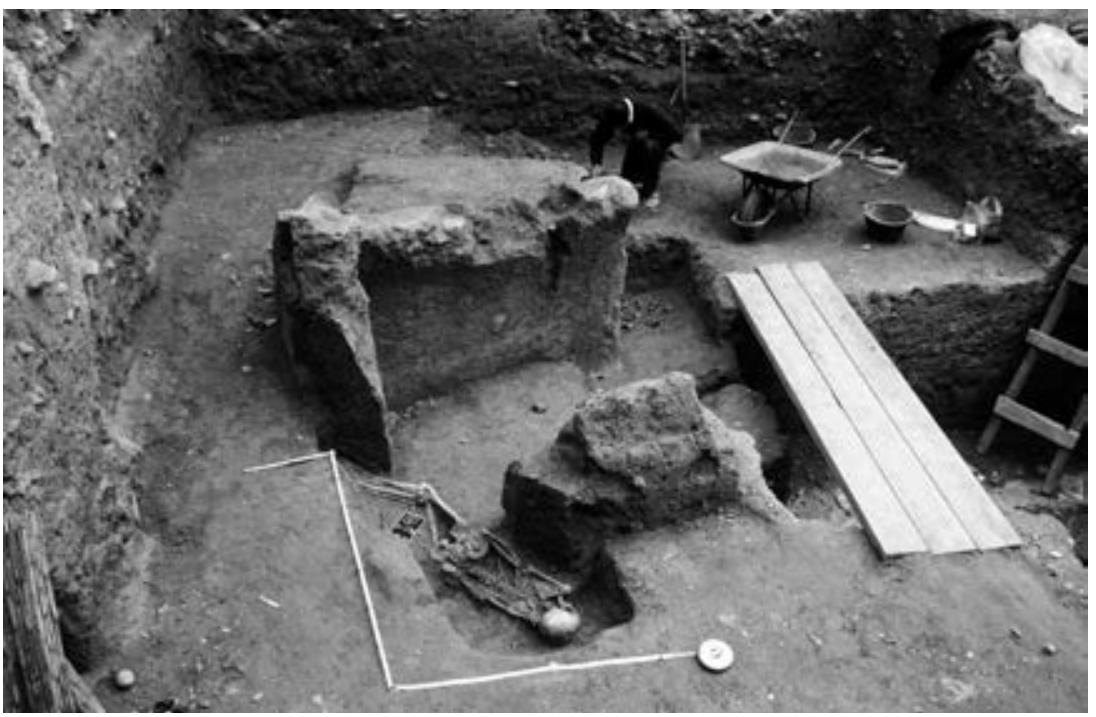

76. En la parte inferior, la Tumba 78 con el individuo musulmán en posición lateral derecha, perforó el ángulo NO del edículo. 


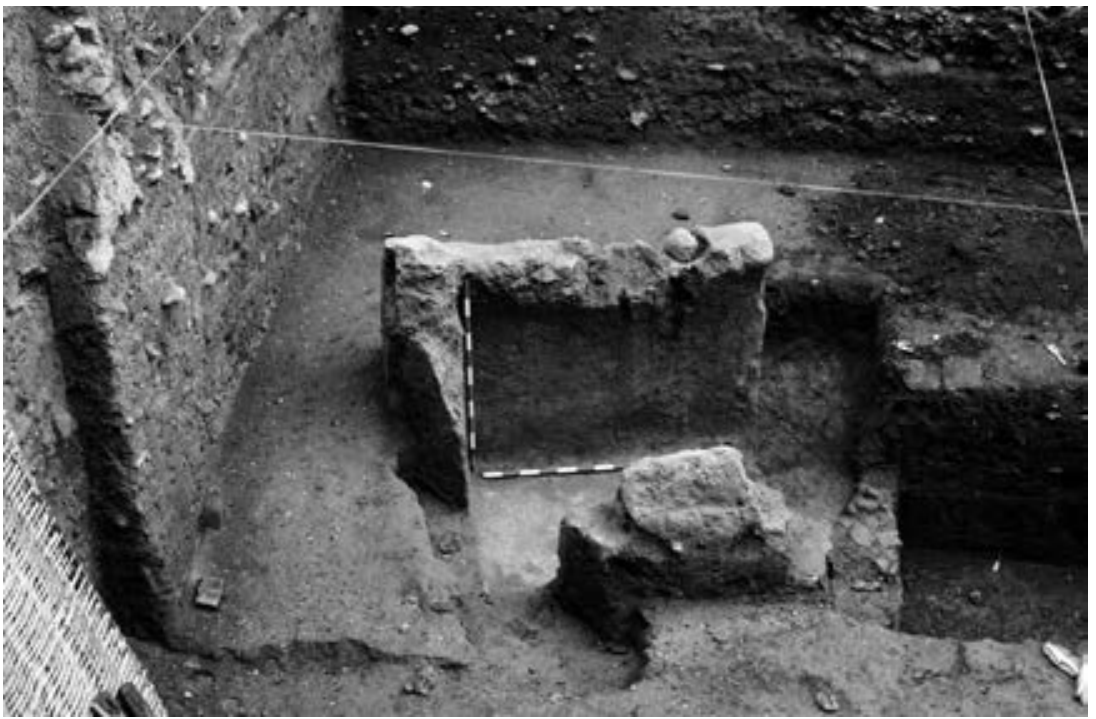

77. El edículo tras el levantamiento del enterramiento islámico.

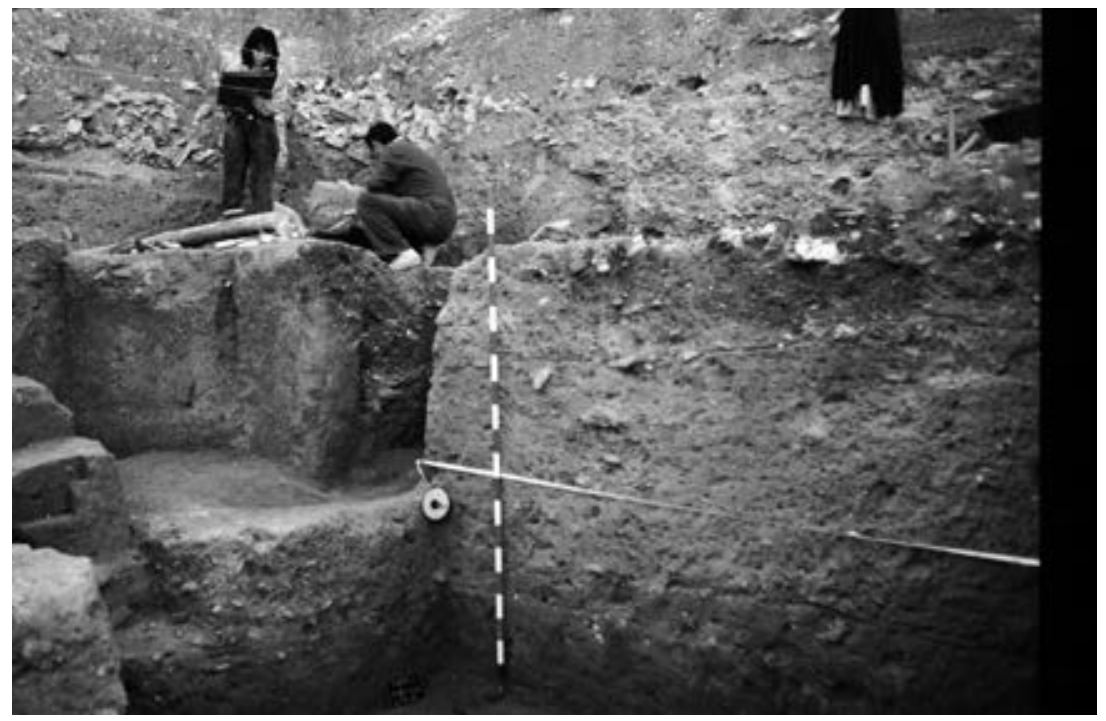

78. En la parte izquierda puede verse el interior del edículo en proceso de excavación. 
Tanto su excelente conservación como el deterioro que presentaba, se debieron a que el pequeño edificio funerario se fue cubriendo lentamente a lo largo de muchos años y a que no sufrió ningún daño intencionado.

$\mathrm{Al}$ respecto, hay que tener en cuenta que es muy raro encontrar la arquitectura e incluso los fundamentos de los monumentos funerarios en las ciudades, ya que han sido aprovechados como material de construcción en época tardía; quizá en este caso su construcción con materiales pobres como el barro y el ladrillo lo salvó de un expolio seguro. Pero más extraño todavía es descubrir restos sustanciales de sus mobiliarios funerarios que puedan permitir su datación (Hatt, 1967, 85). Un dato seguro es que a comienzos de la conquista islámica estaba ya totalmente oculto por tierra, ya que la ausencia del ángulo posterior izquierdo se debía a una fosa excavada en sus muros que por ser de barro no opusieron resistencia. A pesar de que los restos óseos de esta Tumba (n. ${ }^{\circ} 78$ ) se dataron por radiocarbono en $669 \pm 30$, la fecha habría que retrasarla al siglo VIII cuando menos, ya que la posición y orientación del individuo no ofrece dudas sobre el rito funerario musulmán, que tiene que ser posterior a la conquista islámica de Zaragoza. Considerando que una fosa debía tener una profundidad de un metro aproximadamente, esta es la distancia que hay desde la cubierta al fondo de esta inhumación (véase la fig. 76). De la profundidad a la que se excavó la fosa del musulmán se deduce que se enterró en una época muy temprana y que pertenece a la fase más antigua de la Maqbarah Occidental, es decir, al primer nivel de enterramientos de los tres que aquí se conservaban.

Nuestras peticiones para que se respetara este pequeño edificio funerario, el único aparecido en Zaragoza, no fueron bien acogidas por los responsables políticos. En una segunda oportunidad se pidió el rescate de la estructura, que hubiera debido hacerse tras su consolidación y encofrado, pero tampoco se aceptó esta propuesta. Finalmente, se realizó su molde en escayola, tras la consolidación y levantamiento de las zonas en las que se conservaba mejor la pintura. ${ }^{37}$ De mejor suerte ha gozado una tumba romana de

37 Esta labor fue acometida por la restauradora de la Sección Municipal de Arqueología por entonces, Teresa Valtueña, y los miembros también de la Sección, José María Fras e Isidro Martínez (figs. 79 y 80). Las piezas fueron convenientemente numeradas para poder ser utilizadas en la fabricación del positivo exacto del bustum. Se realizó una recreación con motivo de la exposición: Las Huellas del Pasado. Aspectos de Zaragoza a través del Patrimonio Municipal, celebrada en el Museo del Foro (1993). 
inhumación en sarcófago de plomo y cubierta con bóveda de medio cañón hallada a las afueras de Écija, que ha sido consolidada para su traslado al Museo (Fernández, Martín, 2006).

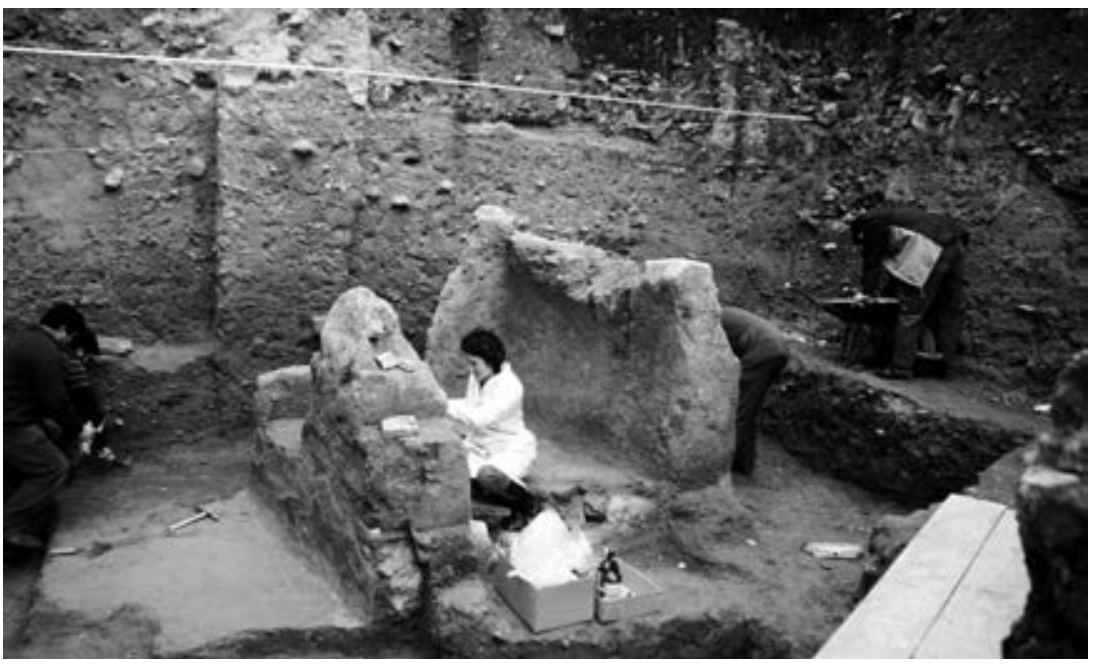

79. Consolidación para la retirada de la pintura.

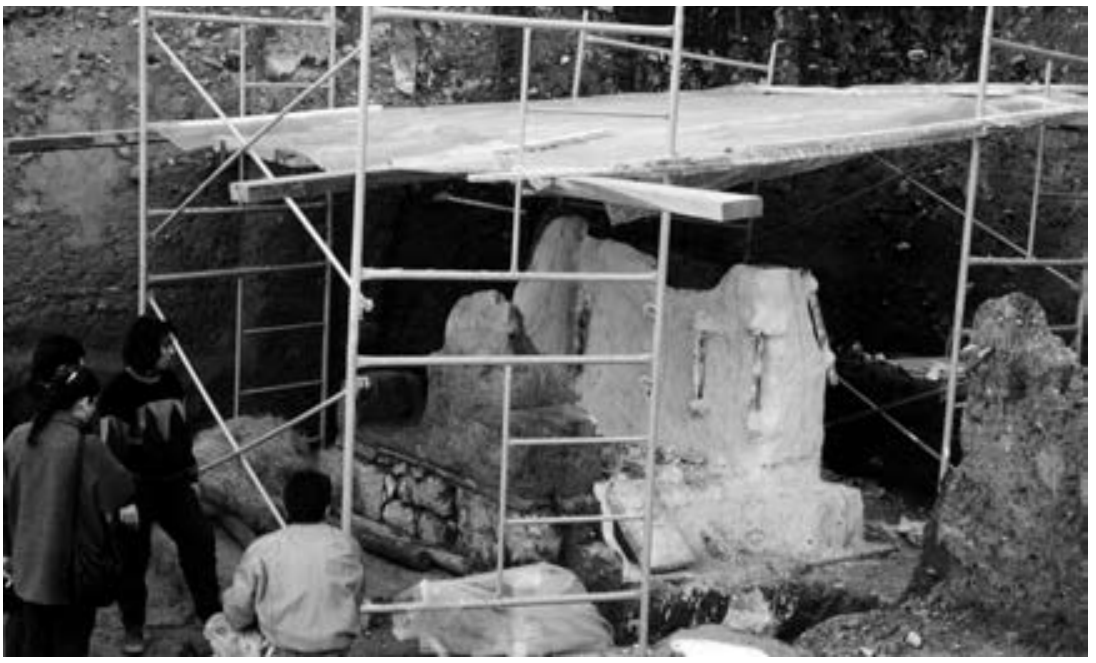

80. Proceso de elaboración del molde en escayola. 
Se trataba de una construcción cuya planta se aproximaba al cuadrado, cubierta de bóveda de medio cañón y con dos salientes en la fachada. En planta alcanzaba una dimensión de 2,30 $\mathrm{m}$ de longitud en los muros laterales, incluyendo los salientes de la fachada principal, cuya dimensión es de $0,45 \mathrm{~m}$ de lado y $0,50 \mathrm{~m}$ de frente. La fachada tiene $2,24 \mathrm{~m}$. Se configura así casi un cuadrado, no en lo que respecta al zócalo de piedra del bustum, cuyos lados laterales son ligeramente más cortos, sino contabilizando la prolongación en saliente de estos en la línea de fachada. En cuanto al alzado, la altura máxima visible de la construcción sería de $2,10 \mathrm{~m}$, mientras que la altura máxima conservada era $1,97 \mathrm{~m}$, y la del zócalo $0,42 \mathrm{~m}$.

En cuanto a la técnica constructiva, la correspondiente al bustum constaba de un zócalo de piedra caliza de sillares bien escuadrados de diferente módulo, en secuencia alterna, de sillares grandes y de otros más pequeños de la misma piedra caliza. Sobre los sillares de este zócalo se depositaron tegulae enteras y fragmentos para asentar sobre ellas el alzado del monumento (la edícula) con otra técnica constructiva: estaba elaborado con adobe y piedra en el interior y enlucido con una gruesa capa de barro. A 0,60 m de la parte superior del zócalo había una hilada de medias tejas planas dispuestas en cuña para comenzar el arranque de la bóveda. La cubierta era de bóveda de medio cañón y su grosor disminuía al ir cerrándose.

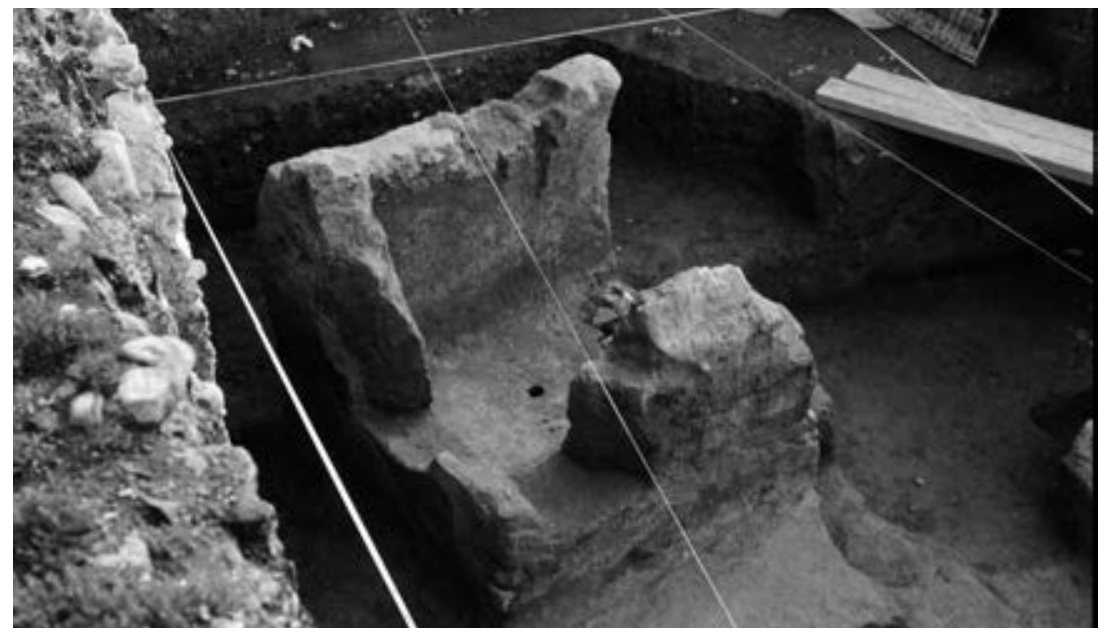

81. Véase la parte inferior del muro occidental enlucido y pintado. 


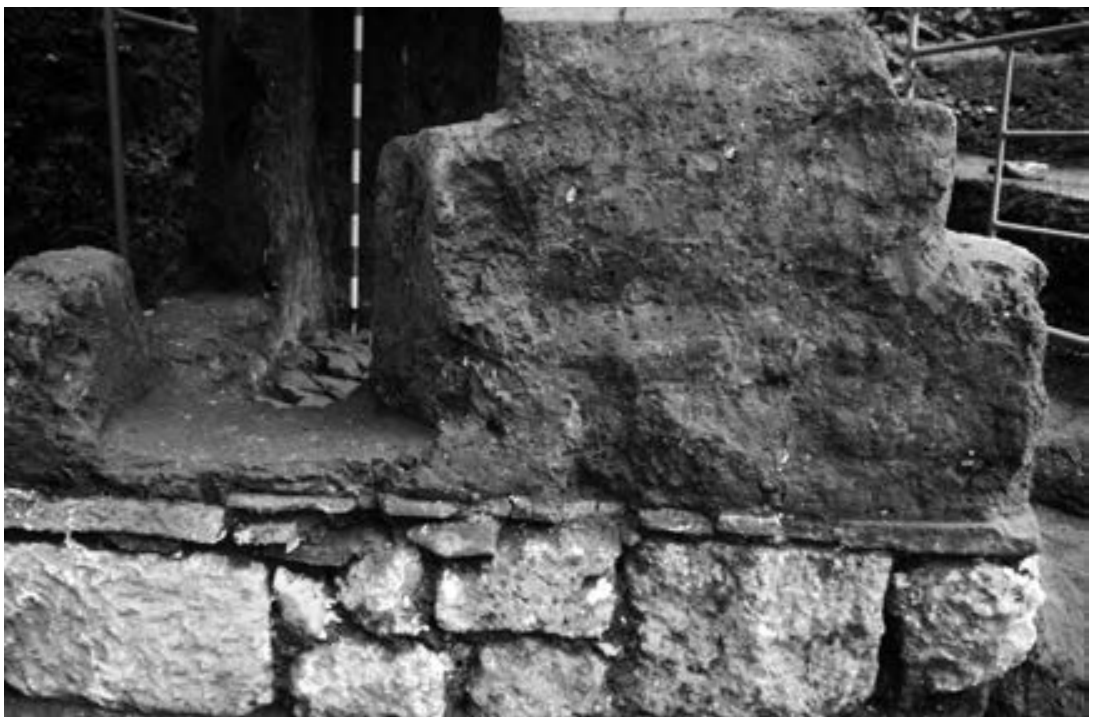

82. Lado occidental del edículo tras el levantamiento del enlucido. Zócalo de sillares. A la izquierda huella de la fosa islámica.

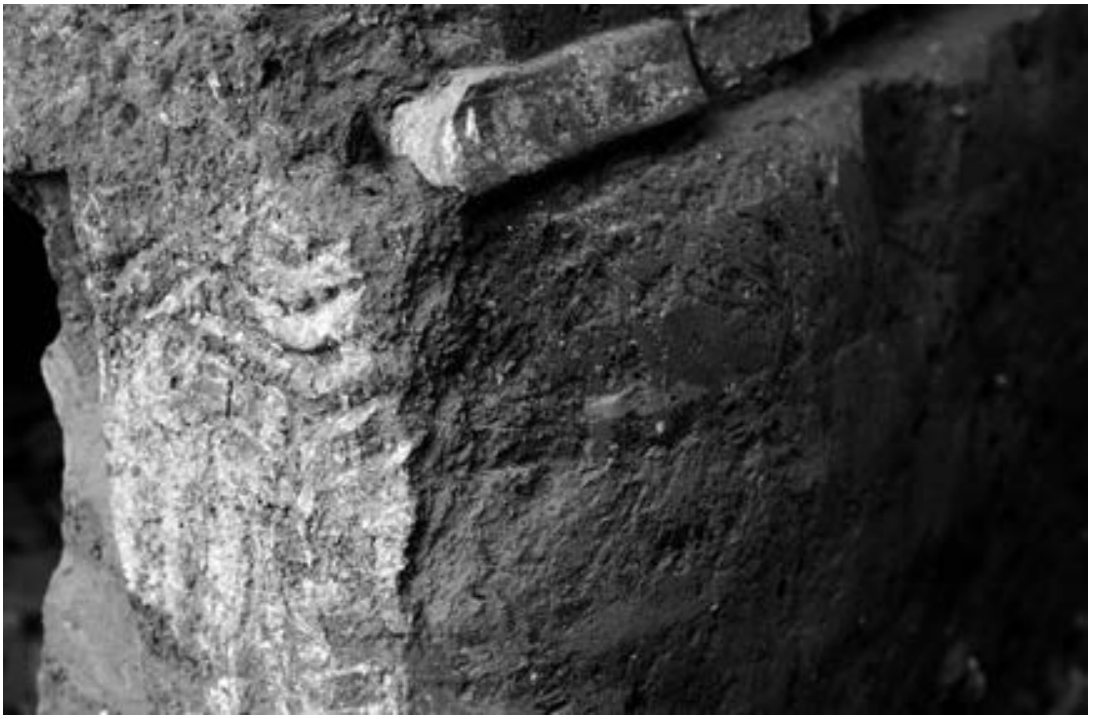

83. Espigado bajo la pintura. Lado oriental. 
El acabado de las paredes, tanto en el interior como en el exterior, constaba de un enlucido cuya aplicación se hizo sobre una capa de $2 \mathrm{~cm}$ de grosor de barro en el que se habían hecho surcos cuando estaba todavía húmedo a fin de que su adhesión fuera mayor, técnica característica del siglo II, se apreció una vez efectuado el molde de escayola, al quedarse adherida a este parte del enlucido. En algunas zonas habría desaparecido por completo.

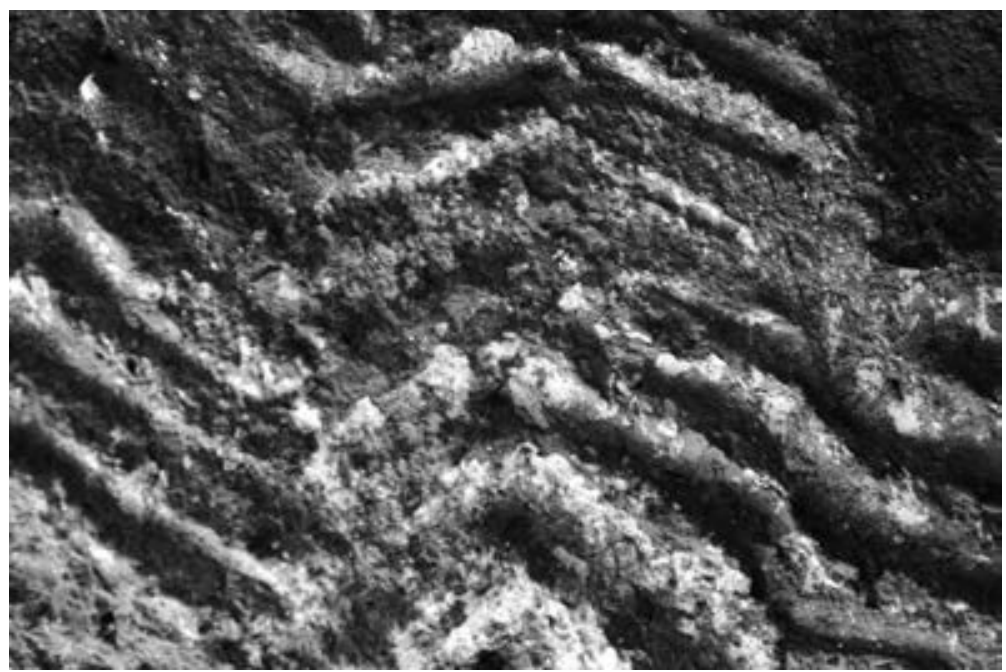

84. Detalle de la preparación.

La mayor parte de la superficie de la zona correspondiente al edículo conservaba pintura de color rojo, como en algunas tumbas siracusanas (Orsi, 1913, 275) o africanas (Baradez, 1967, 11), tanto en el interior como en el exterior, si bien en el exterior el tono estaba mucho más desvaído, seguramente por haber padecido mucho más las inclemencias del aire libre. El interior del edículo, incluso la superficie del suelo, conservaba el color rojo y un salpicado en blanco, negro y amarillo. ${ }^{38}$

38 La decoración pintada en el ámbito funerario era habitual, pero es raro que se haya conservado (Barbet, 2002, 57). Pequeños monumentos «a cassone» de la necrópolis de Isola Sacra con cubierta en bóveda o doble vertiente, conservan todavía restos de pintura (Baldasarre, 2002, 17). 


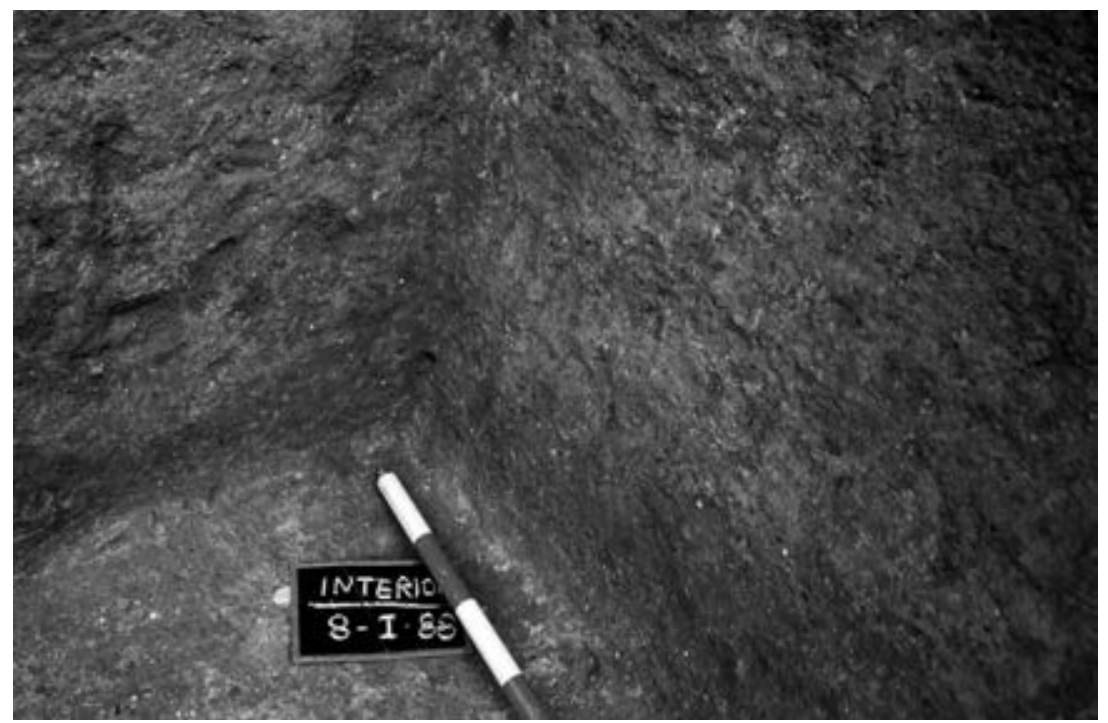

85. Ángulo noreste del interior del edículo.

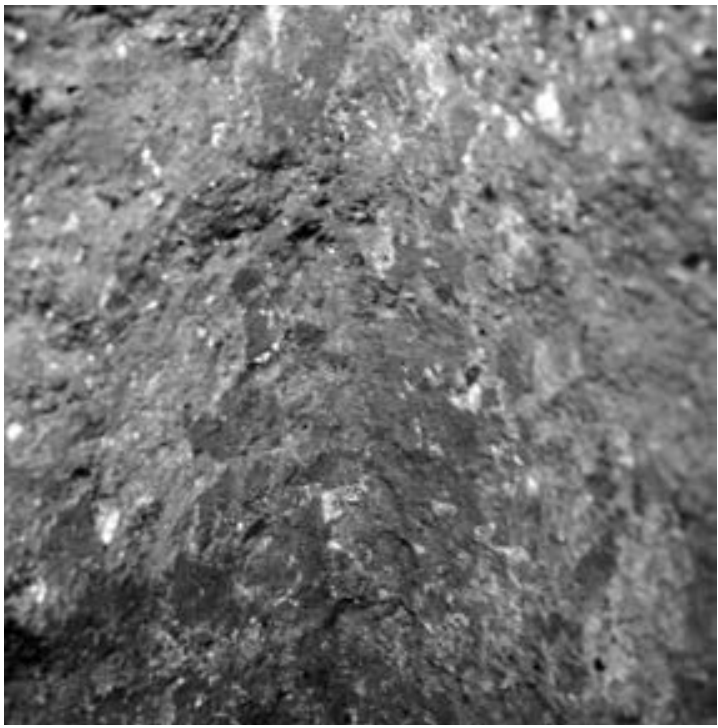

86. Detalle del ángulo noreste. 


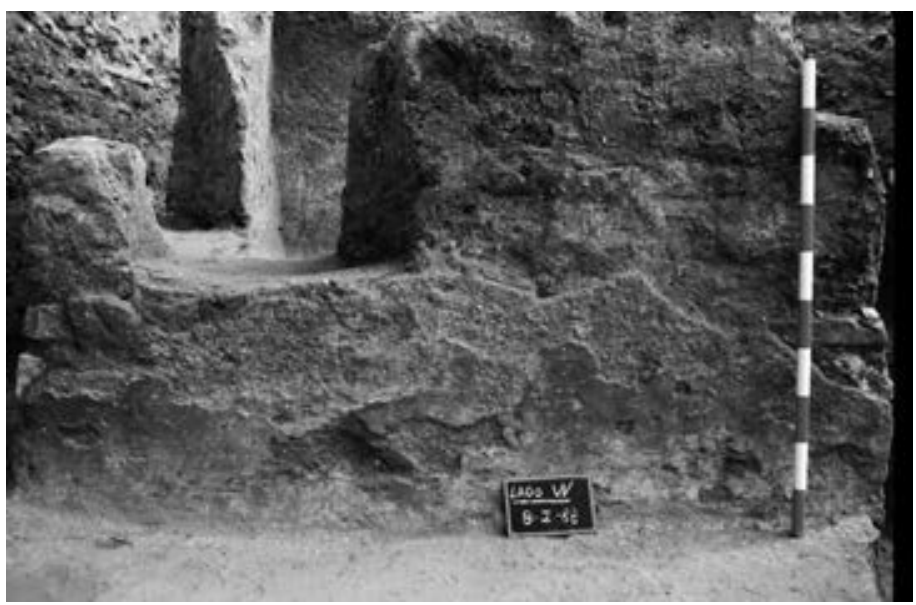

87. Pared occidental con restos de pintura.

La superficie que cubría el bustum era de cal y arena, y perfectamente horizontal; su aspecto era idéntico al de las caras interiores que conformaban el edículo en el interior. En el exterior conservaba del mismo modo el color rojo salpicado de trazos cortos en negro, blanco y amarillo.

Esta superficie interna estaba solo perforada por el agujero circular del canalículo de cerámica que unía el exterior con el interior de la sepultura. La conservación de este suelo, que ejercería de mensa, ya que su escasa altura no permitía el acceso a personas, era buena excepto en la zona de fachada, que estaba rota y permitía ver las capas de tegulae e incluso las piedras del zócalo. Pero, aun así, el bustum se conservaba sellado totalmente y no está de más citar el momento de apertura como uno de los más emocionantes vividos por la firmante y por todos los compañeros que participaron en el proceso a lo largo de un día, hecho que resultó todavía más sorprendente porque se esperaba una inhumación y en cambio lo que aguardaba era una cremación.

Bajo la capa de enlucido y pintura, se documentaron los siguientes elementos de sellado de la tumba:

1. Una primera capa de tegulae, colocadas con los bordes hacia abajo, que conformarían en el momento de su construcción un enlosado horizontal. En el momento de la excavación, el aspecto de este 
suelo de tejas era irregular en lo que respecta a su horizontalidad, debido a la fragmentación de las piezas cerámicas (estas fueron convenientemente numeradas y se realizó el calco para su posible reconstrucción en el futuro). A ras de esta superficie afloraba el conducto cerámico en cuatro o cinco centímetros.

2. Una segunda capa con trozos de ladrillo y pequeños cantos rodados.

3. Una tercera de pequeñas piedras irregulares bastante grandes, como rellenando un hueco.

4. Bajo esto, comenzaban a aparecer ya los vestigios de la pira funeraria, formados por cenizas, carbones, mezclados con otros materiales, especialmente tierras y pequeños huesos calcinados de animales. A medida que se extraía este depósito de color gris, se iba conformando la silueta de un pozo de forma circular. Los bordes y el resto de la superficie estaban endurecidos por efecto de la combustión de la pira que sobre ella se había realizado.

Esta capa de tierras, cenizas y restos orgánicos carbonizados tenía una potencia desigual: oscilaba de nada (bajo el tercer nivel de sellado) hasta $0,40 \mathrm{~m}$, profundidad en la que comenzó a aparecer el enterramiento.

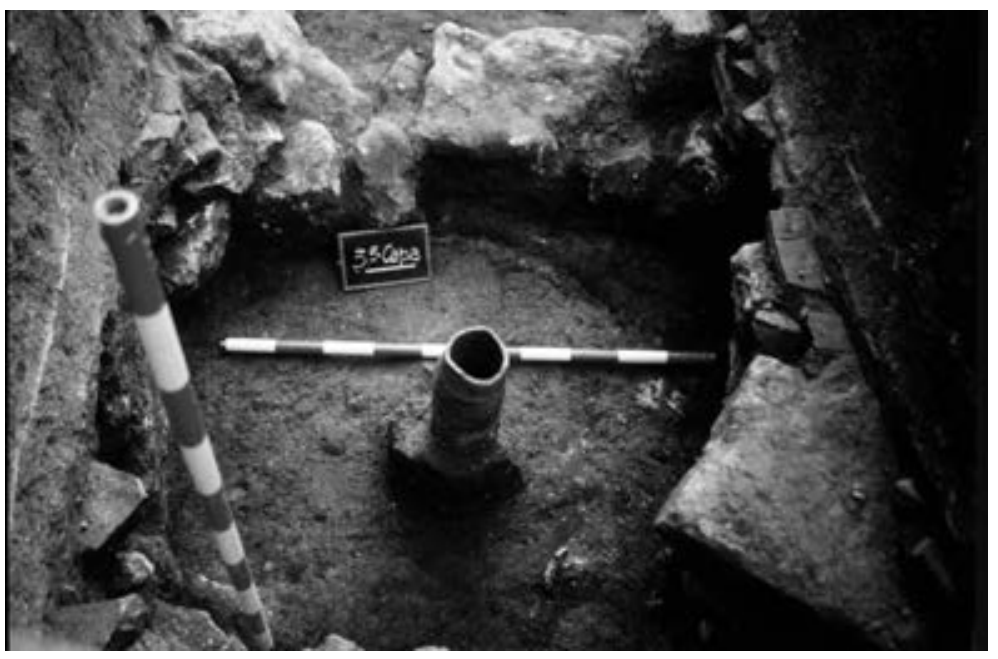

88. Interior del bustum. Pozo cinerario con dispositivo de libaciones. 


\section{El proceso de construcción tras la cremación}

El procedimiento atestiguado durante el proceso de excavación fue el siguiente. Previamente a la construcción del monumento, hay que señalar que la pira funeraria se realizó allí mismo, circunstancia que lo define como bustum. Una vez terminada la incineración, parece que se recogieron, en primer lugar, los restos humanos, depositándolos en la urna dispuesta a tal efecto. A continuación debieron tomarse los restos del banquete fúnebre (fauna y material del ajuar) y reservarlos junto a la urna.

Las piedras que iban a conformar la base del muro estarían ya preparadas e inmediatamente se comenzarían a construir las cuatro paredes. En el zócalo de mampostería se utilizaron piedras con las caras planas hacia el exterior, mientras que en su parte interna estaban sin desbastar, ya que se iban a cubrir.

Se procedió, seguidamente, a la excavación del agujero que debía alojar la urna, revistiéndolo de ladrillos. Una vez colocada y tapada esta, se procedería a enterrarla con las mismas tierras cenicientas del resto de la hoguera y ajuar, y con las diferentes capas sucesivas de suelos que se han descrito más arriba, hincando el canalículo hasta lo más profundo.

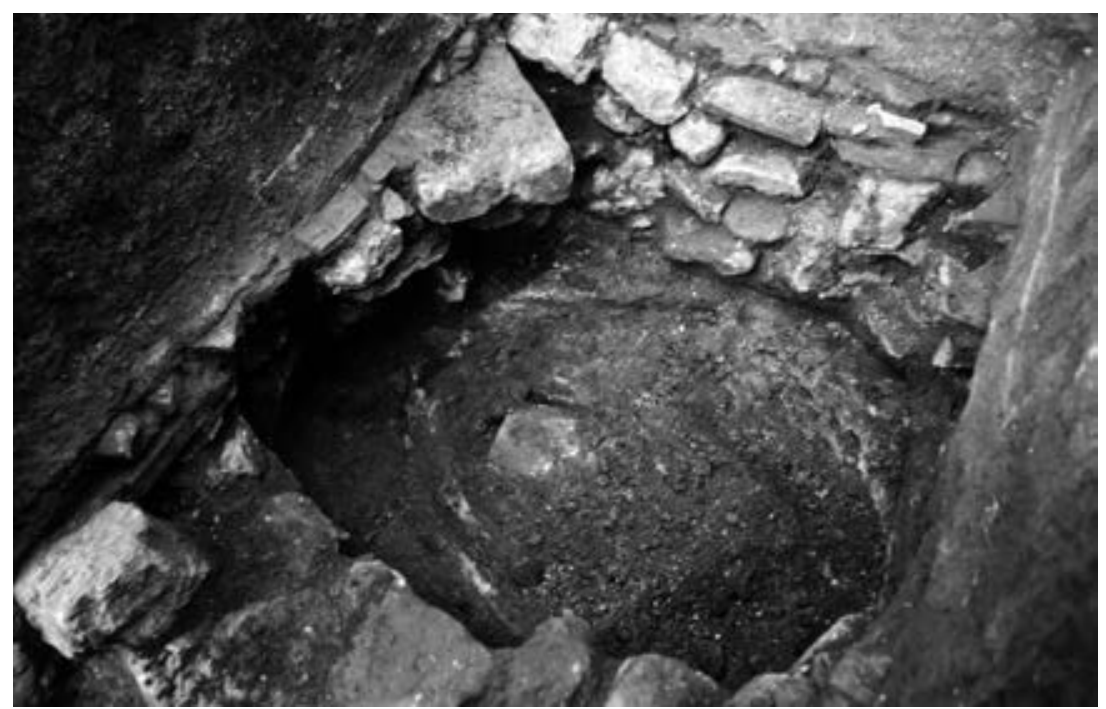

89. Interior del bustum. En el centro aflora el ladrillo plano que servía de tapadera para la urna. 
Tras colocar el último suelo de ladrillo, la construcción debía de tener el aspecto de un pedestal cuadrado, sólido, con la excepción del agujero central.

Tras esta labor se procedería a la colocación de adobes en tres de sus lados, alzando los muros hasta el lugar de arranque del arco, lugar donde se colocaron, en las paredes occidental y oriental, cuñas de ladrillo para base del arco. Una vez concluido este, se revistieron todas las superficies con una gruesa capa de barro; estando este todavía húmedo se le hicieron surcos en espiga continua antes de darle el enlucido. La fase final lógicamente consistió en la pintura, de color rojo y salpicado en blanco, negro y amarillo en el interior del edículo.

A ambos lados de la fachada se construyeron sendos salientes en tapial, cuya función podría haber sido la de servir a la estructura de la fachada, quizá, como se sugiere en la lám. 18, nuestra hipótesis es que estos resaltes sirvieran de apoyo al revestimiento de la fachada de la edícula que podrían haber sujetado un frontón triangular yuxtapuesto a la bóveda. Pero no había testimonios que pudieran confirmarlo. Sin embargo, en absoluto se descarta la única posibilidad dado su estado, es decir, la de fachada en arco.

\section{La posición estratigráfica}

El monumento no poseía ningún tipo de cimentación interna; toda la construcción era aérea.

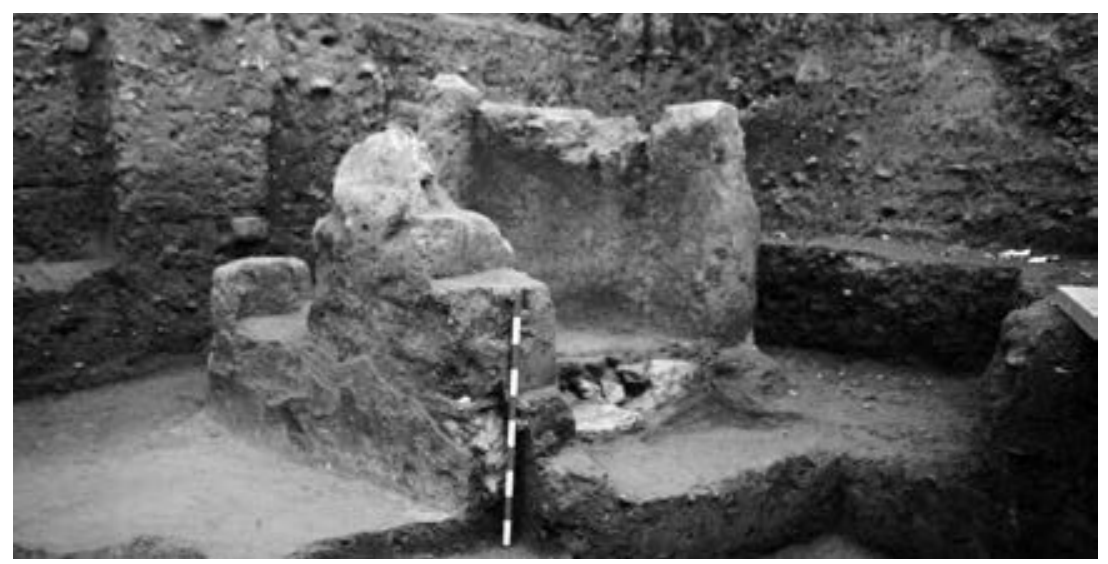

90. El mausoleo visto desde el suroeste. 
La superficie sobre la que se construyó debía estar constituida, como en el resto de los enterramientos romanos del solar de la calle Predicadores, por un nivel de derribo de adobes de los muros de fachada de un edificio que, datando seguramente de época fundacional de la colonia, debió abandonarse a finales del siglo I d. de C. Debió de tratarse de una domus de al menos dos plantas según los cálculos que hemos realizado a partir del grosor de la banqueta del muro de fachada y de la dimensión del alzado de adobes caída y que se conservaba. Es en este nivel de adobes donde se practicaron varias de las fosas de época romana.

\section{La ubicación del monumento}

El valle del Ebro cuenta con edificios funerarios de gran monumentalidad y con estudios recientes de actualización (Cancela, 2006), pero carece de aquellos relativos a necrópolis romanas. Es de destacar el vacío del conocimiento del mundo funerario romano de la zona si se prescinde de los grandes mausoleos.

El monumento estaba situado en una de las vías principales que salían de la ciudad, la que se dirigía a Asturica Augusta, entraba por el puente sobre el Ebro procedente del norte y salía por la Puerta Occidental, yendo paralela al río. En el caso que nos ocupa, la situación del bustum y las tumbas próximas nos sugiere un paisaje funerario variado en la prolongación de la vía decumana.

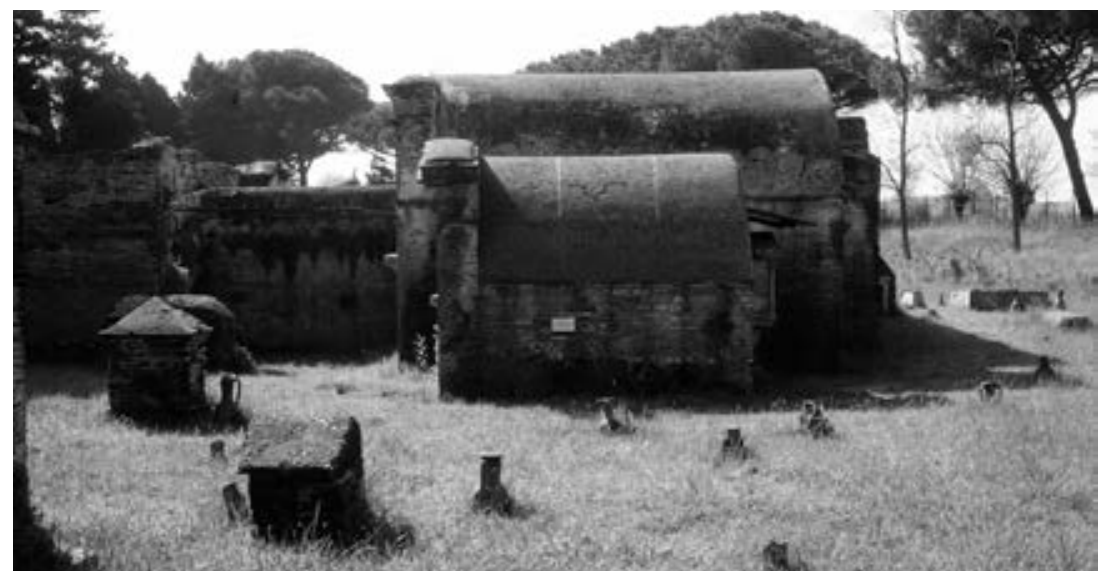

91. Paisaje de pequeños mausoleos y otros enterramientos en las cercanías de un camino funerario. Necrópolis de Isola Sacra (Ostia). 
Habría que tener en cuenta que este sepulchrum, destacado por una pequeña cella, pudo ser un foco de concentración para los demás enterramientos. El fenómeno está suficientemente constatado arqueológicamente: nacimiento de cementerios nucleares que, en ocasiones, se han rodeado de muros privatizando un área determinada. Al respecto, podría considerarse que el grupo de sepulturas de Predicadores tuviera su origen en la existencia de este pequeño monumento funerario, aunque no se detectaran estructuras que se pudieran considerar como cerramientos. Hay ejemplos destacados como el documentado en las necrópolis de Cesarea de Mauritania, donde estas areae, delimitadas por muros, estaban ocupadas igual por inhumaciones que por incineraciones (Leveau, 1987a, 286). Al respecto, otro hecho que nos parece de especial interés para este grupo funerario de Caesaraugusta, es que los mausoleos y las tumbas no forman una línea continua a lo largo de las vías que salen de Cesarea, sino que hay interrupciones importantes, tales como industrias y artesanías de algún modo molestas para los ciudadanos (Leveau, 1987a, 288), fenómeno que también se ha podido observar en esta vía cesaraugustana, como lo son la presencia de alfares (Beltrán, Fatás, 1998, 59) que pudo tener continuidad hasta época islámica; incluso en la zona sur del mismo solar de Predicadores, se excavaron restos de cubetas de mineral y estratos de cenizas que pueden corresponder a un trabajo artesano relacionado con la metalurgia.

\section{Los rasgos tipológicos del monumento: el edículo y el conducto de libaciones}

A la hora de otorgar una clasificación tipológica del monumento, este debe considerarse en el amplio contexto del marco funerario romano. Podría adscribirse al tipo e (Bustumgraber -e) en el que la fosa de cremación es reforzada por piedras, como sucede en la necrópolis de Angera (Van Doorselaer, $1967,106)$ y ello por reunir en sí mismo rasgos de cierta complicación pese a su aparente sencillez, como vamos a ver.

La adscripción tipológica del pequeño edificio funerario corresponde al bustum con aedicula. Se trata de una sepultura abovedada de albañilería, recubierto de una gruesa capa de mortero, enlucido y pintado de rojo. En definitiva, y como es habitual en la terminología funeraria romana, formaría 
parte de lo que se denomina «sepulcro-casa». Sin embargo, pese a su evidencia tipológica, no es fácil conseguir otros ejemplos similares en aspecto y tamaño en el mundo romano, precisamente por la pobreza de los materiales utilizados para su construcción. Así, es frecuente este tipo en piedra, y quizá lo fuera en barro también, pero tal vez no se hayan conservado. Se trata de una construcción modesta, aunque de ejecución esmerada para la que no hemos encontrado paralelo, puede que debido a su desaparición a lo largo del tiempo por motivos muy diversos. Es ilustrativa la destrucción de cámaras de este tipo causada por labores agrícolas en las regiones de Nórico y Panonia (Kremer-Molitor, 2006, 94).

Parece que sus dos características más sobresalientes, la aedicula en bóveda de medio cañón y las perforaciones del enterramiento a través del tubo libatorio, forman parte de una misma corriente funeraria ligada a la costa mediterránea y, en particular, italiana y africana, que se adopta algo después en regiones orientales europeas también, como se verá más adelante.

$\mathrm{Su}$ aspecto externo evoca de alguna manera un tipo de tumba de Isola Sacra, que está caracterizado por la forma de una casa semicilíndrica, cuyos muros están construidos directamente sobre el terreno; está enlucido con una gruesa capa y pintado de color rojo (a veces, con hojas en verde). Es lo que G. Calza (1940, 76-80) denomina tumba a cassone. ${ }^{39}$ Este tipo presenta dimensiones variables y alguno tiene un nicho que sobresale en la fachada coronado por un tímpano triangular para contener la urna o la inscripción funeraria. Estos monumentos funerarios son más modestos en general que los arcosolia (ib., 90-96). El de Zaragoza se aproximaría más al tipo «cassone» que a la monumentalidad de estos. En todos los ejemplos aparece la comunicación para las profussiones liquariae, ritual realizado tras el momento de la muerte que, considerada impura, requería actos de purificación. Se han relacionado con gentes de condición social modesta o baja, es decir, libertos o esclavos (Taglietti, 2001, 155).

En la necrópolis pompeyana de Porta Nocera se encuentra un conjunto funerario que consta de varias tumbas; entre ellas, interesa para nuestro bustum la n. ${ }^{\circ}$. Se trata de un pequeño monumento de bóveda de medio cañón «a fornice» (D’Ambrosio, De Caro, 1983, 1987, lám. 35d, 214-

39 Calza (1940), 76-80. El autor hace referencia aquí también a que sepulturas similares se hallaron en España y África, así como en el Sepolcreto de Ciudad del Vaticano. 
215) que, aunque tiene menores dimensiones, presenta un aspecto muy parecido; se ha datado por el uso de materiales (lava y caliza del Sarno) en época tardorrepublicana o inicios de Augusto (ib., 1987, 215). La fachada está provista de un tímpano en el que se encastró una lastra de mármol blanco portando la inscripción funeraria dedicada a una mujer. Nada puede impedir que la fachada de la edícula de la calle Predicadores portase algo similar. El pequeño frontón podría perfectamente haberse apoyado en los avances laterales de tapial.

Por otra parte, en el cementerio de la Via Triumphalis se encuentra un pequeño monumento, muy deteriorado, de planta casi cuadrada, que tipológicamente responde al tipo de recinto abierto con nichos para urnas (Steinby, 1987, 91, Tumba 10a, lám. 10a). Estaba enlucido y pintado de rojo, al igual que otro de proporciones más modestas con hornacina para una única urna (Steinby, 1987, 91, recinto 4a, lám. 11b; 12a).

Ahora bien, si los ejemplos que acabamos de citar corresponden a Italia y a comienzos del Imperio, a partir del siglo II la referencia obligada la constituyen los monumentos funerarios individuales africanos. Entre ellos el tipo más extendido es el arcón, tumba semicilíndrica que en Cesarea y Tipasa son obras de albañilería sobre las que se coloca el monumento funerario, bien directamente sobre la tumba o con interposición de cerámicas y tejas. Leveau considera esta característica una tradición africana $(1987 a, 285)$; en Cesarea la tumba cubierta por tejas va dejando paulatinamente de ser protegida por un monumento funerario a partir del siglo III.

Las numerosas excavaciones realizadas en los últimos decenios del siglo XX han proporcionado importantes novedades también en Hispania. La decena de edículos funerarios de la necrópolis emeritense, de planta cuadrangular más o menos, que afloraban a uno y otro lado de la calzada antigua a Corduba coincidente en este tramo con la carretera moderna, constituyó el primer caso aparecido en España de «una necrópolis romana de carácter monumental al modo de la Via Appia, es decir, a ambos lados de una de las vías de salida de la ciudad emeritense» (García y Bellido, 1962, 3-5). Pero, según los planos que aparecen en esta publicación, son todos de mayores dimensiones que el de Predicadores y, además, parece que se trataba de construcciones sin techado. 
Monumentos funerarios de reciente excavación son los de la calle San Vicente (Liria, Valencia), ubicados en la vía funeraria que conducía a Valentia y que han sido datados a finales del siglo I y la primera mitad del siglo II a. de C. (Martínez Cabrera et al., 1989; Rivas et al., 1990). Sin embargo, su carácter monumental no es comparable con el de Caesaraugusta, mucho más modesto este en su fábrica y proporciones.

Es de destacar que, a pesar de la abundante literatura existente sobre el aspecto formal de los monumentos funerarios de época romana, no ha sido fácil clasificar el hallado en la calle Predicadores. No acaba de encajar en un tipo determinado, quizá porque este tipo de construcciones es poco estereotipado: su carácter particular permite la introducción de innovaciones o cambios por parte de arquitectos, artesanos o por los mismos propietarios (Sanmartí, 1984, 88).

El de Zaragoza, de una gran simplicidad como se ha visto, encajaría en lo que investigadores italianos (Mansuelli, 1963; Torelli, 1968) han venido denominando aedicula, a pesar de que este término, cuyo significado es lo mismo capilla que casita, con independencia de su fachada, su cubierta o que está abierta o cerrada, resulta ambiguo debido a su generalidad. Así, por aedicula funeraria podría entenderse lo mismo un sepulcro-templo o un sepulcro-casa (Bonneville, 1981), cuando en realidad deberíamos decantarnos por una cella funeraria edificada para una función ritual determinada.

Desde un punto de vista objetivo, el análisis de la nomenclatura y su definición respecto a las tumbas semicilíndricas, cupae y algunas de las que podrían o vienen definiéndose como casas-sepulturas, proporciona al lector una visión rica en conjunto - si se admite que todas ellas parten de una idea común, a pesar de diferencias sustanciales como puede ser el tamaño, el rito o la presencia o ausencia de decoración-; pero resulta bastante complicada por la falta de precisión en las descripciones, por el subjetivismo vertido a veces y, sobre todo, por la frecuente ausencia de material gráfico en las publicaciones, hecho que consideramos imprescindible para la clasificación correcta de estos tipos. A ello se añade el hecho de que las opiniones vertidas por los especialistas en la bibliografía existente es, a veces, controvertida, en especial la italiana, que provoca cierta ambigüedad en lo que respecta al término aedicula sobre podium. No obstante, la idea más generalizada es la de emparentar los arcones, tumbas semicilíndricas, cupae, en cierta manera, con las 
sepulturas de tipo oikomorfos de techumbre en bóveda (Berciu, Wolski, 1970, 928-932; Bonneville 1981, 15)..$^{40}$ Sin embargo, son las tumbas con cubierta a doble vertiente y las casas-sepultura con cubierta abovedada de Asia Menor y de África los ejemplos más fidedignos a la reproducción de viviendas, de sus respectivas zonas. ${ }^{41}$

A la hora de explicar el uso de la bóveda en las sepulturas hay que acudir a su empleo en la arquitectura doméstica más sencilla, y no cabe duda de que su mayor difusión al respecto se alcanza en Egipto, donde quizá se impuso este tipo de cubierta en época helenística a causa de la escasez de madera. Fue característico de casas de Alejandría y arrancó de la arquitectura tradicional egipcia (Nowicka, 1969, 163). Sobre el territorio de Asia Menor y de África, el prototipo de casas de habitación de techumbre abovedada era conocido por todas las clases sociales, y en época helenística se manifiesta una generalización de su empleo, con independencia del material; y no es extraño que este fenómeno alcance también a la construcción de los sepulcros. ${ }^{42}$

Gran cantidad de monumentos funerarios, entre los que se encuentra el de Zaragoza, que se han venido denominando por su aspecto físico de diferentes formas según la nacionalidad del investigador que haya acometido su estudio — «á caisson», «a fornice», «tombe a cassone», cupa- tienen un común denominador: la bóveda de medio cañón. Existe un tipo unitario de tumbas con bóveda y ello aunque varíe la forma de las bóvedas (de estricto

40 No se va a tratar aquí del tipo de sepultura cuya construcción termina en techumbre a doble vertiente, ya que, si bien la idea fundamental sería la misma, la de morada perpetua para el difunto, este detalle constructivo facilita su exclusión de nuestro tratamiento.

41 Berciu, Wolski (1970), 962. Cumont (1949), 24 indicó que la tradición de construir tumbas que imitan casas es una idea común en la Antigüedad, y ya R. Pagenstecher en Nekropolis. Untersuchungen über Gestalt und Entwicklung der alexandrischen Grabaulagen und ibren Malerein, Leipzig, 1919 (citado por Berciu y Wolski, 928, nota 3) subrayó las analogías entre tumbas y casas de Priene y Delos y casas griegas de Egipto.

Las investigaciones de necrópolis helenísticas de Egipto han servido para reconstruir tipos de casas urbanas en Alejandría: cementerio de Mustafá Pachá (Adriani, 1936, 96). Berciu y Wolski (1970), 929 sugieren la hipótesis de que los sarcófagos abovedados de Dacia y otras provincias pudieran considerarse también como modelos o copias de casas de habitación, tal y como se ha demostrado en las tumbas licias, que son la copia de un tipo de habitación de madera de esta región.

42 Berciu, Woslki (1970), 932. Los autores rumanos opinan que la presencia de techos abovedados, más que deberse a condiciones climáticas o económicas - tal y como han tratado de explicar algunos autores-, depende de los recursos y posibilidades del país. 
medio cañón, o rebajada, e incluso algo ojival) (Berciu, Wolski, 1970, 959). Ahora bien, tratar de elucidar las variaciones tipológicas de todos ellos es asunto complicado, pues se trata de interpretaciones a veces meramente subjetivas y sin posibilidad de matización, amén de que su importancia puede disminuir por ser diferencias de carácter estrictamente local. ${ }^{43}$

\section{Topografía de las tumbas con bóveda}

Exceptuando los grandes monumentos, en la Península Ibérica hay una predilección por las tumbas semicilíndricas en época romana. Con base de una sola altura o escalonada, con fábrica hueca en ladrillo o macizas, guardaban las cenizas o los restos del individuo, y además tenían cubierta de tejas o ladrillos, al igual que sucede en África. Incluso se ha atribuido a las tumbas de albañilería de tipo cupa una subvariante local limitada a España, como una simplificación del tipo africano o bien de una combinación de elementos heterogéneos. ${ }^{44}$ Suelen emparentarse con las africanas, hecho que habría dejado sentado Juliá para el caso de las de Tarragona basándose en la epigrafía existente sobre estos soportes semicilíndricos (Juliá, 1965, 52-54)..$^{45}$ Por otro lado, la presencia de este tipo se circunscribe preferentemente a la costa tarraconense (Tarragona, Barcelona), ${ }^{46}$ a la Bética (Belo, Carmona y recien-

43 Los autores señalados plantean que estas diferencias (forma de las bóvedas, materiales y técnicas constructivas) se hayan derivado de la distancia de la fuente (Berciu, Wolsky, 1970, 959). De este modo, las cubas semicilíndricas que predominan en zonas africanas, españolas e italianas, son reemplazadas al otro lado del Imperio por otros tipos, y cuanto mayor es la distancia de la fuente original más divergente es la solución adoptada para tratar temas comunes.

44 El más simple serían las fosas profundas con cubierta de revestimiento de lajas, y el segundo el resultado de una combinación de elementos heterogéneos, es decir, de cámaras o criptas subterráneas, combinadas con el principio de tumbas de bóveda (Berciu, Wolski, 1970, 959).

45 No vamos a profundizar en el tema porque, si bien consideramos a las cupae como una variante de los sepulcros en bóveda que con frecuencia cuentan con tubo de libaciones, tienen escasas concomitancias con el alzado del bustum de Zaragoza. El trabajo básico para su estudio sigue siendo el de D. Juliá (1965), 29-72. Para las cupae de Barcelona, vid. J. N. Bonneville (1981), 5-38 y, recientemente, D. Vaquerizo (2006). De gran interés es la revisión de J. López Vilar (1999-2000).

46 Formalmente debe citarse un monumento cercano a Zaragoza, el de Miralpeix (Caspe, Zaragoza), cubierto con bóveda de medio cañón y podio, y datado por material cerámico de un yacimiento próximo en el siglo II o principios del III y en la forma de los capiteles corintios (J. Lostal, 1979, 247; J. Sanmartí, 1984, 112). Se desconocen datos sobre ritual funerario. 
temente Sevilla [Ordóñez, García Dils, 2004, 166]) y a la Lusitania (Fabrè, 1973; Vaquerizo, 2006, 342-344). ${ }^{47}$

La vinculación con la zona africana para este tipo de monumento ha sido defendida, además de por Juliá, por arqueólogos hispanos como Bendala, que no menosprecia por ello las influencias orientales en el occidente del Imperio (1976, 151), Blázquez (1976, 60-61; 1978, 205-206) o Vaquerizo (2006, 318-319). De ser así, sería un hecho similar al del fenómeno de los sepulcros turriformes, que tuvieron origen en Siria y en Egipto (Cid, 1949, 93-95).

En cierto modo, partidarios de una corriente greco-oriental son Wolski, Berciu y Bonneville. Los autores rumanos opinan que imitan el tipo de gran sarcófago a escala reducida, que cubren las laderas de ciudades licias y se cuentan por miles (Berciu, Wolski, 1970, 953). Sin embargo, no acaban por decantarse por la procedencia oriental, aunque como Juliá, la encuentran una hipótesis seductora, imposible de verificar. Por otro lado, Bonneville parece también partidario de una corriente greco-oriental a partir de las grandes tumbas en bóveda de Asia Menor, que iría unida al uso de sarcófagos para el grupo de cupae catalanas, en particular las de Barcelona, si bien parece inclinarse finalmente por una ecléctica, defendiendo la intervención de la corriente africana para la época de Trajano y Adriano (1981, 37-38).

En La Madrague de Saint-Cyr-sur-Mer, antigua Tauroentum, se conserva un pequeño monumento funerario, al que se hará referencia más adelante al tratar de los tubos de libaciones, ${ }^{48}$ y al que su investigador considera una casa-sepultura, emparentándolo con la cupa tarraconense al menos en su parte aérea y cuya cronología no es anterior al siglo III (Benoit, 1956, 218).

Si como parece, el sepulcro abovedado es un prototipo del mundo oriental de época helenística, no es extraño el hecho de que los que aparecen en la necrópolis ostiense de Isola Sacra, sirvan a una población heterogénea en una ciudad en la que el elemento oriental era preponderante

47 A propósito de la cupa lusitana de P. Aelius Ianuarius, Fabre se decanta por un origen ostiense (aunque a través de corrientes orientales, mientras que de Isola Sacra arrancarían los prototipos de cupae monolíticos, que serían reducciones en tamaño de los grandes monumentos de bóveda cilíndrica tan apreciados por las familias italianas y serían una adaptación a las posibilidades económicas más reducidas de un grupo social provincial de esclavos y libertos (Fabrè, 1973, 114, nota 4, y 124).

48 Véase p. 117. 
- y al que se añaden las fuertes tendencias orientalizantes del siglo II a partir del reinado de Trajano-. El grupo de Isola Sacra, al que Calza (1940, 76-80) denominara tombe a cassone, se caracteriza por una especie de cofre construido por técnica de albañilería con la cubierta abovedada. El tubo de libaciones - generalmente formado por cuellos de ánforas superpuestos- está presente en todas las tumbas. Se trata de sepulcros para contener las cenizas que se custodian en la urna, y no se trata de busta, sino que el proceso crematorio había tenido lugar en ustrina con anterioridad. Algunas de estas tumbas presentan en uno de sus lados forma de templo. Otro grupo importante de este tipo en la Península Itálica es el de la necrópolis del Vaticano en Roma. Ambos conjuntos se datan durante los siglos II y III.

Un grupo de tumbas abovedadas interesante es el del valle del Tanagro en Lucania, que Bonneville cree posterior a la mitad del siglo II y se inclina a datarlos en la tercera centuria según los datos que aporta la epigrafía (1981, 20-21).

El estudio de J. López Vilar (1999-2000) contiene un estado de la cuestión sobre todas estas estructuras abovedadas, sean cupae o no, en el que se establece una sistematización en cuatro tipos afines entre ellos y cuyo nexo común es su aspecto semicilíndrico (84, lám. 15). De estos tipos interesa especialmente el n. ${ }^{\circ}$ 4, correspondiente a los dos mausoleos de la necrópolis de La Barquera en Perafort (Tarragona), que tienen en común con el mausoleo de Zaragoza la bóveda, el tamaño aproximado y el enlucido; en cambio, presentan diferencias sustanciales en el rito utilizado (inhumación) y la cronología tardía (siglo IV o V), aunque López Vilar los emparenta con el n. ${ }^{\circ} 114$ de la necrópolis oriental de Sitifis (Argelia) que se data a comienzos del siglo III.

En la zona del norte de África los sepulcros en bóveda fueron descubiertos por primera vez a mediados del siglo XIX por Delamare ${ }^{49}$ en Argelia, y tienen también una importante representación en ciudades de la costa tunecina. En Hadrumentum se trata de arcones semicilíndricos (Berciu, Wolski, 1970, 945, n. 1); los de Thaenae sirvieron para establecer la clasificación tipológica de las tumbas en bóveda africanas que elaboraron a principios del

49 H. E. Delamare (1850) (citado por Berciu, Wolski, 1970, 944, nota 2). 
siglo Xx Barrier y Benson (Berciu, Wolski, 1970, 926), y en Tipasa se excavó un grupo excepcional (Baradez, 1967, 11). Sin duda por ello, autores como Baradez o Gsell se han mostrado partidarios de un origen púnico para este tipo de enterramientos de época imperial (Gsell, 1901; Baradez, 1967). No obstante, no debe olvidarse que las estructuras monolíticas semicilíndricas se encuentran muy extendidas por otras amplias zonas del África romana, además del grupo tunecino.

En otro sentido Mansuelli $(1963,199-200)$ observa que la arquitectura funeraria, como expresión de la convivencia del imperium populi Romani, participa también del eclecticismo formal y del sincretismo conceptual del mundo romano, que se ha demostrado que cada monumento constituye un problema por sí mismo, y da por sentado que la temática monumental funeraria deriva más o menos directamente de Oriente. Apunta también a la larga tradición helenística, aunque califica ahistórico tanto el hecho de plantear «orígenes» como la defensa de la paternidad de una u otra región para algunos tipos monumentales.

Berciu y Wolski $(1970,945)$ y anteriormente Juliá $(1965,46)$ se decantaron por influencias helenísticas. Serían elementos orientales los que transmitieron el tipo de sepultura, que hace su aparición a partir del siglo I constituyendo el «último eslabón de la cadena»-desde la práctica de tubos de libaciones en casos más antiguos de Grecia o Egipto- en Asia Menor (Licia y Frigia).

De forma intencionada se ha reservado para el comentario final de la dispersión geográfica de las tumbas de bóveda unas regiones que parece muy interesante considerar en esta cuestión y en la época en la que se erigió el pequeño monumento. Nos vamos a referir a Mesia, Dacia y Panonia.

$\mathrm{Al}$ respecto, Wolsky y Berciu acometieron el primer estado de la cuestión en profundidad basándose en un hallazgo funerario de Apulum, el mayor centro urbano de Dacia, tras ser vencidos los dacios por Trajano (año 106), sede de la XIII Legión Gémina. El tema versaba sobre lo que denominaron sarcófagos en albañilería de cubierta abovedada del Imperio romano, que continúa siendo el trabajo básico para cualquier tratamiento de las sepulturas de bóveda del Imperio.

El pequeño monumento de la calle Predicadores presenta concomitancias con un monumento funerario de Dacia, que se hacen patentes tanto en 
el proceso constructivo como en su resultado final: es abovedado, está enlucido de rojo y cuenta con dispositivo de libaciones. Las similitudes que queremos destacar con el de Zaragoza se hacen evidentes en la descripción de Berciu y Wolski $(1970,957)$. Se trata de un monumento funerario hallado en Alba Iulia (Apulum) en la Dacia Superior y datado como el de Zaragoza a finales del II o comienzos del III, que está construido en la misma fosa donde tuvo lugar la incineración, como los ejemplares de Tipasa y Belo, pero tiene el arco levemente apuntado como algunos de Tarragona. Está enlucido de rojo como algunos de África, Ostia y de la Península Ibérica, y cuenta con orificio para las libaciones. El de Apulum parece ser una construcción de tipo grecoriental (lám. XL, fig. 1).

En la antigua Drobetae, ciudad junto al famoso puente de Trajano, en la orilla izquierda del Danubio (Dacia Inferior, Rumanía), hay un grupo de sarcófagos en bóveda, datados en la segunda mitad del siglo III, en obra de ladrillo revestido de mortero y con enlucido basto. Sin embargo, no tienen orificios para las libaciones funerarias y se trata también de inhumaciones, lo mismo que sucede con el grupo de Panonia (Berciu, Wolski, 1970, 957). Berciu y Wolsky (1970, 964-965) ponen en relación los descubrimientos de Panonia, donde había una poderosa colonia hebraica con sarcófagos abovedados, con la necrópolis del Monte de los Olivos, datada entre 135 y finales del siglo IV y también con el grupo de cupae de piedra de Tarragona.

En Mesia Inferior hay otro ejemplar de sarcófago abovedado datado en la segunda mitad del siglo II, que por su aspecto formal nos recuerda también al de Zaragoza: el de la antigua Pantalia (actual Kyustendil, Bulgaria), que fue importante centro comercial, administrativo y cultural en los dos últimos siglos de la era. Después, al ser creada la provincia Dacia Inferior, se consideraba la tercera en importancia de esta, a orillas de una importante calzada y donde se erigió una gran fortaleza, guarnición donde se alojó una cohorte de auxiliares romanos para defender la ciudad. A partir de la excavación de las necrópolis se ha podido averiguar que la población mantuvo las costumbres funerarias tracias con sus enterramientos de altos oficiales con sus armas y carros. El mausoleo que nos interesa está fabricado en ladrillo y mortero y, a cierta altura, presenta tres hiladas de ladrillos, sobrepasando en algunos centímetros la línea de la pared, que marcan el nacimiento de la bóveda. Consta de bóveda de medio cañón y de 
cámara subterránea; está enlucido en el exterior, e I. Ivanov no precisa en su estudio ni el color ni si contaba con tubo libatorio, aunque sí que se trata de una incineración. ${ }^{50}$

\section{Las tumbas provistas de tubos de libaciones}

La presencia de dispositivos para las libaciones, que los autores galos han venido denominando tombes à cheminées, corresponde a un fenómeno muy ligado a la costa mediterránea y, en particular, a la africana, durante los siglos II y III d. de C.

Este elemento salió a la luz de la investigación por primera vez con la publicación de las necrópolis de Cartago y de Pompeya. A. Delattre (1888) fue el primer autor que se interesó por el tema al publicar los resultados de las excavaciones de las dos necrópolis romanas de Cartago, señalando que el canalículo servía para verter líquido a su través y para introducir las cenizas en las tumbas. El primer objetivo es evidente, y, en cuanto al segundo, venía originado por el hallazgo de algunos altares fúnebres con urnas vacías mientras que los tubos estaban llenos de huesos calcinados y de ceniza.

En el mismo año se excavaron tumbas con dispositivos de libaciones en la vía Nucerina en Pompeya (Mau, 1888), en este caso se trataba de un edificio rectangular con urnas cuyas tapaderas estaban perforadas por tubos de cerámica. También en Pompeya, en la necrópolis de la Porta di Nola, se pudo comprobar la existencia de un tubo para la libación directa al interior de la urna o, en otros casos, a la tierra junto a ella (Kockel, 1987), como ocurre con el del bustum de Zaragoza.

Orsi excavó en Siracusa cámaras hipogeos, construidas entre el siglo II a. de C. y el I d. de C., pertenecientes a familias o a soldados de origen humilde (Orsi, 1913, 257-280) que contaban con tubos de «aireación». El arqueólogo italiano indica que la función de estos tubos era no solo ventilar el sepulcro y protegerlo de la humedad, sino también por razones de tipo ani-

50 I. Ivanov, «Otcet za razkopkit pri kadin-most (Kioustendil)», Izvestia ha bylgarskoto Archeologhistchesko Droujestvo I, 1910, 173-177, figs. 17-19, según referencia de Berciu y Wolsky, 1970, 938, nota 2, fotografía en la figura 18. 
místico, es decir, para la posibilidad de un contacto entre los vivos y los muertos. Oeconomus $(1921,63)$ distinguía entre las libaciones en general y los instrumentos dedicados a estas ceremonias. En el mismo año, Moretti (1921, 195) hizo también alusión a la rareza del uso del tubo de libaciones entre la cella de la tumba y la urna de las cenizas en tumbas de la antigua Falerio. Este autor relacionó la perforación de arriba abajo para la introducción de las libationes liquariae hasta las cenizas sepultadas con algunos sepulcros descubiertos en Cartago por Delattre, a los que se ha hecho ya referencia. Los conductos de comunicación eran tubos de cerámica, entre la urna custodiada dentro del ara funeraria y la superficie externa del plano superior. ${ }^{51}$ Entre seis tumbas en la Vía Nucerina en Pompeya ${ }^{52}$ una de ellas es mencionada por Moretti como edícula funeraria con tubo, cuya boca podría cerrarse, que guardaba el área donde estaba enterrada la urna con los restos de la cremación del cadáver.

Poco más tarde, en 1929, Wheeler citaba dos hallazgos de tumbas con dispositivo de este tipo en Gran Bretaña. Una de ellas, en Caerleon, estaba provista de un tubo de plomo de una pulgada y media de diámetro y de tres pies y tres pulgadas de longitud, y se trataba de una incineración de época de Adriano $(1929,4)$. La otra que presentaba también un tubo de plomo era un sarcófago de plomo depositado en el Museo de Colchester (hallado en Creffield Road) (Wheeler, 1929, 4). Wheeler llama la atención sobre el hecho de que el mismo tubo ceremonial se encuentre en los dos ritos, así como en la fecha de la introducción del rito de inhumación en Gran Bretaña, estimada hacia el año 180. También hacía referencia a los escasos ejemplos existentes en las provincias europeas, citando hallazgos de Lyon, Poitiers, Siracusa, y en los de la ya citada antigua Falerio.

En 1938 Haberey elaboró la relación de los ejemplos conocidos hasta entonces, realmente escasos; fue quien introdujo en el área algunos hallazgos españoles: sierra de las Cabezas (Córdoba), sierra de la Cruz y Poza de la Sal (Burgos).

51 Delattre, De l'utilité d'une mission archéologique permanente à Carthage, Argel, 1881; Gsell, Monuments antiques de l'Algerie, II, 48 (citados por Moretti, 194, nota 2).

52 Sogliano, Notizie degli Scavi, 1886, 334-337; 1887, $451-458$ (citado por Moretti, 194 , nota 3). 
Particularmente interesante fue el hallazgo de una sepultura de inhumación de época bajoimperial, hallada en excavaciones de urgencia, a 350 $\mathrm{m}$ al sur de las ruinas de la ciudad romana de Tauroentum (Saint-Cyr-surMer), tumba a la que ya se ha hecho referencia (véase la p. 107). (Benoit, 1956, 213). El autor galo se refiere a ella como un mausoleo peculiar compuesto de dos cámaras y en cuyo interior había una inhumación. La cámara más profunda guardaba un ataúd de plomo y sobre él había una cámara vacía cubierta por un tejado a doble vertiente, cuya particularidad reside en tres características: ser maciza, estar perforada por un tubo y ser el único elemento del pequeño monumento funerario que sería apreciable al exterior. El mausoleo estaba perforado por un conducto libatorio desde el exterior hasta el sarcófago, primero por un tubo de cerámica y después por un agujero en el sarcófago. La cámara superior estaba revestida de paramento marmóreo. El tubo medía $8 \mathrm{~cm}$ de diámetro y $3 \mathrm{~cm}$ de espesor. Para el autor, la cámara superior correspondía a una cámara de libación, superpuesta a la tumba y que comunicaba con esta y con el exterior. No contenía ningún objeto ni resto de ofrenda. Benoit creyó que con la forma de la estructura de este enterramiento de Saint-Cyr se quiso representar una verdadera «sepultura-casa» y la relaciona con la estela-casa, morada del eidolon del difunto, uno de los tres elementos del cuerpo, distinto del alma y de la materia mortal. Su principal interés reside en la importancia concedida a la cámara de libación. ${ }^{53}$ La mayor parte de los ejemplares de tumbas con conductos libatorios recopiladas por Benoit pertenecen a incineraciones, no a inhumaciones, de África, Liguria y Cerdeña. Sin embargo, recoge las tumbas semicilíndricas de la necrópolis de San Fructuoso de Tarragona, datada en los siglos IV-V, también perforadas por un tubo, esta vez formado por dos tejas para las que Serra $(1944,202)$ descartó una cámara de libación por tratarse de una costumbre pagana (Prudencio, Cathemerinon, $\mathrm{X}$, 169-172) y su función hubiera sido la de recibir una lucerna sin que la apagara la corriente de aire.

A comienzos de los setenta, Wolski y Berciu examinaron los fenómenos de tumbas con bóveda y canal de libaciones a través del material publicado hasta entonces con el objeto de descubrir los elementos susceptibles de fijar el tiempo y el espacio de este tipo de sepulturas, así como de tratar de discer-

53 Sepulturas de este tipo, con conducto libatorio, se conocían entonces en la Galia, en Bibracte, cerca de Tréveris, en Poitiers (cementerio de las Dunes), Vendée (Benoit, 1956, 218). 
nir la condición social y el origen étnico de los que optaron por él. En su estudio, estos autores hacen referencia a un tipo determinado de tumba con bóveda de medio cañón en las regiones litorales hispanas (Cádiz, Belo, Carmona, Tarragona y Barcelona) y lusitanas.

Como sucedía en el caso de las tumbas con bóveda, se plantea también la difusión del tubo de libaciones. Su presencia, aunque indudablemente de origen más antiguo, ${ }^{54}$ alcanzaría máxima popularidad durante los siglos II y III, época en la que los lazos entre la Península Ibérica y África se ponen de manifiesto, tras las excavaciones de las necrópolis de Tipasa, en las que aparecen incineraciones bajo sepulcros de albañilería con conductos libatorios (Baradez, 1968, 77-93, y Fèvrier, Gaspary, 1966-1967). La misma corriente pudo también favorecer la difusión de las tumbas con bóveda en los siglos II y III, etapa en la que, por otra parte, afluyen también elementos orientales. Pero, en el caso de los hallados en Hispania, ¿se trata de influencias africanas?, ¿es una costumbre afianzada o que se afianza en el Mediterráneo?

En Italia, en el caso de Ostia, ya citado, las tumbas de forma de sarcófagos semicilíndricos estaban provistas de orificios y tubos para las libaciones. A veces se trata simplemente de cuellos de ánfora superpuestos, que llevan nombres de procedencia oriental, como en el puerto de Olbia (Cerdeña) (Benoit, 1956) y otros paralelos citados por Wolsky y Berciu, quienes basaron sus informaciones en descripciones de P. Barocelli y N. Lamboglia. Estos autores consideran la utilización del conducto como una característica de la costa o de proximidades del Mediterráneo, haciéndose más extraña cuanto más nos alejamos de él $(1973,377)$. No obstante, recogen tambien los dos casos estudiados por Wheeler en Gran Bretaña: el sarcófago de plomo con un tubo de $90 \mathrm{~cm}$ de longitud hallado en Creffield Road (Colchester) y datado hacia 150 y una tumba de incineración provista de comunicación en Caerleon datada en la primera mitad del siglo II también (110140 d. de C.).

Por otra parte, en la necrópolis de las Dunas de Poitiers se excavaron 21 tumbas casi todas ellas provistas de tubo en un área en la que el rito predominante es el de incineración, mientras que solo hay dos donde predomina la inhumación. En las tumbas con fosa circular el conducto se sitúa en el cen-

54 En 1951, Hatt (1951), 75 presentó este aspecto como parte de un ritual procedente de Grecia y que sería imitado por los romanos. 
tro, en cambio en las de fosa rectangular se encuentra en un extremo. Eygun propuso que la utilización de los tubos fuera abandonada a principios del siglo III (Eygun, 1933).

En la necrópolis de la Puerta de la Sedía de Carmona hay numerosas tumbas de cremación, cubiertas de tegulae en disposición horizontal o de ladrillos en forma piramidal con conducto o en su defecto con una perforación en la tegula, comunicando la cámara hipogeo con el exterior (Belén et al., 1986, 57; Bendala, 1991, 83; Vaquerizo, 2006, 322).55 También hay dos tumbas excavadas en Onuba (Huelva) con fragmentos de ánfora que pudieron servir de tubos de libaciones (Castilla, De Haro, López, 2004; Vidal, Campos, 2007, 22).

Por último, habría que considerar este ritual en un tipo de sepulturas muy numeroso que frecuentemente presentan dispositivo en la Península Ibérica (Tupman, 2005, 119-132; López Vilar, 1999-2000). También en ocasiones los enterramientos en cupae presentan perforaciones libatorias. Caballos ha publicado el hallazgo de una cupa enlucida y pintada de rojo bermellón en la necrópolis situada al nordeste de Itálica, junto a la vía que conducía a Mérida $(1994,228)$. Con motivo de su estudio, este autor ha realizado un estado actual acerca de las características de este tipo de monumentos funerarios en Hispania, abordando los aparecidos en Lusitania, Bética y en la zona catalana, y otro tratamiento profundo se debe recientemente a D. Vaquerizo (2006). Es interesante destacar que la mayor parte de los autores datan estas sepulturas, generalmente de incineración, bien sean monolíticas (cupae solidae) o huecas (cupae structiles) en los siglos II y III d. de C. Así, las casi cuatrocientas cupae solidae graníticas de Mérida, datan de los siglos II y III, ${ }^{56}$ mientras que las catalanas se datan en la segunda mitad del siglo II y el primer cuarto del siglo III y algunas de estas presentan orificio para las libaciones rituales (Juliá, 1965; Bonneville, 1981). Por otra parte, Caballos sugiere que en las necrópolis de Baelo, Gades y Carmo, este tipo de monumento funerario pudo tener un mismo

55 En la nueva necrópolis descubierta a la salida de la puerta Norte de Carmona, se halló un pequeño recinto a cielo abierto, delimitado por muros de albañilería de piedras y fragmentos de ladrillos unidos por mortero, donde se hizo la pira funeraria, con conducto de libación.

56 Bendala (1976). Para este autor, los enterramientos de incineración de Emérita serían debidos a gentes de origen norteafricano, de extracción social liberta y, además, estarían relacionados con el culto a religiones mistéricas. 
origen por sus estrechas relaciones con el mundo norteafricano (1994, 230, 231, n. 25). ${ }^{57}$ Mención aparte merecen las cupae de ladrillo de Baelo por estar cubiertas de estuco y pintadas: algunas tienen conducto de libaciones y se sitúan del 81 al 140 d. de C. (Paris et al. 1926, 69-75). Asimismo, la de Itálica, pese a ser de ladrillo maciza, está revestida de una gruesa capa de mortero y en algunas zonas conserva intacta la pintura de color rojo bermellón (Caballos, 1994, 228).

Nada imposibilita que el fenómeno tratado pudiera también ser producido por un influjo occidental procedente de Hispania o Italia hacia regiones europeas orientales - si bien hay que precisar que no hay eslabones intermedios, con la excepción del de la Madrague de Saint-Cyr-sur-Mer-, pero tampoco puede desestimarse una procedencia oriental. Al respecto, aunque son numerosos los estudios realizados, se echa en falta en ellos no tanto descripciones tipológicas sino las que afectan a su cronología: sería imprescindible contar con dataciones seguras para tratar de establecer un posible origen y su difusión en el Imperio. ${ }^{58}$

\section{Consideraciones en torno a la bóveda y al dispositivo de libaciones}

Al mapa de distribución de tumbas romanas que conjugaban la bóveda y el dispositivo de libaciones realizado por Wolski y Berciu (1973, lám. X, fig. XI) hay que añadir el excavado en Caesaraugusta. Estos autores se percataron de que los enterramientos de estas características están situados, por un lado, a lo largo de las costas de África, Italia, sur de la Galia e Hispania, es decir, en los puntos principales de la ruta de navegación, y, por otro, en lugares del

57 El tipo de enterramiento en forma de cupa se documenta ya en el norte de África a finales de la República, y tiene una larga perduración tanto en incineraciones como en inhumaciones.

58 Los autores rumanos (1970), 962-963 recogieron un área de difusión de los sarcófagos abovedados que abarcaba ejemplos de África; Península Ibérica (aquí desde los primeros siglos del Imperio hasta el Bajo Imperio, con algunas infiltraciones en la Galia Narbonense); la zona de Roma (necrópolis bajo el Vaticano e Isola Sacra [siglos II-III]); Mesia Inferior (cuatro tumbas con bóveda: Kioustendil, Lom y Plovdiv), cuya fecha comprende entre el fin del siglo I y el siglo III; Dacia Inferior (tumbas de Drobeta, siglo III); Dacia Superior (sarcófago de Apulum); Panonia (más tardías, siglos IV-V) se Ságvár (Tricciana). 
interior, en puntos de las vías comerciales terrestres importantes. A esta circunstancia obedece el pequeño monumento de la calle Predicadores: la situación privilegiada de la colonia Caesarangusta debió propiciar la llegada de costumbres particulares, de tipos de tumbas importados. Las intensas relaciones comerciales, sobradamente puestas de manifiesto en las numerosas excavaciones del Centro Histórico de Zaragoza, las políticas, casi desconocidas, y las culturales, entre las que sobresalen las costumbres, los ritos y, en general, todo aquello que conforma el ser humano, se transmitieron también a las formas de las tumbas inspiradas en los mismos prototipos y, además, profundamente romanas. Y sirva como ejemplo, salvando las distancias, la proximidad cultural y comercial de algunas ciudades de la Tarraconense, como Caesaraugusta con Ostia, con más rasgos en común que el mundo funerario - el teatro de Ostia quizá sea el prototipo más adecuado para el de Caesaraugusta, por ejemplo- . No obstante, la ciudad portuaria romana ha sido considerada como el elemento catalizador de los influjos africanos desde principios del siglo II para determinados tipos funerarios (Bonneville, 1981, 36-38).

Finalmente, reiteramos que ambos elementos, el tubo y la bóveda, van unidos, y cabría preguntarse si tuvieron un origen étnico común, o pertenecieron a una condición social determinada que les llevó a preferir este tipo de tumba. Pero los estudios realizados hasta la fecha son escasos, fundamentalmente debido a la prioridad otorgada por los investigadores a la arquitectura funeraria y a que no es frecuente encontrar tumbas de este tipo intactas. Sin embargo, «à l'occasion de chaque nouvelle découverte, le problème est repris, mais la contradiction subsiste entre ceux qui estiment que les tombes avec tube à libations sont un phénomène courant dans le monde romain et ceux qui soulignent la rareté du fait» (Wolski, Berciu, 1973, 371). Quizá habría que matizar esta opinión, ya que las nuevas excavaciones parecen indicar que cremaciones e inhumaciones en tumbas con bóveda se hallan en zonas muy romanizadas, aunque apenas se documentan en el África romana (López Vilar, 1999-2000, 82). Si a esto se suman los dispositivos libatorios y las paredes pintadas, habrá que decantarse por un origen balcánico u oriental (López Vilar, 1999-2000, 80, lám. 12). O se podría postular para este mundo funerario que se tratara de «gentes que quizá hicieron de ellas un signo de autodeterminación social, cultural o incluso de identificación étnica» (Vaquerizo, 2006, 349-50; Tupman, 2005, 125). 
Siguiendo a Wolski y Berciu (1970, 962), se pueden establecer grandes grupos de tumbas con bóveda de medio cañón: por un lado, África y la Península Ibérica (desde los primeros siglos hasta el Bajo Imperio, y con algún ejemplo en la Galia Narbonense), grupo emparentado con el italiano (sobre todo, la zona de Roma con las necrópolis del Vaticano y de Isola Sacra, en los siglos II-III), y, por otro, Mesia (fines del siglo I-III), Dacia ( siglo III) y Panonia (siglos IV-V).

El uso de dispositivos para las libaciones corresponde a un fenómeno muy ligado a la costa mediterránea y, en particular, a la africana, durante los siglos II y III.

\section{Posibles relaciones con gentes de Europa oriental}

Una característica común y peculiar con el de Zaragoza indica ciertas concomitancias con Nórico, Mesia y Dacia: mientras que en los ejemplos africanos, itálicos e hispánicos este tipo de monumento con bóveda son bajos, largos y estrechos, las tumbas de las tres regiones danubianas eran de mayor altura y más anchas (Berciu, Wolski, 1970, 958), evocando sus proporciones el de Caesaraugusta.

El caso de las tumbas monumentales pétreas nóricas ha sido estudiado de forma sistemática recientemente (Kremer, 2001; 2006). Se trata de una gran diversidad que se debió al intenso movimiento de tropas militares a lo largo de la frontera. Entre los cuatro tipos habituales en la arquitectura funeraria de esta zona destaca el edículo (los otros son el baldaquino, el altar y la torre) que de ninguna manera puede compararse al edículo de Zaragoza, a no ser en la elección de esta forma para la memoria del bustum.

Precisamente, es oportuna la observación de G. Kremer respecto a que una ínfima minoría de la población provincial disfrutó de la arquitectura funeraria monumental, ya que la mayoría casi absoluta de la comunidad debía realizar sus enterramientos de forma anónima y sin ningún monumento de la categoría de los que recoge en su estudio y que pertenecían a familias ilustres (Kremer, 2006, 97). Los monumentos modestos y pequeños se hicieron de materiales perecederos como el de Zaragoza, y no se han conservado o no han sido objeto de interés. Las estructuras construidas con técnica de albañilería pertenecía a la tradición local indígena que podía copiar las formas preferidas por los privilegiados. 


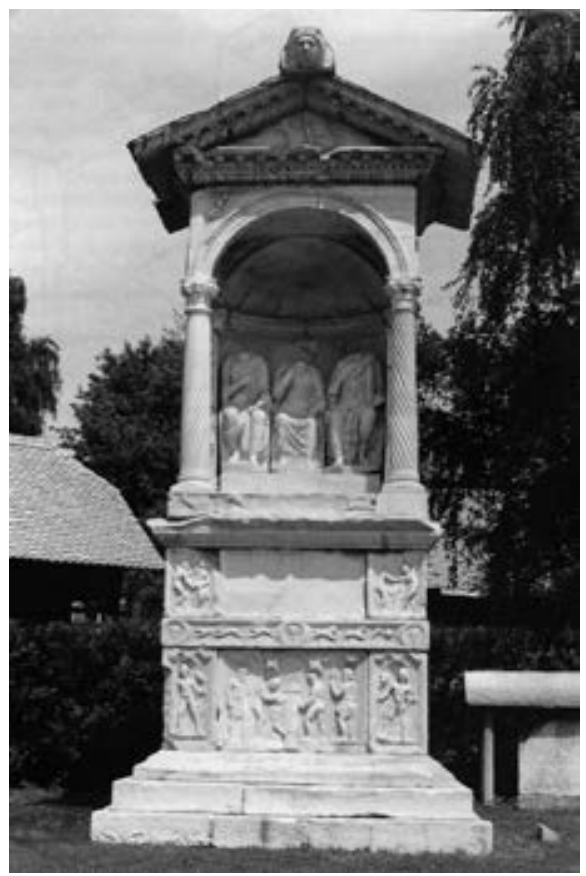

92. Edículo funerario de C. Spectatius Priscianus en Sempeter (Kremer, 2006, 83, fig. 2), de aproximadamente $8 \mathrm{~m}$ de altura.

El edículo con nicho aparece hacia finales del siglo II en Panonia y Dacia. Aquí se trata de edículos pequeños de piedra en cuya base se supone una urna cineraria (Kremer, 2006, 88). Estos monumentos estuvieron muy de moda entre finales de este siglo y el siglo III, un siglo más tarde que sus predecesores de Italia o la Narbonense. Las influencias que pudieron contribuir al relanzamiento de la edícula en las regiones del Danubio Medio pueden proceder del este, de igual modo que ocurre con la plástica de los siglos II y III en Panonia, debido al reclutamiento de tropas orientales en el ejército danubiano (Kremer, 2006, 90).

En este punto puede ser importante recordar aquí posibles relaciones hispanas con Mesia: nos referimos a una inscripción funeraria dedicada a un legionario cesaraugustano a la que se otorga una datación posterior a Trajano, que se tratará más adelante. 
He de admitir que la hipótesis que planteo sobre la posible relación entre este grupo funerario de Zaragoza con gentes del este europeo, ha estado directamente influida por dos estudios que versan sobre aspectos rituales funerarios atribuidos a grupos étnicos de Panonia Inferior y Mesia Superior (Jovanovic, 2000) y del noreste de Panonia (Topál, 2000).

En el trabajo de A. Jovanovic se planteó la determinación de la entidad etnocultural de ciertas prácticas funerarias durante los siglos I-III en el sur de Panonia Inferior y en Mesia Superior. En ambas provincias existen elementos de costumbres locales bien documentadas.

En Panonia Inferior la cremación predomina hasta mediados del siglo III, e incluso perdura en pleno siglo IV, y tanto en cementerios urbanos como rurales. Pero también se practica la inhumación en los mismos lugares, siendo un excelente ejemplo el de Sirmium, en la orilla derecha del Danubio. Se trata de tumbas sencillas que se ocuparon con marinos, mercaderes, soldados, procedentes de Asia Menor en su mayoría, en particular a partir de los Antoninos y de los Severos (Jovanovic, 2000, 205-206).

En Mesia Superior parece que hubo un ambiente funerario similar, aunque algo más complejo, dada la heterogeneidad étnica de esta zona. Fundamentalmente se encuentran aquí incineraciones sin urna y con ella (denominadas «dácicas»), ambas de los siglos I y II. En estas últimas se han hallado fragmentos de cerámicas rotas y a veces trituradas (véanse las pp. 152-154: las tumbas dacias se habrían originado aquí a partir del traslado de población de la Dacia a Mesia Superior a comienzos del siglo i y en el reinado de Nerón. Sus características esenciales perviven hasta el siglo IV: generalmente se trata de fosas con escalón cubierto de tejas y a veces provistas de tubo cerámico libatorio, aunque se trate de incineraciones sin recipiente. Estos rasgos han sido atribuidos a la migración de mineros del este de Dalmacia, sin descartarse que supongan expresiones de una población muy romanizada en Mesia Superior (ib., 2000, 207-209).

La inhumación aparece en Mesia Superior entre finales del siglo I y mediados del siglo III, y prevalece en la segunda mitad del III; no obstante, la cremación representaba todavía el 30\% de los enterramientos. Tanto en Mesia Superior como en Panonia Inferior la incineración predominó hasta mediado el siglo III (ib., 2000, 211).

La procedencia oriental del grupo de Zaragoza podría servir de explicación al hecho de que alrededor de una incineración en este caso (bustum) se 
fueran realizando inhumaciones posteriormente, correspondiendo al fenómeno de la estratigrafía horizontal propia de los cementerios de cualquier tipo: una primera tumba que opera de foco para otras sucesivas (Reece, 1982, 350).

El segundo de los estudios, interesante por diversos motivos, es el de J. Topál (2000). En primer lugar, la investigadora húngara ha comprobado la preponderancia del rito crematorio durante casi todo el Imperio en el noreste de Panonia, y en sus cementerios ha observado características indígenas, como puede ser la ceremonia de purificación previa al enterramiento en el pozo funerario. Este hecho se ha documentado también en Noricum, Dalmacia, Mesia Superior y Dacia: esta costumbre de purificar con fuego el locus sepulturae es atribuida a los ilirios (Topál, 2000, 199). Aunque otras peculiaridades de la cremación en el este de Panonia puedan derivar de grupos étnicos de origen céltico, en el caso citado su procedencia sería debida a un grupo ilirio, los Azali, que fue trasladado en época de Tiberio desde el sur de Panonia al Danubio.

Entre la onomástica de los Azali, precisamente, hay un grupo que indica relaciones con estelas funerarias decoradas con símbolos astrales, incluido el disco solar o ianua coeli (puertas del cielo), de la Península Ibérica, frecuentes en Salamanca. La presencia de elementos ilirio-panonios (no célticos) unida a nombres hispanos, haría posible influencias diferentes a las célticas. Topál encuentra similitud entre las incineraciones de Matrica, Aquincum e Intercissa y considera relevante la aparición de fíbulas noricopanónicas en ajuares de enterramientos más orientales que procederían de las deductiones de veterani (Topál, 2000, 201).

Especialmente interesante es el constituido por una tumba, de inhumación en este caso, hallada en el cementerio occidental de Aquincum (Budapest). En su interior se encontraban los restos de una joven portando una fíbula nórico-panónica (Garbsch A 238 p) en su hombro izquierdo, que constituye el hallazgo más oriental de este tipo, mientras que en su hombro derecho conservaba una fíbula «kräftig profilierte» (Kovrig, 1937, 52, 54; Patek, 1942, IV/12). Para Topál este detalle de la vestimenta de la inhumada sería un reflejo de la tradición y producto de una moda anterior $(2000,201)$.

No hay duda del atractivo de la hipótesis de lo expuesto haciéndola de alguna forma paralela a la Tumba VII de Caesarangusta, en la que fue enterrado un posible militar con una fíbula de este tipo en su hombro derecho. 


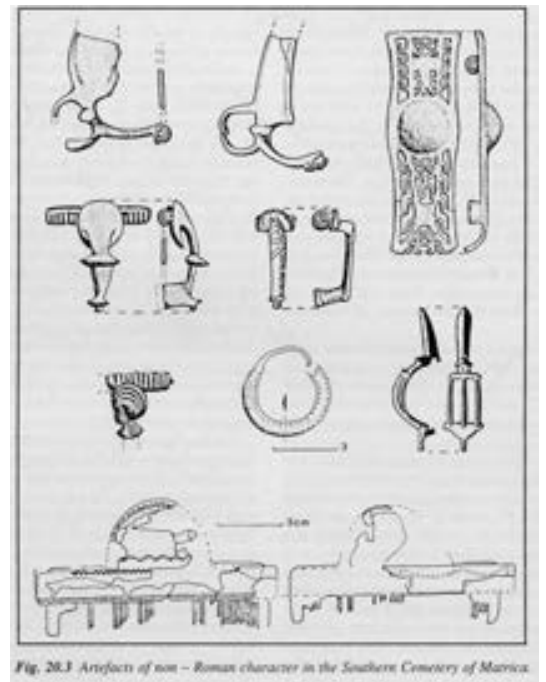

93. Ajuar de discutido carácter romano en la necrópolis sur de Matrica (Topál, 2000, 200).

La presencia en el ajuar de una de las tumbas (VII) de la fíbula de plata apunta a una procedencia de aquella región para la persona que fue inhumada, hecho que debería posiblemente ampliarse al resto de las otras sepulturas que presentaban caracteres tipológicos, topográficos, estratigráficos y arqueológicos, en general, similares. Esta fíbula constituye, además, un unicum en las provincias occidentales del Imperio. El origen del tipo parece estar en la zona de Panonia, noroeste de Noricum y norte de Raetia, donde se localizan en campamentos militares, hallándose en tumbas al norte de los Alpes. Especialmente importante es el conjunto funerario de veteranos en Raetia (Hellsttetener Gruppe) (Fasold, 2000, 187-188). Serían difundidas por el ejército a través del Danubio hacia el este y sur. Corresponde la fíbula de Zaragoza a una evolución del tipo kräftig profiliert, decorado y elaborado en plata de gran pureza. El hallazgo de la fíbula, que por su gran tamaño debió de sujetar un grueso manto, probablemente indicativo de la estación invernal, a la altura de la clavícula derecha (pp. 61-66) en un hombre joven, evoca también otro aspecto funerario muy interesante: las numerosas estelas funerarias que reproducen en relieve la imagen del difunto portando, aparentemente, este mismo tipo de fíbula en aquellas regiones centroeuropeas. 
Por otra parte, hay otro tema en el que queremos de nuevo incidir: la existencia de cremaciones e inhumaciones en un mismo lugar, coetáneas, como ocurre en el grupo de Predicadores. Topál atribuye este fenómeno a que los cambios en los usos funerarios en una misma familia o en grupos humanos se sucederían con gran rapidez:

[...] groups in the north-eastern area of Pannonia, specially women on the evidence of dress accesories in graves and tombstones, tried to protect traditional tribal customs for almost two centuries. Those tribes where inhumation was the ritual also continued to use it side by side with people practising cremation and vice verse (Topál, 2000, 203).

Puesta de manifiesto la miseria de los hallazgos epigráficos en Caesaraugusta, hay que mencionar a un centurión cesaraugustano de la Legión IIII Flavia Felix, hallada en Kostolac, pequeña ciudad serbia a orillas del Danubio, que fue enterrado en un cementerio de la antigua Viminacium (Mesia Superior), ciudad que acuñó sus propias monedas. ${ }^{59} \mathrm{La}$ inscripción es posterior a Trajano debido a la aparición del epíteto felix para la Legión IV, alojada durante un tiempo en el campamento base de la Legión VII Claudia, en Viminacium. ${ }^{60}$ La lápida está encabezada por dos delfines y una cabeza de Medusa y recoge el epígrafe siguiente: L. CAESIVS. L. F. / ANIE FLACCVS / CAESARA. AUG./ C. LEG. IIII. F.F. VIX. / NN.X. (CIL III 14511, Roldán, 318-319).

La argumentación de posibles razones de parentesco formal y ritual entre nuestro grupo funerario y los de las regiones orientales europeas citadas está abierta a discusión. El pequeño monumento ofrece tipológicamente ciertas concomitancias como hemos visto con algunos de Mesia y Panonia, especialmente. Mientras que en los ejemplos africanos, itálicos e hispánicos este tipo de construcción con bóveda es bajo, largo y estrecho, las tumbas dácicas y mésicas eran de mayor altura y más anchas, por lo que resulta fácil percibir parecido con el de Caesarangusta.

Las semejanzas del monumento con bóveda y tubo de libaciones, las tumbas (en especial la portadora de la fíbula, la coexistencia de ritos, el cen-

59 En las acuñaciones de esta ceca son muy numerosas las pertenecientes a Filipo II el Árabe.

60 En la bibliografía suele hacerse referencia a Mantissa en lugar de Viminacium para la ciudad antigua de Kostolac (Fatás, Martín Bueno, 1977, 75; Fatás, 1976, 109-110). 
turión cesaraugustano inhumado en aquella zona lejana al valle del Ebro, la adscripción a un mismo marco cronológico, el siglo III, puede quedar en una hipótesis sugerente; sin embargo, y en espera de razones que hoy por hoy desconozco, parecen lo suficientemente interesantes para su exposición. De ninguna manera se trata de razones concluyentes que, por otra parte, será difícil encontrar.
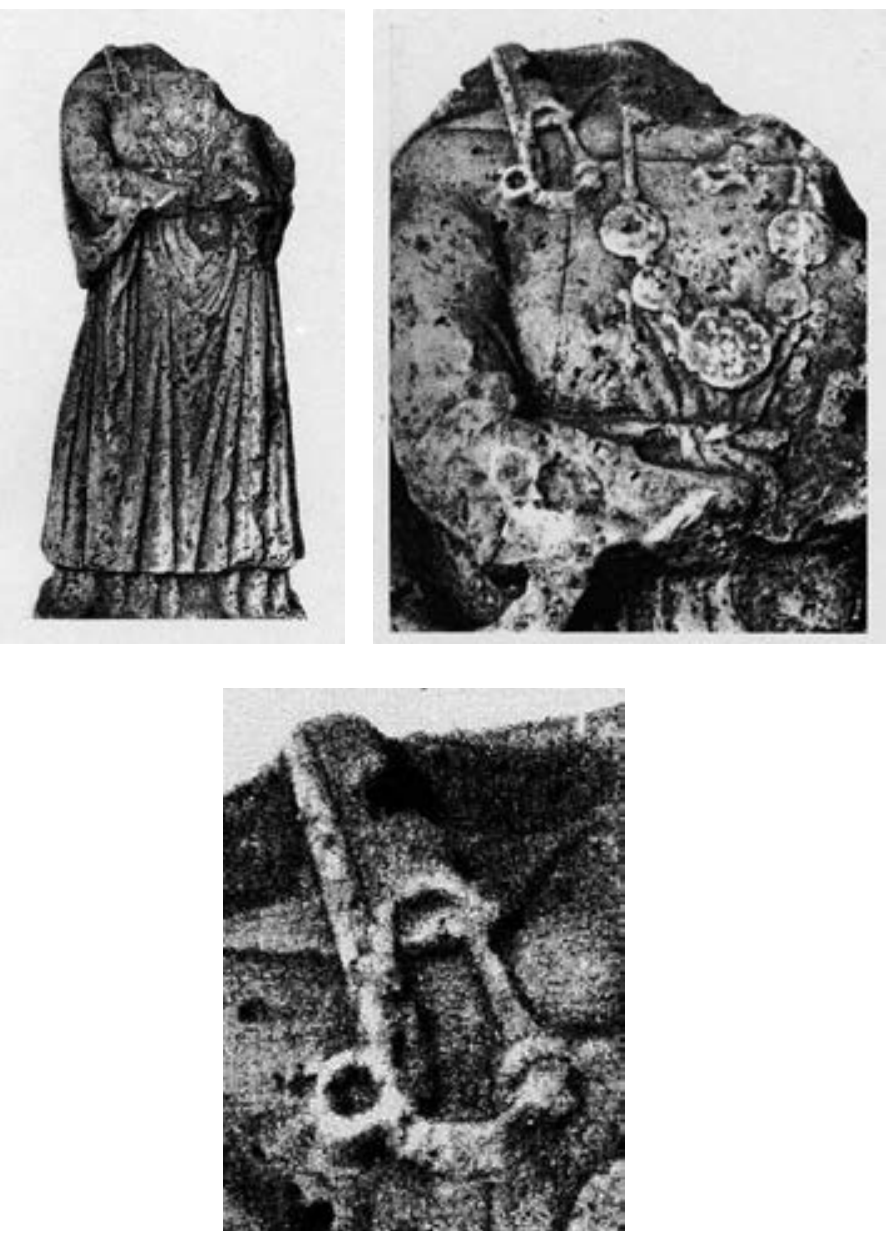

94. Fíbula en estatuaria funeraria (Garbsch, Lám. 15.32). 
Sin duda, si hubiese sido posible el estudio de la epigrafía funeraria latina que debió forzosamente existir en esta ciudad de Zaragoza, que ha destruido casi todo el material pétreo a lo largo de su dilatada vida, podrían obtenerse rasgos célticos; pero todo se queda en un enorme vacío. En la actualidad la investigación concede gran importancia a la detección del rastro que dejaron los grupos étnicos y ello se hace especialmente interesante en lo que respecta al mundo funerario. La gente conserva sus hábitos funerarios en sus desplazamientos; quizá sea este el aspecto que mejor puede apreciarse por sus diferencias y peculiaridades.

Acerca de lo expuesto no hay por mi parte interés en extraer conclusiones. El planteamiento y su relación es hipotético. Aun habiendo puntos concomitantes con etnias tan lejanas, sería necesario ampliar y añadir todos los datos posibles y otros que puedan surgir. 



\section{CAPÍTULO IV PRÁCTICAS FUNERARIAS Y OFRENDAS RITUALES}

\section{La coexistencia de ambos ritos}

Uno de los aspectos que puede contemplarse con mayor interés del conjunto funerario de la Puerta Occidental de Caesaraugusta es el de la coetaneidad o al menos proximidad de los dos rituales romanos, cuestión de plena actualidad en la investigación debido a las excavaciones más recientes. El fenómeno se analizó en exclusividad en un coloquio internacional sobre el mundo funerario de los tres primeros siglos de nuestra era en el Occidente romano. ${ }^{61}$

Por otra parte, el hecho de que se trate de enterramientos y monumentos jalonando la salida de la Vía Decumana de la colonia venía a incidir también en otro punto de partida básico para la investigación en arqueología funeraria, es decir, las Graberstrassen: la integración espacial de las necrópolis en la vida cotidiana mediante la disposición de los sepulcros a lo largo de las vías principales de la ciudad, objeto también de otro Coloquio Internacional celebrado en Múnich (Hesberg, Zanker, eds., 1987).

61 Incinérations et inhumations dans l'Occident romain aux trois premiers siècles de notre ère, Actas del Coloquio Internacional de Toulouse-Montréjeau (IV Congreso Arqueológico de Galia Meridional), 7-10 de octubre de 1987. Sobre el mismo tema se celebró un Coloquio Internacional (Frankfurt am Main, 2004) cuya edición ha visto la luz recientemente, cuando este texto estaba ya entregado (Faber, Fasold, Struck, y Witteyer, dirs., Körpergräber des 1.-3. Jahrhunderts in der Römischen Welt, Internationales Kolloquium Frankfurt am Main (19-20 Nov. 2004). De la parte de Hispania (siglo II a. de C.-siglo II d. de C.) el autor es D. Vaquerizo. 
Sin embargo, en nuestro país ha sido habitual el desconocimiento de temas tales como los citados. Las necrópolis que han sido estudiadas raramente hacen referencia a estos asuntos. En realidad, han sido excavadas de manera parcial, debido a que su hallazgo se ha originado a partir de trabajos de urgencia limitados a zonas sujetas a remodelaciones urbanas, casi nunca en excavaciones sistemáticas en extensión — no es frecuente excavar necrópolis en despoblados, y bien cerca tenemos un buen ejemplo de ello, la colonia Celsa-. Las investigaciones se concentran en los núcleos urbanos al experimentar estos el desarrollo propio de la segunda mitad del siglo XX.

Otra causa de esta laguna de conocimiento ha sido la falta de interés por el estudio de necrópolis hasta hace unos años, ya que este se limitaba a aquellas que contaban con monumentos funerarios y restos destacados arquitectónicamente, careciendo de estudios relativos a los ritos funerarios y más aún a los datos que la concurrencia de la paleoantropología podía arrojar. Por otro lado, es frecuente incluso en la actualidad referencias tales como datación de «época altoimperial» o «visigoda» (o más recientemente «tardoantigua»), sobre todo en informes preliminares de labores arqueológicas de urgencia, sin que jamás se llegue a conocer más datos al respecto. El panorama hispano fue bien reflejado por A. Fuentes:

[...] lo que puede parecer una evidencia — se refiere a una investigación exhaustiva para conocer las sociedades antiguas - apenas está comenzando en mi país, [...] por la ausencia desoladora de estudios de síntesis (Fuentes, 1991, 91).

Sería necesario realizar estudios profundos de análisis para después elaborar síntesis regionales, y hacerlo además sin ideas preconcebidas, teniendo en cuenta que los datos que hasta ahora poseemos demuestran que los ritos permiten variaciones y que los cambios ni se producen bruscamente ni conducen siempre al mismo resultado. Puede suceder que, cuando se estudie, se constaten diferencias incluso en las diferentes regiones, al igual que han podido establecerse disparidades entre la provincia romanizada de la Narbonense y las regiones más alejadas de las tradiciones mediterráneas, como la de l'Ain, el Loira o los Alpes (Bel et al., 1991, 16), diferencias debidas al menos a dos factores: por un lado, a las tradiciones anteriores y, por otro, al grado de romanización alcanzado en las sociedades.

Finalmente, queda una cuestión importante, la relativa a si el paso de la incineración a la inhumación es contemporáneo a este mismo fenómeno en 
otras regiones del Imperio, y si, como hemos visto en el caso de Hispania, hay testimonios de la coetaneidad que se está desvelando con mayor contundencia en las excavaciones urbanas, que son las que generalmente cuentan con áreas funerarias extensas en el tiempo y en el espacio. Para tratar de responder a ello con cierta seguridad, es imprescindible conocer los datos relativos a las provincias vecinas del Imperio, que coinciden también con las áreas mejor estudiadas.

A. Ferdière hizo cumplida referencia a la actualidad del tema en el coloquio celebrado en Tours $^{62}$ en la consideración de las reuniones que ha habido en los últimos años y en el avance de la investigación en esta materia en países de la Europa occidental, en particular en Francia, a la que han venido a unirse Gran Bretaña e Italia.

En las grandes necrópolis de la Galia meridional coexisten en el siglo II el rito de la incineración y de la inhumación, mientras que en el medio rural, los espacios funerarios, posiblemente de utilización familiar y de corta duración, solo han proporcionado incineraciones (Bel et al., 1991, 17). Por otro lado, estas últimas desaparecen preferentemente a finales del siglo II, si bien hay algunos ejemplos de su perduración, datados en el siglo III.

En la región aquitana parece que la propagación de la incineración se produce con cierto retraso en comparación con Roma (Bost, Maurin, 1991, 41-52), mientras que la inhumación es un fenómeno simplemente residual durante los dos primeros siglos de la Era (ib., 1991, 46), generalizándose, al menos en el medio urbano, en el último tercio del siglo III. Al respecto, A. Vernhet $(1991,71)$, a través de su estudio sobre Rouergue extrajo la conclusión de que la incineración había desaparecido totalmente a finales del siglo III.

En el oeste de la Galia (Armórica, Baja Normandía, País del Loira, oeste de la Cuenca de París) (Galliou, 1991, 227-229), ${ }^{63}$ la incineración fue el rito mayoritario en el Alto Imperio y continuó practicándose transcurrida la

62 A. Ferdière se refiere a este tema tan actual en la introducción del Coloquio Monde des morts, monde des vivants en Gaule rurale, Archea/ Ager (Orleans, 7-9 de febrero de 1992), Tours, 1993.

63 Cf. Van Doorselaer (1967), que ofrece un repertorio de dos mil cementerios localizados entre el Rin y el Somme, aunque algunos aspectos fueron puestos en duda por Van Ossel (1991), 209-210, ya que muchos de los datos proceden de excavaciones del siglo XIX. 
segunda mitad del siglo III o incluso en los primeros decenios del siglo IV. Sin embargo, no hay que pasar por alto que hubo también inhumaciones en época altoimperial: en Rouen (Lequoy, 1991, 232), una incineración in situ (bustum) de la primera mitad del siglo III cortaba dos inhumaciones (siglo I o comienzos del II).

En el norte de Italia, donde la romanización de la Cisalpina no se produjo de manera homogénea, se acusan diferencias también en el rito funerario (Rebecchi, 1991, 149-155). Así, mientras que la Lombardía y el Véneto, debido al gran número de inmigrantes, no presentan disparidades culturales con Italia central (Chevalier, 1983, 188), las necrópolis del Piamonte, Liguria y la parte más occidental de Lombardía son algo más retardatarias en la adopción de la inhumación.

Como el tratamiento del tema en la Italia central y meridional podría ser inabarcable, van a tratarse aquí solamente dos centros extraordinariamente significativos: Roma e Isola Sacra. Las dificultades para abordar el tema de la incineración y la inhumación en época imperial en Roma fueron puestas de manifiesto por F. Taglietti - el crecimiento continuo de la ciu$\mathrm{dad}^{64}$ ha impedido casi totalmente que se conservaran sus necrópolis urbanas, constituyendo una excepción las tumbas aisladas que incluso fueron desprendidas de su contexto-, tanto para llegar a afirmar que

... du point de vue de la documentation archéologique c'est justement le contexte romain qui est le moins apte pour identifier le mos romanus, en raison de l'extreme variétè et de la multitude des us et des coutumes coexistants qui caractérisent la ville (Taglietti, 1991, 163).

La autora italiana refuerza la importancia de la inhumación desde el comienzo del Imperio aludiendo a la producción de sarcófagos durante todo el siglo I y su proliferación a partir de los primeros decenios del siglo II d. de C. ${ }^{65}$

En la zona de sepulturas cercana a la Vía Ardeatina, en la Vía de Grotta Perfetta, recientemente excavada, hay inhumaciones en tierra y tumbas en

64 Taglietti (1991), pássim. La necesidad de salvaguardar los monumentos más antiguos ha condicionado el desarrollo urbanístico durante decenios (Steinby, 1987, 106).

65 Taglietti (1991), 174, nota 5, donde recoge opiniones autorizadas en el tema de los sarcófagos. 
capuccina, incineraciones colocadas en pequeñas fosas circulares y en ollae; ha sido datada en el siglo I d. de C. (solo una tumba llega a época de Trajano). De 84 tumbas, 59 son inhumaciones y 25 incineraciones.

Taglietti concluye que la inhumación durante el siglo I d. de C. es un fenómeno de cierta importancia, aunque predomina la incineración. También que el fenómeno afecta a todas las capas sociales: el nivel social no se pone en evidencia por el rito elegido, sino por el tipo de monumento funerario.

De igual manera opina Steinby $(1987,108)$ cuando propone que la elección entre incineración y sepultura, por una parte, y la inhumación -más costosa porque precisa una superficie mayor-, por otra, no se debía a la economía, sino a preferir uno u otro rito, mientras que el nivel de prestigio está definido por el monumento exterior. Así, a propósito de los enterramientos de la Via Triumphalis, plantea la imitación de aspecto modesto de modelos de prestigio como, por ejemplo, columbarios tan reducidos de tamaño en los que el acceso es imposible, o la edícula reducida a la fachada o grabada en una estela. ${ }^{66}$

Por otra parte, hay presencia de inhumaciones masivas en la primera mitad del siglo II en la necrópolis del Autoparco de San Pedro en el Vaticano y en la de la Vía Ostiense, cerca de la basílica de San Pablo (Taglietti, 1991, 167).

La necrópolis de Isola Sacra ha sido frecuentemente utilizada en la literatura arqueológica para establecer porcentajes selectivos de incineración y de inhumación. Los datos que se tenían se han modificado a raíz de las excavaciones recientes: su utilización parte de finales del siglo I a la primera mitad del siglo III continuadamente, prolongándose hasta el siglo IV. En el siglo II es frecuente la construcción de monumentos aptos para recibir ambos ritos en tumbas con cámara cuya estructura arquitectónica es compleja: arcosolia en las paredes y formae en el suelo, pudiéndose usar para ambos ritos a petición de los interesados. Incluso se ha podido documentar la coexistencia de ambos ritos en una misma familia, como ocurre también tanto en las tumbas del Puerto, en las del Autoparco vaticano, e incluso la conservada bajo San

66 E. M. Steinby (1987), 109. Otra característica de la necrópolis de la Vía Trumphalis es la falta de instalaciones para los ritos funerarios, tales como klinai en los muros, siendo que, al menos hasta mediados del siglo II, las tumbas tenían su tubo para libaciones (ib., 106). 
Pedro, que son tumbas familiares de doble rito. En Isola Sacra, de las 72 tumbas estudiadas recientemente, tan solo 12 que datan de mediados del siglo II estuvieron dedicadas exclusivamente a la incineración; ${ }^{67} 26$ presentan los dos ritos, con una cronología a partir de la época de Adriano hasta el año 180 y 28 son casi seguro de inhumación y se datan en los primeros decenios del siglo II o comienzos del III.

En las necrópolis de Alemania se ha apreciado un doble fenómeno: por un lado, los cementerios y monumentos funerarios de tradición itálica, en las vías de acceso a las ciudades, ${ }^{68}$ y, por otro, la perduración de la tradición autóctona céltica en la presencia de rico mobiliario para su utilización en la vida eterna. ${ }^{69} \mathrm{El}$ cambio del rito de incineración a la inhumación se produce a partir de la segunda mitad del siglo II d. de C., adquiriendo cada vez la última más importancia gracias a la influencia de las religiones de redención venidas de Oriente, y sustituyendo a la incineración casi totalmente durante el siglo III. También pudo influir el deterioro económico de la población, que no era capaz de afrontar los altos precios de las ceremonias de incineración (Fasold, 1992, 29).

En territorio belga, mientras que la incineración se originó y fue el rito dominante desde la Edad del Hierro e incluso perduró hasta el siglo III, el rito de la inhumación se impuso a partir de la segunda mitad del siglo II, siendo un fenómeno esencialmente urbano (Van Ossel, 1991, 212).

Una de las provincias mejor documentadas es Britania. Se dice desde hace muchos años que la inhumación se generaliza allí entre el 150 y el 250. Según R. Reece, esto sería en teoría solamente, ya que son todavía escasas las

67 Taglietti (1991), 168. Destaca esta autora una tumba (n. ${ }^{\circ} 87$ ), de época antonina, cuya inscripción prohíbe la introducción de sarcófagos en ella, constituyéndose así en el único caso de rechazo formal a la introducción del rito de la inhumación - a pesar de que todavía no se haya realizado ningún estudio epigráfico global sobre la indicación epigráfica de la dualidad de los ritos.

68 Para dichos monumentos en las Graberstrassen de Tréveris, Colonia, Augsburg y Regensburg, véase «Römische Grabbauten der Nordprovinzen, im 2. und 3. JH.N.Chr.», pp. 291-308, en H. von Hesberg, P. Zanker, Römische Gräberstrassen. Selbstdarstellung-StatusStandard, Múnich, 1987.

69 Cf. la tipología ofrecida por Nierhaus (1959), 17-19, particularmente modélica para este cementerio del sur de Alemania, y A. Van Doorselaer (1967), 92 y 99, donde las incineraciones son clasificadas en Bustumgrab, Urnengrab y Brandschüthurgsgräber ('urna' y 'restos de hoguera'). 
necrópolis excavadas correctamente y publicadas, y que los cementerios estudiados no ofrecen con claridad la transición entre los dos ritos (Reece, 1991). No obstante, los estudios de áreas cementeriales de este país son modélicos en comparación con otras zonas; al respecto, se citan seguidamente algunas de ellas que interesan para esta cuestión:

- Excavación de Ospringe (Kent) (Whiting et al., 1931): 200 incineraciones y 100 inhumaciones. Ambos ritos están asociados a cerámicas t. s. de finales del siglo III.

- Chichester (Down, Rule, 1971): de 326 sepulturas solamente 9 eran inhumaciones y una de estas se encontró bajo una tumba de incineración. La datación es difícil a pesar de que se encontraron algunas cerámicas susceptibles de una datación en el siglo III.

- Cirencester y York: modélicamente excavadas y publicadas, a pesar de que las características del subsuelo dificultara enormemente la distinción de las tumbas. En Cirencester (Whirr et al., 1982), de 450 inhumaciones solo hay 3 incineraciones y en Trentholme Drive (York) (Wenham, 1968) se hallaron 53 incineraciones y 350 inhumaciones.

- Skeleton Green (Hertfordshire) (Partridge, 1981): de 57 tumbas, 52 incineraciones y 5 inhumaciones.

- Lankhills (Winchester) (Clarke, 1979b). Se han reconocido incineraciones en el siglo IV.

- West Tenter Street (Londres) (Whytehead, 1986): zona cementerial situada probablemente junto a una vía, con 120 inhumaciones, 14 cremaciones (bustae) y 7 urnas cinerarias. Cremaciones e inhumaciones se llevan a cabo desde principios del siglo II, continuando la cremación en el III y la inhumación continuó hasta mitad del siglo IV o incluso más tarde. Se identificaron dos posibles monumentos.

La problemática que algunos autores plantean para Gran Bretaña se basa en que los métodos para datar la cerámica de finales del siglo II o comienzos del III pudieran haber sido erróneos (Reece, 1991, 222), y, precisamente, estos parecen ser los años cruciales para el cambio de rito. Además, no se ha realizado ningún estudio general y la única solución posible pasa por la elaboración de trabajos regionales profundos antes de lanzarse a estudios 
más ambiciosos. Las ideas preconcebidas, por otra parte, pueden enturbiar cualquier intento de estudio objetivo; al respecto, hay tópicos que habría que evitar, como que cualquier incineración sin urna se atribuya al siglo I o II, o que cualquier esqueleto sin mobiliario siempre «será » del III o IV. Otra cuestión es saber hasta qué punto los datos recogidos son representativos de los ritos funerarios de una comunidad. En realidad, estas reflexiones podrían hacerse extensivas también a los estudios sobre el mundo funerario hispano.

En el antiguo Magreb se conoce de manera un tanto deficiente la utilización de los dos ritos funerarios (África Proconsular, Numidia y Mauritania Cesariana y Tingitana) y los datos que se poseen sobre su coexistencia constituyen todavía un tema en estudio. Así, sería necesario conocer mucho más la influencia que la Sicilia griega ejerció sobre el mundo púnico, y mucho más, contando con la utilización de cremaciones e incineraciones durante los siglos III y II a. de C.; es decir, que la zona africana estaba ya habituada a la práctica de ambos procesos (Fèvrier, 1991, 181-189).

Otro problema viene a sumarse a las deficiencias apuntadas, por otro lado común a las zonas que han conservado monumentos funerarios en el mundo romano, y es el hecho de que los arqueólogos se han dedicado más a estudiar el material que el propio rito. Buen ejemplo de ello se halla en Tipasa donde, no obstante, se conocen algunos monumentos funerarios pequeños de época flavia y antonina que han proporcionado incineraciones (tumbas situadas en Tipasa en el oeste de la puerta de Caesarea, al norte de la vía) (Lancel, 1970). Lo que sí parece cada vez más evidente es que la introducción del rito de la inhumación como fenómeno exclusivo va íntimamente unida al impacto romanizador sobre los habitantes de las diferentes provincias, tanto en los inicios como en los siglos posteriores. Para P. A. Fèvrier $(1991,185)$ el fenómeno de la reaparición de la inhumación como rito dominante tiene tres ejemplos representativos: las necrópolis de Sitifis, Tipasa y Raqqada. En Sitifis son muy numerosas las incineraciones in situ, sin que se haya decidido si se trata de un fenómeno autóctono o romano. ${ }^{70}$

En Tipasa (Mauritania), las últimas incineraciones parecen ser de comienzos del siglo III (Guéry, 1967; Fèvrier, Gaspary, 1966-1967; Fevrier,

70 La ciudad de Sitifis, fundada en el reinado de Nerva (96-98) como colonia militar mediante el reparto de grandes extensiones cerealistas, subyace bajo la moderna Setif y se ha excavado parcialmente. Véase Fèvrier (1965). 
Guery, 1980), aunque algunas se han datado en el segundo cuarto del siglo III (Bouchenaki, 1975, 66). En la necrópolis occidental hay un área que parece que se desarrolló alrededor de un mausoleo donde se descubrió una incineración y bajo ella había dos inhumaciones.

Finalmente, y en el estado actual de los conocimientos, la datación del paso de la incineración a una inhumación en exclusiva es todavía difícil de precisar para el Magreb (Fèvrier, 1991, 187).

El panorama que podría ilustrar el paso de la incineración a la inhumación es todavía deficiente debido a la escasez de estudios dedicados a los ritos de las necrópolis de la Hispania romana. El conocimiento es muy parcial y, por lo tanto, incompleto. Algunas necrópolis fueron destruidas, otras solo son conocidas por antiguas excavaciones - que, como es lógico, son las más monumentales-, de las que bien pocos datos pueden extraerse para el tema que nos ocupa: en su mayor parte, los arqueólogos estaban más interesados en el estudio de sus grandiosos monumentos que en la descripción de las peculiaridades del rito utilizado.

En la Hispania meridional cuenta con importantes conjuntos de carácter funerario - Belo, Cádiz, Carmona, Castulo, Mérida-. Sin embargo, dos de los más sobresalientes - Belo Claudia y Carmona- fueron excavados en su mayor parte a principios del siglo XX, es decir, careciendo de una metodología de la cual dispone actualmente la arqueología funeraria (Bendala, 1991; Caballos, 1994; Vaquerizo, 2006). No obstante, existe una opinión generalizada a considerar la tradición anterior púnica de la zona (Bendala, 1991; Sillières, 1995). ${ }^{71}$

Para Belo, P. Sillières ha propuesto la datación del cambio de rito funerario durante la segunda mitad del siglo II $(1995,202)$ tras el estudio del material arqueológico, aportando importantes ideas relativas a la adopción y el abandono de ambos ritos. La impronta cultural púnica permitió que la inhumación perdurara hasta mediados del siglo I d. de C.: una tumba de inhumación, con una moneda de Claudio, se descubrió en la necrópolis oriental bajo sepulturas de incineración. Pero el rito de los siglos I y II parece haber sido la incineración, siendo problemático el momento de adopción de

$71 \mathrm{Al}$ respecto, Bendala (1991), 80-81, analiza las prácticas funerarias de colonizadores e indígenas del territorio meridional de la Península Ibérica. 
la inhumación, aunque el autor apunta a la primera mitad del siglo II en el caso del recinto XIII, mientras que en la necrópolis oriental la norma durante el siglo III fue la inhumación.

En Carmona, el conjunto de tumbas de incineración excavadas corresponde al siglo II, con una mayoritaria presencia de monedas de época de Adriano y Antonino (Bendala, 1991, 83).

En Cástulo, el sector de la puerta norte proporcionó hallazgos de incineraciones que J. M. Blázquez dató por criterios numismáticos en época tardía. No se corresponde con la opinión de A. M. Canto y de M. Bendala, que apuntan a que estas monedas no aparecieron en el mismo contexto de los enterramientos, sino en posteriores niveles de ocupación (J. M. Blázquez, 1975, 237 y ss.; A. M. Canto y J. J. Urruela, 1979, 323; Arce, 1979b; Bendala, 1991, 84).

En la necrópolis este de Munigua (Córdoba) se excavó un monumento con bóveda interior y tejadillo a doble vertiente que encerraba 3 cremaciones y 2 inhumaciones: constituye un excelente testimonio del uso de los dos ritos en un mismo núcleo funerario familiar (Schattner, 2003, 113; Vaquerizo, 2006, 304).

Para el caso de Emerita (Mérida, Badajoz), ${ }^{72}$ al tratarse de una ciudad construida ex novo, se contempla una adopción de las costumbres romanas desde el principio, y, efectivamente, parece que la incineración se data desde los primeros momentos, si bien parece que en algún sector oriental de la necrópolis sudeste aparecen tumbas de inhumación mezcladas con las de incineración (Marcos Pous, 1961, 96; Bendala, 1991, 86). ${ }^{73}$ Excavaciones recientes en una ciudad actualmente en expansión han propiciado la posibilidad de trabajos arqueológicos en extensión a menudo y con un registro de datos modélico (Departamento de Documentación del Consorcio de Méri-

72 Mélida (1925); Floriano (1935); ídem (1944), 169-172; Bendala (1976); J. M. Álvarez y Sáenz de Buruaga (1943); García y Bellido (1962), una decena de edículos de planta cuadrangular más o menos, que afloraban a uno u otro lado de la calzada antigua que coincidía en este tramo con la carretera moderna. Se trataba entonces del primer caso aparecido en España de «una necrópolis romana de carácter monumental al modo de la Vía Appia (p. 3)». Parece que no tenían techado y son de mayor tamaño.

73 García y Bellido $(1962,5)$ al dar cuenta de varios edículos funerarios excavados en la carretera de Mérida a Sevilla, explica la aparición de enterramientos de inhumación dentro y fuera de las construcciones funerarias como prueba de que ya habían sido abandonados. 
da). Juana Márquez ha realizado un recorrido por el paisaje funerario de esta ciudad en los tres primeros siglos, a partir de las vías documentadas en la periferia de Mérida (Nogales, Márquez, 2002, 114-122). Este paisaje contaba, además, con instalaciones industriales y arquitectura doméstica, al igual que ocurre en Caesaraugusta, poniendo en tela de juicio la supuesta «corona» funeraria emeritense que habría que situar en época ya cristiana, al rellenarse los espacios intermedios que habían quedado vacíos (ib., 2002, 115). Parece que la incineración se desarrolla durante los siglos I y II, conviviendo con la inhumación en el II y llegando esta a ser única a partir de los siglos III-IV. En cambio, en otros centros urbanos del sur la inhumación parece no generalizarse hasta el siglo III debido al fuerte sustrato púnico en un amplio territorio del sur de España que se perpetúa en las costumbres funerarias hasta mucho tiempo después, como sucede en Carmona y Cádiz (Bendala, 1991, 87). ${ }^{74}$

Un caso aparte está constituido por el mundo funerario de Córdoba, que hasta hace poco tiempo parecía todavía por descubrir (Vaquerizo, 1994, 416-417) y que se ha ofrecido en un estudio completo (Vaquerizo [coord.], 2001; Vaquerizo, 2002; Vaquerizo, Garriguet, León, 2007). En Corduba se mantiene la incineración hasta finales del siglo II o comienzos del III (Vaquerizo, 2002, 156; 2001, 146)..$^{75}$ De especial interés para el tema son un hipogeo, datado hacia el cambio de era (c/ La Bodega, necrópolis septentrional) en el que fueron enterrados un individuo incinerado y otro inhumado, así como varias inhumaciones entre 50 cremaciones de la necrópolis La Constancia (Vaquerizo, Garriguet y Vargas, 2005). Vaquerizo advierte que últimamente se viene observando que en muchos casos la inhumación fue traída a Hispania por algunos de los primeros colonos itálicos, llegados de regiones donde constituía precisamente el rito funerario predominante. Esta coexistencia de ambos ritos desde los inicios de Roma como potencia colonial, no solo en Hispania, sino también en la propia Italia, podría ser indicativa de que el triunfo definitivo de la inhumación en el siglo III no supondría «normalización ritual» (2006, 330-331, nota 43).

74 También hace referencia a este fenómeno en Belo, hecho que P. Sillières no parece compartir.

75 D. Vaquerizo ha establecido una tipología de los usos funerarios de Córdoba (inhumación e incineración) muy útil a la generalidad del mundo funerario romano carente de monumentalidad, es decir, el rito puro que utilizaron las gentes modestas (Figs. 6, 7 y 8, 2002). 
En este mismo sentido merece destacarse también la investigación en el País Valenciano (Ribera, 1996; González Villaescusa, 2001, pássim). Aquí se ha propuesto el tránsito de la cremación a la inhumación en la primera mitad del siglo II (González Villaescusa, 1993, 412-414; 2001, 77).

En Sagunto (Valencia) la necrópolis oriental, situada en la Vía Augusta en dirección a Valentia, contaba con enterramientos pertenecientes a los dos ritos, así como abundantes monumentos funerarios, sin embargo, por tratarse de hallazgos antiguos, son escasamente conocidos (Olcina, s. d.).

En la ciudad de Valencia se desconocían áreas cementeriales que presentaran una coexistencia de ambos ritos. De los pertenecientes a inhumaciones en la Boatella, antiguo barrio islámico extramuros, cuyo hallazgo data de 1945, se ha estudiado el material y estimado una datación en el siglo III (VV. AA., 1984, 20). También se datan en esta centuria los restos en fosa de la necrópolis meridional del Portal de Russafa (Ribera et al., 1989, 39). En la actualidad, las numerosas excavaciones arqueológicas realizadas han propiciado nuevos datos para diversas áreas de la ciudad romana que cuentan con necrópolis de los siglos I-III: al sudoeste (la Boatella), al oeste (calle Verge de Misericòrd), al sur (calle San Vicente Mártir i de Russafa) y al norte (avenida de la Constitució) (Aranegui, 1996, 181). Entre ellas merecen destacar las excavaciones de la Misericordia, con enterramientos datados entre la segunda mitad del siglo I a. de C. y el III d. de C. (Rosselló, Ruiz, 1996a, 1996b). Mención especial merece en esta misma área la excavación de la necrópolis de la calle Quart, con una convivencia de ambos ritos hasta el siglo III (García Prósper, Guérin, 2002, 211-214).

Como puso de manifiesto A. Fuentes (1991, 91-106), las grandes diferencias entre los habitantes de la mitad norte de la Península en el grado de romanización alcanzado son causa también de la diferente adopción de los ritos funerarios romanos por parte de estos. Así, mientras el valle del Ebro evidencia una romanización temprana, otras zonas, como sucede en la Meseta, son algo más retardatarias. Aquí, en la Meseta, el substrato de culturas anteriores, cuyo uso funerario era la incineración, sirvió de fondo cómodo para el rito que implantaron los romanos en un principio. En esta zona, al igual que ocurre en el valle del Ebro, se conoce con detalle el ritual de la fase prerromana y a partir de época tardorromana, habiendo un vacío de estudio de las necrópolis en época imperial. 
En la zona citada se cuenta con dos necrópolis muy valiosas: Palencia (las necrópolis Sur y Eras del Bosque [Taracena, 1948; Simón y Nieto; López Rodríguez, 1970; Balil, 1983] y Segóbriga (Almagro Basch, 1977). Respecto a los dos conjuntos palentinos escasos datos se han podido sacar, ya que fueron expoliados. En la necrópolis de las Eras del Bosque la incineración era mucho más abundante que la inhumación y su ajuar abundante. Sin embargo, las inhumaciones estaban desprovistas de objetos por lo que la datación es complicada.

En las cercanías de Madrid se conoce la necrópolis de incineración de La Torrecilla (Getafe), de cronología un tanto imprecisa, ya que según sus autores habría perdurado varios siglos hasta el siglo III; sin embargo, no se tienen noticias de inhumaciones (Lucas Pellicer et al., 1982, 238).

A. Fuentes (1991) ha puesto de manifiesto que las tumbas más antiguas del área serían aquellas incineraciones efectuadas con arreglo al ritual romano, datadas en Segóbriga en época claudio-flavia. Sin embargo, si estructuralmente son romanas, no ocurre lo mismo con los objetos que en ellas aparecen, que pueden considerarse de tradición indígena por la cerámica y por la abundancia de ajuar, que contrasta con el uso romano. La fase de coexistencia de incineraciones e inhumaciones parece producirse desde el siglo II, ${ }^{76}$ en un momento de difícil precisión se produce el paso a la inhumación como rito funerario exclusivo (tras el siglo III florece una fase tardorromana bien conocida de la Meseta).

El noroeste peninsular carece de significado para este momento, ya que se tratan de testimonios aislados. En general, el rito funerario practicado por los castreños del noroeste tiene perduración a pesar de que haya indicios de «romanización material» (Fuentes, 1991, 102) —introducción de objetos romanos en las tumbas - y continúan enterrando en el interior del castro. Se añade a esto que hubo también una adopción de elementos completamente romanos, como son las estelas funerarias de gran importancia epigráfica (Fuentes, 1991, 105, n. 68). La adopción de la costumbre funeraria romana debió producirse en la zona precisamente con la introducción de la inhumación, hecho que parece ser ya de época romana tardía (Fuentes, 1991, 106, n. 69).

76 Uno de los primeros testimonios data del siglo II d. de C. y se trata de una sepultura con sarcófago de plomo descubierta en Toledo (Palol, 1972, 133 y ss.). Y otro sarcófago de plomo con mobiliario, datado entre el II y el III (Fernández Galiano, 1976). 
El área del noreste y el valle del Ebro fueron pronto y profundamente romanizados.

En Ampurias fueron habituales la incineración y la inhumación (Almagro Basch, 1953; 1955; Almagro Gorbea, 1962). Los ampuritanos emplearon los dos ritos ya desde época antigua: el rito funerario helénico era la inhumación y el ibérico la incineración. En época romana parece haber dos fases separadas por el reinado de Augusto. En la etapa republicana se aprecia un conservadurismo en el ritual y una lenta adquisición de las costumbres romanas. Así, en la necrópolis Bonjoan la incineración se hace predominante en época cesariana — a partir de la reforma de la ciudad en el 49 a. de C.—; lo mismo puede decirse de la necrópolis de Las Corts, donde el uso es ya estrictamente romano y se ha advertido cierta concordancia entre reminiscencias ibéricas y acomodación romana, en detrimento de la tradición griega anterior (Fuentes, 1991, 94).

A partir de Augusto se abre una nueva etapa en el mundo funerario ampuritano: necrópolis Ballesta-Rubert, Torres-Nofre, necrópolis meridional y del sudeste. Aparecen clavos que indican cajas de madera, ${ }^{77}$ bustae, cistas de tegulae y pequeños monumentos funerarios en forma de «dado», estucados de rojo. Es en estas necrópolis donde se produce la introducción del rito de inhumación. $\mathrm{Al}$ respecto, hay que tener en cuenta la profunda tradición funeraria de inhumar de origen griego, y, por ello, la perduración de las tumbas de este tipo en todas las épocas y la dificultad para atribuir una datación del cambio de un rito a otro en esta ciudad, ya que la inhumación no fue nunca abandonada.

La inhumación más antigua de la necrópolis Ballesta-Rubert se dató en época de los Antoninos, mientras que las incineraciones más tardías se sitúan en el siglo II (Ballesta 47) con una moneda de Trajano (104-110 d. de C.) (Almagro Basch, 1955, 22). Pero, aparte de la posibilidad de datar en el primer tercio del siglo II el punto de partida de la inhumación, debido al empobrecimiento del ajuar fúnebre, pocos datos más pueden tenerse como seguros, ya que las necrópolis romanas que existen en el siglo III presentan todas ya el rito de la inhumación (Fuentes, 1991, 96).

El mundo funerario de los primeros siglos en Tarraco se ha visto enriquecido con hallazgos sumamente interesantes durante los últimos años. ${ }^{78}$

77 Vid. las pp. 148-149.

78 Una visión de conjunto puede consultarse en Gurt y Macías (2002); Remolá (2004), 83-95. 
En la zona de poniente de la ciudad se han descubierto numerosas incineraciones de estructura muy sencilla, bien sea con urna cineraria o sin ella. Se tiene noticia del hallazgo de un monumento funerario en la calle Rovira i Virgili, datado a finales del siglo I e inicios del II, que presentaba ambos ritos (Terre, 1993, 260). La coexistencia de enterramientos de incineración e inhumación se documentó también en la excavación de la calle Robert Aguiló, n. 38 (Arbeloa, 1993, 254), ubicada en un área suburbana oriental, datada desde época de Tiberio hasta el siglo III, contando con inhumaciones del siglo I e incineraciones en ollas de finales del II-principios del III. Hacia el este, la zona cementerial dels Cossis aporta datos importantes sobre los ritos funerarios, con un uso predominante de la inhumación durante los siglos II y III, como en la citada anteriormente (Arbeloa, 1995): uso de tejas, sarcófagos de plomo y madera, y dispositivos para libaciones; asimismo, se ha observado la existencia de enterramientos aislados o en grupos pequeños (Gurt, Macías, 2002, 91), que quizá puedan paralelizarse al grupo de Predicadores.

En la vía que pasaba por delante del circo hacia el puente del Francolí (Camí de la Paret Alta), en una zona con infraestructuras hidráulicas, se ha localizado una tercera área funeraria: un pequeño mausoleo e incineraciones e inhumaciones aisladas (Gurt, Macías, 2002, 91).

En conclusión, se viene documentando en Tarragona a través de las excavaciones, la coexistencia de ambos ritos con predominio de la inhumación a partir del siglo II (áreas funerarias de Robert Aguiló, del Camí de la Platja dels Cossis y de la vía del Francolí) (Arbeloa, 1995), mientras que en la zona oriental coinciden enterramientos en el tiempo y en el espacio con hábitats residenciales. A partir de finales del siglo III el mundo funerario de esta ciudad es bien conocido.

En Lérida (Ilerda), con motivo de la construcción de la estación del ferrocarril en los años veinte se localizaron sarcófagos de arenisca, enterramientos en tejas y en ánforas, que parecen datarse en época bajoimperial (Pérez, 1991, 30-33). Por otra parte, se excavaron una docena de enterramientos, que pertenecen casi todos a recién nacidos (Loriente y Oliver, 1992). Curiosamente, 7 de estos bebés tenían un vasito que guardaba en su interior las cáscaras de huevo. ${ }^{79}$

79 También en la necrópolis de Can Trullás (Granollers, Barcelona) se hallaron jarras con huevos en su interior, y en la vía funeraria de la plaza de la Vila de Madrid (Barcelona) se encon- 
En lo que respecta a Navarra, siguen sin localizarse áreas de necrópolis a pesar de las numerosas excavaciones realizadas en Pompaelo (Pamplona). En cambio, se han excavado dos necrópolis de incineración en Iturissa (Espinal), mansio junto a la vía 34, mencionada por Ptolomeo (Pérex, Unzu, 1988, 335-339): una de ellas con 49 urnas ( 4 son de vidrio), datada en la segunda mitad del siglo I y primera mitad del siglo II, situada fuera de la población y junto a la vía, y la otra a $900 \mathrm{~m}$ de la anterior, con 43 urnas (una de vidrio) y dos busta en Otegui (Espinal), de los siglos I y II (con fragmentos de urnas, huesos y cenizas). Las dos necrópolis son simultáneas y tienen características comunes. Por otra parte, en Eslava, se han excavado tres monumentos funerarios de sillarejo, recubiertos de estuco coloreado en el interior y exterior. En el interior había dos niveles de incineración, no había urnas y los restos carbonizados se encontraron esparcidos. No tenían ajuar, pero sí que se localizaron clavos de hierro - ¿de la pira? - y muchas chinchetas de bronce que podrían haber pertenecido a los recipientes de madera en los que se introdujeran las cenizas (Unzu, Pérex, 1997).

En Guipúzcoa, en la necrópolis de Santa Elena, se utilizó la incineración, y fue datada del 50 al 150. Se documentaron dos estructuras funerarias: un monumento de tres metros de lado que contenía en su interior una urna cineraria (Drag. 37, de la primera mitad del siglo II), y otro recinto compartimentado en el interior, de siete por tres metros y medio, que se utilizó durante una época muy dilatada, ya que aparecieron monedas medievales (siglo IX) (Barandiarán, 1973, 85-91).

En el valle medio del Ebro contamos con una abundante bibliografía de monumentos funerarios, ${ }^{80}$ fenómeno que también se daba en los estudios sobre las grandes necrópolis de la Bética, pero en realidad muy poco sabemos de los cementerios y de los ritos en ellos practicados. Núcleos urbanos antiguos como Celsa (Velilla de Ebro, Zaragoza), o Bilbilis (Calatayud, Zaragoza) que llevan ya muchas campañas de excavación y que han sido ya objeto de estudios importantes no han dado frutos todavía en el aspecto funerario.

tró una cazuela de cerámica africana con huevo y moneda, estando el huevo con restos de paja que debió introducirse para mantenerlo en pie (Beltrán de Heredia, 2007, 50). Este ritual que se encuentra también en el mundo ibérico tiene perduración en la época islámica. En esta misma zona de Predicadores, una tumba conservaba en su interior un huevo de gallina encerrado cuidadosamente en una pequeña orza (Galve, Benavente, 1992, 388). En conclusión: esta costumbre tiene una amplia perduración, ya que se usa en época ibérica, romana e islámica.

80 Para una actualización del tema arquitectónico, Cancela (2002). 
Caso aparte es el constituido por los monumentos funerarios expoliados o destruidos hasta el punto de que es imposible deducir el rito. Aun cuando se hayan conservado soportes con epígrafes parece difícil la adjudicación a uno u otro ritual. Se han analizado diversas fórmulas utilizadas que indican necesariamente la presencia de una inhumación, tales como membra, exanimem corpus, si bien no puede asegurarse con total certidumbre (Bonneville, 1984; Bost, Maurin, 1991, 44-45; Vismara, 1991). Otra cuestión es si la transformación del rito funerario ha favorecido el cambio de la tipología de monumentos que no sean sarcófagos, es decir, ¿desaparecen las estelas, cipos, altares que protegían e indicaban la presencia de una incineración? Al respecto, Picard (19651966, 159-160) explicó la desaparición de algunos monumentos en Túnez a causa de la evolución de los ritos funerarios y, por su parte, Andreae (19681969, 145-166) indicó que, en Roma, los sarcófagos sustituyeron a los altares funerarios, conservando aquellos los motivos decorativos de estos.

\section{La orientación de las sepulturas}

La planimetría de las tumbas de este grupo, incluidas las estructuras funerarias de las Incineraciones I y III guarda una adecuación a la alineación de la calzada que provenía de la Vía Decumana, la más importante de la ciudad romana. En esta dirección se sitúan también las estructuras de la casa que anteriormente hubo allí. La orientación de esta vía y del resto de los decumani paralelos a ella es de $136.45 \mathrm{~g}$ (Escudero, Galve, 2006, 191), orientación que ya tenía una casa de tipo itálico de la ciudad indígena de Salduie, anterior a la fundación de Caesaraugusta (Galve et al., 1996, fig. 9). De lo dicho puede deducirse cierta ordenación topográfica en el área funeraria, tanto para las estructuras correspondientes a las cremaciones como a las fosas de inhumación. Respecto a estas últimas, de las 11 conservadas (excluyendo las infantiles con excepción de la I), 9 presentan el lado largo de la fosa paralelo a la calzada. La orientación de los individuos en 5 casos (I, IV, VII, VIII, XI) era SE-NO (entiéndase la cabeza hacia el NE) y en 2 NO-SE (IX y X). La fosa de la Tumba III guardaba disposición SO-NE (con la cabeza en el SO); esta peculiaridad se debió, sin duda, a su situación paralela al muro oriental del mausoleo.

Así pues, la organización espacial en el plano de las estructuras funerarias de esta necrópolis ofrece predomino de la dirección NO-SE en sus enterramientos, mientras que la edícula se abría al suroeste. Las leves variaciones de 
las otras fosas estarían causadas por su adecuación al espacio. Al respecto, de las conclusiones aportadas por exhaustivos estudios de cementerios de época romana en los que aparecen los dos ritos, se deduce que, tanto en el caso de las incineraciones - cuando están protegidas de alguna estructura-, como en las inhumaciones, la intención de la orientación de los enterramientos es arbitraria. No se rige por norma alguna, como podría esperarse según la tradición que se ha transmitido, sino que obedece más bien a la situación de la vía de salida de la ciudad, de las vías funerarias o de la existencia de algún monumento al abrigo del cual fue ampliándose la necrópolis. Es más, en algunos casos se ha podido constatar la presencia de un muro paralelo a la vía que parecía delimitar el área funeraria y que protegía monumentos, incineraciones e inhumaciones. En el caso de las incineraciones es frecuente que se aglutinen en torno a los ustrina, aunque no parece haber sectores reservados a uno u otro rito según se viene documentando en las modernas excavaciones, como es el caso de Fréjus Saint-Lambert (Bel et al., 1991, 18).

Tratar la orientación en el ritual de la incineratio podría parecer incomprensible, sin embargo, han podido extraerse algunos datos de las incineraciones in situ de Sitifis (Magreb): los cuerpos fueron quemados con la cabeza hacia el este mirando al oeste según la orientación tradicional de las inhumaciones más antiguas, y esto quizá no fuera un fenómeno exclusivo de África (Fèvrier, 1991, 184). Sin embargo, en términos generales este detalle es imposible de comprobar, ya que la mayor parte de las cremaciones son objeto de un depósito secundario, por lo que tan solo podría quizá suponerse que el cadáver se dispondría en la pira funeraria con una orientación determinada.

Pero ni siquiera esta orientación es segura para el caso de inhumaciones, sino que, todo lo contrario, las opiniones al respecto son variadas y divergentes. Así, mientras que generalmente se aceptaba que en un principio el sentido era norte-sur y más tarde, este-oeste, las investigaciones más recientes ponen muy en duda esta norma, ya que cuentan con ejemplos de ambas, y además, coetáneos (Bel et al., 1991, 21). Buen testimonio de ello son las tumbas del grupo de Predicadores en las que, aunque predomina la orientación $\mathrm{O}-\mathrm{E}$, varias están en sentido contrario.

Parece probable que las orientaciones deban explicarse en relación con la proximidad a un muro o a una vía, con el estado de la superficie del terreno del área cementerial y de su utilización. La misma explicación cabe para la planificación o no de los enterramientos en general, como se ha dicho en el 
caso de Tarraco: «las variaciones de la orientación debieron ser consecuencia de la adaptación a espacios arquitectónicos — residencias suburbanas y mausoleos-y al trazado de la vía » (Gurt, Macías, 2002, 91).

El estudio de reparticiones topográficas de una necrópolis debería mostrar una estructuración del espacio que podría quizá corresponder a lazos de naturaleza familiar o social. Sin embargo, el aspecto que debían presentar los cementerios nos es un tanto desconocido, sobre todo en el caso de las pequeñas áreas cementeriales que solían formarse alrededor de un monumento funerario. Y, de cualquier modo, parece que debía reinar cierto desorden a la vista de las excavaciones arqueológicas. En consecuencia, el grupo de tumbas de la calle Predicadores se hace particularmente interesante por tratarse posiblemente de una zona funeraria donde se enterró un determinado grupo social, en este caso militar.

\section{Los ajuares fúnebres}

En el caso de las inhumaciones debe entenderse por ajuar en un sentido amplio, aquellos objetos depositados de forma deliberada en el contexto de la sepultura junto al cuerpo muerto, y también aquellas ofrendas aportadas durante el proceso del enterramiento, cuando se excavó la fosa, siendo estas últimas difíciles de reconocer. Las cremaciones pueden aportar otros objetos, como, por ejemplo, el depósito de aquellos que no se habían echado en el rogus (hoguera) y que eran enterrados con las cenizas junto a los que habían servido de pasto a las llamas al lado del cuerpo incinerado. A esto habría que añadir los objetos de material perecedero (madera, tejido y ofrendas alimentarias) que desaparecerían con el fuego.

Siendo el fenómeno de la muerte uno de los más misteriosos para los humanos, no es extraño que haya estado siempre relacionado con creencias religiosas y, por ello, la totalidad de las sociedades conocidas han practicado desde los tiempos más antiguos ceremonias funerarias destinadas a propiciar el viaje a la nueva vida que la muerte representa. En el transcurso de estas ceremonias, los objetos utilizados, la mayoría de las veces de uso cotidiano, adquieren significados rituales, pudiendo tras ellas formar parte del ajuar funerario, es decir, del acompañamiento del cadáver en el momento del sellado de su sepultura. 
Sin embargo, es sabido que la introducción de ofrendas con carácter de ajuar en las tumbas no fue nunca mos romanorum. Es más, en el caso de hallazgos de esta índole habría que buscar la explicación en la posibilidad de que se trate incluso de un uso autóctono, es decir, del resultado de influencias, de perduración de tradiciones entre el rito local y el rito culturalmente romanizador. No obstante, buena prueba de que a veces se infringían las buenas costumbres lo constituye el hecho de que en época de los Severos se dictaran unas medidas prohibiendo precisamente el depósito de objetos de valor en las tumbas (Cuq, 1896).

Seguramente el vasito del enterramiento infantil (Tumba I) sería utilizado como contenedor de algún resto ceremonial tras haber formado parte de las profusiones liquariae, sin embargo, se cometió el error de lavarlo en el momento de su aparición, imposibilitando el análisis de posibles restos de su contenido.

Los depósitos de ofrendas animales son mucho menos frecuentes en las inhumaciones que en las incineraciones, y, además, en estas últimas suelen estar calcinados entre los restos de la cremación. Un excelente ejemplo está constituido por los recipientes cerámicos hallados en el interior del bustum (Inc. I), con evidente prueba de haber sido quemados en la pira, después de haberse roto intencionadamente, como lo demuestra la diferente coloración de los fragmentos de la jarra y el plato (véanse las pp. 152-153).

Estudios realizados sobre depósitos de material fúnebre en época romana han logrado distinguir en algunos casos la diferencia cuantitativa de los hallazgos arqueológicos según se trate de sepulturas de incineración o de inhumación.

En el caso de las cremaciones, Müller $(1977,12-17)$ estableció dos categorías de ofrendas: ofrendas primarias (Primärbeigaben), que son las que arden junto al cadáver en la pira funeraria, y ofrendas secundarias (Sekundärbeigaben), que no se queman y permanecen intactas; ${ }^{81}$ no obstante, estas últimas son muy escasas, y encuentran su explicación en obedecer a una tradi-

$81 \mathrm{Al}$ respecto, cf. también Van Doorselaer (1967), 92-99 y111-112; Castellá (1987), 26. En la necrópolis de Avenches casi el $90 \%$ de las piezas de cerámica habían sufrido el fuego, mientras que en las regiones renanas las ofrendas secundarias son mucho más numerosas (Müller, 1977, 12) tanto en sepulturas con urna como en las que no la tienen, y también en las tumbas tipo bustum. 
ción anterior. Un estudio en profundidad sobre el tema de la presencia de ajuares en las tumbas de incineración se debe recientemente a D. Vaquerizo, J. A. Garriguet y S. Vargas (2005).

Otro aspecto interesante fue planteado por Rebecchi (1991, 149), al cuestionarse si el ajuar fúnebre reflejaba las condiciones materiales y el rango social de los difuntos. Sin embargo, el hecho de que la investigación se base generalmente en una documentación deficitaria no permite concluir un argumento decisivo, ya que, a partir de los simples datos arqueológicos, es muy difícil deducir el vínculo entre la elección del modo de sepultura y la posición económica y social de las gentes, y así el examen del aspecto cuantitativo y cualitativo de las ofrendas podría resultar arbitrario (Bel et al., 1991, 29).

Sin embargo, puesto que como se ha dicho no era costumbre romana la introducción de otros elementos que no fueran el cadáver y algún otro objeto integrante de la propia ceremonia, lo habitual en la excavación de cementerios de finales del siglo II y del siglo III es que buen número de tumbas se encuentre sin ajuar de ningún tipo. Así, en una de las mejores estudiadas que presentan tanto incineraciones como inhumaciones, y tratándose por este motivo de una de las que más fiabilidad pudiera arrojar, la de Saint-Lambert y Pauvadou/Lagon Bleu (Fréjus, Francia), se ha calculado aproximadamente que la cuarta parte de estas carecen absolutamente de ajuar en el más amplio sentido de la palabra; cuando se trataba de cremaciones se recogía solo parte de los restos depositados en la hoguera para arrojarlos a la sepultura, encontrándose los restos de ofrendas funerarias esparcidos alrededor de la urna (Bel et al., 1991, 23). Esto explicaría el hallazgo de fragmentos en el pozo cinerario del bustum de la calle Predicadores. La sobriedad que se documenta en las incineraciones, donde es frecuente que aparezcan estos restos calcinados y dispersos entre los residuos de la cremación, se hace todavía más evidente en las inhumaciones, que se presentan incluso más pobres que aquellas.

Este fenómeno se constata también en el caso de la necrópolis occidental de Caesaraugusta, donde se reconoce mayor complejidad en el caso de las incineraciones. El intento de estimar diferencias o similitudes puede resultar aventurado dado el exiguo número de ejemplares de los que disponemos; no obstante, entre las inhumaciones habría que destacar las dos sepulturas de adultos que fueron enterrados con su vestimenta (caso de las Tumbas VII, VIII con calzado claveteado), (el niño con el vasito, Tumba V; la Tumba IX, de mujer joven con aguja de hueso en la cabeza y anillos; varios con anillos. 
En lo que respecta a las incineraciones, solo se cuenta con la del monumento, con jarra, moneda y plato, entre otros (vid. las pp. 35-39).

Entre los elementos hallados en el contexto de estas tumbas se van a comentar aquellos que son de alguna manera habituales en el mundo funerario romano: la presencia de clavos (de calzado y de ataúd), de cerámica (rota o no intencionadamente) y de monedas. Otras piezas, como el caso de la gran fíbula de plata (Tumba VII), deben considerarse extraordinarios, y, en cierto modo, el caballo/s probablemente decapitado y enterrado en una fosa pueden adquirir un significado especial (véanse las pp. 81-83).

\section{Los clavos de caja de madera}

De entrada, y la rigurosidad de la metodología usada en la excavación de las sepulturas lo avala, la presencia de estos objetos no parece obedecer a un significado ritual como se ha sugerido en otros ejemplos, donde se han hallado dispuestos alrededor de cráneos o de las ofrendas y a los que se les ha atribuido un valor mágico. ${ }^{82}$ En el exterior de las tumbas de incineración de Belo aparecieron numerosos clavos de bronce, a veces son anzuelos, entre las piedras que sujetaban la urna y con la punta dirigida al exterior, hecho al que se ha atribuido un posible significado apotropaico o profiláctico (Remesal, 1979, 41).

Más frecuente es el hallazgo de clavos en las necrópolis de época romana de Ampurias que revelan la presencia de cajas de madera, como sucede en la Incineración Ballesta 3 (Almagro, 1955, 19). Lo mismo ocurre en Tarragona, donde se han excavado inhumaciones con ataúdes de madera, datados en el siglo III (VV. AA., 1987a, 207-208).

Los clavos hallados en el interior de las fosas de inhumación de la calle Predicadores pertenecieron sin duda alguna a los ataúdes en los que se depositaron los cadáveres, y su ubicación se circunscribe a los ángulos preferentemente (véanse las láms. 38, 40, 41, 47, 51, 53, 56, 57). Todas las inhumaciones, excepto las infantiles, conservaban clavos de hierro.

82 Véase Bel et al. (1991), 24. En la necrópolis de Cabasse se encuentra el testimonio de clavos dispuestos alrededor del cráneo de un niño, además de algunas ofrendas, entre las cuales una jarra había sido atravesada por uno de ellos. Clavos agrupados aparecieron en Ampurias (Almagro, 1955, 97: necrópolis Rubert, tumba 14: 28 clavos); El Pradillo (Medellín, Badajoz), clavos agrupados en las tumbas 5, 6 y 8 (Del Amo, 1973, 60, descarta que sean de ataúd). 


\section{Clavos de calzado}

Estos elementos se han venido localizando cada vez más en la medida en que la metodología de excavación en las necrópolis de ciudades se hacía más rigurosa, y un buen ejemplo de ello lo constituyen los estudios del Londres romano (Rhodes, 1980, pássim; Whytehead, 1986, 96, fig. 42; Barber, Bowsher, 2000, 196, p.e.) y de algunos cementerios galorromanos, como el de Saint-Paul-Trois-Châteaux, necrópolis en la que predomina la incineración. En esta última, una inhumación contenía dos suelas de calzado claveteadas, una colocada entre los dos fémures y otra a la altura de los pies. También aquí está atestiguado el depósito de calzado en las incineraciones entre los residuos de la cremación; en este caso, no puede saberse si se trataba simplemente de un elemento de vestido o de un depósito, como sucede a veces también en el caso de las inhumaciones (Bel et al., 1991, 25).

En el caso de los restos de calzado hallados en las inhumaciones de Zaragoza, no hay duda de que los cadáveres de las Tumbas VII y VIII estaban calzados cuando fueron inhumados, dada la ubicación de los clavos mezclados con los huesos de los pies y la presencia de restos de cuero en la misma situación (véanse las láms. 47, 51, 56, 96).

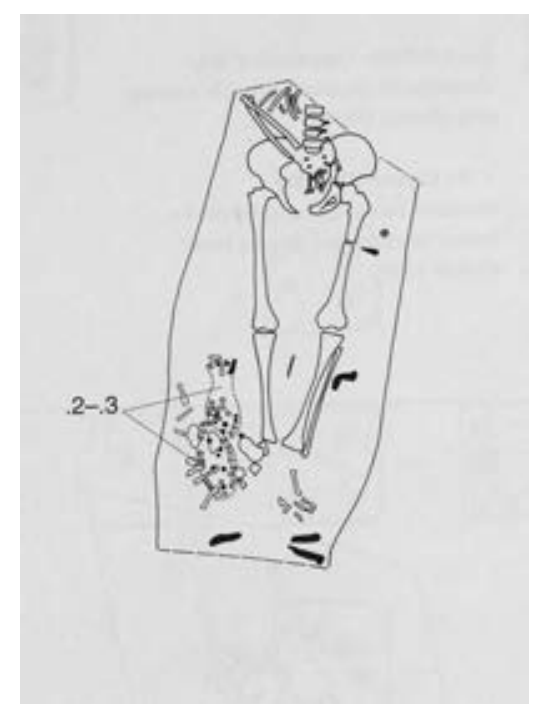

95. Calzado en el cementerio oriental de Londres (Barber, Bowsher, 2000, 196). 


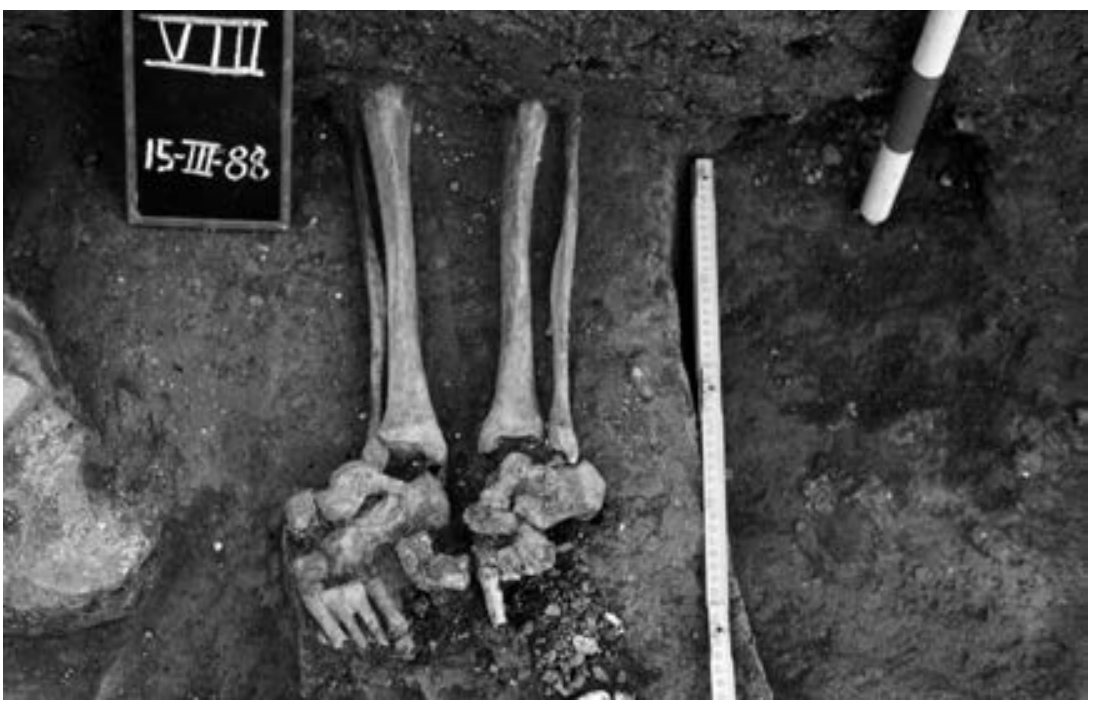

96. Restos de clavos en la zona de los pies. Tumba VIII.

\section{Las ofrendas de cerámica}

Generalmente, el ajuar funerario romano estaba constituido por vajilla de mesa, siendo escasa la diversidad de las formas cerámicas: platos, copitas, jarras y cuencos se cuentan entre los más frecuentes, a veces alguna lucerna y, generalmente, una moneda. También se aprecia que el repertorio de las formas cerámicas presentes en las inhumaciones es más reducido que en las incineraciones. Es frecuente, por ejemplo, que en cada tumba galorromana de incineración, además de la urna cineraria, hubiese una jarra para la bebida, un plato o una escudilla y una moneda (Van de Weerd, 1965, 118). Sin embargo, Van Doorselaer ${ }^{83}$ no es partidario de que esto sea considerado una norma general; no obstante, constituyen hoy por hoy los hallazgos más tradiciona-

83 Van Doorselaer (1967), 101. Los numerosos tipos de cerámicas empleadas como urnas parecen probar que no existía forma característica destinada especialmente a este uso. Por el contrario, se recurre a la cerámica de uso cotidiano: cacerolas, jarras, etcétera. 
les. Este hecho ha sido constatado también en algunas sepulturas de la calle Predicadores como se ha visto. ${ }^{84}$

Entre los principales recipientes empleados durante los sacrificios figuran la jarra para el agua lustral o el oinokoe para el vino y la patera para las libaciones (Baradez, 1967, 7-47; 1968, 77-93; De Laet et al., 1972, 25). En Fréjus las jarras representan entre un 20 y un $40 \%$, correspondiendo los porcentajes más altos a las incineraciones (De Laet et al., 1972, 25).

La jarra y la pátera aparecen con frecuencia también en representaciones en relieve a los lados de las aras (Cagnat y Chapot, 1917-1920, I, 174, II, 56).

Otros objetos rituales como los balsamarios de vidrio suelen ser más habituales en las incineraciones, haciéndose más raros a partir de la segunda mitad del siglo I y desapareciendo totalmente a finales del siglo II en las tumbas de inhumación. Sería la explicación de su ausencia en la Necrópolis Occidental.

Se ha apuntado que en algunas necrópolis hay tipos de ofrendas que no se asocian nunca, como las jarras en cerámica común y balsamarios del mismo material. ${ }^{85}$

\section{Urnas cinerarias}

Mención aparte la constituyen los envases para guardar las cenizas de las incineraciones. A pesar de que en algunas necrópolis han podido obtenerse diferencias de orden cronológico en el material de las urnas, ${ }^{86}$ el utilizado con más frecuencia en los primeros siglos del Imperio es la cerámica. Suelen ser ollas de cerámica reductora de color gris, utilizándose también jarras y, en

84 Para materiales empleados en ajuares funerarios entre finales del siglo I el siglo II, véase Vaquerizo et al. (2005), en especial las pp. 169-176.

85 Bel et al. (1991), 23. Estas diferencias son atribuidas en parte a una evolución cronológica en la elección de las ofrendas, si bien indican la provisionalidad de esta hipótesis dado el estado preliminar en que se encuentra el estudio.

86 A partir de las excavaciones en Belo, Remesal (1979) llegó a la conclusión de que en época de Tiberio se empleaban solo urnas de cerámicas, en la de Claudio se imponen las cajas de piedra y durante el periodo de Nerón y de los Flavios van siendo reemplazados por urnas de vidrio en las sepulturas ricas. Para un estado actual de este tema en el Alto Imperio ha de verse el estudio de Vaquerizo et al. (2005), 170-176. 
menor medida, fondos de recipientes (Castellá, 1987, 14, n. 80). Las cenizas de las Incineraciones I y II de Predicadores se introdujeron las de la primera en una olla y las de la segunda en una jarra.

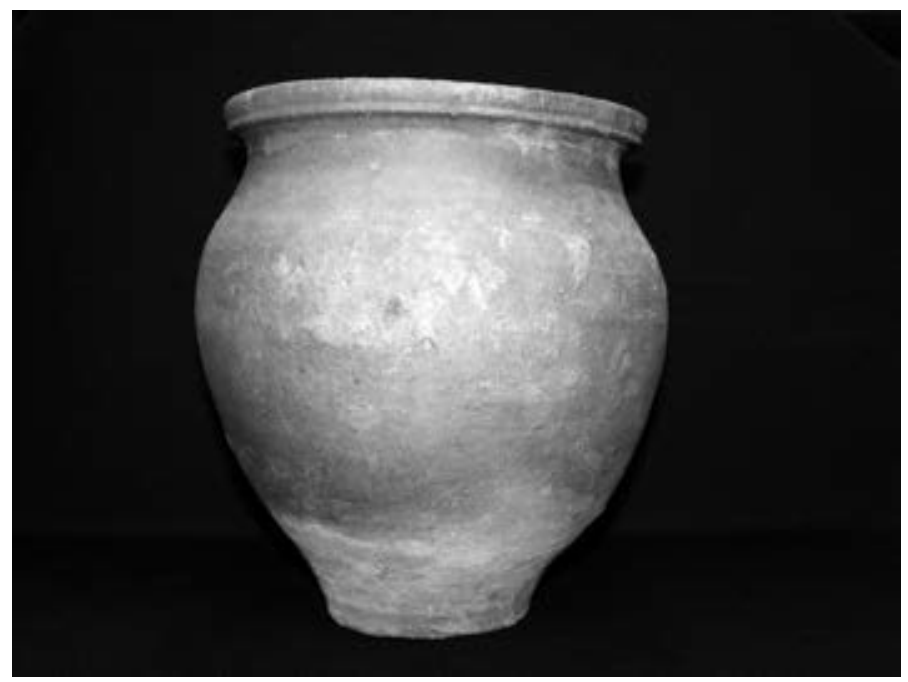

97. Olla que contenía las cenizas del monumento funerario.

Un elemento con reconocida función apotropaica está constituido por la lucerna, cuya introducción en las tumbas aparece desde el siglo I de la era en los dos ritos por igual, siendo a finales del siglo I y sobre todo durante el siglo II cuando esta práctica se amplifica con una preponderancia de Firmalampe en las inhumaciones bajo tejas. En el caso de la necrópolis de Predicadores no pudo asociarse ningún ejemplar directamente.

\section{Las cerámicas rotas intencionadamente}

$\mathrm{Al}$ tratar del contexto fúnebre hallado junto a la urna cineraria del bustum, se ha hecho ya referencia a unas vasijas, dos en concreto, cuyos fragmentos presentan una coloración diferente. Se trata de una jarra de gran tamaño y de un plato cuyas paredes, tras su restauración, ofrecen un aspecto de puzle por su diferente coloración causada por la acción del fuego. 
$\mathrm{Al}$ parecer, este fenómeno suele documentarse en las incineraciones. Incluso se ha llegado a hablar del «sacrificio funerario de la cerámica » (Castellá, 1987,14, n. 80), consistente en romper la vajilla utilizada en las exequias de manera intencionada. Este ritual, que tenía probablemente un significado simbólico, podía tener lugar bien sobre la pira funeraria o en las proximidades. Ello explicaría la diferente coloración de los fragmentos según el grado de calor que sufrieran junto a la pira y el hecho de que, aunque se hayan multiplicado al estallar, sean encontrados de nuevo en el interior de la sepultura, tras haber sido recogidos por los familiares y asistentes o por los encargados de la ceremonia.

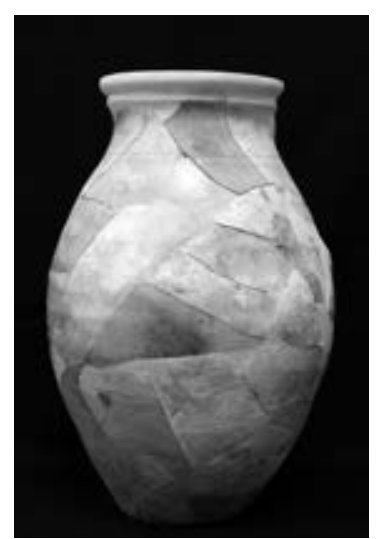

98. Jarra para el agua lustral, hallada en el interior del bustum. Obsérvese la diferente coloración de sus fragmentos.

Del mismo modo, la ruptura ritual de las cerámicas podría igualmente explicar por qué en algunas tumbas intactas se han encontrado fragmentos de vasos rotos e incompletos. Es lógico que se trate de tumbas de incineración, y la circunstancia pueda explicarse por una defectuosa recogida. En el bustum se hallaron vasijas rotas pero completas junto a otras incompletas.

$\mathrm{El}$ origen de este ritual funerario romano parece proceder de un rito prerromano itálico (La Rocca, 1984, 115). No obstante, se ha puesto de manifiesto tambien en diversas partes del Imperio como África (Baradez, 
1957, 225), Galia (Van Doorselaer, 1967, 115), ${ }^{87}$ y en necrópolis hispánicas como Carmona (Belén, 1983, 222). El carácter profiláctico de este fenómeno parece fuera de dudas.

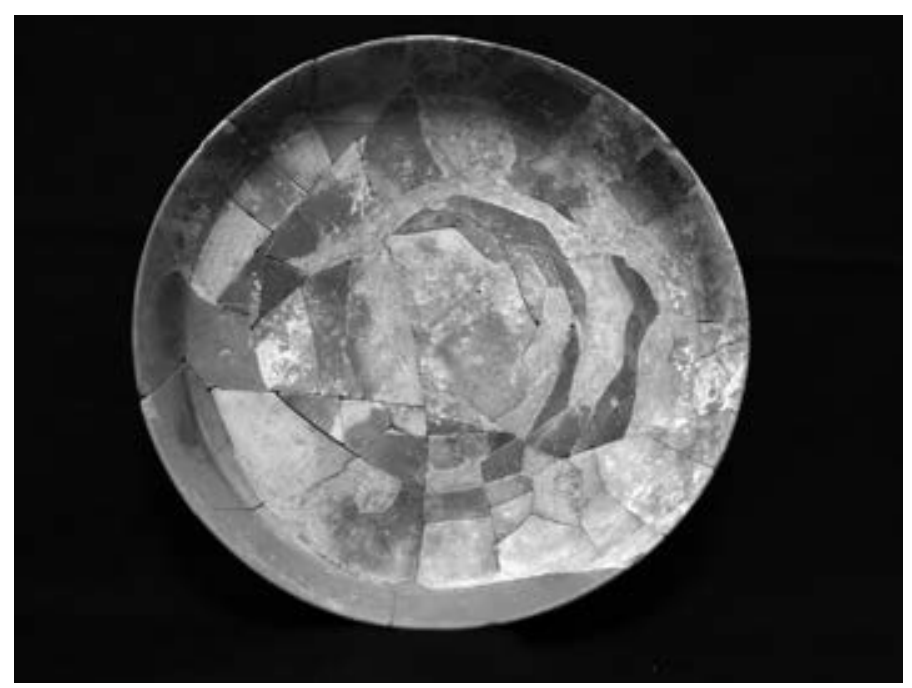

99. Incineración I (bustum). Plato hallado en el interior del monumento en el que se aprecia la diferente repercusión del fuego en sus fragmentos, siendo el color original el anaranjado de la zona inferior del plato.

\section{Monedas}

En cuanto a la presencia de monedas introducidas como ofrendas, hay que tener en cuenta que su hallazgo puede estar empañado de cierta ambigüedad. En primer lugar, habría que diferenciar la circunstancia de la introducción de la moneda. La acción del fuego desplazaría la moneda del cadáver, sufriendo también alteración del fuego y siendo objeto de selección entre los restos de ofrendas. Es el caso de la incineración de la edícula, cuya moneda quedó en su interior. Las monedas que no tienen huellas de fuego habrían sido introducidas tras la cremación con las cenizas. Si la tumba está

87 Cita ejemplos: un plato de $t$. s. en 19 fragmentos, algunos quemados, otros no (para él, el rito es prerromano); se trata de platos pequeños que tendrían carácter votivo. 
alterada, se hace difícil identificar la pieza en el mismo contexto, ya que puede tratarse de un material aportado para cubrir el enterramiento, y no de la pieza ofrecida al barquero Caronte. ${ }^{88}$ Por otro lado, la moneda halla$\mathrm{da}$ en el interior de una sepultura intacta, aporta un terminus post quem para el enterramiento, pero no puede proporcionar una fecha precisa ante la posibilidad de dilatación del periodo de su utilización; a esto se añade el hecho de que las monedas ofrendadas generalmente suelen ser piezas desgastadas, deterioradas o calcinadas. Las piezas que pueden relacionarse con las tumbas ya citadas son una moneda de bronce de la dinastía antonina en el interior del bustum, una de Filipo el Árabe en la Tumba IV y una de Claudio II en la Tumba VIII. Otras monedas se hallaron también, pero en estado ilegible. ${ }^{89}$

\section{Las tumbas de bebés y niños}

Entre el grupo de Predicadores se inhumaron un neonato y un feto, y en ambas tumbas se pudo detectar la delicadeza de la operación. De la misma manera, había una tercera tumba con un niño de 2 a 4 años al que se enterró con un vasito. Se trata de una demostración más de que en el ritual funerario romano los enterramientos infantiles ocupan un lugar muy especial; en cambio, un bebé de menos de cuarenta días podía incluso ser enterrado bajo la casa familiar, ya que a estos niños no se les incineraba, según los testimonios de Juvenal y de Plinio el Viejo, principalmente. Si bien la norma estaba constituida por sus primeros cuarenta días, parece que desde muy temprano llegaron a confundirse los bebés de esta edad con otra categoría de niños: los que todavía no tenían su primer diente (Néraudau, 1987).

Plinio (Hist. Nat., 7.72) recoge la costumbre romana de que los niños muertos antes de salirles los dientes no eran incinerados y que solo los dien-

88 La introducción de una moneda en la boca (aunque es frecuente que se encuentren en la zona del tronco o incluso en la parte inferior si es una inhumación) es una tradición helena que las clases populares romanas adoptaron fielmente (Cuq, 1896, 1388-1389).

89 En el nivel que cubría las tumbas se hallaron las monedas de los siguientes: Claudio, Nerón, Domiciano, Trajano, Valeriano (3), Galieno (5), Salonina, Claudio II (3), Constantino (3), Decencio, Constancio II (2), Valente y Graciano. Son más los ejemplares, pero no fue posible su lectura por su deficiente conservación. A estas hay que añadir las citadas que formaban el contenido de la bolsita de cuero (p. 86). 
tes resisten a la incineración ${ }^{90}$ (véase también Juvenal, Sat., XV, 131: cum funus adultae virginis occurrit vel terra clauditur infans et minor igne rogi). Y Plutarco que enterrados según un ritual diferente del reservado a los adultos (Moralia, 45, 608a-612b). Los bebés difuntos no tenían derecho ni a la libatio, ni a otras ceremonias reservadas a los demás. Sin embargo, una vez que el niño tiene dientes accede a la categoría de los que, como los adultos, son incinerados o inhumados: a esta categoría pertenecía la inhumación de la Tumba I.

Finalmente, las conclusiones que se realizan referentes a la transición entre los dos ritos no pueden aplicarse a las sepulturas de niños. Sin duda, los estudios antropológicos y arqueológicos que se realicen a partir de ahora, permitirán conocer con mayor precisión a partir de qué edad y en qué época se inhuma o se incinera a los niños, si bien la nota general es que la media de edad de los inhumados es más baja que la de los incinerados (Bendala, 1991, 82 y $84-86$ ).

Fabio Planciades Fulgencio (Expositio sermonum antiquorum, 7, Opera) se refiere a que los antiguos llamaban subgrundaria (tejadillo; también entendido porque podían enterrarse bajo el de la puerta que daba al patio [sub grundo]) a las tumbas de niños que no habían llegado a los cuarenta días de vida, ya que en ausencia de huesos no podían quemarse y, por otra parte, la masa del cadáver no era suficiente para formar un montículo, por lo que debía protegérseles con una estructura superior que a su vez les daba cobijo (Tumba VI, entre tejas).

Finalmente, recogemos una cita de Juvenal, Sátiras, XV, 139-140, que hace referencia al tema de los enterramientos infantiles: « $[\ldots]$ terra clauditur infans / et minor igne rogi $[. ..] \gg$ ([...] la tierra se cierra sobre un niño pequeno / demasiado joven todavia para la hoguera [...]).

El niño, el recién nacido y el feto, que fueron enterrados cuidadosamente entre los militares, habrían sido posiblemente consecuencia de embarazos de las mujeres que formaban parte del séquito que acompañaba a estos hombres, lejos de sus lugares de procedencia.

90 Si un bebé sin dientes era incinerado era probable que no quedara nada de su cuerpo para reintegrarse a la tierra, con lo cual el rito quedaba inacabado. 


\section{CONCLUSIÓN}

Sirvan estas últimas líneas para reiterar algunas consideraciones sobre el resultado del trabajo. En ellas voy a tratar de exponer la idea fundamental obtenida tras largos periodos de abandono y retorno a este estudio. He de confesar que, si bien la impresión de considerar la mayor parte de estas tumbas como un conjunto funerario perteneciente a un grupo militar estuvo latente desde casi el principio, el hecho determinante para esta hipótesis ha sido el resultado del estudio antropológico que ha servido de apoyo y aclaración, a pesar de los puntos oscuros que todavía persisten.

Si la excavación con una metodología apropiada de las áreas cementeriales es necesaria para conocer el panorama funerario y tratar de reconstruir el funcionamiento de estos lugares periurbanos, desafortunadamente, el dinamismo de ciudades milenarias como Zaragoza obra en contra de estudios sistemáticos, debiendo la investigación conformarse con los pequeños retazos conservados bajo las cimentaciones de edificios y que así han podido llegar a nosotros.

De ningún modo puede afirmarse que en las proximidades de la Puerta Occidental de la muralla romana hubiera una gran necrópolis. En primer lugar, los hallazgos son escasos: no llegan a la veintena en los tres solares afectados; no obstante, resulta curioso que no se hayan encontrado sepulturas evidentes en la excavación de los solares próximos.

El mausoleo y las tumbas presentan en la planimetría la ortogonalidad propia de la planta de la colonia, de la cual son testimonio también los muros de la domus anterior, ordenada respecto a la vía decumana, cuyo trazado seguía en línea recta a lo largo de esta primera manzana de la calle Predicadores. Desde comienzos de la fundación de la colonia las orillas de esta calzada 
debieron acoger monumentos a los que se irían sumando otros; y algunos espacios tras ellos irían ocupándose también sucesivamente. A este último hecho debe de atribuirse el hallazgo de las tumbas de la calle Predicadores.

La adscripción tipológica del pequeño edificio funerario corresponde al bustum con aedicula. Era una sepultura abovedada, recubierta de una gruesa capa de mortero, enlucido y pintado de rojo, que participaría de la idea del «sepulcro-casa». Podría situarse a finales del siglo II por la moneda de la dinastía Antonina que apareció quemada en su interior (el asesinato del último emperador antonino, Cómodo, tuvo lugar en el 192) o en una fecha no muy lejana que pudo tratarse de principios del siglo III. En este último caso habría que situar su inicio con el de la dinastía Severa, que ocupa la primera parte de esta problemática centuria (193-235). El propio Septimio Severo estuvo acantonado con sus legiones en Panonia, región que ya ha sido mencionada en este trabajo por otros motivos. Las dos características más sobresalientes, la aedicula en bóveda de medio cañón y la perforación del enterramiento a través del tubo libatorio, forman parte de una misma corriente funeraria ligada a la costa mediterránea y, en particular, italiana y africana, que se adopta algo después, precisamente en la época de este hallazgo, en regiones orientales europeas.

Y no sería extraño que la situación privilegiada de la colonia Caesaraugusta hubiera propiciado la llegada de costumbres particulares y con ellas la de tipos de tumbas importados. De ahí que las intensas relaciones comerciales, sobradamente puestas de manifiesto en las numerosas excavaciones del Centro Histórico de Zaragoza, las políticas, casi desconocidas, y las culturales, entre las que sobresalen las costumbres, los ritos y, en general, todo aquello que conforma el ser humano, se transmitieran también a las formas de las tumbas inspiradas en los mismos prototipos y, además, profundamente romanas. Razones que ya se han apuntado parecen sugerir que este pequeño monumento fuera el núcleo aglutinante junto al que se fueron añadiendo otras tumbas, en este caso de inhumación. Se advierte en el conjunto funerario cierto orden en su disposición que, junto a semejanzas tipológicas, apoya esta hipótesis. Y nada impide la probable relación de algunos detalles como la fíbula, el caballo sacrificado, con el mundo militar.

El resultado del estudio antropológico ha sido de suma importancia a la hora de extraer conclusiones relativas a la idiosincrasia del grupo funerario. Las inhumaciones forman un grupo cuya filiación desconocemos: seis hom- 
bres jóvenes, una mujer anciana, dos adultas, un niño de 2 a 4 años, un neonato y un feto. Como ya se ha expuesto, características comunes son la situación estratigráfica, una tipología muy similar a todas excepto a las de los recién nacidos; pero en particular sobresalen las características antropológicas apreciadas en los varones.

Así, su carácter militar parece suficientemente justificado por lo siguiente:

- Los varones constituyen el conjunto primordial: 6 de 13 individuos entre los que se cuentan 3 mujeres y 3 bebés.

- Todos los varones pertenecen a una edad juvenil o adulta temprana.

- Todos presentan parecidas anomalías en su esqueleto, que son fruto de una actividad física importante, como era el caso de los componentes de las tropas romanas, que aun en periodo de paz sufrían duros adiestramientos de todo tipo.

- Las patologías dentales informan también acerca de la dieta acostumbrada que conocemos por los textos escritos, que producía por su dureza un gran desgaste en individuos jóvenes. A ello hay que añadir las conclusiones del análisis antropológico que relaciona este hecho también con situaciones de estrés causantes de bruxismo.

La disposición de las Tumbas VII y VIII es gemela: la profundidad de las fosas, su proximidad (separadas solamente por un pequeño tabique) e incluso la similitud que presentaba el atuendo personal (caligae) de los individuos allí enterrados era muy similar. Es probable, e imposible de detectar por su arrasamiento, que ambas inhumaciones fueran coetáneas e incluso que las cubriera un mismo monumento funerario.

Pero ¿qué significa un conjunto de soldados que van siendo sepultados en una zona muy próxima a la muralla de la ciudad? ¿Se trataba simplemente de un destacamento militar de vigilancia? Desafortunadamente, la arqueología nos ha ofrecido el efecto solamente, la causa queda por desvelar. Pero aun así, la explicación histórica está en franca desventaja con los datos desvelados por la excavación: en Caesaraugusta hubo destinado un grupo de personas pertenecientes al mundo militar, posiblemente del este de Europa, entre los que se encontraban también mujeres que trabajaron duro, como testimonian sus huesos, y niños. 
A la perduración de esta zona como cementerio se ha aludido ya en páginas anteriores. Sabemos que prosigue esta función tras el siglo III ininterrumpidamente por la presencia de tumbas tardoantiguas cercenadas en época islámica. Actualmente conocemos la relevancia del suburbio occidental, en el que se incluye la zona de la c/ Predicadores como se ha dicho, a través del hallazgo paleocristiano muy próximo: el dato que proporciona la excavación de la calle Dosset es la ubicación de un conjunto funerario religioso situado hacia el sur y que ya no está en la vía funeraria. $\mathrm{Y}$ al respecto, este hecho es lo habitual con el advenimiento del cristianismo, momento en el que las necrópolis se organizan en torno a los edificios de culto, basílicas y martiria, lugares de enterramiento de mártires o de su memoria cristianizada (Galve et al. 2005).

Pero no acaba aquí la función cementerial. Las gentes de esta ciudad continuarán enterrando aquí a sus muertos hasta muy entrada la era medieval. La fundación de la maqbarah Bal-al-Tuylatula debió producirse ya en la época inmediata a la llegada de los árabes a la ciudad de Zaragoza. Su ubicación a las puertas y el encontrarse con esta zona funeraria en activo desde época romana estaba plenamente justificada. El final del cementerio musulmán constituye la interrupción de una costumbre milenaria en esta parte de la ciudad (Galve, 1991, 1995, en prensa), con la conquista cristiana (1118), iniciándose pronto la vida activa de un barrio comercial, el de la Población del Rey, al que se trasladó el mercado. 


\section{BIBLIOGRAFÍA}

ADAM, J. P. (1984), La construction romaine, materiaux et techniques, París.

Adriani, A. (1936), «La nécropole de Moustafa Pacha», Annuaire du Musée grécoromain, 1933/34-1934/35, p. 96, Alejandría.

Aguarod, M. ${ }^{a}$ C. (1991a), «La necrópolis oriental», en M. Beltrán, «Caesaraugusta», en E. Adiego (ed.), Las necrópolis de Zaragoza, Cuadernos de Zarago$z a, 63$, Zaragoza, pp. 23-26.

- (1991b), «Ficha Catalográfica n. ${ }^{\circ} 22 »$, en VV.AA, Arqueología de Zaragoza: 100 Imágenes Representativas, Zaragoza.

- (1991c), Cerámica romana importada de cocina en la Tarraconense, Zaragoza.

- y A. Mostalac (1997), La Arqueología de Zaragoza en la Antigüedad tardia, en Historia de Zaragoza, 4, Zaragoza.

Allain, J., I. Fauduet y M. Tuffreau-Libre (1992), La nécropole Gallo-romaine du Champs de l'Image à Argentomagus (Saint-Marcel, Indre).

Almagro, M. (1953), Las necrópolis de Ampurias, I. Monografias Ampuritanas, Barcelona.

- (1955), Las necrópolis de Ampurias. Monografias Ampuritanas, II, Barcelona.

- (1975), La necrópolis hispano-visigoda de Segóbriga. Excavaciones Arqueológicas en España, 84, Madrid.

- (1977), «La necrópolis romana de las parcelas 45 y 46 de Segóbriga (Saelices, Cuenca), Campaña de 1975-1976», Noticiario Arqueológico Hispánico, 7, pp. 213-246.

Almagro Gorbea, M. (1962), «Nuevas tumbas halladas en la necrópolis de Ampurias», Ampurias, XXIV, pp. 225-238.

Álvarez, J. M. (1943), «Nuevas sepulturas romanas en Mérida », Memorias de los Museos Arqueológicos Provinciales, 4, pp. 48-52.

Amo, M. del (1973), «Estudio preliminar sobre la romanización en el término de Medellín (Badajoz). La necrópolis de El Pradillo y otras villas romanas $\gg$, Noticiario Arqueológico Hispánico, 2, pp. 55-88. 
ANDREAE, B. (1968-1969), «Imitazione ed originalità nei sarcofagi romani», Atti della Pontificia Accademia romana di Archeologia S. II, Rendiconti, XLI, pp. 145-166.

ARANEgui, C. (1995), «Los monumentos funerarios romanos descubiertos en Edeta (Llíria, Valencia)», pp. 197-210.

- (1996), Els romans a les terres valencianes, Valencia.

Arbeloa, J. V. M. (1993), «Carrer de Robert Aguiló, 38, Tarragona», Anuari d'intervencions arqueologicas, 254.

- (1995), «L'arqueologia de la mort a l'Alt Imperi: el suburbi oriental de Tàrraco», Citerior 1. L'Arqueologia de la mort. El món funerari a l'antiguitat a la Catalunya Meridional, Tarragona, pp. 119-138.

ARCE, J. (1979a), Caesaraugusta, ciudad romana, Zaragoza (Colección Básica Aragonesa, 9).

- (1979b), «Nota sobre el rito de incineración de las tumbas de Castulo», en Castulo II. Excavaciones Arqueológicas en España, 105, pp. 405-406.

- (1988), Funus Imperatorum, Madrid (Alianza Forma, n. ${ }^{\circ} 68$ ).

Audin, A. (1960), «Inhumation et incinération», Latomus, XIX, pp. 312-322 y 518-532.

AuteXier, J. Y., S. Moret y J. L. Roche (1984), «La nécropole de Louroux (Creuse)», Révue Archéologie du Centre de la France, XVII, fasc. 1-2, 1978, pp. 51-67, 11, Roma.

BACHIELLI, L. (1986), «Monumenti funerari a forma di cupula: origine e diffusione in Italia meridionale», en L'Africa romana. Atti del III Convegno di studio. Sassari, 13-15 diciembre 1985 (Sassari, 1986), pp. 303-319.

BAENA, L. (1993), «Monumentos funerarios romanos de Segobriga», en Estudios a A. Balil in memoriam, Málaga, pp. 147-161.

BAILEY, D. M. (1980), A Catalogue of the Lamps in the British Museum II. Roman Lamps made in Italy, Londres.

BaldasarRe, I. (1987), «La necropoli dell'Isola Sacra (Porto)», en H. von Hesberg y P. Zanker, Römische Gräberstrassen. Seldbsdarstellung-Status-Standard, Múnich, pp. 125-138.

- (2002), «La necropoli dell' Isola Sacra», en D. Vaquerizo (ed.), Espacios y usos funerarios en el Occidente romano, vol. I, Córdoba, pp. 11-26.

BALIL, A. (1983), Lucernas de la necrópolis romana de Palencia. Publicaciones de la Institución Tello Téllez de Meneses, 48.

BARADEZ, J. (1957), «Nouvelles fouilles à Tipasa. Survivances du culte de Baal et Tanit au I siècle de l'ère chrétienne. 1er partie. Tombe d'un sacrificateur», Lybica, v, pp. 159-294.

- (1967), «Nouvelles fouilles á Tipasa: Nécropole païenne occidental, sous la maison des fresques», Lybica, IX, pp. 7-47. 
BARAdEZ, J. (1968), «Les nécropoles de Tipasa: tombes du cimetière occidental cotier», Antiquités Africaines, 2, pp. 77-93.

Barandiarán, I. (1973), Guipúzcoa en la Edad Antigua. Protohistoria y Romanización, Zarauz, pp. 85-91.

BARBER, B., y D. BOwSHER (2000), The Eastern Cementery of Roman London. Excavations 1983-1990, Londres.

BARBET, A. (2002), «La peinture funéraire romaine en Occident, premier inventaire», en D. Vaquerizo (ed.), Espacios y usos funerarios en el Occidente romano, vol. I, Córdoba, pp. 57-80.

Bayard, D., y J. L. MASSY (1983), Amiens Romain. Samarobriva ambianorum. Amiens.

BAYET, J. (1984), La religión romana. Historia política y psicológica, Madrid.

BeAL, J. C. (1983), Catalogue des objets de tabletterie du Musée de la Civilisation Gallo-romain de Lyon.

Bel, V., L. Tranoy, I. Beraud y Ch. Gebara (1991), «Les nécropoles à incinérations et à inhumations en Gaule Méridionale», en M. Vidal (coord.), Incinérations et inhumations dans l'Occident romain aux trois premiers siècles de notre ére, Actes du Colloque International de Toulouse-Montréjeau (IV Congrès Archéologique de Gaule Méridionale), 7-10 octobre 1987, pp. 9-40.

BELÉN, M. (1983), «Aportaciones al conocimiento de los rituales funerarios en la necrópolis romana de Carmona (Sevilla)», en Homenaje al Prof. Martín Almagro Basch, III, pp. 209-226.

- S. Gil de los Reyes, G. Hernández, R. Lineros y M. Puya (1986), «Rituals funeraris a la necrópolis romana de Carmona (Sevilla)», Cota Zero, 2, pp. 56-61.

Beltrán, J. (1990), «Mausoleos romanos en forma de altar del sur de la Península Ibérica», Archivo Español de Arqueología, 63, pp. 183-226.

Beltrán de Heredia, J. (2007), «La Via Sepulcralis de la plaza de la Villa de Madrid. Un ejemplo del ritual funerario durante el Alto Imperio en la necrópolis occidental de Barcino», Quaderns d'Arqueologia i Història de la ciutat de Barcelona, 3, pp. 12-63.

BELTRÁN, M. (1976-1978), «Enterramientos infantiles en el poblado ibérico de la Romana (La Puebla de Híjar, Teruel)», Simposio Internacional Els origens del mon ibèric, Ampurias, 38-40, pp. 307-315.

- (1982), La Arqueología de Zaragoza. Últimas investigaciones, Zaragoza.

- (1991), «Caesaraugusta», en E. Adiego (ed.), Las necrópolis de Zaragoza, Zaragoza, pp. 19-47.

- J. J. Sánchez, M. ${ }^{a}$ C. Aguarod y A. Mostalac (1980), Caesaraugusta I (campaña 1975-1976). Excavaciones Arqueológicas en España, 109, Madrid. 
Beltrán, M., y G. Fatás (1998), César Augusta, ciudad romana. Historia de Zaragoza, n. ${ }^{\circ}$ 2, Zaragoza.

Ben Khader (2000), Mosaici del Museo del Bardo, Túnez.

Bendala, M. (1976), «Las necrópolis de Mérida», en Augusta Emerita, Actas del Simposio Internacional Conmemorativo del Bimilenario de Mérida, pp. 141161, Madrid.

- (1991), «Incinèrations et inhumations dans l'Occident romain au trois premières siècles de nôtre ère: le Sud de l'Espagne», en M. Vidal (coord.), Incinérations et inhumations dans l'Occident romain aux trois premiers siècles de notre ère, Actes du Colloque International de Toulouse-Montréjeau (IV ${ }^{\mathrm{e}}$ Congrès Archéologique de Gaule Méridionale), 7-10 octobre 1987, pp. 77-90.

- (1994), «La ciudad en la Hispania romana», en La ciudad en la Hispania romana, Tarragona, pp. 115-124.

- (2004), «Arquitectura funeraria», en X. Duprè (ed.), Mérida. Colonia Augusta Emerita. Las capitales provinciales de Hispania, 2, Roma, pp. 85-100.

Benoit, F. (1956), «Sépulture-maison à la Madrague de Saint-Cyr-sur-Mer», Rivista di Studi Liguri, XXII, 24, pp. 221-225.

BerciU, I., y W. WOlSKI (1970), «Un nouveau type de tombe mis au jour à Apulum et le problème des sarcophages à voute de l'Empire romain», Latomus, XXIX, pp. 919-965.

Blázquez, J. M. (1975), Castulo, I, Acta Arqueológica Hispánica, 8, Madrid.

- (1976), «Hispania desde el año 139-235», Hispania, 132, pp. 5-87.

- (1978), Historia económica de la Hispania romana, Madrid.

Bonneville, J. P. (1981), «Les cupae de Barcelone: les origines du type monumental», Mélanges de la Casa de Velázquez, 17, pp. 5-38.

- (1984), «Le support monumental des inscriptions: terminologie et analyse», Epigraphie Hispanique, Problèmes de Méthode et de Édition, París.

Bost, J. P., y L. MAURIN (1991), «Incinération et inhumation entre la Loire et les Pyrenées», en M. Vidal (coord.), Incinérations et inhumations dans l'Occident romain aux trois premiers siècles de notre ère, Actes du Colloque International de Toulouse-Montréjeau (IV ${ }^{\mathrm{e}}$ Congrès Archéologique de Gaule méridionale), 7-10 octobre 1987, pp. 41-65.

Bouchenaki, M. (1975), Fouilles de la nécropole occidentale de Tipasa (1968-1972), Argel.

Caballos, A. (1994), «Varia funeraria italicense», Habis, 25, pp. 225-245.

Cagnat, R., y V. СНАРОт (1917-1920), Manuel d'archaéologie romaine, París.

Calza, G. (1940), La necropoli del porto di Roma nell'Isola Sacra, Roma.

CANCELA, M. L. (2002), «Aspectos monumentales del mundo funerario hispano», en D. Vaquerizo (ed.), Espacios y usos funerarios en el Occidente romano, Córdoba, pp. 163-180. 
CANCEla, M. L. (2006), «Los monumentos funerarios hispanos», en J. C. Moretti y D. Tardy (eds.), L'Architecture funéraire monumentale. La Gaule dans l'Empire Romain, Actas del Coloquio Henri-Prades (Lattes, 11-13, octubre, 2001), pp. 205-219.

Canto, A. M., y J. J. Urruela (1979), «Necrópolis del Cerrillo de los Gordos», Castulo II, en J. M. Blázquez (dir.), Excavaciones Arqueológicas en España, 105, pp. 321-346.

CASABONA, J. F. (1991), ficha n. ${ }^{\circ}$ 27, en el Catálogo Arqueología de Zaragoza: 100 imágenes representativas, Zaragoza.

- y J. A. Pérez CASAS (1991), «El Forum de Caesaraugusta», en VV. AA., Zaragoza. Prehistoria y Arqueología, pp. 17-26.

CASAL, R. (1979), «Algunos entalles de la Colección Blanco Cicerón», en XV Congreso Arqueológico Nacional (Zaragoza, 1977), p. 1107.

- (1990), Colección de Glíptica del Museo Arqueológico Nacional (Serie de entalles romanos), I, Madrid, Ministerio de Cultura.

Castellá, D. (1987), La nécropole du Port d'Avenches. Aventicum, IV, Avenches.

Castilla, E., J. De Haro y M. A. López (2004), «El solar n. ${ }^{\circ} 25-27$ de la calle Vázquez López en la Zona Arqueológica de Huelva. La necrópolis sur de ONVBA», Anuario Arqueológico de Andalucíal (2001), vol. III-1, pp. 503-511. Sevilla.

Chevalier, R. (1983), La romanisation de la Celtique du Po. Essai d' histoire provinciale, Roma.

Cid, C. (1949), «El sepulcro de torre mediterráneo y sus relaciones con la tipología monumental», Ampurias, XI, pp. 91-126.

Clarke, G. N. (1979), Winchester Studies, Londres.

- (1979b), The Roman Cemetery at Lanskhills, Oxford.

Conrelli, F., y Y. Thebert (1988), «Architecture funéraire et pouvoir: réflexions sur l'hellénisme numide», Mélanges de l'École Française à Rome, 100, pp. 761-818.

Colominas, L. (2007), «Animals i ideologia en l'àmbit funerari: estudi arqueozoòlogic de la necròpolis de la Plaça de la Vila de Madrid (Barcelona)», Quaderns d'Arqueologia i História de la ciutat de Barcelona, 3, pp. 82-101.

Cumont, F. (1949), Lux Perpetua, París.

- (1959), After Life in Roman Paganism, Nueva York.

CuQ, E. (1896), en C. Daremberg, y E. Saglio (eds.), Dictionnaire des Antiquités Grecques et Romaines d'après les textes et monuments, vol. II. 2, pp. 1367-1409, París, s. v. Funus.

D’ Ambrosio, A., y S. De Caro (1983), Fotopiano e documentazione della necropoli di Porta Nocera. Un impegno per Pompei, Milán. 
D’ Ambrosio, A., y S. De Caro (1987), «La necropoli di Porta Nocera. Campagna di scavo 1983», en H. von Hesberg, P. Zanker, Römische Gräberstrassen. Seldbsdarstellung-Status-Standard, Múnich, pp. 199-229.

De Laet, S. J., P. Van Doorselaer, H. Spitaels y Thoen (1972), La nécropole Gallo-romaine de Blicquy (Hainaut-Belgique), Brujas.

De VISSCHER, F. (1963), Le droit des tombeaux romains, Milán.

Del Amo, M. (1971), Estudio crítico de la necrópolis de Tarragona, Tarragona.

- (1973), «Estudio preliminar sobre la romanización en el término de Medellín (Badajoz). La necrópolis de El Pradillo y otras villas romanas», Noticiario Arqueológico Hispánico, 2, pp. 55-88.

Delamare, H. E. (1850), «Exploration scientifique de l'Algérie pendant les années 1840-1845», Archéologie, 153, 7.

Delattre, H. E. (1881) De l'utilité d'une mission archéologique permanente à Carthage, Argel, 1881.

DelatTRE, R. P. (1888), «Fouilles d'un cimetière à Carthage», Revue Archéologique, $3^{\mathrm{a}}$ serie, pp. 151-174.

- (1896), Carthague. Nécropole punique de la colline de Saint-Louis, Lyon.

Deonna, W. (1959), «Cimetières des bébés», Revue archaéologique de l'Est et du Centre-Est, 10, pp. 24-27, 81-93; 177-191, 278-290.

DoOrSelaer, A. VAN (1967), Les nécropoles d'époque romaine en Gaule Septentrional. Dissertationes Archaeological Gandenses, X, Brujas.

Down, A., y M. Rule, (1971), Chichester Excavations, 1, Chichester.

Duprè, X. (1993), «Parc de la Ciutat-Quintà de Sant Rafael, Tarragona», Anuari d'intervencions arqueologicas, 261.

EnRíQueZ, J. J., y E. Gijón (1987), Arqueología urbana en Mérida. La necrópolis del Albarregas, Mérida.

ERICE, R. (1991), «Ficha catalográfica n. ${ }^{\circ} 43 »$, en VV. AA., Arqueología de Zaragoza: 100 Imágenes representativas, Zaragoza.

- (1995), Las fibulas del nordeste de la Peninsula Ibérica: siglo I a. C. al IV d. C., Zaragoza.

ESCRIVÀ, V., C. MARTíneZ y X. VidAL (2001), «Edeta kai Leiria. La ciutat romana d'Edeta de l'epoca romana a l' antiguitat tardana », Lauro, 9, pp. 13-95.

Escudero, F. de A. (1991), Fichas Catálogo n. ${ }^{\circ} 99$ y 100, en Arqueología de Zaragoza: 100 Imágenes Representativas, Zaragoza.

- y M. ${ }^{a}$ P. Galve (2006), «Vista de Caesaraugusta», catálogo de la exposición Civilización. Un viaje a las ciudades de la España antigua, Alcalá de Henares, antiguo Hospital Santa María La Rica (3 de octubre de 2006 a 7 de enero de 2007), pp. 189-197.

Eygun, F. (1933), Le cimetière gallo-romain des Dunes à Poitiers, Journal des fouilles du Père de la Croix, S. J. et rapports du Commandant Rothmann, publiés avec 
introduction, notes et illustrations, Poitiers, s. d. (extr. Des Mémoirs de la Societé des Antiquaires de l'Ouest, IX, $3^{\text {a }}$ serie).

Faber, A., FAsOld, P., STRUCK, M. y M. WitTeYeR (dirs.) (2007), Körpergräber des 1.-3. Jahrbunderts in der Römischen Welt, Internationales Kolloquium Frankfurt am Main (19-20 Nov. 2004).

Fabre, G. (1973), «Un affranchi impérial à Conimbriga: P. Aelius Ianuarius», Révue des Études Anciennes, LXXV, 1-2, pp. 111-125.

FASOLD, P. (1992), Römischer Grabbauch in Süddeutschland, Aalen.

- (2000), «Early Roman graves in southern Bavaria: a review», en J. Pearce, M. Millet, M. Struck (eds.), Burial, Society and Context in the Roman World, Oxford, pp. 181-191.

FATÁs, G. (1976), «De epigrafía cesaraugustana», Simposion de Ciudades Augústeas, II, pp. 103-114.

- y M. Martín Bueno (1977), Epigrafía romana de Zaragoza, Zaragoza.

FERDiÈre, A. (1993), Introducción al Coloquio Monde des morts, monde des vivants en Gaule rurale, Archea/ Ager (Orleans, 7-9 de febrero de 1992), Tours.

FernándeZ Galiano, D. (1976), «Una interesante tumba romana hallada en Complutum (Alcalá de Henares)», Noticiario Arqueológico Hispánico, 4, pp. 587-605.

Fernández Ugalde, A., y A. Martín MuÑoz (2006), «Excavación y extracción de una tumba romana a las afueras de Écija», Astigi Vetus, 2, pp. 111-124.

Feugère, M. (1993), Les Armes des Romains de la république à l'Antiquité Tardive, París.

FÈVRIER, P. A. (1965), Fouilles de Sétif. Les basiliques chrétiennes du quartier nordouest, París.

- (1991), «Incinèrations et inhumations dans le Maghreb antique», en M. Vidal (coord.), Incinérations et inhumations dans l'Occident romain aux trois prèmiers siècles de notre ère, Actes du Colloque International de ToulouseMontréjeau (IV ${ }^{\mathrm{e}}$ Congrès Archéologique de Gaule Méridionale), 7-10 octobre 1987, pp. 181-189.

- y A. GASPARY, (1966-1967), La nécropole orientale de Sétif. Rapport préliminaire sur les fouilles effectuées de 1959 à 1964, Bulletin d'Archeologie Argelienne, 2, pp. 11-93.

- y R. Guery (1980), «Rites funéraires de la nécropole orientale de Sétif», Antiquités Africaines, 15, pp. 91-124.

Floriani SQuarciapino, M. (1958), Scavi di Ostia. La Necropoli, parte I, vol. 3, Roma.

Floriano, A. (1934-1935), «Las necrópolis romanas de Mérida», en Homenaje a J. R. Mélida, Anuario del Cuerpo Facultativo de Archiveros, Bibliotecarios y Arqueólogos, III, Madrid, 1935. 
Floriano, A. (1944), «Excavaciones en Mérida (Campañas de 1934 y 1936)», Archivo Español de Arqueologia, 17, pp. 169-172.

FUENTES, A. (1991), «Incinération et inhumation dans la moitié nord de l'Espagne au cours des trois premiers siècles de notre ère», en M. Vidal (coord.), Incinérations et inhumations dans l'Occident romain aux trois prèmiers siècles de notre ére, Actes du Colloque International de Toulouse-Montréjeau (IV Congrès Archéologique de Gaule méridionale), 7-10 octobre 1987, pp. 91-106.

Galliou, P. (1991), «Inhumation et incinération dans l'ouest de la Gaule romaine», en M. Vidal (coord.), Incinérations et inhumations dans l'Occident romain aux trois premiers siècles de notre ére, Actes du Colloque International de Toulouse-Montréjeau (IV ${ }^{\mathrm{e}}$ Congrès Archéologique de Gaule Méridionale), 7-10 octobre 1987, pp. 227-229.

Galve, M. ${ }^{a}$ P. (1990), «Arqueología medieval en Zaragoza», en Estado actual de la Arqueología en Aragón, II, pp. 321-332.

- (1991), «La necrópolis de la Puerta de Toledo», en VV. AA., Zaragoza. Prebistoria y Arqueología, Zaragoza, pp. 45-46.

- (1993), «El mundo funerario de Caesaraugusta», en Huellas del pasado. Aspectos de Zaragoza a través del patrimonio municipal, Zaragoza, pp. 22-24.

- (1995), «Necrópolis islámica de la puerta de Toledo (Zaragoza): nuevas excavaciones», en M. P. Torres y M. Acién (eds.), Estudios sobre cementerios islámicos andalusíes, Málaga, Estudios y ensayos, Universidad de Málaga, pp. 117-136.

- (2004), «Una ciudad consolidada: Caesaraugusta a mediados del siglo I», en Visiones de una ciudad, Zaragoza, pp. 15-33.

- (en prensa), «El espacio urbano en la Zaragoza islámica», I Jornadas de Arqueología Medieval en Aragón: balances y novedades, Teruel-2006.

- y J. A. BenAVEnTE (1991), «Las excavaciones arqueológicas de la necrópolis islámica de la puerta de Toledo», en E. Adiego y cols., Las necrópolis de Zaragoza, Cuadernos de Zaragoza, 63, Zaragoza, pp. 87-98.

- y J. A. Benavente (1992), «La necrópolis islámica de la puerta de Toledo de Zaragoza», en Actas del III Congreso de Arqueología Medieval Español, t. II, Oviedo, pp. 383-390.

- y M.a A. Magallón (1975), «La epigrafía romana de Caesaraugusta», en Miscelánea a A. Beltrán, Zaragoza, pp. 213-231.

- et al. (1996), Los antecedentes de Caesaraugusta. Estructuras domésticas de Salduie (calle Don Juan de Aragón, 9, Zaragoza), Zaragoza.

- e I. LORENZO (1994), «La necrópolis occidental de Caesaraugusta», en La ciudad en el mundo romano, Actas del XIV Congreso Internacional de Arqueología Clásica, Tarragona, pp. 164-165. 


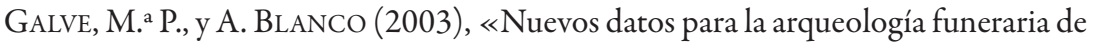
Caesaraugusta: las tumbas paleocristianas de la calle Mosén Pedro Dosset (vial, Zaragoza)», Salduie, II, 2001-2002, pp. 409-414.

- A. Blanco y J. L. Cebolla (2005), «Edificio de culto paleocristiano en Zaragoza», en VI Reunió d'Arqueologia Cristiana Hispànica, Valencia (2003), Barcelona, pp. 483-496.

- A. Blanco y J. L. Cebolla (2007), La calle Alfonso I de Zaragoza. Hallazgos arqueológicos durante las obras de peatonalización en 2001, Zaragoza.

- y A. Mostalac (2007), «Las necrópolis», en F. Beltrán (coord.), Caesar Augusta. Las capitales provinciales de Hispania, Roma, pp. 85-96.

GarbSCH, J. (1965), Die Norisch-Pannonische faruentracht im 1. und 2. Jahrbundert, Múnich.

GARCÍA IgLESIAS, L. (1979), Zaragoza, ciudad visigoda, Zaragoza.

García PrósPer, E., y P. GUérin (2002), «Nuevas aportaciones en torno a la necrópolis romana de la calle Quart de Valencia (s. II a. de C.-IV d. de C.)», en D. Vaquerizo, (ed.), Espacios y usos funerarios en el Occidente romano, vol. I, Córdoba, pp. 203-216.

GarCía y Bellido, A. (1949), Esculturas romanas en España y Portugal, Madrid.

- (1962), Mérida: la gran necrópolis romana de la salida del puente. Excavaciones Arqueológicas en España, 11, Madrid.

GonZález Villaescusa, R. (1993), «Monde des morts et monde des vivants en Pays Valencien (Hispania Tarraconensis)», en A. Ferdière (ed.), Monde des morts, monde des vivants en Gaule rurale, Actas del Coloquio celebrado en Orleans en 1992, Tours, pp. 411-416.

- (2001), El mundo funerario romano en el País Valenciano. Monumentos funerarios y sepulturas entre los siglos I a. de C.- VII d. de C., Madrid-Alicante.

Goudineau, Ch. (1968), La céramique arétine lisse, París.

Gros, P. (1965-1966), «Rites funéraires et rites d'inmortalité dans la liturgie de l'apothéose impériale», Annuaire de l'École pratique des Hautes Études, IV sect., 477-490.

GSELL, St. (1901), Monuments antiques de l'Algerie, II, 48 (citados por Moretti, 194, nota 2), París.

GuÉRY, R. (1967), La nécropole orientale de Sitifis (Sétif, Algérie): Fouilles de 19661967, París.

- (1987), «Les marques de potiers sur terra sigillata découvertes en Algérie. II. Sigillée tardo-italique», Antiquités Africaines, 23.

GuRT, J. M., y J. M. MACíAS (2002), «La ciudad y el territorium de Tarraco: el mundo funerario», en D. Vaquerizo (ed.), Espacios y usos funerarios en el Occidente romano, vol. I, Córdoba, pp. 87-112. 
HABEREY, W. (1938), «Ein frührömisches Brandgrab mit Spenderöhe aus Köln», en Festschrift für August Oxé, pp. 197-204.

HatT, J. J. (1951), La Tombe Gallo-romaine, París, 1986.

- (1967), «Mausolée et four crématoire gallo-romaines á Mackwiller (BasRhin)», Gallia, Xxv, fasc. 1, pp. 75-85.

- (1986), La Tombe gallo-romaine, París.

Hayes, J. W. (1972), Late Roman Pottery. A Catalogue of Roman Fine Wares, Londres. HidALGO, R. (2001), «Las transformaciones provocadas por la implantación del cristianismo», en D. Vaquerizo (coord.), Funus Cordobensium. Costumbres funerarias en la Córdoba romana, Córdoba, pp. 248-249.

Hosdez, C., y A. JacQues (1989), La Nécropole à incinération de Baralle (Pas-deCalais), Nord-Ouest Archéologique, 2.

IvANOV, I. (1910) «Otcet za razkopkit pri kadin-most (Kioustendil)», Izvestia ha bylgarskoto Archeologhistchesko Droujestvo I, 1910, 173-177, figs. 17-19, según referencia de Berciu y Wolsky, 1970, 938, nota 2, fotografía en la figura 18.

JONES, R. F. J. (1981), Cremation and Inhumation-Change in the third century, BARIntS, 109 (i).

Jovanovic, A. (2000), «Romanization and ethnic elements in burial practise in the southern part of Pannonia Inferior and Moesia Superior», en J. Pearce, M. Millet, M. Struck (eds.), Burial, Society and Context in the Roman World, Oxford.

JuLIÁ, D. (1965), Les monuments funéraires en forme de demi-cylindre dans la province romaine de Tarragonaise, Mélanges de la Casa de Velázquez, París.

KenRICK, P. M. (1985), «The fine pottery», en Excavations at Sidi Khrebish, Benghazi (Berenice), III. Libya Antiqua, Suppl. 5, Trípoli.

KocKel, V. (1987), «Im Tode Gleich? Die sullanischen Koloniste und ihr kulturelles Gewicht in Pompeji am Beispiel der Nekropolen», en H. Von Hesberg y P. Zanker (eds.), Römische Gräberstrassen. Selbstdarstellung-Status-Estandar, Coloquio de Múnich (28-30 de octubre de 1985).

Kovrig, I. (1937), Die Haupttypen der kaiserzeitlichen Fibeln in Pannonien. Dissertationes Pannonicae, II, 4, Budapest.

Kremer-Molitor, G. (2001), Antike Grabbauten in Noricum. Katalog und Auswertung von Werkstücken als Beitrag zur Rekonstruktion und Typologie.

- (2006), «L'architecture funéraire monumentale dans le Norique, la Pannonie et la Dacie», en J. C. Moretti y D. Tardy (eds.), L'Architecture funéraire monumentale. La Gaule dans l'Empire Romain, Actas del Coloquio Henri-Prades, Lattes, 11-13 de octubre de 2001), pp. 79-98.

LA RocCA, E. (1984), La Riva a Mezzaluna. Culti, agoni, monumenti funerari presso il Tevere nel Campo Marzio occidentale. Studi e materiali del Museo della Civiltà romana, n. ${ }^{\circ}$ 11, Roma. 
Lamboglia, N. (1943), Recensión de Ch. Simonett, Tessiner Gräberfelder. Rivista di Studi Liguri, IX, 163.

LANCEL, S. (1970), «Tipasitania IV: la nécropole occidentale de la porte de Césarée, rapport préliminaire», Bulletin d'Archéologie Argelienne, 4, pp. 149-266.

Lange, M., H. SchutKowsky, S. Hummel y B. Herrmann (1987), A bibliography on Cremation, Leichenhand-Bibliographie, Pact. 19, Estrasburgo.

LE BoHeC, Y. (1987), «Peut-on "compter la mort" des soldats de la III ${ }^{e}$ Légion Auguste?», en F. Hinard (dir.), La mort, les morts et l'au-delà dans le monde romain, Actes du Colloque de Caen, 20-22 Novembre 1985, Caen, pp. 53-64.

LEQUOY, M. Cl. (1991), «Inhumations et incinérations dans deux nécropoles de la Basse Vallée de la Seine: Rouen et Vatteville-la-Rue», en M. Vidal (coord.), Incinérations et inhumations dans l'Occident romain aux trois premiers siècles de notre ère, Actes du Colloque International de Toulouse-Montréjeau (IV ${ }^{\mathrm{e}}$ Congrès Archéologique de Gaule méridionale), 7-10 octobre, Toulouse, pp. 227-236.

LeVEAU, Ph. (1987a), «Nécropoles et monuments funéraires à Caesarea de Maurétania», en H. von Hesberg y P. Zanker, Römische Gräberstrassen. Selbstdarstellung-Status-Estandar, Coloquio de Múnich (28-30 de octubre de 1985), pp. 281-290.

- (1987b), «Le Problème de l'Organisation de l'Espace Funéraire dans les Nécropoles Romaines», pp. 15-17, en VV. AA., 1987, Nécropoles à Incinération du Haut Empire. Rapports Archéol. Prél. Rhône-Alpes, 4, Direct. Ant. Hist. Rhône-Alpes, Lyon.

LópeZ, J. R. (1970), La necrópolis de Eras del Bosque. Publicaciones de la Institución Tello Téllez de Meneses, 40.

LÓPEZ ViLAR, J. (1999-2000), «Consideraciones sobre las cupae i altres estructures funéraries afins», Butlletí Arqueòlogic, 21-22, Tarragona, pp. 65-104.

Loriente, A., y A. Oliver (1992), L'antic Portal de Magdalena, Lérida (Monografies d'Arqueologia Urbana, 4).

Lostal, J. (1979), Arqueología del Aragón romano, Caesarangusta, 47-48, Zaragoza.

Lucas, M. R., M. A. Alonso, M. C. Blasco, M. C. Fernandez Ochoa e I. L. Rubio De Miguel (1982), «Necrópolis romana de La Torrecilla (Getafe, Madrid)», Noticiario Arqueológico Hispánico, 13, pp. 215-245.

Luengo, J. M. (1950), Excavaciones en el castro de Meirás y su necrópolis, Informes y Memorias, 23.

Magallón, M. A. (1991), en VV. AA., Arqueología de Zaragoza: 100 imágenes representativas, ficha $\mathrm{n}^{\circ} 26$.

Mansuelli, G. (1963), Enciclopedia dell'Arte Antica, V, s. v. Monumento funerario, pp. 184-201. 
Marcos Pous, A. (1961), «Dos tumbas emeritenses de incineración», Archivo Español de Arqueología, 34, pp. 90-103.

MARTínEZ, F., L. RIVAS y J. M. ARIAS (1989), «Monumentos funerarios romanos de Llíria », Lauro, 4, pp. 243-251.

Mau, A. (1888), Scavi di Pompei. Sepolcri della via Nucerina, Mitt. des Kaiserl. deutsch archaeol. Inst. Röm. Abl. III, pp. 125-141.

MazZeo, L. (1971), «Terra Sigillata Nord-italica», Atlante delle Forme Ceramiche, II. MÉlida, J. R. (1925), Catálogo Monumental de España. Provincia de Badajoz, I, Madrid.

MenZel, H. (1956), Antike Lampen in Römisch-germanische Zentral-museum zu Mainz, Mainz.

Molano, J., y M. De Alvarado (1991-1992), «El enterramiento de la c/ Circo Romano, n. ${ }^{\circ}$ 10: aportación al conocimiento con tubos de libaciones en Augusta Emerita», Anás, IV-V, Mérida, pp. 161-173.

MoretTi, G. (1921), «Trovamenti fortuiti nella zona dell'antico Falerio», Notizie degli Scavi, XVIII, 7, 8, pp. 179-196.

MorRIS, I. (1992), Death-ritual and social structure in Classical Antiquity, Cambridge.

MostalaC, A. (1994), Los sarcófagos romano-cristianos de la provincia de Zaragoza. Análisis iconográfico e iconológico, Zaragoza.

MÜLLER, G. (1977), Die römischen Gräberfelder von Novaesium, Novaesium VII, Berlín.

Neraudau, J. P. (1987), «La loi, la coutume et le chagrin. Réflexions sur la mort des enfants», en La mort, les morts et l'au-delà dans le monde romain, Actas del Coloquio de Caen, 1985, París, pp. 195-208.

Nierhaus, R. (1959), Das römische Brand-und Körpergräberfeld «Aufder Steig» in Stuttgart-Bad Cannstatt. Die Ausgrabungen im Jahre 1955 (Veröffentlichungen des staatlichen Amstes für Denkmalpflege Stuttgart, Reihe A, Vor-und Frühgeschichte, Heft, 5), Stuttgart, 1959.

- (1969), «Römerzeitliche Bestattungsitten im nördlichen Gallien: autochtones und mittelmeerländisches. Bemerkungen zu einen kürzlich erschienen Buch», Helinium, 9, pp. 243-262.

Nock, A. D. (1932), «Cremation and Burial in the Roman Empire», The Harvard Theological Review, XXV, pp. 321-359.

Nock, F. (1985), La Conversione. Società e religione nel mondo antico, Roma-Bari.

Nogales, T., y J. Márquez (2002), «Espacios y tipos funerarios en Augusta Emérita», en D. Vaquerizo (ed.), Espacios y usos funerarios en el Occidente romano, vol. I, Córdoba, pp. 113-144.

Nowicka, M. (1969), La maison privée dans l'Egipte ptolemaïque, Varsovia-Wroclaw. 
Oeconomus, G. P. (1921), De profussionem receptaculis sepulcralibus inde ab antiquissimis temporibus usque ad nostram fere aetatem usitatis, Bibliotheca Societatis Archaeologicae Athenarum, XXI.

OlCINA, M. (s. d.), Guia de los monumentos romanos y del castillo de Sagunto, en C. Aranegui (ed.).

OrdóNEEZ, S., y S. GARCía Dils (2004), «Nuevas inscripciones de Romulenses. Con un apéndice sobre el paisaje periférico septentrional de Romula Hispalis», Romula, 3, Sevilla, pp. 149-172.

ORSI, P. (1913), «Di alcuni ipogei recentemente scoperti a Siracusa», Not. Scavi, X, 7, pp. 257-280.

Palol, P. (1953), «Algunos aspectos históricos y arqueológicos del cristianismo en la Tarraconense y en las Galias», Psana, 6, pp. 141-167.

- (1972), «Una tumba romana de Toledo y los frenos de caballo hispanos del Bajo Imperio», Pyrenae, 8, pp. 133-146.

PANIER, D. (1987), «Inhumations et incinérations aux trois premieres siècles d'ère: l'état des questions en Suisse», Coll. Toul., en M. Vidal, Incinérations et inhumations dans l'Occident romain aux trois premiers siècles de notre ère, Actes du Colloque International de Toulouse-Montréjeau ( $\mathrm{IV}^{\mathrm{e}}$ Congrès Archéologique de Gaule Méridionale), 7-10 octobre 1987, pp. 191-201.

Pareggiani, G. (1984), «Brevi note su alcuni aspetti del rituale funerario», en VV. AA., La necropoli romana di Voghenza, Ferrara, pp. 81-83.

PArIs, P., et al. (1926), Fouilles de Belo (Bolonia, Province de Cádiz) (1917-1921). II. La nécropole, París.

Partridge, C. (1981), Skeleton Green, Londres, Britania Monographs, Series 2.

Patek, E. (1942), Verbreitung und Herkunft der römischen Fibel-typen von Pannonien, Dissertationes Pannonicae, II, 19, Budapest.

Pearce, J., M. Millet y M. Struck (eds.) (2000), Burial, Society and Context in the Roman World, Oxford.

PéreX, M. J., y M. UnZU (1988), «Emplazamiento de Iturissa, mansio en la vía de Astorga a Burdeos», Trabajos de Arqueología Navarra, 7, pp. 335-339.

Pérez, A. (1991), Lleida romana, Lérida.

PHILPOTT, R. (1991), Burial practices in Roman Britain: a survey of grave treatment and furnishing Ad 43-410, BAR 219.

PICARD, G. Ch. (1965-1966), «La chronologie et l'évolution stylistique des monuments funéraires de Mactar (Tunisie)», Bulletin Archéologique du Comité des Travaux Historiques, I-II, pp. 159-160.

Pilet, C. (1980), «La nécropole de Frenouville. Étude d'une population de la fin du $\mathrm{III}^{\mathrm{e}}$ à la fin du VII ${ }^{\mathrm{e}}$ siècle», BAR International Series, 83 (111). 
Planson, E. (ed.) (1982), La nécropole gallo-romaine Les Bolards. Nuit Saint-Georges, CNRS, París.

PRIEUR, J. (1986), La mort dans l'antiquité romaine, De mémoire d'homme: l'histoire. Université. Edit. Ouest-France.

Rada y Delgado, J. de la (1885), La necrópolis de Carmona, Madrid.

REBECCHI, F. (1991), «L'importance de l'ensevelissement dans la civilisation-romano-italique de l'Italie Septentrional», en M. Vidal (coord.), Incinérations et inhumations dans l'Occident romain aux trois premiers siècles de notre ére, Actes $\mathrm{du}$ Colloque International de Toulouse-Montréjeau (IV Congrès Archéologique de Gaule Méridionale), 7-10 octobre 1987, pp. 149-161.

REECE, R. (1982), «Bones, bodies and dis-ease», Oxford Journal Archaeology, 1 (3), pp. 347-358.

- (1991), «Incinération et inhumation en Grande-Bretagne romaine jusqu'en 300 ap. J.-C.», en M. Vidal (coord.), Incinérations et inhumations dans l'Occident romain aux trois premiers siècles de notre ère, Actes du Colloque International de Toulouse-Montréjeau (IV ${ }^{\mathrm{e}}$ Congrès Archéologique de Gaule Méridionale), 7-10 octobre 1987, Toulouse, pp. 219-225.

Remesal, J. (1979), La necrópolis sudeste de Belo. Excavaciones Arqueológicas en España, 104.

RemolÁ, J. A. (2004), «Arquitectura funeraria», en X. Dupré (ed.), Tarragona. Colonia Iulia Urbs Triumphalis Tarraco. Las capitales provinciales de Hispania, 3, Roma, pp. 83-95.

Rhodes, M. (1980), «Nailed Shoes», en D. Jones y M. Rhodes, Excavations at Billingsgate Buildings. Lower Thames Street, London 1974, London Middlesex Archaeological Society. Special Paper 4, pp. 99-128.

Ribera, A. (1996), «La topografía de los cementerios romanos de Valentia», Saitabi, 46, pp. 85-99.

- et al. (1989), Guía Arqueológica de Valencia, Valencia.

RiCHARD, J. C. (1966), «Incinération et inhumation aux funérailles impériales: Histoire du rituel de l'apothéose pendant le Haut-Empire», Latomus, XXV, fasc. 4, oct.-dic., pp. 784-804.

- (1978), «Recherches sur certains aspects du culte impérial: les funérailles des empereurs aux deux premiers siècles de notre ère», Aufstieg und Niedergang der römischen Welt, II, XVI, 2, 1978, pp. 1121-1134.

Rivas, L., J. M. ARIAS y F. MARTínez (1990), «Nuevas aportaciones en torno a la arquitectura funeraria romana: el edificio $n .^{\circ} 2$ de la necrópolis de Llíria (Valencia)», Lauro, 5, pp. 159-171.

Rosselló, M., y E. Ruiz VAL (1996a), «La necrópolis romana de la c/ Virgen de la Misericordia, Valencia. Siglos I a. de C.-III d. de C.», en J. D. Villalain, F. Gómez Bellard (eds.), II Congreso Nacional de Paleopatología, Valencia, pp. 183-193. 
Rosselló, M., y E. Ruiz Val (1996b), «La necrópolis occidental de la Valencia romana», Saitabi, 46, pp. 147-168.

SÁNCHez Ramos, I. (2006), «La cristianización de las áreas funerarias en la Antigüedad tardía. La situación en Córdoba», D. Vaquerizo y J. F. Murillo (eds.), El concepto de lo provincial en el mundo antiguo. Homenaje a la Prof. ${ }^{a}$ Pilar León, Córdoba, pp. 367-380.

Sanmartí, J. (1984), «Els edificis sepulcrals romans dels Països Catalans, Aragó i Múrcia», Fonaments, 4, pp. 87-161.

Schattner, Th. G. (2003), Munigua. Cuarenta años de investigaciones, Sevilla.

Schindler, M., y S. Scheffenegger (1977), Die glatte rote Terra Sigillata vom Magdalensberg, Kärtner Museumsschriften, 62, Klagenfurt.

SenNa GiesA, G. (1985), Angera romana, Università degli Studi di Milano.

SERRA, J. (1944), «Sepulcros y ataúdes de la necrópolis de San Fructuoso (Tarragona)», Ampurias, vI, pp. 179-207.

Sillières, P. (1995), Baelo Claudia. Une cité romaine de Bétique, Madrid.

Simón y NieTO, F. (1948), «Noticia de una necrópolis y un bosque sagrado (Palencia)», Archivo Español de Arqueología, 71, pp. 146-164.

Sogliano, A. (1886), Notizie degli Scavi, pp. 334-337.

- (1887), Notizie degli Scavi, pp. 451-458.

Soprano, P. (1961), «Via Nucerina. Sepolcri di età romana», Notizia Scavi, VIII, XV, pp. 189-200.

Steinby, E. M. (1987), «La necropoli della Via Triumphalis. Planificazione generale e tipologia dei monumenti funerari», en H. Von Hesberg y P. Zanker (eds.), Römische Gräberstrassen. Selbstdarstellung-Status-Estandar, Coloquio de Múnich (28-30 de octubre de 1985), pp. 85-110.

TAGLietTi, F. (1991), «La diffusion de l'inhumation à Rome: la documentation archéologique», en M. Vidal (coord.), Incinérations et inhumations dans l'Occident romain aux trois premiers siècles de notre ère, Actes du Colloque International de Toulouse-Montréjeau (IV ${ }^{\mathrm{e}}$ Congrès Archéologique de Gaule Méridionale), 7-10 octobre 1987, Toulouse, pp. 163-171.

- (1991), «Incinérations et inhumations dans l'Occident romain aux trois premiers siècles de notre ère: Rome et Latium», en M. Vidal (coord.), Incinérations et inhumations dans l'Occident romain aux trois premiers siècles de notre ère, Actes du Colloque International de Toulouse-Montréjeau (IV ${ }^{\mathrm{e}}$ Congrès Archéologique de Gaule Méridionale), 7-10 octobre 1987, Toulouse, pp. 88-91.

- (2001), «Ancora su incinerazione e inhumazione: la necropoli dell'Isola Sacra», en M. Heinzelmann et al. (eds.), Culto dei morti e costumi funerari romani, Wiesbaden, pp. 149-158. 
Taracena, B. (1948), «Las necrópolis romanas de Palencia», Archivo Español de Arqueologia, 71, pp. 144-146.

TARRADELL, M. (1965), «Enterramientos infantiles en el interior de habitaciones ibéricas», Pyrenae, 1, pp. 174-175.

Teposu Marinescu, L. (1982), Funerary Monuments in Dacia Superior and Dacia Porolissensis, BAR International Series, 128, Oxford.

Terre, E. (1993), «Carrer de Rovira i Virgili, 3, Tarragona», Anuari d'intervencions arqueológicas, 260.

TopáL, J. (2000), «Connection between funerary rites and ethnic groups in the cemeteries of north-eastern Pannonia», en J. Pearce, M. Millet y M. Struck (eds.), Burial, Society and Context in the Roman World, Oxford.

Torelli, M. (1968), «Monumenti funerari romani con freggio dorico», Dialogui di Archaeologia, 2, pp. 32-33.

Toynbee, J. M. C. (1971), Death and Burial in the Roman World, Londres.

Tupman, Ch. (2005), «The cupae of Iberia in their monumental contexts: a study of the relationship between social status and commemoration with barrel shaped and semi-cylindrical tombstones», en J. Bruhn, B. Croxford y D. Grigoropoulos (eds.), TRAC 2004. Proceedings of the Fourteenth Annual Theoretical Roman Archaeology Conference, Oxbow Books, pp. 119-132.

TURCAN, R. (1958), «Origines et sens de l'inhumation à l'époque impériale», Révue des Études Anciennes, 60, pp. 323-347.

UnzU, M., y M. J. PÉREX (1997), «La cultura funeraria en Navarra en época romana», Isturitz, 9, pp. 795-815.

UsCatescu, A. (2004), «L’època antiga a Granollers: dels orìgens a la Antiguitat tardana», en Atles d'Arqueologia Urbana de Catalunya, vol 1. Granollers, Barcelona, pp. 37-100.

VAN DE WEERD, A. (1965), «Le problème des mobiliers funéraires avec armes en Gaule septentrional à l'époque du Haut-Empire romain», Helinium, 5, pp. 118-135.

VAN OSSel, P. (1991), «Incinération et inhumation dans le Nord de la Gaule Belgique durant le Haut-Empire», en Incinérations et Inhumations dans l'Occident romain aux trois premiers siècles de notre ère, Actes du Colloque International de Toulouse-Montréjeau (IV Congrès Archéologique de Gaule Méridionale), 7-10 octobre 1987, Toulouse, pp. 209-217.

Vaquerizo, D. (1994), «Las necrópolis de Colonia Patricia Corduba», en La ciudad en el mundo romano, II, Tarragona, pp. 416-417.

- (coord.) (2001), Funus Cordubensium. Costumbres funerarias en la Córdoba romana, Córdoba.

- (2002), «Espacios y usos funerarios en Corduba», en D. Vaquerizo (ed.), Espacios y usos funerarios en el Occidente romano, vol. II, pp. 143-200. 
VAQUeRIZO, D. (2006), «Sobre la tradición púnica o los influjos norteafricanos en algunas manifestaciones arqueológicas del mundo funerario hispano-bético de época pleno-imperial. Una revisión crítica», en D. Vaquerizo y J. F. Murillo (eds.), El concepto de lo provincial en el mundo antiguo. Homenaje a la Prof. ${ }^{a}$ Pilar León, II, Córdoba, pp. 317-364.

- (2007), «Crematio et humatio in Hispania: Cordubensium mos (2. Jahrhundert v. Chr. Bis zum 2. Jahrhundert n. Chr.)», en A. Faber, P. Fasold, M. Struck y M. Witteyer (Dirs.), Körpergräber des 1.-3. Jahrbunderts in der Römischen Welt, Internationales Kolloquium Frankfurt am Main (19-20 Nov. 2004), pp. 271-290.

- J. A. Garriguet y S. Vargas (2005), «La Constancia». Una contribución al conocimiento de la topografía y los usos funerarios en la Colonia Patricia de los siglos iniciales del Imperio, Córdoba.

- J. A. GARriguet y A. León (eds.) (2007), Espacios y usos funerarios en la ciudad histórica. Anales de Arqueología Cordobesa, 2006, 17.

VARGAS, S. (2002), «El conjunto funerario de La Constancia (Córdoba). Ajuares y cronología», en D. Vaquerizo (ed.), Espacios y usos funerarios en el Occidente romano, vol. II, pp. 297-310.

VERNHET, A. (1991), «Inhumations en Rouergue aux trois premieres siècles», en M. Vidal (coord.), Incinérations et inhumations dans l'Occident romain aux trois premiers siècles de notre ère, Actes du Colloque International de ToulouseMontréjeau (IV ${ }^{\mathrm{e}}$ Congrès Archéologique de Gaule Méridionale), 7-10 octobre 1987, Toulouse, pp. 71-72.

Vidal, N., y J. M. Campos (2007), «Las necrópolis de Onuba», Anales de Arqueologia Cordobesa (2006), 17, pp. 13-34.

VIDAL, M. (coord.) (1991), Incinérations et inhumations dans l'Occident romain aux trois premiers siècles de notre ère, Actes du Colloque International de ToulouseMontréjeau (IV ${ }^{e}$ Congrès Archéologique de Gaule Méridionale), 7-10 octobre 1987, Toulouse.

VISMARA, C. (1991), «L'apport des textes antiques», en M. Vidal (coord.), Incinérations et inhumations dans l'Occident romain aux trois premiers siècles de notre ère, Actes du Colloque International de Toulouse-Montréjeau (IV Congrès Archéologique de Gaule Méridionale), 7-10 octobre 1987, Toulouse, pp. 107-147.

Vollmer, A., y A. López BORGOÑOZ (1995), «Nuevas consideraciones sobre las variaciones en el ritual funerario romano (siglos I-III d. de C.)», en Actas del XXII Congreso Nacional de Arqueología (Vigo, 1993), pp. 367-372.

- (1995), «Nuevas hipótesis sobre los motivos de la ubicación de la necrópolis de les Corts y su relación con la ciudad romana de Ampurias (Girona)», en Actas del XXII Congreso Nacional de Arqueología (Vigo, 1993), pp. 373-381. 
VV. AA. (1970), Sibari. Scavi al Parco del Cavallo (1960-1962; 1969-1970) e agli Stombi (1969-1970). Notizie Scavi, XXIV, 1970, III Suppl.

- (1984), València romana, Valencia.

- (1987a), Els enterraments del Parc de la Ciutat i la problemática funeraria de Tarraco, Memòries d'Excavació 1, Taller Escola d'Arqueologia, Tarragona.

- (1987b), Les hommes et leurs sépultures dans les Pyrénées Occidentales depuis la Préhistoire, Pau, 1987 = Archéologie des Pyrénées Occidentales, 7.

- (1991), Incinérations et inhumations dans l'Occident romain aux trois premiers siècles de notre ère. Actas del IV Congrés Archéologique de la Gaule méridionale. Toulouse-Montrejeau (7-10 Oct.).

- (1991), Zaragoza. Prehistoria y Arqueología, Zaragoza.

- (1993), Las Huellas del Pasado. Aspectos de Zaragoza a través de su Patrimonio Municipal, catálogo de la exposición.

- (1997), Crónica del Aragón Antiguo. 1994-1998. De la Prebistoria a la Alta Edad Media. Caesaraugusta, 72, Zaragoza.

Wenham, L. P. (1968), The Romano-British cemetery at Trentholme Drive, York, Stationery Office, Londres.

WheELeR, M. (1929), «A Roman pipe-burial from Caerleon, Monmonthshire», Antiquaries Journal, IX, 1929, pp. 1-7.

Whirr, MC., L. Viner y C. Wells (1982), Romano-British cemeteries at Cirencester, Cirencester Excavations, Cirencester, 2.

Whiting, W., W. HaWley y T. MAY (1931), The Roman cemetery at Ospringe, Kent, Londres, Soc. Ant. Lond., Report 8.

WHYTEHEAD, R. (ed.) (1986), «The excavation of an area within a Roman cemetery at West Tenter Street, London E 1», Trans London Middlesex Archaeological Society, vol. 37, pp. 23-124.

WOLSKY, B., y I. BERCIU (1973), «Contribution au probleme des tombes romaines à dispositif pour les libations funéraires», Latomus, XXXII, 2, pp. 370-390. 


\section{Fuentes clásicas}

\section{FuLGENCIO}

Fabii Planciadis Fulgentii VC Opera, edición de R. Helm (1898), Bibliotheca Scriptorum Graecorum et Romanorum Teubneriana, Leipzig.

Juvenal

A. Persii Flacci et D. Iunii Iunenalis Saturae, edición de W. V. Clausen (1966), Scriptorum Classicorum Bibliotheca Oxoniensis, Oxford.

Macrobio

Saturnalia. Edición de J. Willis (1963). Bibliotheca Scriptorum Graecorum et PLINIO Romanorum Teubneriana. Leipzig.

C. Plinius Secundus. Naturalis Historia, edición de L. Ian y C. Mayhoff (19671970), vol. I-VI. Bibliotheca Scriptorum Graecorum et Romanorum Teubneriana, Leipzig.

Plutarco

Moralia, edición de G. N. Bernadakis (1889), Bibliotheca Scriptorum Graecorum et Romanorum Teubneriana, Leipzig.

POMPEYO FESTO

De uerborum significati quae supersunt cum Pauli epitome nn, 32 (bustum). Edición de W. M. Lindsay (1913), Leipzig; reimpr. Hildesheim, G. Olms, 1965.

PRUDENCIO

Himno a los Mártires, edición de M. J. Bayo (1946), Madrid, Instituto Antonio de Nebrija.

SERVIO

Seruii in Vergili carmina comentarii. Edición de E. K. Rand (1946). Harvard University Press. Cambridge-Massachusetts.

TÁCITO

Cornelii Taciti libri qui supersunt. Edición de S. Borzák (1992), Bibliotheca Scriptorum Graecorum et Romanorum Teubneriana, Leipzig.

TERTULIANO

Tertulliani Opera. Tomo II. Edición de J. H. Waszink (1954), Corpus christianorum- Latina 2, Turnholti. 



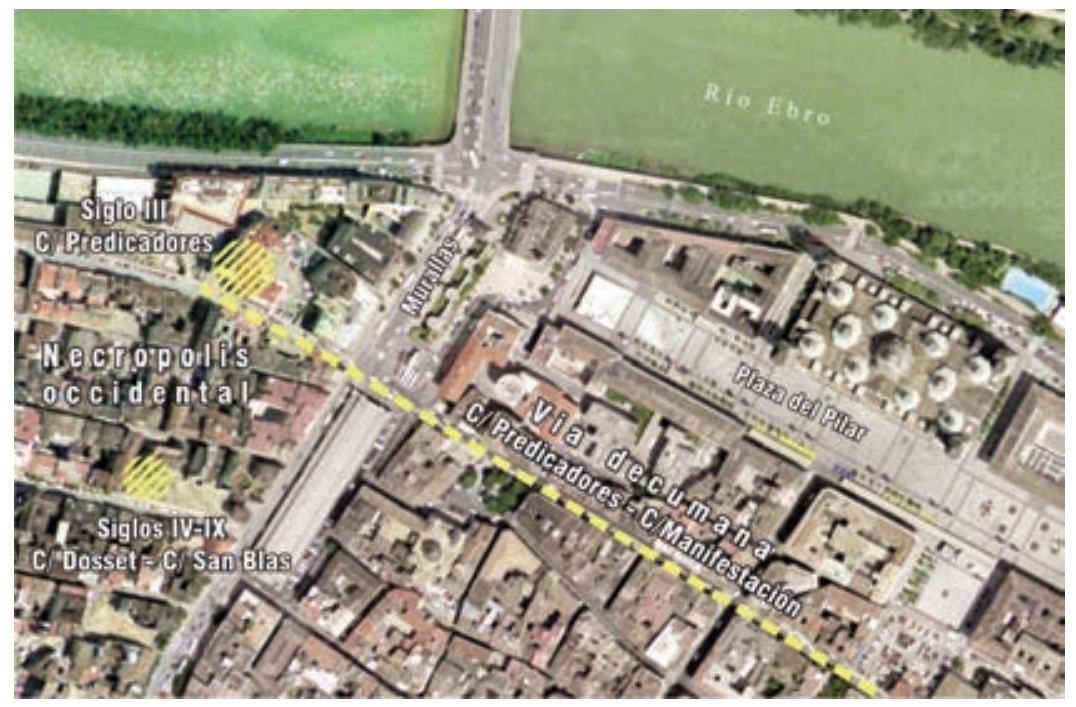

1. Vista aérea de Zaragoza con la situación de la necrópolis occidental.

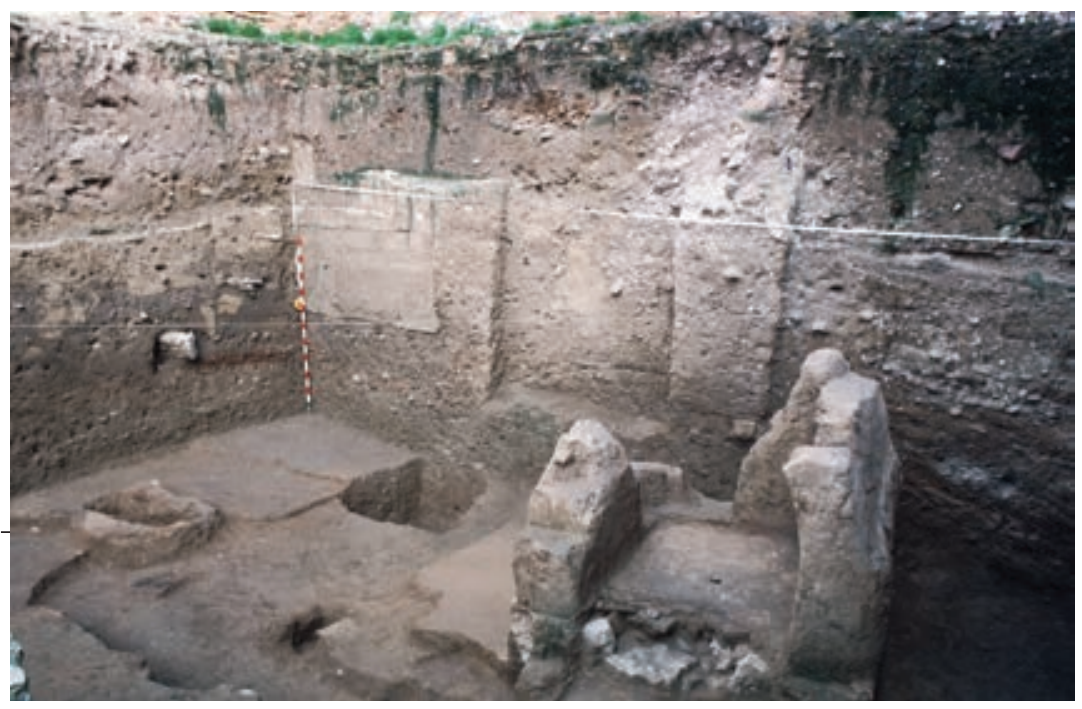

2. El solar excavado en la calle Predicadores, 24-26. 


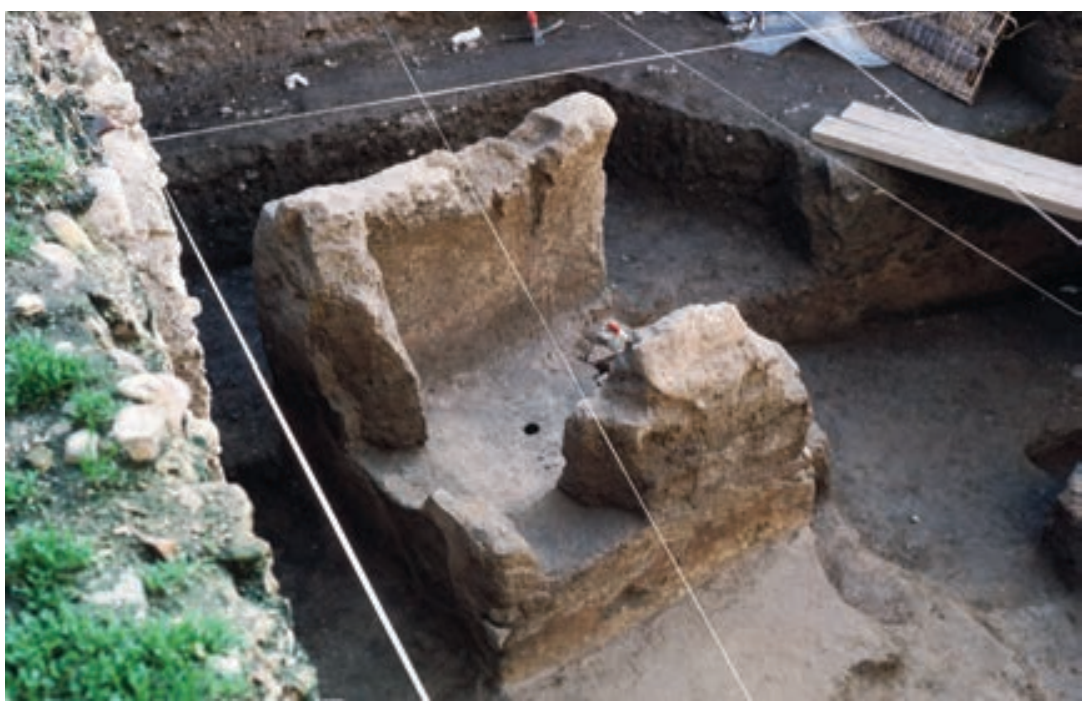

3. El edículo.

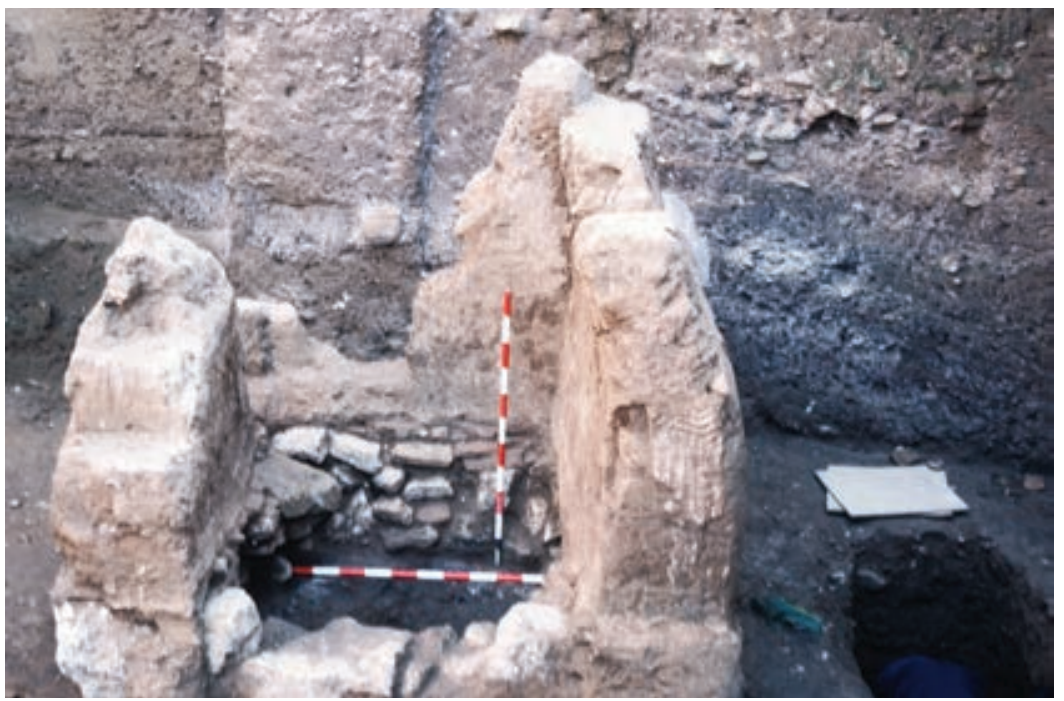

4. Fachada principal del edículo. 


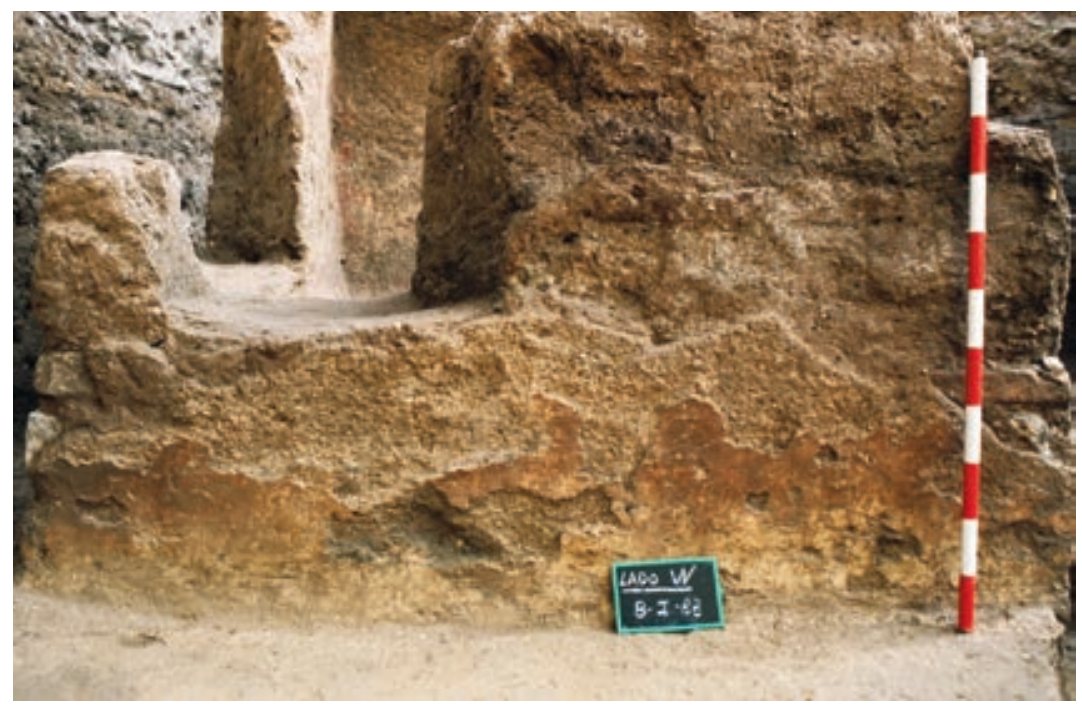

5. Fachada occidental con restos de pintura.

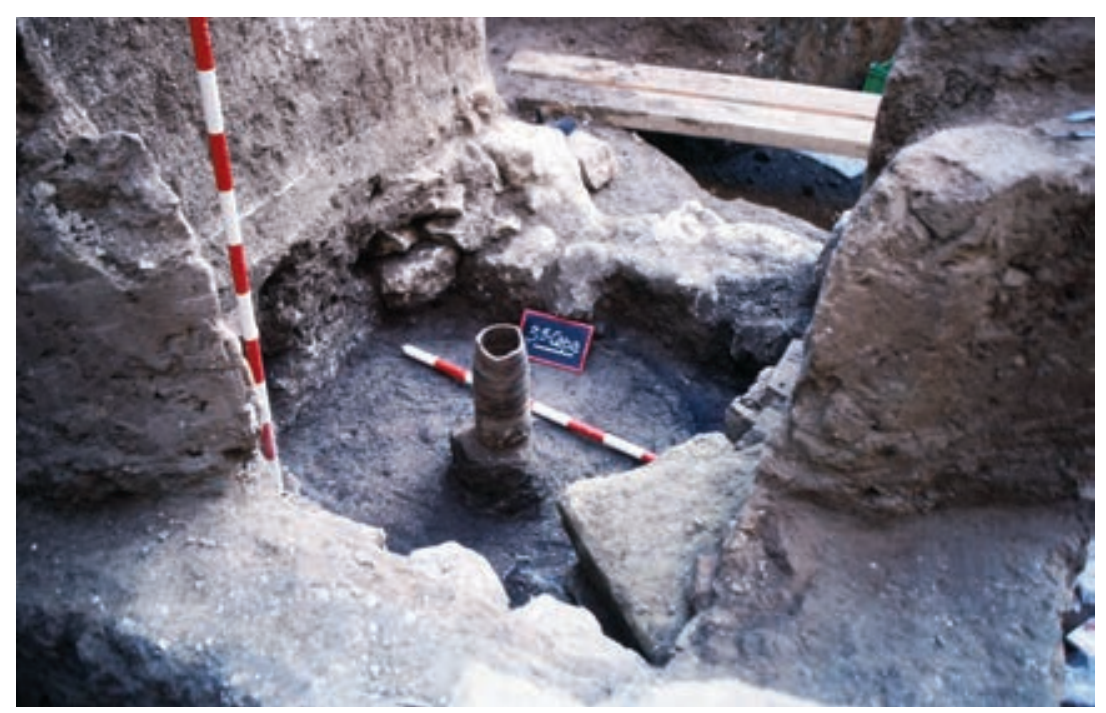

6. Fase de excavación del bustum. 


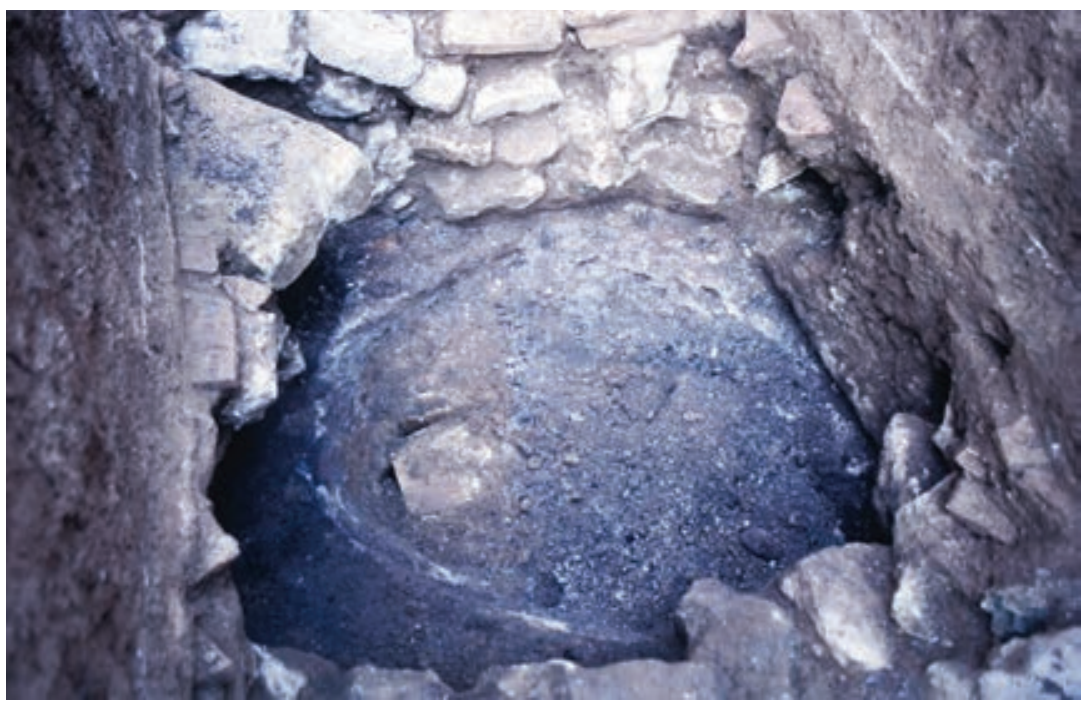

7. Hallazgo de la tapadera de la urna en el bustum.

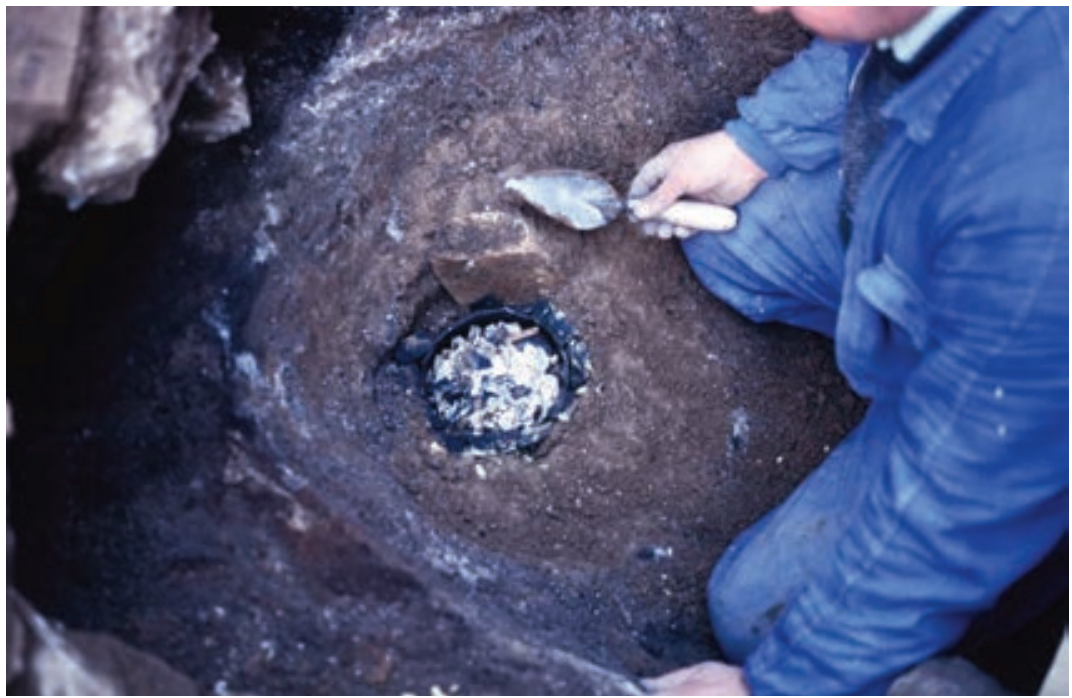

8. Apertura de la urna. 


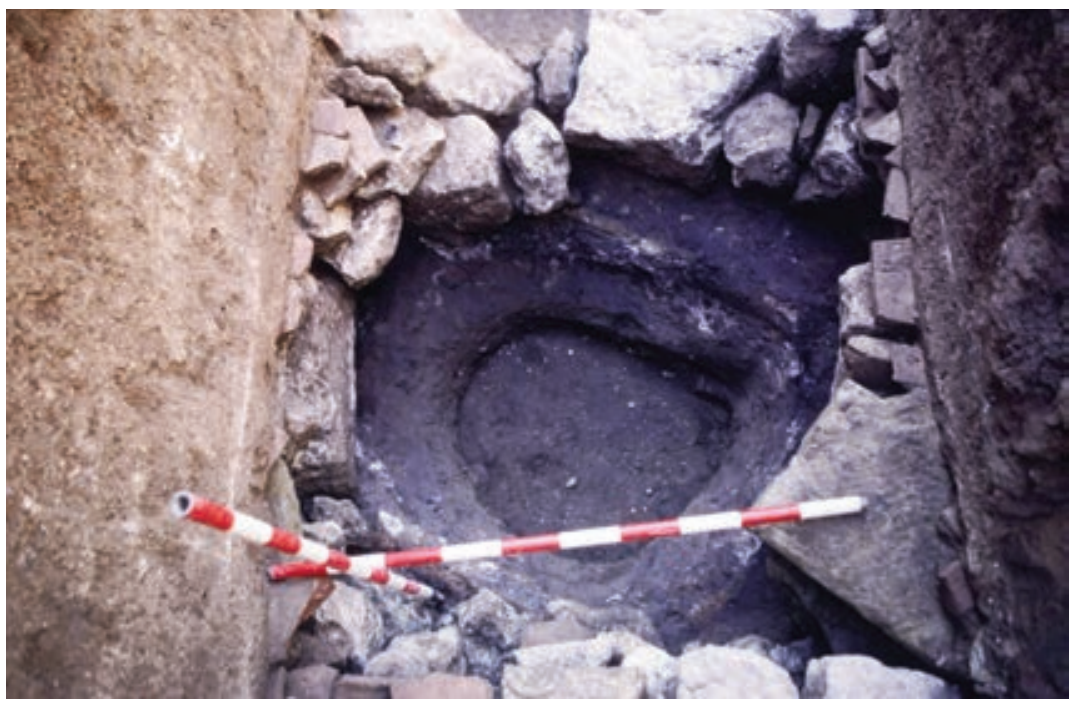

9. Pozo cinerario.

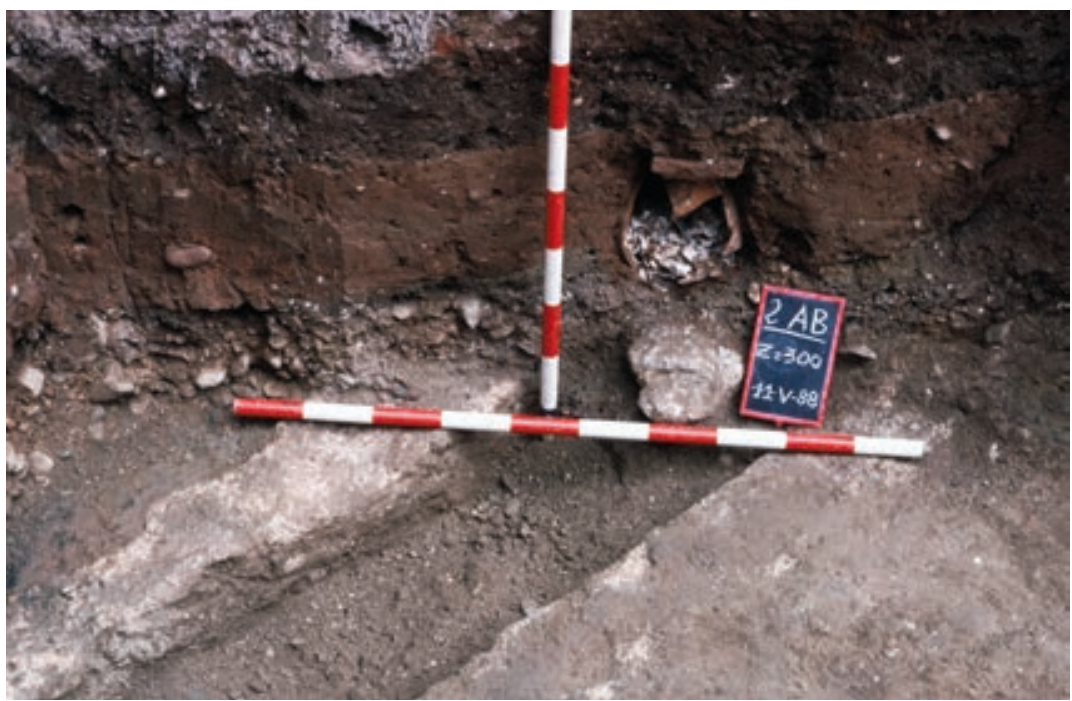

10. Incineración II sobre un canal doméstico anulado. 


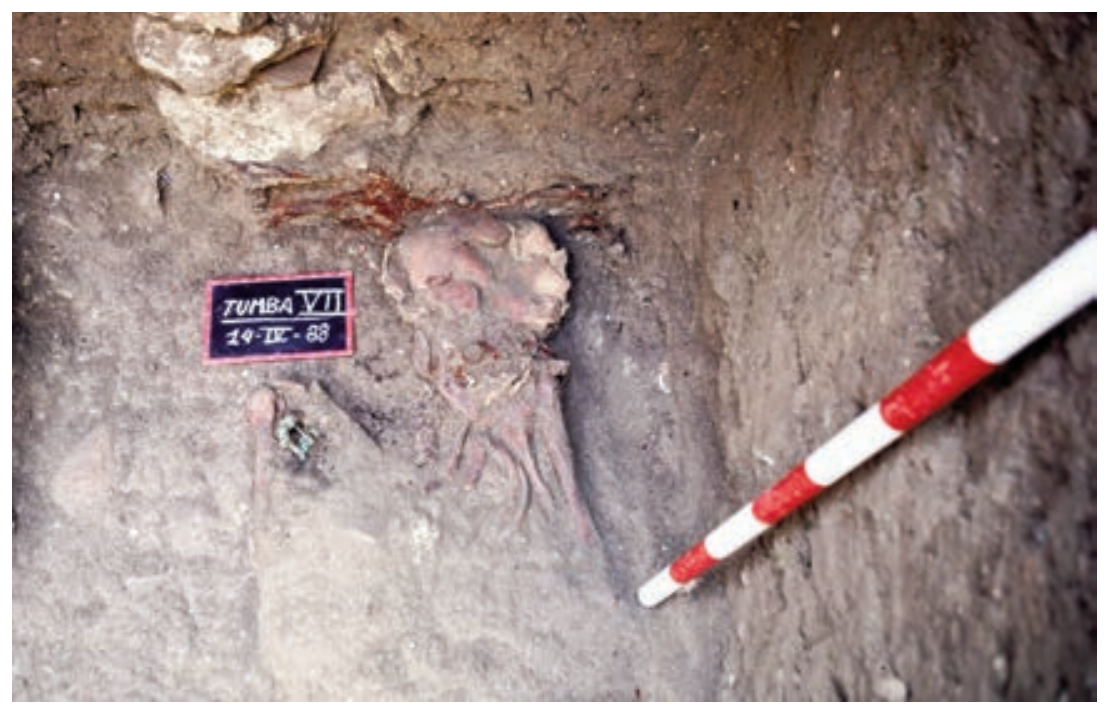

11. Inhumación con fíbula en el hombro derecho (Tumba VII).

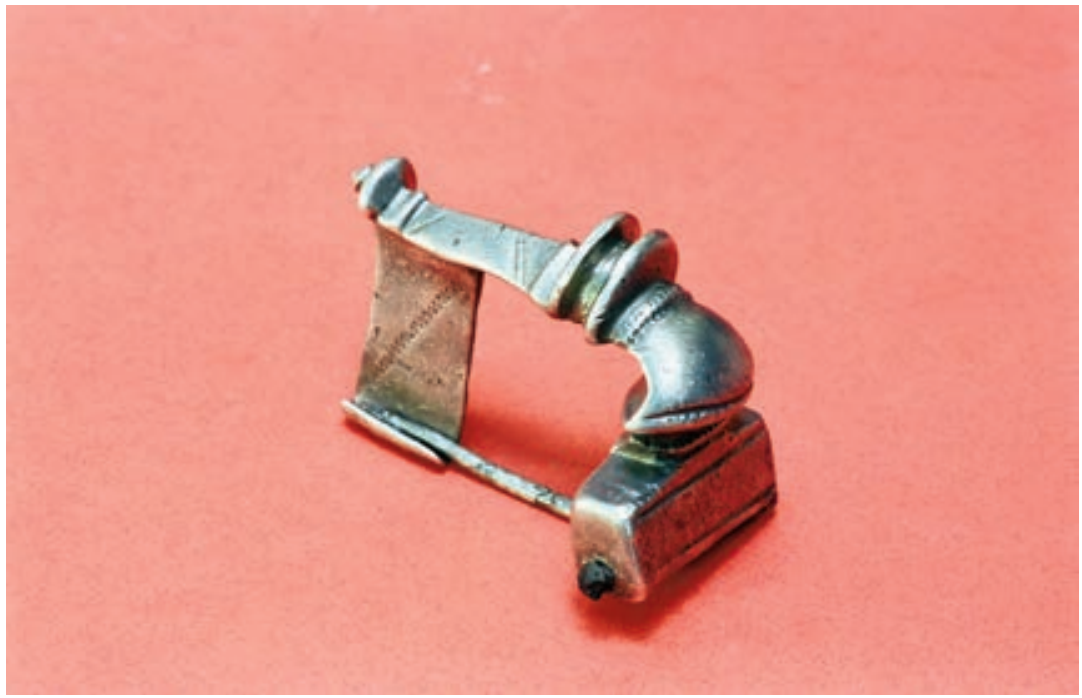

12. La fíbula de plata. 


\section{ANEXO \\ ESTUDIO ANTROPOLÓGICO \\ DE RESTOS ÓSEOS}

Autores:

Salvador Baena Pinilla

Jesús Ángel Obón

José Luis Nieto Amada 


\section{Antecedentes}

Estudio antropológico de restos óseos procedentes de la excavación de 1988 de la c/ Predicadores de Zaragoza de cronología romana (Caesaraugusta SII). Se nos facilitan en cajas individualizadas de cartón identificadas con número de tumba y caja.

En total se estudian 12 tumbas y los restos óseos incinerados de un bustum.

El estudio se desarrolla durante el año 2006.

\section{Relación de operaciones practicadas}

1) Inventario de los restos: se realiza de acuerdo con la codificación según estándar habitual:
1. presente completo
2. presente fragmentado
3. ausente (postmortem)
4. pérdida antemortem
5. dentición sin erupcionar
6. ausencia congénita

2) Estudio antroposcópico y odontoscópico.

3) Estudio antropométrico y odontométrico.

4) Fotografías de hallazgos de interés antropológico.

5) Radiografías de piezas de interés.

Diagnóstico del dimorfismo sexual-género

Diagnóstico de la edad al morir

Diagnóstico de la talla

Hallazgos de interés antropológico

Marcadores de estrés

Paleopatología

A continuación pasaremos al estudio individualizado de cada una de las tumbas según los ítems referidos con anterioridad 


\section{TUMBA-I}

\section{Inventario}

INVENTARIO ESQ. CRANEAL

\begin{tabular}{|c|c|c|c|}
\hline \multicolumn{5}{|c|}{ Tumba I } \\
\hline Hueso & dcho. & impar & izdo. \\
\hline Frontal & & 2 & \\
Parietal & 2 & & 1 \\
Occipital & & 2 & \\
Temporal & 2 & & 2 \\
Zigomático & 3 & & 3 \\
Palatino & 3 & & 3 \\
Maxil. sup. & 2 & & 3 \\
Nasal & 3 & & 3 \\
Etmoides & & 3 & \\
Lacrimal & 3 & & 3 \\
Vómer & & 3 & \\
Esfenoides & & 3 & \\
M. cuerpo & 2 & & 2 \\
M. rama & 2 & & 2 \\
\hline
\end{tabular}

INVENTARIO DENTAL

\begin{tabular}{|c|c|c|c|}
\hline \multicolumn{4}{|c|}{ Tumba I FÓRMULA F. D. I. } \\
\hline \multicolumn{4}{|c|}{ maxilar } \\
\hline pieza & dcho. & pieza & $i z d o$. \\
\hline 51 & 1 & 61 & 1 \\
\hline 52 & 3 & 62 & 1 \\
\hline 53 & 1 & 63 & 1 \\
\hline 54 & 1 & 64 & 3 \\
\hline 55 & 1 & 65 & 1 \\
\hline ger. 16 & 1 & ger. 26 & 1 \\
\hline \multicolumn{4}{|c|}{ mandíbula } \\
\hline pieza & dcho. & pieza & $i z d o$. \\
\hline 81 & 1 & 71 & 1 \\
\hline 82 & 1 & 72 & 1 \\
\hline 83 & 1 & 73 & 1 \\
\hline 84 & 1 & 74 & 1 \\
\hline 85 & 1 & 75 & 1 \\
\hline ger. 43 & 1 & 31 & 1 \\
\hline ger. 46 & 1 & ger. 32 & 1 \\
\hline & & ger. 33 & 1 \\
\hline
\end{tabular}

INVENTARIO ESQ. POSCRANEAL

\begin{tabular}{|c|c|c|c|}
\hline \multicolumn{4}{|c|}{ Tumba } \\
\hline Hueso & dcho. & impar & izdo. \\
\hline Hioides & & 3 & \\
Clavícula & 3 & & 3 \\
Omoplato & 3 & & 2 \\
Húmero & 2 & & 2 \\
Radio & 2 & & 2 \\
Cúbito & 2 & & 2 \\
Mano & 2 & & 2 \\
M. esternal & & 2 & \\
Mesoesternón & & 2 & \\
Costillas & & 2 & \\
Atlas & & 3 & \\
Axis & & 3 & \\
C. 3 a 7 & & 2 & \\
D. 1 a 12 & & 2 & \\
L. 1 a 5 & & 2 & \\
Sacro & & 2 & \\
Ilión & 1 & & 1 \\
Pubis & 1 & & 1 \\
Isquión & 1 & & 1 \\
Fémur & 2 & & 2 \\
Rótula & 3 & & 3 \\
Tibia & 2 & & 2 \\
Peroné & 2 & & 2 \\
Calcáneo & 3 & & 3 \\
Astrágalo & 3 & & 3 \\
Pie & 2 & & 2 \\
\hline
\end{tabular}




\section{Antropometría}

La biometría se ajusta al estado de los restos y se prioriza el lado izquierdo sobre el derecho.

\begin{tabular}{|c|c|c|}
\hline \multicolumn{3}{|c|}{ Tumba I } \\
\hline Hueso & Medida & $\mathrm{mm}$ \\
\hline Húmero & Long. diáfisis & 111,00 \\
Cúbito & Long. diáfisis & 96,00 \\
Radio & Long. diáfisis & 86,00 \\
Fémur & Long. diáfisis & 143,00 \\
Peroné & Long. diáfisis & 84,00 \\
Tibia & Long. diáfisis & 114,00 \\
\hline
\end{tabular}

\section{Odontometría}

\begin{tabular}{|c|c|c|c|c|c|c|c|c|c|c|c|c|c|}
\hline Tumba I & suelto & suelto & suelto & suelto & suelto & suelto & suelto & suelto & suelto & suelto & suelto & suelto & suelto \\
\hline Identificación & 588 & 589 & 590 & 591 & 592 & 593 & 594 & 595 & 596 & 597 & 598 & 599 & 600 \\
Número de diente & 73 & 51 & 61 & 72 & 62 & 53 & 83 & 71 & 82 & 81 & 74 & 54 & 65 \\
Diámetro m-d (mm) & 5,00 & 6,15 & 6,00 & 4,40 & 5,00 & 6,35 & 5,50 & 3,95 & 4,40 & 3,70 & 7,40 & 6,60 & 8,10 \\
Diámetro v-l (mm) & 4,70 & 5,00 & 4,80 & 3,60 & 4,05 & 5,55 & 4,90 & 3,50 & 3,70 & 3,30 & 6,60 & 8,20 & 9,20 \\
Número de cúspides & & & & & & & & & & & 4 & 3 & 4 \\
Características 1 & & & & & & & & & & & T. ZU & T. ZU & T. CAR \\
Características 2 & & & & & & & & & & & Cr TR. & & Cr TR. \\
Anomalías & & & & & & & & & & & & & \\
\hline
\end{tabular}

\begin{tabular}{|c|c|c|c|c|c|c|c|c|c|c|c|c|}
\hline Tumba I & & suelto & suelto & suelto & suelto & suelto & & & & & suelto & suelto \\
\hline Identificación & 601 & 602 & 603 & 604 & 605 & 606 & 573 & 573 & 573 & 575 & S/ID & $605 ?$ \\
Número de diente & $\mathrm{G} 46$ & $\mathrm{G} 26$ & 55 & $\mathrm{G} 16$ & 63 & $\mathrm{G} 32$ & 84 & 85 & $\mathrm{G} 43$ & 75 & 31 & $\mathrm{G} 33$ \\
Diámetro m-d (mm) & 11,00 & 10,80 & 8,70 & 10,90 & 6,40 & 5,30 & 7,30 & 9,70 & 6,00 & 9,80 & 4,70 & \\
Diámetro v-1 (mm) & 9,60 & 10,80 & 9,50 & 10,90 & 5,50 & 4,10 & 6,40 & 8,00 & 3,80 & 8,40 & 4,20 & \\
Número de cúspides & 5 & 4 & 4 & 4 & & & 4 & 5 & & 5 & & \\
Características 1 & & & T. CAR & T. CAR & & & & & & & & \\
Características 2 & & Cr TR. & Cr TR. & Cr TR. & & & & & & & & \\
Anomalías & & & & & & & & & & & & \\
\hline
\end{tabular}

\section{Antroposcopia}

Se trata de unos restos esqueléticos, limpios, de reducido tamaño en el que faltan de fusionar las epífisis a las diáfisis en todos los huesos largos, tampoco están fusionadas las vértebras. Se aprecian en la valoración odon- 
toscópica la presencia de dientes caducos con gérmenes en formación de los dientes permanentes. Se encontraron 2 tubérculos de Carabelli en los gérmenes dentarios de las piezas 16 y 26 de la Tumba I así como en las piezas 55 y 65 por su correspondencia anatómica con los primeros molares permanentes.

\section{Estudio radiológico}

Se realiza estudio de radiografías de los restos mandibulares y dentales con la finalidad de evidenciar los gérmenes dentales y su estado, así como el estado de la raíces y de los alvéolos.

\section{Diagnóstico del sexo}

El diagnóstico de los patrones de dimorfismo sexual en sujetos infantiles es complejo; fundamentalmente nos basamos en el estudio de la morfología mandibular, de la morfología del hueso ilíaco y de las características odontológicas.

En la mandíbula evidenciamos:

- Pronunciamiento del mentón: el mentón es más prominente.

- Forma del arco dental anterior: el arco dental anterior es más ancho; los alvéolos caninos sobresalen con relación a los molares adyacentes, adquiriendo una forma en U.

- Eversión de la región goniaca: el ángulo es evertido, ligeramente sobresaliente.

En el ileón comprobamos:

- El ángulo de la escotadura ciática es más angosta y se acerca a los 90.

- La profundidad de la escotadura ciática mayor es profunda.

- El criterio del arco: continúa el borde lateral de la superficie auricular.

- Curvatura de la cresta ilíaca es más pronunciada, delineando una $S$ marcada.

Estos patrones estudiados son claramente orientadores de género masculino. 
Diagnóstico de la edad

Por el simple estudio antroposcópico y odontoscópico podemos afirmar que se trata de un individuo en etapas infantiles, no existe fusión epifisaria y, por tanto, en estos casos el método más apropiado para determinar la edad es la evolución de la dentición tanto con la erupción y grado de mineralización como con la valoración de los gérmenes dentarios y asociado al estudio radiológico. El esquema de Ubelaker que muestra las secuencias de formación y erupción dental es una técnica ajustada. Si valoramos el estado de los dientes según esta tabla, podríamos ajustar la edad entorno a los 2 años $+/-8$ meses.

Unimos a esta valoración el hallazgo de la falta de fusión entre los arcos y el cuerpo vertebral (estadio «a» de Steele y Bramblett) que sitúa entre 2 y 4 años según Krogman e Iscan.

Diagnóstico de la talla

Debido a la falta de fusión ósea es difícil determinar con exactitud una talla, pero basándonos en la longitud de la diáfisis según la tabla de Oliviery Pineau, podríamos establecer

Talla: 7,92 x long. del húmero $+0,32+/-1,8=88,23+/-1,8 \mathrm{~cm}$.

Talla: $7,39 \mathrm{x}$ long. de la tibia $-3,55+/-1,92=80,7+/-1,92 \mathrm{~cm}$.

\section{Hallazgos paleopatológicos}

Lo único característico hallado son los tubérculos de Carabelli en los primeros molares permanentes superiores y en los segundos molares temporales superiores.

Asimismo, se detectó la presencia del tubérculo de Zückerkandl a nivel gingival de la cara mesio-vestibular de los primeros molares temporales tanto superiores como inferiores.

No hay caries. 


\section{TUMBA-III}

\section{Inventario}

INVENTARIO DENTAL

\begin{tabular}{|c|c|c|c|}
\hline \multicolumn{4}{|c|}{ Tumba III FÓRMULA F. D. I. } \\
\hline \multicolumn{4}{|c|}{ maxilar } \\
\hline pieza & dcho. & pieza & $i z d o$. \\
\hline 11 & 3 & 21 & 3 \\
\hline 12 & 3 & 22 & 3 \\
\hline 13 & 3 & 23 & 1 \\
\hline 14 & 3 & 24 & 1 \\
\hline 15 & 3 & 25 & 2 \\
\hline 16 & 1 & 26 & 3 \\
\hline 17 & 1 & 27 & 3 \\
\hline 18 & 3 & 28 & 1 \\
\hline \multicolumn{4}{|c|}{ mandíbula } \\
\hline pieza & dcho. & pieza & $i z d o$. \\
\hline 41 & 3 & 31 & 3 \\
\hline 42 & 3 & 32 & 3 \\
\hline 43 & 3 & 33 & 2 \\
\hline 44 & 1 & 34 & 2 \\
\hline 45 & 1 & 35 & 1 \\
\hline 46 & 1 & 36 & 1 \\
\hline 47 & 2 & 37 & 1 \\
\hline 48 & 1 & 38 & 1 \\
\hline
\end{tabular}

INVENTARIO ESQ. CRANEAL

\begin{tabular}{|c|c|c|c|}
\hline \multicolumn{5}{|c|}{ Tumba III } \\
\hline Hueso & dcho. & impar & izdo. \\
\hline Frontal & & 2 & \\
Parietal & 2 & & 2 \\
Occipital & & 2 & \\
Temporal & 2 & & 2 \\
Zigomático & 2 & & 3 \\
Palatino & 2 & & 2 \\
Maxil. Sup. & 2 & & 2 \\
Nasal & 3 & & 3 \\
Etmoides & & 3 & \\
Lacrimal & 3 & & 3 \\
Vómer & 3 & & 3 \\
Esfenoides & & 3 & \\
M. Cuerpo & 2 & & 2 \\
M. Rama & 2 & & 2 \\
\hline
\end{tabular}

INVENTARIO ESQ. POSCRANEAL

\begin{tabular}{|c|c|c|c|}
\hline \multicolumn{4}{|c|}{ Tumba III } \\
\hline Hueso & dcho. & impar & $i z d o$. \\
\hline Hioides & & 3 & \\
Clavícula & 3 & & 3 \\
Omoplato & 3 & & 3 \\
Húmero & 2 & & 2 \\
Radio & 2 & & 2 \\
Cúbito & 2 & & 2 \\
Mano & 2 & & 2 \\
M. esternal & & 3 & \\
Mesoesternón & & 3 & \\
Costillas & 2 & & 2 \\
Atlas & & 3 & \\
Axis & & 3 & \\
C. 3 a 7 & & 3 & \\
D. 1 a 12 & & 3 & \\
L. 1 a 5 & & 3 & \\
Sacro & & 2 & \\
Ilión & 3 & & 3 \\
Pubis & 3 & & 3 \\
Isquión & 3 & & 3 \\
Fémur & 3 & & 3 \\
Rótula & 2 & & 3 \\
Tibia & 3 & & 3 \\
Peroné & 1 & & 3 \\
Calcáneo & 1 & & 3 \\
Astrágalo & 1 & & 3 \\
Pie & 2 & & 2 \\
\hline
\end{tabular}




\section{Antropometría}

La biometría se ajusta al estado de los restos y se prioriza el lado izquierdo sobre el derecho.

RADIO: TUMBA III

\begin{tabular}{|c|l|r|}
\hline $\begin{array}{c}\text { Hemilado } \\
\text { izdo. }\end{array}$ & \multicolumn{1}{|c|}{ Medida } & $\mathrm{mm}$ \\
\hline \multirow{6}{*}{} & Long. máx. estimada & 245,00 \\
& Long. fisiol. estimada & 236,00 \\
& Perímetro mín. & 48,00 \\
& Perímetro mitad & 52,00 \\
& Perímetro cabeza estimada & 72,00 \\
& Diámetro máx. cabeza & 21,00 \\
& Diámetro mín. cabeza & 19,00 \\
& Perímetro tuber. delt. estimada & 52,00 \\
& Diámetro trans. tuber. delt. & \\
& Diámetro trans mitad & 11,00 \\
& Diámetro ant.post mitad & 8,00 \\
& Anch. epif. distal. & 26,00 \\
\hline & \multicolumn{1}{|c|}{ Índices } & \\
\hline & Robustez & 19,59 \\
& Diafisario & 72,73 \\
\hline
\end{tabular}

CÚBITO: TUMBA III

\begin{tabular}{|l|l|r|}
\hline $\begin{array}{c}\text { Hemilado } \\
\text { izdo. }\end{array}$ & \multicolumn{1}{|c|}{ Medida } & $\mathrm{mm}$ \\
\hline \multirow{7}{*}{} & Long. máx. & 266,00 \\
& Long. fisiol. & 260,00 \\
& Perímetro min. & 48,00 \\
& Perímetro mitad & 53,00 \\
& Perímetro cabeza & 14,00 \\
& Diámetro máx. mitad & 14,00 \\
& Diámetro mín. mitad & 9,00 \\
& Diámetro transverso subsigmoideo & 19,00 \\
& Anchu. epífisis distal. & 17,00 \\
& Altura coronoides & 31,00 \\
\hline & & \\
\hline & Indices & 3,38 \\
& Plabustez & 64,29 \\
\hline
\end{tabular}

RÓTULA: TUMBA III

\begin{tabular}{|l|c|c|}
\hline Hemilado dcho. & Medida & $\mathrm{mm}$ \\
\hline & Alt. máx. & 44,00 \\
& Anch. máx. & 39,00 \\
& Espesor máx. & 16,00 \\
\hline & \multicolumn{2}{|c|}{ Índices } \\
\hline & Rotuliano & 112,82 \\
\hline
\end{tabular}

CALCÁNEO: TUMBA III

\begin{tabular}{|l|c|c|}
\hline Hemilado dcho. & Medida & $\mathrm{mm}$ \\
\hline & Long. máx. & 71,00 \\
& Anch. máx. & 41,00 \\
\hline & \multicolumn{2}{|c|}{ Índices } \\
\hline & Anchura & 57,75 \\
\hline
\end{tabular}

PERONÉ: TUMBA III

\begin{tabular}{|l|l|r|}
\hline $\begin{array}{c}\text { Hemilado } \\
\text { izdo. }\end{array}$ & \multicolumn{1}{|c|}{ Medida } & $\mathrm{mm}$ \\
\hline \multirow{1}{*}{} & Long. máx. & 355,00 \\
& Perímetro mín. & 46,00 \\
& Perímetro mitad & 53,00 \\
& Diámetro máx. mitad & 12,00 \\
& Diámeto mín. mitad & 11,00 \\
& Anch. epif. distal. & 21,00 \\
\hline & \multicolumn{1}{|c|}{ Indices } & \\
\hline & Robustez & 14,93 \\
& Diáfisis & 91,67 \\
\hline
\end{tabular}




\begin{tabular}{|c|c|c|c|c|c|c|c|c|c|c|c|c|c|c|c|c|c|c|c|}
\hline$\vec{\Xi}$ & $\triangle$ & $\substack{\infty \\
\infty}^{\infty}$ & 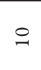 & 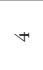 & & & $\begin{array}{l}\dot{y} \\
\text { M } \\
\text { Mn }\end{array}$ & 岁 & & + & & $\stackrel{+}{\sim}$ & & $\sim$ & & - & & & \\
\hline 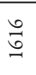 & 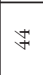 & 3 & $\sigma_{0}^{0}$ & $N$ & $\begin{array}{l}\dot{\tilde{g}} \\
\dot{u}\end{array}$ & & $\begin{array}{l} \\
\text { ü } \\
\text { 㟔 }\end{array}$ & & & $\stackrel{\stackrel{+}{*}}{ }$ & & $\stackrel{+}{\sim}$ & & $\sim$ & & - & & & \\
\hline$\stackrel{n}{\underline{G}}$ & $\stackrel{\circ}{2}$ & ڤ̊ & $\begin{array}{l}\infty \\
\stackrel{\infty}{\circ}\end{array}$ & 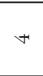 & $\begin{array}{l}\dot{S} \\
ن \\
\forall\end{array}$ & & 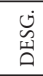 & & & + & & $m$ & & N & & - & & & \\
\hline$\underset{\vec{G}}{\stackrel{+}{*}}$ & 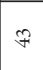 & ț & $\approx$ & & & & 晏 & & & $\because$ & & & & & & - & & & \\
\hline$\vec{G}$ & $\tilde{\sim}$ & $\Re$ & $\stackrel{n}{n}$ & & & & 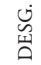 & & & + & & $\stackrel{+}{\sim}$ & & $\sim$ & & - & & & \\
\hline$\underset{-}{\simeq}$ & $\stackrel{\infty}{\sim}$ & $\infty$ & $\hat{\varrho}$ & $n$ & & & & & & + & & & & & & & & & \\
\hline こิ & $\stackrel{\imath}{\hat{y}}$ & & & & & & 峜 & & & & & & & & & & & & \\
\hline & $\begin{array}{l}\widetilde{2} \\
\tilde{B}\end{array}$ & & & & & & 岁 & & & & & & & & & $\approx$ & & & \\
\hline & $\stackrel{m}{\xi}$ & & & & & & 峜 & & & & & & & & & & & & \\
\hline & $\infty$ & ㅇ & $\hat{\infty}$ & in & & & $\begin{array}{l}\text { un } \\
\text { 虫 }\end{array}$ & & & + & in & $\sim$ & & $N$ & N & - & & & \\
\hline & के & $\stackrel{\circ}{\sigma}$ & $a$ & t & & & 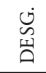 & & & + & 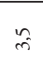 & $\dot{m}$ & & $N$ & N & - & - & & - \\
\hline & in & $\cong$ & $\stackrel{\circ}{\circ}$ & in & & & $\begin{array}{l}\text { ú } \\
\text { 㟔 }\end{array}$ & & & + & $n$ & $\stackrel{+}{m}$ & & $\sim$ & - & $N$ & - & & \\
\hline & $m$ & $\mathbb{S}^{+}$ & $n$ & $N$ & & & 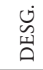 & & & + & $N$ & $\underset{+}{+}$ & & $N$ & - & - & - & & - \\
\hline & 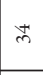 & th $^{+}$ & $\vec{b}^{\circ}$ & $N$ & $\begin{array}{l}\tilde{F} \\
\dot{u}\end{array}$ & & $\begin{array}{l}\dot{y} \\
\text { 出 } \\
\text { 足 }\end{array}$ & & & + & $N$ & $\stackrel{+}{\sim}$ & & $\mathrm{N}$ & - & - & & & \\
\hline $\begin{array}{l}\stackrel{0}{ } \\
\stackrel{2}{\simeq}\end{array}$ & $\underset{+}{\stackrel{\infty}{+}}$ & $\overrightarrow{0}$ & $a$ & in & & & $\begin{array}{l}\vec{m} \\
\dot{m}\end{array}$ & & & & & & & & & & & & \\
\hline $\begin{array}{l}\mathscr{D} \\
\stackrel{\sim}{\sim}\end{array}$ & $\underset{f}{\text { ff }}$ & & & & & & 峜 & & & & & & & & & & - & & \\
\hline $\begin{array}{l}\mathscr{D} \\
ٌ \\
ٌ\end{array}$ & 난 & $\stackrel{\cong}{\exists}$ & $\approx$ & in & & & 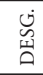 & & & + & $N$ & $\stackrel{+}{m}$ & & $\sim$ & - & $N$ & - & & \\
\hline ஜ & $\nLeftarrow$ & $\tilde{\sigma}$ & r & $N$ & & & $\begin{array}{l}\text { U. } \\
\text { 出 } \\
\text { D. }\end{array}$ & & & + & $N$ & $\stackrel{+}{\sim}$ & & $\sim$ & - & - & - & & \\
\hline 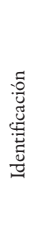 & 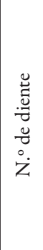 & 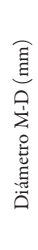 & 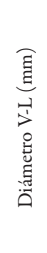 & $\begin{array}{l}\tilde{y} \\
\bar{n} \\
\bar{z} \\
\tilde{z} \\
y \\
\dot{z} \\
\dot{z}\end{array}$ & 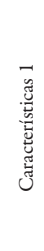 & 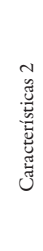 & 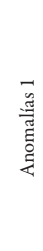 & 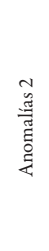 & 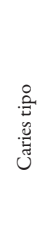 & $\frac{0}{\frac{0}{\tilde{n}}}$ & 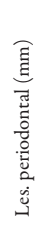 & 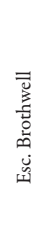 & 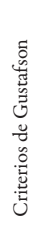 & 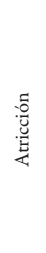 & 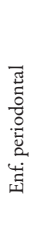 & 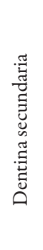 & 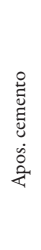 & 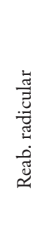 & 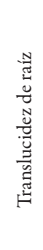 \\
\hline
\end{tabular}




\section{Antroposcopia}

Se trata de unos restos óseos limpios, fragmentados e incompletos en muchos casos, la osificación es completa. Los restos están consolidados artificialmente.

\section{Estudio radiológico}

Se realiza estudio radiológico mediante chasis y placas mamográficas por su nitidez para evidenciar el sacro, los metatarsianos y el calcáneo con finalidad de estudio paleopatológico.

Se realizan radiografías periapicales de las piezas dentales de interés.

\section{Diagnóstico del sexo}

El diagnóstico se realiza con los datos tanto del esqueleto craneal como poscraneal.

A nivel craneal se aprecia un reborde orbitario grueso, romo y marcado con un frontal inclinado (codificado con 5 según los estándares Buikstra y Ubelaker) Se puede evidenciar también los restos de la apófisis mastoides esta es gruesa y prominente (codificada como 5 según los estándares Buikstra y Ubelaker).

En la morfología mandibular se puede observar una rama ascendente ancha, robusta, con marcados relieves óseos y eversion de la aleta goníaca, se aprecia también un mentón cuadrangular ancho y marcado (código 5 según los estándares Buikstra y Ubelaker).

En el sacro podemos destacar como principal hallazgo las características morfológicas con un sacro largo y excavado con una carilla auricular también larga; no se aprecia surco preauricular.

En los huesos largos, además de su robustez de carácter inespecífico, sí podemos aportar las medidas de radio mayor de $245 \mathrm{~mm}$ de longitud máxima, cúbito mayor de $266 \mathrm{~mm}$ y peroné de $355 \mathrm{~mm}$.

Los variaciones morfológicas craneales, mandibulares, del sacro y las dimensiones de los huesos largos son claramente orientadores del sexo masculino. 


\section{Diagnóstico de la edad}

La determinación de la edad se realiza por distintos métodos, pero en la actualidad el método reconocido y estandarizado es el estudio morfológico de la metamorfosis que sufre con la evolución de la edad la unión de la cuarta costilla con la unión condral, valorado este método encontramos una carilla articular profunda en forma de «U» y el reborde presenta irregularidades, una carilla compatible con fase 3 según Iscan-Loth comparando con moldes estandarizados, equivalente a una edad estimada de 24-28 años. Acrecientan esta aproximación etaria otra serie de hallazgos como son la presencia de restos suturales a nivel craneal abiertos o parcialmente abiertos, falta de desgaste dental en molares posteriores, así como ausencia de signos degenerativos con osificación completa, todos ellos compatibles con un adulto joven.

\section{Diagnóstico de la talla}

Valorando la longitud de los huesos largos medidos podemos estimar un rango de la estatura; para ello recordamos las medidas:

- Longitud estimada del radio: $245 \mathrm{~mm}$.

- Longitud del cúbito: $266 \mathrm{~mm}$.

- Longitud del peroné: $355 \mathrm{~mm}$.

Valorando algunas de las tablas habituales podemos estimar:

- Tabla de Manouvrier:

- Por la estimación con el radio: talla $166 \mathrm{~cm}$ a $168 \mathrm{~cm}$.

- Por la estimación con el cúbito: talla $166 \mathrm{~cm}$ a $168 \mathrm{~cm}$.

- Por la estimación con el peroné: talla $164 \mathrm{~cm}$ a $165 \mathrm{~cm}$.

- Tabla de Krogman:

- Por la estimación con el radio: talla $171,6 \mathrm{~cm}+/-4,3$.

- Por la estimación con el cúbito: talla $172 \mathrm{~cm}+/-4,3$.

- Por la estimación con el peroné: talla $167 \mathrm{~cm}+/-3.2$.

- Tabla de Telkka:

- Por la estimación con el radio: talla $175 \mathrm{~cm}+/-5$.

- Por la estimación con el cúbito: talla $180 \mathrm{~cm}+/-5,2$.

- Por la estimación con el peroné: talla $168 \mathrm{~cm}+/-4,4$.

Se podría estimar una talla, valorando todos los datos, de 160 a $170 \mathrm{~cm}$. 


\section{Hallazgos de interés paleopatológico}

1. Marcadores de estrés óseo a nivel de la cara anterior de la rótula y a nivel de la cara posterior del calcáneo por la impronta del tendón rotuliano y del tendón de Aquiles. Estos hallazgos son valorados según los criterios de Hawkey y Merbs (1995) con el grado 3 por las excrecencias insercionales a nivel del calcáneo (mayores de 5 $\mathrm{mm}$ ) y grado 2 (de 2 a $5 \mathrm{~mm}$ ) en la rótula.

2. Fracturas de estrés en metatarsiano: en la epífisis distal de algunos metatarsianos se aprecian signos propios de microfracturas de estrés; estas se evidencian en la realización de placas mamográficas.

3. En la cara posterior del sacro se aprecia un defecto de osificación en la línea media (disrafismo) por falta de fusión, patología de carácter congénito. Esta patología alcanza el nivel más alto de los agujeros sacros posteriores.

4. Aquí nos encontramos con un importante grado de desgaste dental en todas las piezas conservadas (grados 2 + a 3 en la escala de Brothwell) con sus consecuencias como van a ser el comienzo de una enfermedad periodontal, la presencia de fenestraciones, la aparición de dentina secundaria y el incremento de aposición de cemento radicular. Hay presencia de sarro. Se aprecia una malposición de la pieza 48 que se encuentra mesializada. 


\section{TUMBA-IV}

\section{Inventario}

ESQUELETO CRANEAL

\begin{tabular}{|c|c|c|c|}
\hline \multicolumn{4}{|c|}{ Tumba IV } \\
\hline Hueso & dcho. & impar & $i z d o$. \\
\hline Frontal & & 2 & \\
Parietal & 2 & & 2 \\
Occipital & & 2 & \\
Temporal & 3 & & 3 \\
Zigomático & 2 & & 3 \\
Palatino & 2 & & 2 \\
Maxil. sup. & 2 & & 2 \\
Nasal & 3 & & 3 \\
Etmoides & & 3 & \\
Lacrimal & 3 & & 3 \\
Vómer & & 3 & \\
Esfenoides & & 3 & \\
M. cuerpo & 2 & & 2 \\
M. rama & 2 & & 2 \\
\hline
\end{tabular}

INVENTARIO DENTAL

\begin{tabular}{|c|c|c|c|}
\hline \multicolumn{4}{|c|}{ Tumba IV FÓRMULA F. D. I. } \\
\hline \multicolumn{4}{|c|}{ maxilar } \\
\hline pieza & dcho. & pieza & $i z d o$. \\
\hline 11 & 1 & 21 & 1 \\
\hline 12 & 1 & 22 & 1 \\
\hline 13 & 1 & 23 & 1 \\
\hline 14 & 1 & 24 & 2 \\
\hline 15 & 1 & 25 & 2 \\
\hline 16 & 1 & 26 & 3 \\
\hline 17 & 3 & 27 & 3 \\
\hline 18 & 3 & 28 & 3 \\
\hline \multicolumn{4}{|c|}{ mandíbula } \\
\hline pieza & dcho. & pieza & $i z d o$. \\
\hline 41 & 1 & 31 & 1 \\
\hline 42 & 1 & 32 & 1 \\
\hline 43 & 1 & 33 & 3 \\
\hline 44 & 3 & 34 & 3 \\
\hline 45 & 1 & 35 & 3 \\
\hline 46 & 1 & 36 & 2 \\
\hline 47 & 1 & 37 & 3 \\
\hline 48 & 4 & 38 & 3 \\
\hline
\end{tabular}

INVENTARIO POSCRANEAL

\begin{tabular}{|c|c|c|c|}
\hline \multicolumn{4}{|c|}{ Tumba IV } \\
\hline Hueso & dcho. & impar & izdo. \\
\hline Hioides & & 3 & \\
Clavícula & 1 & & 2 \\
Omoplato & 2 & & 2 \\
Húmero & 1 & & 2 \\
Radio & 1 & & 2 \\
Cúbito & 2 & & 2 \\
Mano & 2 & & 2 \\
M. esternal & & 2 & \\
Mesoesternón & & 2 & \\
Costillas & 2 & & 2 \\
Atlas & & 3 & \\
Axis & & 3 & \\
C. 3 a 7 & & 2 & \\
D. 1 a 12 & & 2 & \\
L. 1 a 5 & & 2 & \\
Sacro & & 2 & \\
Ilión & 2 & & 2 \\
Pubis & 1 & & 2 \\
Isquión & 2 & & 2 \\
Fémur & 2 & & 2 \\
Rótula & 1 & & 3 \\
Tibia & 2 & & 2 \\
Peroné & 2 & & 2 \\
Calcáneo & 3 & & 3 \\
Astrágalo & 1 & & 2 \\
Pie & 2 & & 2 \\
\hline & & &
\end{tabular}




\section{Antropometría: extremidad superior}

\begin{tabular}{|c|l|r|}
\hline \multicolumn{3}{|c|}{ Clavícula: Tumba IV } \\
\hline Hemilado dcho. & \multicolumn{1}{|c|}{ Medida } & mm. \\
\hline & Long. máx. & 160,00 \\
& Perímetro cen. & 50,00 \\
& Anch. ext. & 28,00 \\
& Anch. int. & 22,00 \\
\hline & \multicolumn{1}{|c}{ Índices } & \\
\hline & Robustez & 31,25 \\
\hline
\end{tabular}

\begin{tabular}{|c|c|c|}
\hline \multicolumn{3}{|c|}{ Humero: Tumba IV } \\
\hline Hemilado izdo. & Medida & $\mathrm{mm}$. \\
\hline & Long. máx. & 330,00 \\
\hline & Long. fisiol. & 322,00 \\
\hline & Perímetro mín. & 67,00 \\
\hline & Perímetro mitad & 70,00 \\
\hline & Diámetro máx. mitad & 17,00 \\
\hline & Diámetro mín. mitad & 15,00 \\
\hline & Anch. epif. distal. & 60,00 \\
\hline & Diámetro vert. cabeza & 38,00 \\
\hline & Diámetro horizontal cabeza & 44,00 \\
\hline & Anch. sup. art. & 43,00 \\
\hline & Profud. troclea & 20,00 \\
\hline & Diámetro borde lat. troclea & 19,00 \\
\hline & Anch. condilo & 12,00 \\
\hline & Alt. Condilo & 17,00 \\
\hline & Anch. máx. epitroclea. & 25,00 \\
\hline & Diámetro AP. mín. epitroclea & 15,00 \\
\hline & Anch. fosa olecran. & 24,00 \\
\hline & Diámetro bord. ext. fosa olecra. & 22,00 \\
\hline & Diámetro bord. int. fosa olecra. & 17,00 \\
\hline & Anch. cabeza. & 12,00 \\
\hline & Indices & \\
\hline & Robustez & 21,21 \\
\hline & Diafisario & 88,24 \\
\hline
\end{tabular}

\begin{tabular}{|l|l|r|}
\hline \multicolumn{2}{|c|}{ Cúbito: Tumba IV } \\
\hline Hemilado izdo. & \multicolumn{1}{|c|}{ Medida } & \multicolumn{1}{c|}{$\mathrm{mm}$} \\
\hline \multirow{1}{*}{} & Long. máx. & 272,00 \\
& Long. fisiol. & 247,00 \\
& Perímetro mín. & 48,00 \\
& Perímetro mitad & 51,00 \\
& Perímetro cabeza & 14,00 \\
& Diámetro máx. mitad & 16,00 \\
& Diámetro mín. mitad & 9,00 \\
& Diámetro transverso subsigmoideo & 19,00 \\
& Anchu. epifis. distal. & 15,00 \\
& Altura coronoides & 32,00 \\
\hline & \multicolumn{1}{|c|}{ Indices } & 17,64 \\
\hline & Robustez & 56,25 \\
\hline
\end{tabular}




\section{Antropometría: extremidad inferior}

\begin{tabular}{|c|c|c|}
\hline \multicolumn{3}{|c|}{ Fémur: Tumba IV } \\
\hline Hemilado izdo. & Medida & $\mathrm{mm}$ \\
\hline & Long. máx. estimada & 472,00 \\
\hline & Long. fisiol. & 470,00 \\
\hline & Perímetro mitad & 92,00 \\
\hline & Diámetro ap. mitad & 23,00 \\
\hline & Diámetro trans. mitad & 24,00 \\
\hline & Diámetro trans. subtrocantero & 29,00 \\
\hline & Diámetro ap. subtrocantero & 23,00 \\
\hline & Anch. epifisis distal estimada & 77,00 \\
\hline & Diámetro vertical cabeza estimada & 47,00 \\
\hline & Diámetro horizontal de la cabeza & 45,00 \\
\hline & Índices & \\
\hline & Robustez & 19,57 \\
\hline & Pilástrico & 95,83 \\
\hline & Mérico & 79,31 \\
\hline
\end{tabular}

\begin{tabular}{|l|l|c|}
\hline \multicolumn{3}{|c|}{ Tibia: Tumba IV } \\
\hline Hemilado dcho. & \multicolumn{1}{|c|}{ Medida } & $\mathrm{mm}$ \\
\hline & Long. máx. & 376,00 \\
& Perímetro mín. & 79,00 \\
& Perímetro mitad & 85,00 \\
& Perímetro a aguj. nutric. & 100,00 \\
& Diámetro trans. aguj. nutric. & 31,00 \\
& Diámetro ap. aguj. nutric. & 20,00 \\
& Diámetro trans. mitad & 17,00 \\
& Diámetro ap. mitad & 27,00 \\
& Anch. epífisis distal & 47,00 \\
& Anchura epífisis prox. & 74,00 \\
& Long. art. condilo medial & 43,00 \\
& Anch. art. condilo medial & 30,00 \\
& Long. art. condilo lateral & 43,00 \\
& Anch. art. condilo lateral & 28,00 \\
\hline & \multicolumn{1}{|c|}{ Indices } & \\
\hline & Cnémico & 64,51 \\
& Diafisario & 62,96 \\
\hline
\end{tabular}

\begin{tabular}{|l|l|c|}
\hline \multicolumn{3}{|c|}{ Rotula: Tumba IV } \\
\hline Hemilado dcho. & \multicolumn{1}{|c|}{ Medida } & $\mathrm{mm}$ \\
\hline \multirow{3}{*}{} & Alt. máx. & 38,00 \\
& Anch. máx & 42,00 \\
& Espesor máx. & 17,00 \\
\hline & \multicolumn{1}{|c|}{ Índices } & \\
\hline & Rotuliano & 90,47 \\
\hline
\end{tabular}

\begin{tabular}{|l|l|r|}
\hline \multicolumn{3}{|c|}{ Peroné: Tumba IV } \\
\hline Hemilado izdo. & \multicolumn{1}{|c|}{ Medida } & mm \\
\hline \multirow{7}{*}{} & Long. máx. & 369,00 \\
& Perímetro mín. & 45,00 \\
& Perímetro mitad & 52,00 \\
& Diámetro máx. mitad & 11,00 \\
& Diámeto min. mitad & 7,00 \\
& Anch. epif. distal. & 23,00 \\
\hline & & \\
\hline & Robustez & 14,09 \\
& Diáfisis & 63,63 \\
\hline
\end{tabular}




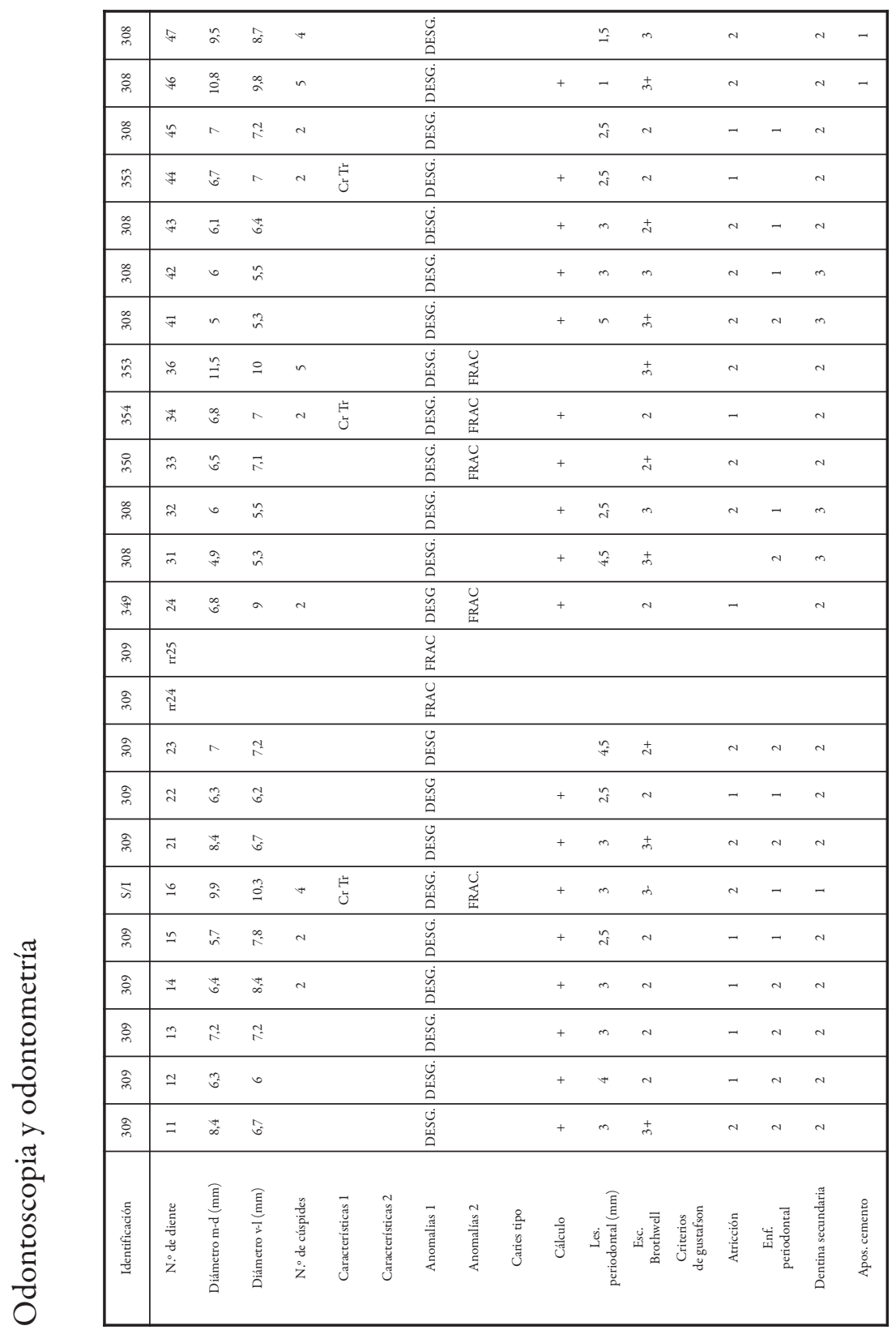




\section{Antroposcopia}

Se trata de unos restos óseos limpios, algunos restos fragmentados e incompletos; la osificación es completa. Los restos están consolidados artificialmente.

\section{Estudio radiológico}

Se realizan radiografías con placas periapicales para la valoración de las piezas dentales. También se utilizan placas mamográficas para la valoración maxilar y mandibular, así como para la valoración de las diáfisis y epífisis de huesos largos especialmente del fémur.

En estas placas se evidencian refuerzos corticales muy marcados a nivel mandibular, especialmente en la aleta goniaca y el mentón. Se aprecia también en las radiografías de los huesos largos una densidad y un grosor marcado de la capa cortical, así como unas trabéculas de hueso esponjoso muy densas y espesas.

\section{Diagnóstico del sexo}

El diagnóstico se realiza con los datos tanto del esqueleto craneal como poscraneal.

La mandíbula más cuadrangular, más gruesa y con ramas ascendentes más robustas y macizas. Eversión gonial muy marcada (prominencia de las aletas goníacas).

Robustez muy marcada en los huesos largos.

En la sínfisis de pubis se han valorado los criterios de la Tríada de Phienice; se aprecia ausencia de arco ventral, ausencia de cavidad subpúbica y la rama isquiopubiana es ancha y aplanada.

Estos datos morfológicos en su conjunto son expresivos de unos restos óseos del género masculino.

\section{Diagnóstico de la edad}

La determinación de la edad se realiza por distintos métodos, pero en la actualidad el método reconocido y estandarizado es el estudio morfológico de la metamorfosis que sufre con la evolución de la edad la unión de 
la cuarta costilla con la unión condral; valorando este método encontramos una carilla articular profunda en forma de «U» y el reborde presenta irregularidades, una carilla compatible con fase 3 según Iscan-Loth comparando con los moldes estandarizados, equivalente a una edad estimada de 24-28 años. Otro método reconocido es la valoración morfológica de la metamorfosis que sufre la cara articular sínfisis del pubis (método de Suchey-Brooks); en este caso se aprecia una conformación con extrema ondulación transversal de crestas óseas (billowing) casi paralelas entre sí. No hay margen periférico (las crestas terminan directamente sobre sup. int. articulación. Correspondiente a hombre de $18.5 \pm 2.1$ años de desviación estándar.

\section{Diagnóstico de la talla}

Atendiendo a la longitud máxima de los huesos largos de las extremidades superior e inferior y las tablas habituales podemos aproximar la talla del sujeto.

Longitud del húmero: $330 \mathrm{~mm}$; longitud del radio: 256; longitud del cúbito: 272, longitud del fémur: $472 \mathrm{~mm}$; longitud de la tibia: $376 \mathrm{~mm}$ y longitud del peroné: $369 \mathrm{~mm}$.

Tomando las tablas habituales Manouvrier, Krogman, Telka, Trotter y Gleser, etc., se estima un rango de talla de entre 166 y $173 \mathrm{~cm}$.

\section{Hallazgos de interés paleopatológico}

Marcadores de estrés óseo: estos hallazgos son valorados según los criterios de Hawkey y Merbs (1995), mediante la codificación R3, a nivel de la cara anterior corredera bicipital de la extremidad superior del húmero y de S3 en la fosa del condilo externo del fémur.

Se aprecia un grado de desgaste dental mayor, que afecta a todas las piezas, siendo mayor en los primeros molares (grado 3 + en la escala de Brothwell). Hay lesión periodontal establecida con pérdidas de insección de hasta $5 \mathrm{~mm}$ en algún caso. También se aprecia la presencia de sarro, la formación de dentina secundaria y la hipercementosis en la pieza 46. 


\section{TUMBA-V}

\section{Inventario}

ESQUELETO CRANEAL

\begin{tabular}{|c|c|c|c|}
\hline \multicolumn{4}{|c|}{ Tumba V } \\
\hline Hueso & dcho. & impar & izdo. \\
\hline Frontal & & 2 & \\
Parietal & 2 & & 2 \\
Occipital & & 2 & \\
Temporal & 2 & & 2 \\
Zigomático & 3 & & 3 \\
Palatino & 3 & & 3 \\
Maxil. sup. & 3 & & 2 \\
Nasal & & 3 & \\
Etmoides & & 3 & \\
Lacrimal & & 3 & \\
Vómer & & 3 & \\
Esfenoides & & 3 & \\
M. cuerpo & 2 & & 2 \\
M. rama & 2 & & 2 \\
\hline
\end{tabular}

INVENTARIO DENTAL

\begin{tabular}{|c|c|c|c|}
\hline \multicolumn{4}{|c|}{ Tumba V FÓRMULA F. D. I. } \\
\hline \multicolumn{4}{|c|}{ maxilar } \\
\hline pieza & dcho. & pieza & izdo. \\
\hline 51 & germ. & 61 & germ. \\
52 & 3 & 62 & germ. \\
53 & 3 & 63 & 3 \\
54 & germ. & 64 & germ. \\
55 & 3 & 65 & 3 \\
\hline \multicolumn{4}{|c|}{ mandíbula } \\
\hline pieza & dcho. & pieza & izdo. \\
\hline 81 & germ. & 71 & germ. \\
82 & germ. & 72 & \\
83 & germ. & 73 & germ. \\
84 & germ. & 74 & germ. \\
85 & 3 & 75 & 3 \\
\hline
\end{tabular}

INVENTARIO POSCRANEAL

\begin{tabular}{|c|c|c|c|}
\hline \multicolumn{4}{|c|}{ Tumba V } \\
\hline Hueso & dcho. & Impar & izdo. \\
\hline Hioides & & 3 & \\
Clavícula & 1 & & 1 \\
Omoplato & 2 & & 3 \\
Húmero & 2 & & 2 \\
Radio & 2 & & 2 \\
Cúbito & 2 & & 2 \\
Mano & 2 & & 2 \\
M. esternal & & 1 & \\
Mesoesternón & & 3 & \\
Costillas & 2 & & 2 \\
Atlas & & 2 & \\
Axis & & 2 & \\
C. 3 a 7 & & 2 & \\
D. 1 a 12 & & 2 & \\
L. 1 a 5 & & 2 & \\
Sacro & & 3 & \\
Ilión & 2 & & 2 \\
Pubis & 2 & & 2 \\
Isquión & 2 & & 2 \\
Fémur & 2 & & 2 \\
Rótula & 3 & & 3 \\
Tibia & 2 & & 2 \\
Peroné & 2 & & 2 \\
Calcáneo & 2 & & 2 \\
Astrágalo & 2 & & 2 \\
Pie & 2 & & 2 \\
\hline & & &
\end{tabular}




\section{Antropometría}

La biometría se ajusta al estado de los restos y se prioriza el lado izquierdo sobre el derecho.

\begin{tabular}{|c|c|c|}
\hline \multicolumn{3}{|c|}{ Tumba V } \\
\hline Hueso & Medida & $\mathrm{mm}$ \\
\hline Clavícula & Longitud & 35 \\
Húmero & Long. diáfisis & 50 \\
Cúbito & Long. diáfisis & 51 \\
Radio & Long. diáfisis & 45 \\
Fémur & Long. diáfisis & 59 \\
Peroné & Long. diáfisis & 51 \\
Tibia & Long. diáfisis & 52 \\
\hline
\end{tabular}

\begin{tabular}{|c|c|c|}
\hline \multicolumn{3}{|c|}{ Tumba V } \\
\hline Hueso & Medida & $\mathrm{mm}$ \\
\hline Húmero & Diám. ap./diám trans. & $1 / 1$ \\
Cúbito & Diám. ap./diám trans. & $0,25 / 0,5$ \\
Radio & Diám. ap./diám trans. & $0,25 / 0,5$ \\
Fémur & Diám. ap./diám trans. & $2 / 3$ \\
Peroné & Diám. ap./diám trans. & $0,5 / 1$ \\
Tibia & Diám. ap./diám trans. & $0,5 / 0,5$ \\
\hline
\end{tabular}

\section{Odontometría}

\begin{tabular}{|c|c|c|c|c|c|c|c|c|c|c|c|c|}
\hline Identificación & 1828 & 1828 & 1828 & 1828 & 1828 & 1828 & 1828 & 1828 & 1828 & 1828 & 1828 & 1828 \\
\hline $\begin{array}{c}\text { N. }{ }^{\circ} \text { de diente } \\
\text { Diámetro m-d (mm) }\end{array}$ & $54 ?$ & 51 & 61 & $62 ?$ & $64 ?$ & 74 & $73 ?$ & 71 & 81 & $82 ?$ & $83 ?$ & 84 \\
$\begin{array}{c}\text { Diámetro v-l (mm) } \\
\text { N. de cúspides } \\
\text { Caract. 1 }\end{array}$ & germ. & germ. & germ. & germ. & germ. & germ. & germ. & germ. & germ. & germ. & germ. & germ. \\
\hline
\end{tabular}

\section{Antroposcopia}

Se trata de unos restos esqueléticos, limpios, de reducido tamaño en los que faltan de fusionar las epífisis a las diáfisis en todos los huesos largos, tampoco están fusionadas las vértebras. Se aprecia en la valoración odontoscópica la presencia de gérmenes dentales.

\section{Estudio radiológico}

Se realiza el estudio de las radiografías de los restos mandibulares y dentales con la finalidad de evidenciar los gérmenes dentales y su estado, así como el estado de las raíces y de los alvéolos. Estos datos nos orientan en el diagnóstico de la edad. 


\section{Diagnóstico del sexo}

El diagnóstico de los patrones de dimorfismo sexual en sujetos infantiles es complejo, fundamentalmente nos basamos en el estudio de la morfología mandibular, de la morfología del hueso ilíaco y de las características odontológicas.

En la mandíbula evidenciamos:

- Pronunciamiento del mentón: el mentón es más prominente.

- Forma del arco dental anterior: el arco dental anterior es más ancho; los alvéolos caninos sobresalen con relación a los molares adyacentes, adquiriendo una forma en $\mathrm{U}$.

- Eversión de la región goníaca; el ángulo es evertido, ligeramente sobresaliente.

En el ileón comprobamos:

- El ángulo de la escotadura ciática es más angosta y se acerca a los 90.

- La profundidad de la escotadura ciática mayor es profunda.

- El criterio del arco: continúa el borde lateral de la superficie auricular.

- La curvatura de la cresta ilíaca es más pronunciada, delineando una $S$ marcada.

Estos patrones estudiados son claramente orientadores de género masculino.

\section{Diagnóstico de la edad}

Valorando el estado de osificación incompleta y la falta de fusión epifisaria y vertebral, así como estimando las longitudes de los restos diafisarios según las tablas, podemos estar ante un feto de entre 27 y 32 semanas de gestación según los percentiles (p. 58).

El esquema de Ubelaker que muestra las secuencias de formación y erupción dental es una técnica ajustada. Si valoramos el estado de los dientes, según esta tabla podríamos ajustar la edad entorno a los 7 meses de vida intrauterina, lo que equivale a unas 28 semanas. 
Diagnóstico de la talla

Según la fórmula de Olivier y Pineaud, estimando las longitudes de los huesos de extremidad superior e inferior:

Talla: 7,92 x long. del húmero $-0,32+/-1,8=39,92+/-1,8 \mathrm{~cm}$.

Talla: 7,39 x long. de la tibia $+3,55+/-1,92=41,98+/-1,92 \mathrm{~cm}$.

\section{TUMBA-VI}

Inventario

ESQUELETO CRANEAL

\begin{tabular}{|c|c|c|c|}
\hline \multicolumn{4}{|c|}{ Tumba VI } \\
\hline Hueso & dcho. & impar & izdo. \\
\hline Frontal & & 2 & \\
Parietal & 2 & & 2 \\
Occipital & & 2 & \\
Temporal & 2 & & 2 \\
Zigomático & 3 & & 3 \\
Palatino & 3 & & 2 \\
Maxil. sup. & 3 & & 2 \\
Nasal & & 3 & \\
Etmoides & & 3 & \\
Lacrimal & & 3 & \\
Vómer & & 3 & \\
Esfenoides & & 3 & \\
M. cuerpo & 2 & & 2 \\
M. rama & 2 & & 2 \\
\hline
\end{tabular}

INVENTARIO DENTAL

\begin{tabular}{|c|c|c|c|}
\hline \multicolumn{4}{|c|}{ Tumba VI FÓRMULA F. D. I. } \\
\hline \multicolumn{4}{|c|}{ maxilar } \\
\hline 51 & 3 & 61 & germ. \\
52 & germ. & 62 & germ. \\
53 & 3 & 63 & germ. \\
54 & germ. & 64 & germ. \\
55 & germ. & 65 & germ. \\
\hline \multicolumn{4}{|c|}{ mandíbula } \\
\hline pieza & dcho. & pieza & izdo. \\
\hline 81 & germ & 71 & germ. \\
82 & germ & 72 & germ. \\
83 & germ & 73 & germ. \\
84 & germ & 74 & germ. \\
85 & 3 & 75 & 3 \\
\hline
\end{tabular}

INVENTARIO POSCRANEAL

\begin{tabular}{|c|c|c|c|}
\hline \multicolumn{3}{|c|}{ Tumba V } \\
\hline Hueso & dcho. & impar & izdo. \\
\hline Hioides & 1 & 3 & 1 \\
Clavícula & 2 & & 2 \\
Omoplato & 2 & & 2 \\
Húmero & 2 & & 2 \\
Radio & 2 & & 2 \\
Cúbito & 2 & 1 & 2 \\
Mano & 3 & & \\
M. esternal & 2 & & \\
Mesoesternón & & & \\
Costillas & & & \\
Atlas & & & \\
\hline
\end{tabular}




\begin{tabular}{|c|c|c|c|}
\hline \multicolumn{3}{|c|}{ Tumba V } \\
\hline Hueso & dcho. & impar & \\
\hline Axis & & 2 & \\
C. 3 a 7 & 2 & \\
D. 1 a 12 & 2 & \\
L. 1 a 5 & 2 & 2 & \\
Sacro & 2 & 3 & 2 \\
Ilión & 2 & & 2 \\
Pubis & 2 & & 2 \\
Isquión & 3 & & 2 \\
Fémur & 2 & & 3 \\
Rótula & 2 & & 2 \\
Tibia & 2 & & 2 \\
Peroné & 3 & & 3 \\
Calcáneo & 2 & & \\
Astrágalo & & & \\
Pie & & & \\
\hline
\end{tabular}

\section{Antropometria}

La biometría se ajusta al estado de los restos y se prioriza el lado izquierdo sobre el derecho.

\begin{tabular}{|c|c|c|}
\hline \multicolumn{3}{|c|}{ Tumba VI } \\
\hline Hueso & Medida & $\mathrm{mm}$ \\
\hline Clavícula & Longitud & 43 \\
Húmero & Long. diáfisis & 63 \\
Cúbito & Long. diáfisis & 57 \\
Radio & Long. diáfisis & 49 \\
Fémur & Long. diáfisis & 74 \\
Peroné & Long. diáfisis & 60 \\
Tibia & Long. diáfisis & 62 \\
\hline
\end{tabular}

\begin{tabular}{|c|c|c|}
\hline \multicolumn{3}{|c|}{ Tumba VI } \\
\hline Hueso & Medida & $\mathrm{mm}$ \\
\hline Húmero & Diám. ap./Diám trans. & $2 / 2$ \\
Cúbito & Diám. ap./Diám trans. & $1 / 0,5$ \\
Radio & Diám. ap./Diám trans. & $0,5 / 1$ \\
Fémur & Diám. ap./Diám trans. & $3 / 4$ \\
Peroné & Diám. ap./Diám trans. & $1 / 0,25$ \\
Tibia & Diám. ap./Diám trans. & $3,5 / 3$ \\
\hline
\end{tabular}

\section{Odontometria}

\begin{tabular}{|c|c|c|c|c|c|c|c|c|c|c|c|c|c|c|c|c|}
\hline Identificación & 1978 & 1978 & 1978 & 1978 & 1978 & 1978 & 1978 & 1978 & 1978 & 1978 & 1978 & 1978 & 1978 & 1978 & 1978 & 1978 \\
\hline N. ${ }^{\circ}$ de diente & 55 & 54 & 52 & 61 & $62 ?$ & $63 ?$ & 64 & 65 & 81 & 82 & $83 ?$ & 84 & 71 & 72 & $73 ?$ & 74 \\
\hline Diámetro $\mathrm{m}-\mathrm{d}(\mathrm{mm})$ & & & & & & & & & & & & & & & & \\
\hline Diámetro v-l (mm) & & & & & & & & & & & & & & & & \\
\hline N. ${ }^{\circ}$ de cúspides & & & & & & & & & & & & & & & & \\
\hline Caract. 1 & germ. & germ. & germ. & germ. & germ. & germ. & germ. & germ. & germ. & germ. & germ. & germ. & germ. & germ. & germ. & germ. \\
\hline
\end{tabular}




\section{Antroposcopia}

Se trata de unos restos esqueléticos, limpios, de reducido tamaño en los que faltan de fusionar las epífisis a las diáfisis en todos los huesos largos, tampoco están fusionadas las vértebras. Se aprecia en la valoración odontoscópica la presencia de gérmenes dentales.

\section{Estudio radiológico}

Se realiza el estudio de las radiografías de los restos mandibulares y dentales con la finalidad de evidenciar los gérmenes dentales y su estado, así como el estado de las raíces y de los alvéolos. Estos datos nos orientan en el diagnóstico de la edad.

\section{Diagnóstico del sexo}

El diagnóstico de los patrones de dimorfismo sexual en sujetos infantiles es complejo, fundamentalmente nos basamos en el estudio de la morfología del hueso ilíaco basándonos fundamentalmente en la escotadura ciática mayor de $90^{\circ}$ y poco profunda, una cresta ilíaca en forma de $\ll S »$ atenuada y, por último, el criterio de arco, ya que la línea cruza la superficie auricular. Todo ello nos orienta a la determinación de género femenino con las dificultades que entraña esta valoración unido al fragmentado estado de la mandíbula.

\section{Diagnóstico de la edad}

Valorando el estado de osificación incompleta y la falta de fusión epifisaria y vertebral, así como estimando las longitudes de los restos diafisarios según las tablas, podemos estar ante un feto de entre 38 y 42 semanas de gestación según los percentiles (p. 59).

El esquema de Ubelaker que muestra las secuencias de formación y erupción dental es una técnica ajustada. Si valoramos el estado de los dientes según esta tabla, podríamos ajustar la edad entorno al nacimiento \pm 2 meses lo que equivale a feto a término o recién nacido con muerte perinatal.

\section{Diagnóstico de la talla}

Según la fórmula de Olivier y Pineaud, estimando las longitudes de los huesos de extremidad superior e inferior: 
Talla: 7,92 x long. del húmero $+0,32 \pm 1,8=50,22 \pm 1,8 \mathrm{~cm}$.

Talla: 7,39 x long del tibia $+3,55 \pm 1,92=49,37 \pm 1,92 \mathrm{~cm}$.

\section{TUMBA-VII}

\section{Inventario}

INVENTARIO POSCRANEAL

\begin{tabular}{|c|c|c|c|}
\hline \multicolumn{4}{|c|}{ Tumba VII } \\
\hline Hueso & dcho. & impar & $i z d o$. \\
\hline Hioides & & 3 & \\
\hline Clavícula & 3 & & 2 \\
\hline Omoplato & 3 & & 2 \\
\hline Húmero & 2 & & 2 \\
\hline Radio & 2 & & 2 \\
\hline Cúbito & 2 & & 2 \\
\hline Mano & 2 & & 2 \\
\hline M. esternal & & 3 & \\
\hline Mesoesternón & & 3 & \\
\hline Costillas & 2 & & 2 \\
\hline Atlas & & 3 & \\
\hline Axis & & 3 & \\
\hline C. 3 a 7 & & 2 & \\
\hline D. 1 a 12 & & 2 & \\
\hline L. 1 a 5 & & 2 & \\
\hline Sacro & & 2 & \\
\hline Ilión & 2 & & 2 \\
\hline Pubis & 3 & & 3 \\
\hline Isquión & 2 & & 2 \\
\hline Fémur & 2 & & 2 \\
\hline Rótula & 3 & & 2 \\
\hline Tibia & 3 & & 3 \\
\hline Peroné & 2 & & 3 \\
\hline Calcáneo & 2 & & 2 \\
\hline Astrágalo & 3 & & 3 \\
\hline Pie & 2 & & 2 \\
\hline
\end{tabular}

INVENTARIO DENTAL

\begin{tabular}{|c|c|c|c|}
\hline \multicolumn{4}{|c|}{ Tumba VII FÓRMULA F. D. I. } \\
\hline \multicolumn{4}{|c|}{ maxilar } \\
\hline 11 & 3 & 21 & 1 \\
12 & 3 & 22 & 3 \\
13 & 3 & 23 & 1 \\
14 & 3 & 24 & 3 \\
15 & 1 & 25 & 1 \\
16 & 1 & 26 & 3 \\
17 & 1 & 27 & 3 \\
18 & 1 & 28 & 1 \\
\hline \multicolumn{4}{|c|}{ mandíbula } \\
\hline pieza & dcho. & pieza & izdo. \\
\hline 41 & 3 & 31 & 3 \\
42 & 3 & 32 & 3 \\
43 & 3 & 33 & 3 \\
44 & 1 & 34 & 1 \\
45 & 3 & 35 & 3 \\
46 & 1 & 36 & 1 \\
47 & 1 & 37 & 1 \\
48 & 1 & 38 & 1 \\
\hline
\end{tabular}

ESQUELETO CRANEAL

\begin{tabular}{|c|c|c|c|}
\hline \multicolumn{5}{|c|}{ Tumba VII } \\
\hline Hueso & dcho. & impar & izdo. \\
\hline Frontal & & 2 & \\
Parietal & 2 & & 2 \\
Occipital & 2 & & 2 \\
Temporal & 2 & & 2 \\
Zigomático & 2 & & 3 \\
Palatino & 3 & & 3 \\
Maxil. sup. & 2 & & 3 \\
Nasal & & 3 & \\
Etmoides & & 3 & \\
Lacrimal & & 3 & 3 \\
Vómer & & 3 & \\
Esfenoides & & & \\
M. cuerpo & 3 & & \\
M. rama & 2 & & \\
\hline
\end{tabular}




\section{Antropometría}

\section{Extremidad superior:}

\begin{tabular}{|l|l|r|}
\hline \multicolumn{3}{|c|}{ Escápula: Tumba VIII } \\
\hline Hemilado izdo. & \multicolumn{1}{|c|}{ Medida } & $\mathrm{mm}$. \\
\hline & Long. máx. estimada & 163,00 \\
& Anchura máx. estimada & 81,00 \\
& Long. máx. espina estimada & 22,00 \\
& Longitud del borde lateral estimada & 113,00 \\
& Longitud máx. de la coracoides & \\
& Longitud máx. de la glenoidea & \\
& Anchura máx. de la glenoidea & \\
\hline & \multicolumn{1}{|c|}{ Índices } & \\
\hline & Escapular & 49,69 \\
& Glenoideo & \\
\hline
\end{tabular}

\begin{tabular}{|c|l|c|}
\hline \multicolumn{3}{|c|}{ Clavicula: Tumba VII } \\
\hline Hemilado izdo. & \multicolumn{1}{|c|}{ Medida } & $\mathrm{mm}$. \\
\hline \multirow{3}{*}{} & Long. máx. & 148,00 \\
& Perímetro Centro & 47,00 \\
& Anch. ext. & 29,00 \\
& Anch. int. estimada & 16,00 \\
\hline & Índices & \\
\hline & Robustez & 31,76 \\
\hline
\end{tabular}

\begin{tabular}{|c|c|c|}
\hline \multicolumn{3}{|c|}{ Húmero: Tumba VII } \\
\hline Hemilado izdo. & Medida & $\mathrm{mm}$ \\
\hline & Long. máx. estimada & 314,00 \\
\hline & Long. fisio. estimada & 307,00 \\
\hline & Perímetro mín. & 75,00 \\
\hline & Perímetro mitad & 79,00 \\
\hline & Diámetro máx. mitad & 22,00 \\
\hline & Diámetro mín. mitad & 17,00 \\
\hline & Anch. ep. distal & 61,00 \\
\hline & Diámetro vert. cabeza & \\
\hline & Diámetro horizontal cabeza & \\
\hline & Anch. sup. art. & 45,00 \\
\hline & Profud. troclea & 22,00 \\
\hline & Diámetro borde lat. troclea & 12,00 \\
\hline & Anch. condilo & 9,00 \\
\hline & Alt. condilo & 20,00 \\
\hline & Anch. máx. epitroclea & 22,00 \\
\hline & Diámetro AP. mín. epitroclea & 18,00 \\
\hline & Anch. fosa olecran. & 24,00 \\
\hline & Diámetro bord. ext. fosa olecra. & 15,00 \\
\hline & Diámetro bord. int. fosa olecra. & 11,00 \\
\hline & Anch. cabeza & \\
\hline & Índices & \\
\hline & Robustez & 25,16 \\
\hline & Diafisario & 77,27 \\
\hline
\end{tabular}

\begin{tabular}{|l|l|c|}
\hline \multicolumn{3}{|c|}{ Radio: Tumba VII } \\
\hline Hemilado dcho & \multicolumn{1}{|c|}{ Medida } & $\mathrm{mm}$ \\
\hline & Long. máx. estimada & 222,00 \\
& Long. fisiol. & \\
& Perímetro mín. & 50,00 \\
& Perímetro mitad & 52,00 \\
& Perímetro cabeza & 75,00 \\
& Diámetro máx. cabeza & 21,00 \\
& Diámetro mín. cabeza & 20,00 \\
& Perímetro tuber. delt. & 66,00 \\
& Diámetro trans. tuber. delt. & 11,00 \\
& Diámetro trans. mitad & 13,00 \\
& Diámetro ant.post. mitad & 9,00 \\
& Anch. epif. distal. & \\
\hline & \multicolumn{1}{|c|}{ Índices } & \\
\hline & Robustez & 23,42 \\
& Diafisario & 69,23 \\
\hline
\end{tabular}

\begin{tabular}{|r|l|r|}
\hline \multicolumn{2}{|c|}{ Cúbito: Tumba VII } \\
\hline Hemilado izq. & \multicolumn{1}{|c|}{ Medida } & \multicolumn{1}{c|}{$\mathrm{mm}$} \\
\hline & Long. máx. Estimada & 263,00 \\
& Long. fisiol. & \\
& Perímetro min. & 46,00 \\
& Perímetro mitad & 58,00 \\
& Perímetro cabeza & \\
& Diámetro máx. mitad & 14,00 \\
& Diámetro mín. mitad & 12,00 \\
& Diámetro transverso subsigmoideo & 16,00 \\
& Diametri ap. subsigmoideo & \\
& Anchu. epífisis distal. & 17,00 \\
& Altura coronoides & 228,00 \\
\hline & \multicolumn{1}{|c|}{ Índices } & \\
\hline & Robustez & 85,56 \\
& Platolemia & \\
\hline
\end{tabular}




\begin{tabular}{|c|c|c|}
\hline \multicolumn{3}{|c|}{ Rótula: Tumba VII } \\
\hline Hemilado dcho. & Medida & $\mathrm{mm}$ \\
\hline & Alt. máx. & 39,00 \\
& Anch. máx & 42,00 \\
& Espesor máx. & 17,00 \\
\hline & Índices & \\
\hline & Rotuliano & 92,86 \\
\hline
\end{tabular}

\begin{tabular}{|l|l|c|}
\hline \multicolumn{2}{|c|}{ Fémur: Tumba VII } \\
\hline Hemilado izq. & \multicolumn{1}{|c|}{ Medida } & $\mathrm{mm}$ \\
\hline \multirow{5}{*}{} & Long. máx. estimada & \\
& Long. fisiol. & \\
& Perímetro mitad & 93,00 \\
& Diámetro ap. mitad & 25,00 \\
& Diámetro trans. mitad & 27,00 \\
& Diámetro trans. subtrocantero & 27,00 \\
& Diámetro ap. subtrocantero & 28,00 \\
& Anch. epífisis distal estimada & \\
& Diámetro vertical cabeza estimada & \\
& Diámetro horizontal de la cabeza & 46,00 \\
\hline \multirow{5}{*}{ Índices } & \\
\hline & Robustez & 92,59 \\
& Pilástrico & 103,7 \\
\hline & Mérico & \\
\hline
\end{tabular}

\section{Odontometría}

\begin{tabular}{|c|c|c|c|c|c|c|c|c|c|}
\hline Identificación & 874 & 875 & 876 & 1379 & 1379 & 1400 & 1401 & 1402 & 1403 \\
\hline N. ${ }^{\circ}$ de diente & 21 & 23 & 25 & 48 & 47 & 16 & $36 ?$ & 28 & $38 ?$ \\
\hline Diámetro m-d (mm) & 8,3 & 7 & 6,3 & 10 & 10,4 & 10 & $>9,5$ & 7,8 & 9,9 \\
\hline Diámetro v-l (mm) & 6,7 & 8,5 & 8 & 9,4 & 9,2 & $11,1 ?$ & $>9,8$ & 9,5 & 9,5 \\
\hline $\mathrm{N} \cdot{ }^{\circ}$ de cúspides & & & 2 & 5 & 4 & 4 & 5 & 4 & 5 \\
\hline \multicolumn{10}{|l|}{ Características 1} \\
\hline \multicolumn{10}{|l|}{ Características 2} \\
\hline Anomalías 1 & DESG. & DESG. & DESG. & DESG. & DESG. & DESG. & DESG. & DESG. & DESG. \\
\hline Anomalías 2 & & FRAC. & FRAC. & & & FRAC. & FRAC. & FRAC. & FRAC. \\
\hline Caries tipo & & & & I ocl & I vest & & & & \\
\hline Cálculo & + & + & + & + & + & + & + & + & + \\
\hline Les. periodontal (mm) & & & & 4 & 5 & & & & \\
\hline Esc. Brothwell & $3-$ & $2+$ & $2+$ & 2 & $2+$ & 3 & $2+?$ & 2 & $2+$ \\
\hline Criterios de Gustafson & & & & & & & & & \\
\hline Atricción & 2 & 2 & 2 & 1 & 2 & 2 & 2 & 1 & 2 \\
\hline Enf. periodontal & & & & 2 & 2 & & & & \\
\hline Dentina secundaria & 2 & 1 & & 1 & 1 & 1 & 2 & & 1 \\
\hline Apos. cemento & & & & & 1 & & 1 & 1 & \\
\hline Reab. radicular & & & & & & & & & \\
\hline
\end{tabular}




\section{Odontometría}

\begin{tabular}{|c|c|c|c|c|c|c|c|}
\hline Identificación & 1404 & 1405 & 1406 & 1407 & 1408 & 1409 & 1410 \\
\hline $\mathrm{N} .^{\circ}$ de diente & 46 & 17 & 18 & 34 & 44 & 15 & 37 \\
\hline Diámetro m-d (mm) & $>10$ & 9 & 7,9 & 6,4 & 6,4 & 6,4 & 10,5 \\
\hline Diámetro v-1 (mm) & $>10$ & 11,8 & 9,6 & 7,4 & 7,2 & 8 & 9,4 \\
\hline N. ${ }^{\circ}$ de cúspides & 5 & 3 & 4 & 2 & 2 & 2 & 4 \\
\hline Características 1 & & & & Cr Tr. & Cr Tr. & & \\
\hline Características 2 & & & & & & & \\
\hline Anomalías 1 & DESG. & DESG. & DESG. & DESG. & DESG. & DESG. & DESG. \\
\hline Anomalías 2 & FRAC. & FRAC. & & & FRAC. & & FRAC. \\
\hline Caries tipo & & & & & & & \\
\hline Cálculo & + & + & + & + & + & + & + \\
\hline Les. periodontal (mm) & & & & & & & \\
\hline Esc. Brothwell & $3+$ & 2 & 2 & 2 & 2 & 3 & $3-$ \\
\hline Criterios de Gustafson & & & & & & & \\
\hline Atricción & 2 & 1 & 1 & 1 & 1 & 2 & 2 \\
\hline Enf. periodontal & & & & & & & \\
\hline Dentina secundaria & 2 & 2 & 1 & 2 & 2 & 2 & \\
\hline Apos. cemento & 1 & & 1 & & 1 & 1 & \\
\hline
\end{tabular}

\section{Antroposcopia}

Se trata de unos restos óseos limpios, algunos restos fragmentados e incompletos, la osificación es completa. Los restos están consolidados artificialmente.

\section{Estudio radiológico}

Se realizan dos tipos de pruebas radiológicas, las específicas dentales de carácter individual y periapicales con la finalidad de evidenciar el estado de las raíces y la pieza. Además, se realizan algunas placas mamográficas de restos de esta tumba, especialmente de los metatarsianos, de la epífisis superior e inferior del fémur, así como la superior del radio, ya que se intenta valorar los hallazgos antroposcópicos en forma de restos fusionados de las metáfisis.

\section{Diagnóstico del sexo}

El diagnóstico se realiza tanto con los datos del esqueleto craneal como poscraneal.

La mandíbula más cuadrangular, más gruesa especialmente en el mentón a nivel del pogonion (codificada como 5 según los estándares Buikstra y Ubelaker). 
Se evidencian los restos de la apófisis mastoides con una marcada robustez y sobresaliente (codificada como 5 según los estándares Buikstra y Ubelaker).

Robustez muy marcada en los huesos largos.

Marcada robustez de la cresta ilíaca.

Todo ello es compatible con restos óseos del género masculino.

\section{Diagnóstico de la edad}

Estudio morfológico de la metamorfosis que sufre con la evolución de la edad la unión de la cuarta costilla con la unión condral, valorando este método encontramos un aumento de la profundidad del canal artc. y adopta la forma V. Margen compatible con el inicio de la dentelladura o biselado. Hueso siempre compacto; una carilla compatible con fase 2 según Iscan-Loth comparando con moldes estandarizados, equivalente a una edad estimada de 20-23 años.

Este dato podría, además, contrastarse por los restos metafisarios hallados antroposcópica y radiológicamente en la epífisis superior del radio y en la epífisis inferior del fémur.

Diagnóstico de la talla

Valorando la longitud de los huesos largos medidos, podemos estimar un rango de la estatura; para ello recordamos las medidas:

- Longitud estimada del radio: $222 \mathrm{~mm}$.

- Longitud del cúbito: $263 \mathrm{~mm}$.

— Longitud del peroné estimada: mayor de $230 \mathrm{~mm}$.

Valorando algunas de las tablas habituales Manouvrier, Krogman, Telka, Trotter y Gleser, etc., podemos estimar una talla compatible de 160 a $165 \mathrm{~cm}$.

\section{Hallazgos paleopatológicos}

Marcadores de estrés óseo estos hallazgos son valorados según los criterios de criterios de Hawkey y Merbs (1995) mediante la codificación R3, a 
nivel de la cara anterior corredera bicipital de la extremidad superior del húmero a la que se une una marcada craterización visible en la epífisis superior del húmero.

En el estudio de los dientes de esta tumba se encontraron pequeñas caries en la pieza 47 y 48. Importante grado de desgaste dental (grados $2+$ a 3 en la escala de Brothwell). Lesión periodontal importante en las piezas 47 y 48 con 5 y $6 \mathrm{~mm}$ de pérdida de inserción. También se ha apreciado la presencia de sarro y una escasa formación, pero apreciable, de dentina secundaria. Se ha observado la fusión de las raíces de la pieza 18 .

\section{TUMBA-VIII}

\section{Inventario}

\section{ESQUELETO CRANEAL}

\begin{tabular}{|c|c|c|c|}
\hline \multicolumn{4}{|c|}{ Tumba VIII Cajas 1236/1328/1329 } \\
\hline Hueso & dcho. & impar & izdo. \\
\hline Frontal & & 1 & \\
Parietal & 1 & & 1 \\
Occipital & 2 & & 2 \\
Temporal & 1 & & 1 \\
Zigomático & 1 & & 1 \\
Palatino & 2 & & 2 \\
Maxil. sup. & 2 & & 2 \\
Nasal & 2 & & 2 \\
Etmoides & & 2 & \\
Lacrimal & 3 & & 3 \\
Vómer & & 3 & \\
Esfenoides & & 2 & \\
M. cuerpo & 1 & & 1 \\
M. rama & 1 & & 1 \\
\hline
\end{tabular}

\section{INVENTARIO DENTAL}

\begin{tabular}{|c|c|c|c|}
\hline \multicolumn{4}{|c|}{ Tumba FÓRMULA F. D. I. } \\
\hline \multicolumn{4}{|c|}{ maxilar } \\
\hline pieza & dcho. & pieza & izdo. \\
\hline 11 & 1 & 21 & 1 \\
12 & 1 & 22 & 1 \\
13 & 1 & 23 & 1 \\
14 & 1 & 24 & 1 \\
15 & 1 & 25 & 1 \\
16 & 1 & 26 & 1 \\
17 & 1 & 27 & 1 \\
18 & 1 & 28 & 1 \\
\hline \multicolumn{4}{|c|}{ mandíbula } \\
\hline pieza & dcho. & pieza & Izdo. \\
\hline 41 & 1 & 31 & 1 \\
42 & 1 & 32 & 1 \\
43 & 1 & 33 & 1 \\
44 & 1 & 34 & 1 \\
45 & 1 & 35 & 1 \\
46 & 1 & 36 & 1 \\
47 & 1 & 37 & 1 \\
48 & 1 & 38 & 1 \\
\hline
\end{tabular}

INVENTARIO POSCRANEAL

\begin{tabular}{|c|c|c|c|}
\hline \multicolumn{3}{|c|}{ Tumba VIII Cajas 1236/1328/1329 } \\
\hline Hueso & Dcho. & impar & Izqu. \\
\hline Hioides & & 3 & \\
Clavícula & 1 & & 1 \\
Omoplato & 2 & & 1 \\
Humero & 1 & & 1 \\
Radio & 2 & & 2 \\
Cubito & 1 & & 2 \\
Mano & 2 & & 2 \\
M.esternal & & 3 & \\
Mesoesternón & & 1 & \\
Costillas & 2 & & 2 \\
Atlas & & 3 & \\
Axis & & 3 & \\
C. 3 a 7 & & 2 & \\
D 1 a 12 & & 2 & \\
L. 1 a 5 & & 2 & \\
Sacro & & 1 & \\
Ilion & 1 & & 1 \\
Pubis & 2 & & 1 \\
Isquion & 2 & & 1 \\
Fémur & 2 & & 1 \\
Rotula & 1 & & 3 \\
Tibia & 1 & & 1 \\
Peroné & 1 & & 1 \\
Calcáneo & 1 & & 1 \\
Astrágalo & 1 & & 1 \\
Pie & 2 & & 2 \\
\hline & &
\end{tabular}




\section{Antropometría}

\section{Craneometría:}

\begin{tabular}{|l|l|r|}
\hline Neurocráneo & \multicolumn{1}{|c|}{ Medida } & \multicolumn{1}{c|}{$\mathrm{mm}$} \\
\hline \multirow{6}{*}{} & Long. máx & 180,00 \\
& Anchura máx. & 140,00 \\
& Anchura frontal máx. & 110,00 \\
& Anchura frontal mín. & 95,00 \\
& Anchura biastérica & 135,00 \\
& Altura basio-bregmática & 115,00 \\
& Altura auricular & 110,00 \\
& Circunferencia horizontal máx. & 530,00 \\
& Long. aguj. occipi. estimado & 30,00 \\
& Anch. aguj. occipi. estimado & 23,00 \\
\hline
\end{tabular}

\begin{tabular}{|l|l|r|}
\hline Mandíbula & \multicolumn{1}{|c|}{ Medida } & $\mathrm{mm}$ \\
\hline & Long. total & 115,00 \\
& Anch. bicondilea & 137,00 \\
& Anch. bigoníaca & 100,00 \\
& Altura de la sínfisis & 29,00 \\
& Altura de la rama & 59,00 \\
& Anchura de la rama & 34,00 \\
\hline
\end{tabular}

\begin{tabular}{|l|l|r|}
\hline Esplacnocráneo & \multicolumn{1}{|c|}{ Medida } & \multicolumn{1}{c|}{$\mathrm{mm}$} \\
\hline & Anchura bicogomática & 115,00 \\
& Altura superior de la cara & 71,00 \\
& Altura total de la cara & \\
& Anchura orbitaria derecha & 30,00 \\
& Altura orbitaria derecha & 30,00 \\
& Anchura orbitaria izquierda & 31,00 \\
& Altura orbitaria izquierda & 31,00 \\
& Anchura nasal & 19,00 \\
& Altura nasal estimada & 53,00 \\
& Anchura del paladar & 35,00 \\
& Long. del paladar & 43,00 \\
& Anchura arco alveolar & 57,00 \\
& Long. arco alveolar estimada & 48,00 \\
& Diámetro basión alveolar & 105,00 \\
& Diámetro nasión basión & 90,00 \\
\hline
\end{tabular}

\begin{tabular}{|l|c|l|}
\hline \multicolumn{1}{|c|}{ Índices } & Rdo. & \\
\hline Craneal & 77,78 & Mesaticéfalo subdolicocefalo \\
Verticolongitudinal & 63,89 & Camecraneo cráneo bajo \\
Verticotransversal & 82,14 & Tapeinocráneo cráneo bajo \\
Frontal & 86,36 & \\
Facial total & & \\
Facial superior & 61,74 & Hiperlepteno \\
Orbitario derecho & 100,00 & Hipsiconco \\
Orbitario izquierdo & 100,00 & Hipsiconco \\
Nasal & 35,85 & Leptorrino \\
Palatino & 81,40 & Mesoestafilino \\
De la arcada alveolar & 118,75 & Braquiuránico \\
Gnático & 116,67 & Prognato \\
Aguja occipital & 76,67 & Microsema \\
Mandibular & 83,94 & Braquignato \\
De rama & 57,63 & Ancha \\
\hline
\end{tabular}

\section{Extremidad superior:}

\begin{tabular}{|l|l|r|}
\hline \multicolumn{3}{|c|}{ Clavícula: Tumba VIII } \\
\hline Hemilado dcho. & \multicolumn{1}{|c|}{ Medida } & $\mathrm{mm}$ \\
\hline & Long. máx. & 137,00 \\
& Perímetro centro & 43,00 \\
& Anch. ext. & 22,00 \\
& Anch. int. & 22,00 \\
\hline & \multicolumn{1}{|c|}{ Indices } & \\
\hline & Robustez & 31,39 \\
\hline
\end{tabular}

\begin{tabular}{|l|l|r|}
\hline \multicolumn{3}{|c|}{ Radio: Tumba VIII } \\
\hline Hemilado Dcho. & \multicolumn{1}{|c|}{ Medida } & $\mathrm{mm}$ \\
\hline & Long. máx. & \\
& Long. fisiol. & \\
& Perímetro mín. & \\
& Perímetro mitad & 69,00 \\
& Perímetro cabeza & 20,00 \\
& Diámetro máx. cabeza & 18,00 \\
& Diámetro mín. cabeza & 53,00 \\
& Perímetro tuber. delt. & \\
& Diámetro trans. tuber. delt. & \\
& Diámetro trans. mitad & 11,00 \\
& Diámetro ant. pos. mitad & 9,00 \\
& Anch. epif. distal. & \\
\hline & \multicolumn{2}{|c|}{ Índices } \\
\hline & Robustez & \\
\hline & Diafisario & \\
\hline
\end{tabular}




\begin{tabular}{|l|l|c|}
\hline \multicolumn{2}{|c|}{ Húmero: Tumba VIII } \\
\hline Hemilado izdo. & \multicolumn{2}{|c|}{ Medida } \\
\hline & Long. máx. & 308,00 \\
& Long. fisio. & 300,00 \\
& Perímetro mín. & 66,00 \\
& Perímetro mitad & 70,00 \\
& Diámetro máx. mitad & 17,00 \\
& Diámetro min. mitad. & 16,00 \\
& Anch. ep. distal & 61,00 \\
& Diámetro vertical cabeza & 40,00 \\
& Diámetro horizontal cabeza & 45,00 \\
& Anch. sup. art. & 42,00 \\
& Profud. troclea & 21,00 \\
& Diámetro borde lat. troclea & 16,00 \\
& Anch. condilo & 13,00 \\
& Alt. condilo & 17,00 \\
& Anch. máx. epitroclea & 24,00 \\
& Diámetro ap. mín. epitroclea & 12,00 \\
& Anch. fosa olecran. & 12,00 \\
& Diámetro bord. ext. fosa olecra. & 19,00 \\
& Diámetro bord. int. fosa olecra. & 18,00 \\
& Anch. cabeza. & 45,00 \\
\hline \multirow{5}{*}{} & Robustez Índices & 22,73 \\
& Diafisario & 94,12 \\
\hline
\end{tabular}

\begin{tabular}{|l|l|c|}
\hline \multicolumn{2}{|c|}{ Cubito: Tumba VIII } \\
\hline Hemilado Dcho. & \multicolumn{1}{|c|}{ Medida } & $\mathrm{mm}$ \\
\hline \multirow{2}{*}{} & Long. máx. & 257,00 \\
& Long. fisiol. & 253,00 \\
& Perímetro mín. & 45,00 \\
& Perímetro mitad & 52,00 \\
& Diámetro ap. subsigmoideo & 18,00 \\
& Diámetro máx. mitad & 14,00 \\
& Diámetro mín. mitad & 8,00 \\
& Diámetro transverso subsigmoideo & 16,00 \\
& Anchura epifisi distal. & 12,00 \\
& Altura coronoides & 227,00 \\
\hline & & \\
\hline & Robustez Índices & 3,11 \\
& Platolemia & 57,14 \\
\hline
\end{tabular}

\section{Extremidad inferior:}

\begin{tabular}{|c|c|c|}
\hline \multicolumn{3}{|c|}{ Coxal: Tumba VIII } \\
\hline \multirow[t]{11}{*}{ Hemilado izdo. } & Medida & $\mathrm{mm}$ \\
\hline & Altura total & 208,00 \\
\hline & Anch. máx. del ileón & 160,00 \\
\hline & Diámetro menor del ileón & 68,00 \\
\hline & Long. carilla auricular & 57,00 \\
\hline & Diámetro isqueopúbico máx. & 102,00 \\
\hline & Longitud del pubis & 49,00 \\
\hline & Diámetro de la cav. cotiloidea & 52,00 \\
\hline & Ángulo subpúbico & 26,00 \\
\hline & Longitud de la sínfisis del pubis & 44,00 \\
\hline & Anchura de la sínfisis del pubis & 15,00 \\
\hline \multicolumn{3}{|c|}{ Peroné: Tumba VIII } \\
\hline \multirow[t]{10}{*}{ Hemilado izdo. } & Medida & $\mathrm{mm}$ \\
\hline & Long. máx. & 338,00 \\
\hline & Perímetro mín. & 43,00 \\
\hline & Perímetro mitad & 47,00 \\
\hline & Diámetro máx. mitad. & 11,00 \\
\hline & Diámeto mín. mitad & 8,00 \\
\hline & Anch. epif. distal. & 22,00 \\
\hline & Índices & \\
\hline & Robustez & 13,91 \\
\hline & Diáfisis & 72,73 \\
\hline
\end{tabular}

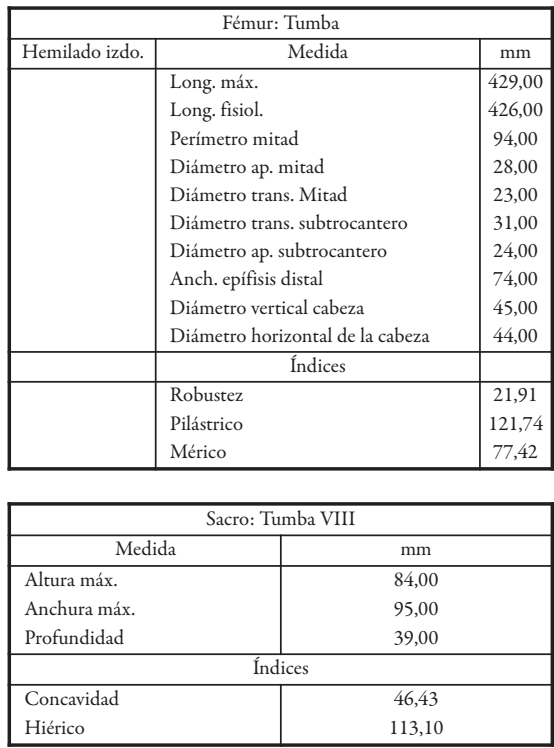




\begin{tabular}{|l|l|c|}
\hline \multicolumn{3}{|c|}{ Tibia: Tumba VIII } \\
\hline Hemilado izdo. & \multicolumn{1}{|c|}{ Medida } & $\mathrm{mm}$ \\
\hline & Long. máx. & 355,00 \\
& Perímetro mín. & 83,00 \\
& Perímetro mitad & 80,00 \\
& Perímetro a aguj. nutric. & 95,00 \\
& Diámetro trans. aguj. nutric. & 21,00 \\
& Diámetro ap. aguj. nutric. & 25,00 \\
& Diámetro trans. mitad & 17,00 \\
& Diámetro ap. mitad & 26,00 \\
& Anchura epífisis distal & 47,00 \\
& Anchura epífisis prox. & 71,00 \\
& Long. art. condilo medial & 44,00 \\
& Anch. art. condilo medial & 25,00 \\
& Long. art. condilo lateral & 39,00 \\
& Anch. art. condilo lateral & 34,00 \\
\hline & \multicolumn{1}{|c|}{ Índices } & \\
\hline & Cnémico & 84 \\
& Diafisario & 65,38 \\
\hline
\end{tabular}

\begin{tabular}{|l|l|c|}
\hline \multicolumn{3}{|c|}{ Rotula: Tumba IV } \\
\hline Hemilado dcho. & Medida & $\mathrm{mm}$ \\
\hline & Alt. máx. & 39,00 \\
& Anch. max & 37,00 \\
& Espesor máx. & 17,00 \\
\hline & Índices & \\
\hline & Rotuliano & 105,41 \\
\hline
\end{tabular}

\begin{tabular}{|c|l|c|}
\hline \multicolumn{3}{|c|}{ Astragalo Tumba VIII } \\
\hline Hemilado izdo. & \multicolumn{1}{|c|}{ medida } & $\mathrm{mm}$ \\
\hline & Long. máx. & 48,00 \\
\hline & Anchura máxima & 39,00 \\
\hline & Altura & 25,00 \\
\hline & \multicolumn{1}{|c|}{ Indices } & \\
\hline & Anchura & 81,25 \\
\hline & Altura & 52,08 \\
\hline
\end{tabular}

\begin{tabular}{|l|l|c|}
\hline \multicolumn{3}{|c|}{ Calcaneo Tumba VIII } \\
\hline Hemilado izdo. & \multicolumn{1}{|c|}{ Medida } & $\mathrm{mm}$ \\
\hline & Long. máx. & 73,00 \\
& Anchura mínima & 23,00 \\
& Altura mínima & 24,00 \\
\hline & \multicolumn{1}{|c|}{ Índices } & \\
\hline & Anchura & 31,51 \\
& Altura & 32,88 \\
\hline
\end{tabular}

\section{Odontometría}

\begin{tabular}{|l|c|c|c|c|c|c|c|c|}
\hline \multicolumn{1}{|c|}{ Identificación } & 1758 & 1758 & 1758 & 1758 & 1758 & 1758 & 1758 & 1758 \\
\hline N. ${ }^{\circ}$ de diente & 18 & 17 & 16 & 15 & 14 & 13 & 12 & 11 \\
Díámetro m-d (mm) & 8,2 & 8,8 & 9,2 & 5,8 & 6,2 & 7 & 6 & 7,4 \\
Diámetro v-l (mm) & 8,8 & 9,2 & 10 & 7,5 & 7,3 & 7,3 & 5,7 & 6,3 \\
N. ${ }^{\text {de cúspides }}$ & 3 & 4 & 4 & 2 & 2 & & & \\
Características 1 & & & & & & & & \\
Características 2 & & & & & & & \\
Anomalías 1 & DESG. & DESG. & DESG. & DESG. & DESG. & DESG. & DESG. & DESG \\
Anomalías 2 & & & FRAC. & & & & & \\
Caries tipo & & & & & & & & \\
Cálculo & + & + & + & + & + & + & + & + \\
Les. periodontal (mm) & 2,5 & 3,5 & 5 & 3 & 4 & 3,5 & 3 & 2,5 \\
Esc. Brothwell & $3-$ & 4 & 5 & $5+$ & $3-4$ & 3 & 3 & 3 \\
Criterios de Gustafson & & & & & & & & 2 \\
Atricción & 2 & 2 & $2-3$ & 2 & 2 & 2 & 2 & 2 \\
Enf. periodontal & 2 & 2 & 2 & $1-2$ & 2 & 2 & 2 & 2 \\
\hline
\end{tabular}




\section{Odontometría}

\begin{tabular}{|c|c|c|c|c|c|c|c|c|}
\hline Identificación & 1758 & 1758 & 1758 & 1758 & 1758 & 1758 & 1758 & 1758 \\
\hline N.o de diente & 21 & 22 & 23 & 24 & 25 & 26 & 27 & 28 \\
\hline Diámetro m-d (mm) & 7,3 & 5,7 & 7 & 6,1 & 5,7 & 9,1 & 8,8 & 8 \\
\hline Diámetro v-l (mm) & 6,4 & 5,9 & 7,5 & 7,1 & 7,4 & 10,1 & 9,4 & 8,8 \\
\hline N. ${ }^{\circ}$ de cúspides & & & & 2 & 2 & 4 & 4 & 3 \\
\hline Características 1 & & & & & & & & \\
\hline Características 2 & & & & & & & & \\
\hline Anomalías 1 & DESG. & DESG. & DESG. & DESG. & DESG. & DESG. & DESG. & DESG. \\
\hline Anomalías 2 & & FRAC. & & & & FENE. & & \\
\hline Caries tipo & & & & & & & & \\
\hline Cálculo & + & + & + & + & + & + & + & + \\
\hline Les. periodontal (mm) & 3 & 2 & 4 & 3 & 2 & 5,5 & 5 & 5 \\
\hline Esc. Brothwell & 3 & 3 & 3 & $3+$ & 4 & 5 & $3+$ & $3-$ \\
\hline Criterios de Gustafson & & & & & & & & \\
\hline Atricción & 2 & 2 & 2 & 2 & 2 & $2-3$ & 2 & 2 \\
\hline Enf. periodontal & 2 & 1 & 2 & $1-2$ & 1 & $2-3$ & $2-3$ & $2-3$ \\
\hline
\end{tabular}

\section{Antroposcopia}

Se trata de restos óseos limpios consolidados artificialmente y bien conservados. Su osificación es completa, se restauran con fines antropológicos el cráneo y algunos restos. Junto a los restos humanos de esta tumba se halla un astrágalo no humano, compatible por sus características anatómicas comparadas con el de un caballo.

\section{Estudio radiológico}

Se realiza un estudio radiológico de las piezas dentales situadas tanto en el maxilar como en la mandíbula mediante ortopantomografía, una telemetría y cefalometría. Se realiza, además, un estudio mediante radiografía simple en placas mamográficas de la epífisis superior de tibia, fémur, peroné y húmero. Se radiografía el astrágalo no humano encontrado.

El hallazgo más demostrativo es la enorme opacidad de las trabéculas del hueso esponjoso en las epífisis de los huesos largos, dato asociado a la robustez valorada antroposcópica y antropométricamente. 


\section{Diagnóstico del sexo}

Cuando tenemos el esqueleto craneal casi completo junto a la mandíbula, así como el coxal, podemos afirmar con exactitud el diagnóstico de dimorfismo sexual. Para ello empleamos a nivel craneal los criterios estandarizados Buikstra y Ubelaker; fundamentalmente se estudian la glabela, reborde supraciliar, apófisis mastoides, línea nucal y morfología occipital, y mentón. En estos perfiles morfoantropológicos obtenemos códigos puntuados como 4 y 5 (género masculino).

A nivel de la pelvis nos basamos fundamentalmente en la Tríada de Phenice en la sínfisis de pubis, ausencia de arco ventral, ausencia de cavidad subpúbica, y la rama isquiopubiana es ancha y aplanada, todo ello compatible con el género masculino; estos datos se asocian a la morfología de la carilla auricular, la escotadura ciática, etc., también claramente orientadoras del género masculino.

El esqueleto poscraneal y en concreto las características y dimensiones de los huesos largos son también propias del género masculino.

\section{Diagnóstico de la edad}

Estudio morfológico de la metamorfosis que sufre con la evolución de la edad la unión de la cuarta costilla con la unión condral, valorado este método encontramos que la forma del canal articular empieza a pasar de forma $\mathrm{V}$ a $\mathrm{U}$. El margen comienza a presentar irregularidades. El hueso más bien compacto, una carilla compatible con fase 3 según Iscan-Loth, comparando con moldes estandarizados, equivalente a una edad estimada de un hombre de 24-28 años.

Mediante estadios sínfisis pubiana (método Suchey-Brooks) se evidencia presencia todavía de algún signo juvenil (presencia de alguna cresta). El margen todavía tiende a completarse en el interior del perímetro de la articulación. La vertiente dorsal inferior está completa, mientras que la ventral superior está en fase de terminación. No hay osteofitos. Es la fase 3 y se estima un varón de $28.7 \pm 6.5$ años.

\section{Diagnóstico de la talla}

Atendiendo a la longitud máxima de los huesos largos de las extremidades superior e inferior y las tablas habituales, podemos aproximar la talla del sujeto: 
- Longitud del húmero: $308 \mathrm{~mm}$; longitud del cúbito: 257; longitud del fémur: $429 \mathrm{~mm}$; longitud de la tibia: $355 \mathrm{~mm}$; y longitud del peroné: $338 \mathrm{~mm}$.

Se estima con las tablas habituales Manouvrier, Krogman, Telka, Trotter y Gleser, etc., un rango de talla de entre 155 y $165 \mathrm{~cm}$.

\section{Hallazgos paleopatológicos}

1. Se aprecian multitud de marcadores de actividad osteomuscular en la epífisis proximal del fémur, especialmente en la línea intertrocanterera, se asocia a craterizaciones en el cuello femoral; son valoradas como R3 y S3. En la epífisis distal del fémur, concretamente a nivel del condilo externo, se aprecian fosas muy marcadas para inserciones musculares (R3). A nivel tibial es de destacar en la epífisis proximal y concretamente en la tuberosidad tibial anterior signos de periostitis con estriaciones y depresiones junto con hoyos profundos y extensos (más de $3 \mathrm{~mm}$ de profundidad y $5 \mathrm{~mm}$ de superficie) en superficie que nos obligan a valorar con los criterios de Hawkey y Merbs como R3 y S3, además estos hallazgos serían compatibles con enfermedad de Osgood-Schlatter. En el peroné se aprecia una osificación tendinosa de más de $5 \mathrm{~mm}$ sobre la superficie del hueso (Os 3). En la cara posterior del calcáneo se aprecian excrecencias y estriaciones interpuestas; reflejando la acción de robustos en todos los casos estudiados, la valoración con los criterios utilizados deben estimarse con $\mathrm{S} 3$.

2. En esta tumba, además, con el estudio odontológico se encontró un grado de desgaste dental severo en algunas piezas (grados 3 a 5 + en la escala de Brothwell), la presencia de sarro, lesiones periodontales importantes, con pérdidas de inserción que van desde 2,5 a 5,5 mm y fenestración en la cara vestibular de la pieza 26. 
TUMBA-IX

Inventario

ESQUELETO CRANEAL

\begin{tabular}{|l|c|c|c|}
\hline \multicolumn{4}{|c|}{ Tumba IX Caja 1291 } \\
\hline \multicolumn{1}{|c|}{ Hueso } & dcho. & impar & izdo. \\
\hline Frontal & & 2 & \\
Parietal & 2 & & 2 \\
Occipital & & 2 & \\
Temporal & 2 & & 2 \\
Zigomático & 2 & & 2 \\
Palatino & 3 & & 3 \\
Maxil. sup. & 3 & & 3 \\
Nasal & & 3 & \\
Etmoides & & 3 & \\
Lacrimal & & 3 & \\
Vómer & & 3 & \\
Esfenoides & & 3 & \\
M. cuerpo & 3 & & 3 \\
M. rama & 2 & & 2 \\
\hline
\end{tabular}

INVENTARIO DENTAL

\begin{tabular}{|c|c|c|c|}
\hline \multicolumn{4}{|c|}{ Tumba IX FÓRMULA F. D. I. } \\
\hline \multicolumn{4}{|c|}{ maxilar } \\
\hline pieza & dcho. & pieza & izdo. \\
\hline 11 & 3 & 21 & 3 \\
12 & 3 & 22 & 3 \\
13 & 3 & 23 & 3 \\
14 & 3 & 24 & 3 \\
15 & 3 & 25 & 1 \\
16 & 1 & 26 & 1 \\
17 & 3 & 27 & 1 \\
18 & 3 & 28 & 3 \\
\hline \multicolumn{5}{|c|}{ mandíbula } \\
\hline pieza & dcho. & pieza & izdo. \\
\hline 41 & 3 & 31 & 3 \\
42 & 3 & 32 & 3 \\
43 & 3 & 33 & 3 \\
44 & 1 & 34 & 1 \\
45 & 3 & 35 & 2 \\
46 & 1 & 36 & 2 \\
47 & 1 & 37 & 2 \\
48 & 3 & 38 & 1 \\
\hline
\end{tabular}

INVENTARIO POSCRANEAL

\begin{tabular}{|c|c|c|c|}
\hline \multicolumn{4}{|c|}{ Tumba IX Caja 1291} \\
\hline Hueso & dcho. & impar & $i z d o$. \\
\hline Hioides & & 3 & \\
\hline Clavícula & 2 & & 2 \\
\hline Omoplato & 2 & & 2 \\
\hline Húmero & 2 & & 2 \\
\hline Radio & 2 & & 2 \\
\hline Cúbito & 2 & & 2 \\
\hline Mano & 2 & & 2 \\
\hline M. esternal & & 1 & \\
\hline Mesoesternón & & 2 & \\
\hline Costillas & & 2 & \\
\hline Atlas & & 2 & \\
\hline Axis & & 2 & \\
\hline C. 3 a 7 & & 2 & \\
\hline D. 1 a 12 & & 2 & \\
\hline L. 1 a 5 & & 2 & \\
\hline Sacro & & 2 & \\
\hline Ilión & 2 & & 2 \\
\hline Pubis & 3 & & 2 \\
\hline Isquión & 2 & & 2 \\
\hline Fémur & 2 & & 2 \\
\hline Rótula & 3 & & 1 \\
\hline Tibia & 2 & & 2 \\
\hline Peroné & 2 & & 1 \\
\hline Calcáneo & 1 & & 1 \\
\hline Astrágalo & 3 & & 1 \\
\hline Pie & 2 & & 2 \\
\hline
\end{tabular}




\section{Antropometría}

\section{Extremidad superior:}

\begin{tabular}{|l|l|c|}
\hline \multicolumn{3}{|c|}{ Húmero: Tumba IX } \\
\hline Hemilado izdo. & \multicolumn{1}{|c|}{ Medida } & mm \\
\hline \multirow{1}{*}{} & Long. máx. est. & 292,00 \\
& Long. fisio. est. & 290,00 \\
& Perímetro mín. & 73,00 \\
& Perímetro mitad & 84,00 \\
& Diámetro máx. mitad & 23,00 \\
& Diámetro mín. mitad & 20,00 \\
& Anch. ep. distal & 57,00 \\
& Diámetro vert. cabeza & 43,00 \\
& Diámetro horizontal cabeza & 40,00 \\
& Anch. sup. art. & 44,00 \\
& Profud. troclea & 19,00 \\
& Diámetro borde lat. troclea & 22,00 \\
& Anch. condilo & 13,00 \\
& Alt. condilo & 16,00 \\
& Anch. máx. epitroclea & 21,00 \\
& Diámetro ap. mín. epitroclea & 13,00 \\
& Anch. fosa olecran. & 24,00 \\
& Diámetro bord. ext. fosa olecra. & 14,00 \\
& Diámetro bord. int. fosa olecra. & 9,00 \\
& Anch. cabeza. & 48,00 \\
\hline & & \\
\hline & Robustez & 28,77 \\
& Diafisario & 86,96 \\
\hline \multirow{5}{*}{} & \\
\hline
\end{tabular}

\begin{tabular}{|l|l|c|}
\hline \multicolumn{2}{|c|}{ Cúbito: Tumba IX } \\
\hline Hemilado izdo. & \multicolumn{1}{|c|}{ Medida } & $\mathrm{mm}$ \\
\hline \multirow{1}{*}{} & Long. máx. & 269,00 \\
& Long. fisiol. & 264,00 \\
& Perímetro mín. & 58,00 \\
& Perímetro mitad & 61,00 \\
& Diámetro ap. subsigmoideo & 22,00 \\
& Diámetro máx. mitad & 15,00 \\
& Diámetro mín. mitad & 13,00 \\
& Diámetro transverso subsigmoideo & 18,00 \\
& Anchu. epífisis distal & 16,00 \\
& Altura coronoides & 240,00 \\
\hline & & \\
\hline & Robustez & 4,83 \\
& Platolemia & 86,67 \\
\hline
\end{tabular}

\begin{tabular}{|l|l|c|}
\hline \multicolumn{3}{|c|}{ Radio: Tumba IX } \\
\hline Hemilado izdo. & \multicolumn{1}{|c|}{ Medida } & $\mathrm{mm}$ \\
\hline \multirow{5}{*}{} & Long. máx. estimada & 215,00 \\
& Long. fisiol. est. & 213,00 \\
& Perímetro min. & 57,00 \\
& Perímetro mitad & 60,00 \\
& Perímetro cabeza & 83,00 \\
& Diámetro máx. cabeza & 22,00 \\
& Diámetro mín. cabeza & 20,00 \\
& Perímetro tuber. delt. & 67,00 \\
& Diámetro trans. tuber. delt. & 14,00 \\
& Diámetro trans. mitad & 14,00 \\
& Diámetro ant. post mitad & 15,00 \\
& Anch. epif. distal. & 29,00 \\
\hline & \multicolumn{1}{|c|}{ Índices } & \\
\hline & Robustez & \\
& Diafisario &
\end{tabular}




\section{Extremidad inferior:}

\begin{tabular}{|l|l|c|}
\hline \multicolumn{2}{|c|}{ Fémur: Tumba IX } & \\
\hline Hemilado dcho. & \multicolumn{1}{|c|}{ Medida } & $\mathrm{mm}$ \\
\hline \multirow{3}{*}{ Fragmentado } & Long. máx. & \\
& Long. fisiol. & \\
& Perímetro mitad & \\
& Diámetro ap. mitad & \\
& Diámetro trans. Mitad & \\
& Diámetro trans. subtrocantero & \\
& Diámetro ap. subtrocantero & 76,00 \\
& Anch. epífisis distal & 46,00 \\
& Diámetro vertical cabeza & \\
& Diámetro horizontal de la cabeza & \\
\hline & & \\
\hline & Robustez & \\
& Pilástrices & \\
& Mérico & \\
\hline
\end{tabular}

\begin{tabular}{|l|l|c|}
\hline \multicolumn{3}{|c|}{ Tibia: Tumba IX } \\
\hline Hemilado Izdo. & \multicolumn{1}{|c|}{ Medida } & $\mathrm{mm}$ \\
\hline & Long. máx. & 364,00 \\
& Perímetro mín. & 88,00 \\
& Perímetro mitad & 97,00 \\
& Perímetro a aguj. nutric. & 105,00 \\
& Diámetro trans. aguj. nutric. & 25,00 \\
& Diámetro ap. aguj. nutric. & 35,00 \\
& Diámetro trans. mitad & 21,00 \\
& Diámetro ap. mitad & 29,00 \\
& Anchura epífisis distal & 45,00 \\
& Anchura epífisis próx. estm. & 75,00 \\
& Long. art. condilo medial & frag. \\
& Anch. art. condilo medial & frag. \\
& Long. art. condilo lateral & frag. \\
& Anch. art. condilo lateral & frag. \\
\hline & \multicolumn{2}{|c|}{ Índices } \\
\hline & Cnemico & 71,43 \\
& Diafisario & 72,41 \\
\hline
\end{tabular}

\begin{tabular}{|l|l|c|}
\hline \multicolumn{3}{|c|}{ Calcaneo Tumba IX } \\
\hline Hemilado izdo. & \multicolumn{1}{|c|}{ Medida } & $\mathrm{mm}$ \\
\hline & Long. máx. & 72,00 \\
& Anchura mínima & 29,00 \\
& Altura mínima & 18,00 \\
\hline & \multicolumn{1}{|c|}{ Índices } & \\
\hline & Anchura & 40,28 \\
& Altura & 25,00 \\
\hline
\end{tabular}

\begin{tabular}{|l|l|c|}
\hline \multicolumn{3}{|c|}{ Peroné: Tumba IX } \\
\hline Hemilado Izdo. & \multicolumn{1}{|c|}{ Medida } & $\mathrm{mm}$ \\
\hline & Long. máx. & 352,00 \\
& Perímetro mín. & 51,00 \\
& Perímetro mitad & 62,00 \\
& Diámetro máx. mitad. & 17,00 \\
& Diámeto mín. mitad & 13,00 \\
& Anch. epif. distal. & 24,00 \\
\hline & \multicolumn{1}{|c|}{ Índices } & \\
\hline & Robustez & 17,61 \\
& Diáfisis & 76,47 \\
\hline
\end{tabular}

\begin{tabular}{|l|l|c|}
\hline \multicolumn{3}{|c|}{ Rótula: Tumba IX } \\
\hline Hemilado dcho. & \multicolumn{1}{|c|}{ Medida } & $\mathrm{mm}$ \\
\hline & Alt. máx. & 38,00 \\
& Anch. max & 39,00 \\
& Espesor máx. & 16,00 \\
\hline & Índices & \\
\hline & Rotuliano & 97,44 \\
\hline
\end{tabular}

\begin{tabular}{|l|l|c|}
\hline \multicolumn{3}{|c|}{ Astrágalo: Tumba IX } \\
\hline Hemilado Izdo. & \multicolumn{1}{|c|}{ Medida } & $\mathrm{mm}$ \\
\hline & Long. máx. & 50,00 \\
& Anchura máxima & 41,00 \\
& Altura & 27,00 \\
\hline & \multicolumn{1}{|c|}{ Índices } & \\
\hline & Anchura & 82,00 \\
& Altura & 54,00 \\
\hline
\end{tabular}




\begin{tabular}{|c|c|c|c|c|c|c|c|c|c|c|c|c|c|c|c|c|c|c|}
\hline & $\underset{\overbrace{}}{\stackrel{f}{\approx}}$ & $\stackrel{\text { m }}{\xi}$ & & & & & & 胥 & & & & & & & & & & - \\
\hline & $\stackrel{\text { fే }}{2}$ & $\stackrel{0}{0}$ & & & & & & 岁 & & & & & & & & & & - \\
\hline & $\stackrel{f}{\stackrel{f}{2}}$ & $\stackrel{n}{\xi}$ & & & & & & 岁 & & & & & & & & & & - \\
\hline $\begin{array}{l}\frac{8}{\mathscr{U}} \\
\ddot{n} \\
\ddot{n}\end{array}$ & $\begin{array}{l}\tilde{n} \\
\stackrel{n}{n}\end{array}$ & $\stackrel{i}{ }$ & $\stackrel{\infty}{\sigma}$ & $a$ & & & & 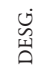 & 晏 & & & & $\stackrel{+}{m}$ & & $N$ & & & \\
\hline 总 & 命 & $\mathbb{F}$ & in & t't & $N$ & $\dot{H}$ & & 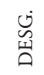 & 崖 & & & & $\stackrel{+}{m}$ & & $\sim$ & & $N$ & - \\
\hline$\frac{8}{\mathscr{U}}$ & $\hat{\tilde{\Omega}}$ & $\infty$ & $\hat{\sigma}$ & $\stackrel{\infty}{\infty}^{0}$ & in & & & 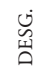 & & & + & $\hat{i}$ & $m$ & & $N$ & & $N$ & $N$ \\
\hline$\frac{8}{\mathscr{U}}$ & ڤิ) & $\stackrel{m}{m}$ & $i^{\infty}$ & 3 & $N$ & $\vec{H}$ & & 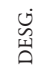 & 兗 & & + & & $\stackrel{+}{m}$ & & $N$ & & $\sim$ & I \\
\hline 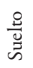 & $\begin{array}{c}\infty \\
\tilde{n}\end{array}$ & 2 & $\vec{\sigma}$ & $\hat{\sigma}$ & $N$ & & & $\begin{array}{l}\text { 岕 } \\
\text { M }\end{array}$ & 莠 & & + & N & $\stackrel{+}{m}$ & & $\sim$ & & $N$ & $\stackrel{I}{I}$ \\
\hline 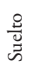 & $\mid \begin{array}{l}\tilde{n} \\
\tilde{2}\end{array}$ & fे & $\sigma^{2}$ & $a$ & t & & & 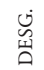 & & & + & $N$ & $\stackrel{+}{m}$ & & $N$ & & $N$ & - \\
\hline 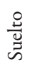 & $\begin{array}{l}\stackrel{0}{\Omega} \\
\cong\end{array}$ & $\hat{\lambda}$ & $\infty$ & $t_{\infty}^{+}$ & $m$ & & & 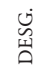 & 晏 & & + & & N & & - & & N & \\
\hline 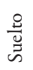 & $\overrightarrow{\tilde{n}}$ & to & 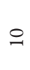 & $\sigma$ & in & & & 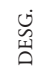 & 㝕 & & + & $m$ & $\sim$ & & - & & I & - \\
\hline 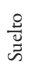 & 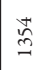 & $\stackrel{\circ}{\circ}$ & $\stackrel{6}{\sigma}$ & $\overrightarrow{0}$ & t & & & 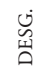 & 晏 & & & & 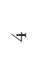 & & & & & \\
\hline 弟 & 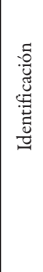 & 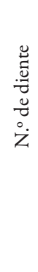 & 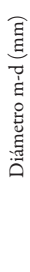 & 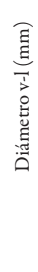 & 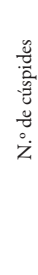 & 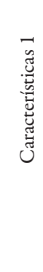 & 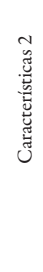 & 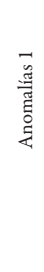 & 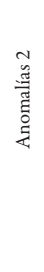 & 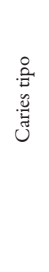 & $\frac{0}{\frac{\vec{E}}{\bar{v}}}$ & 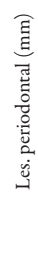 & 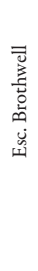 & 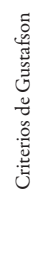 & 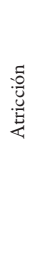 & 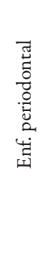 & 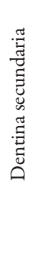 & 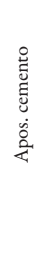 \\
\hline
\end{tabular}




\section{Antroposcopia}

Se trata de restos fragmentados, limpios y parcialmente consolidados.

\section{Estudio radiológico}

Se realiza un estudio radiográfico de piezas mediante placas periapicales; se radiografían los dientes $25,26,27,34,36,37,38,44,46$ y 47 así como la raíz del 35.

\section{Diagnóstico del sexo}

Nos basamos fundamentalmente en la Tríada de Phenice en los restos de sínfisis de pubis presentes en esta tumba con ausencia de arco ventral, ausencia de cavidad subpúbica y la rama isquiopubiana que es ancha y aplanada, estos datos son claramente orientadores del género masculino.

El esqueleto poscraneal y en concreto las características y dimensiones de los huesos largos, el diámetro de la cabeza femoral (mayor de $46 \mathrm{~mm}$ ), la robustez y la morfología son también propias del género masculino.

\section{Diagnóstico de la edad}

Estudio morfológico de la metamorfosis que sufre con la evolución de la edad la unión de la cuarta costilla con la unión condral, valorando este método encontramos un canal articular casi siempre en forma de U. Bordes un poco más irregulares pero todavía biselado (festoneado). El hueso es más ligero y menos compacto. Compatible con fase $4(\mathrm{~m} 4 \mathrm{~b})$ según Iscan-Loth comparando con moldes estandarizados, equivalente a una edad estimada de hombre de 26-32 años.

Mediante estadios sínfisis pubiana (método Suchey-Brooks) teniendo en cuenta que está fragmentada y solo tenemos los $2 / 3$ superiores, se evidencia un margen periférico completo (aún con una pequeña discontinuidad ventral superior). Superficie de la sínfisis de aspecto granular muy fino, con restos de billowing. Excrecencias óseas solo en porción inferior y dorsal. Es compatible con la fase 4 y se estima en varón de $35.2 \pm 9.4$ años.

Diagnóstico de la talla

Valorando la longitud de los huesos largos medidos, podemos estimar un rango de la estatura, para ello recordamos las medidas: 
- Longitud del húmero: $292 \mathrm{~mm}$.

- Longitud del radio: $215 \mathrm{~mm}$.

- Longitud del cúbito: $269 \mathrm{~mm}$.

- Longitud del peroné: $352 \mathrm{~mm}$.

- Longitud de la tibia: $364 \mathrm{~mm}$.

Se estima con las tablas habituales Manouvrier, Krogman, Telka, Trotter y Gleser, etc., un rango de talla de entre 160 y $170 \mathrm{~cm}$.

\section{Hallazgos paleopatológicos}

1. Se aprecian hallazgos propios de marcadores de actividad osteomuscular o marcadores de estrés óseo en distintas localizaciones tanto en la extremidad superior como inferior:

a) En la extremidad superior: en el húmero, en la corredera bicipital se aprecia un marcado canal profundo. Aparecen hoyos o craterizaciones. A nivel diafisario se evidencian relieves y asperezas en la cortical con crestas y depresiones, algunas de estas asperezas son propias de periostitis con rugosidad en los bordes diafisarios. Estos hallazgos son valorados por los criterios expuestos con anterioridad con R3. (criterios de Hawkey y Merbs)

b) En la extremidad inferior: concretamente en los restos diafisarios de la tibia signos de periostitis con estriaciones y depresiones junto con hoyos profundos y extensos (más de $3 \mathrm{~mm}$ de profundidad y $5 \mathrm{~mm}$ de superficie) en superficie que nos obligan a valorar con los criterios de Hawkey y Merbs como R3 y S3. Destacamos también en la epífisis distal del fémur, concretamente a nivel del condilo externo, que se aprecia fosas muy marcadas para inserciones musculares (R3). Por último, se aprecian en la cara anterior de la rótula estriaciones y marcas generadas por la impronta del tendón rotuliano, no con la profundidad y la extensión de otras localizaciones S2. En esta misma rótula se aprecia una excrecencia ósea en forma de pequeña exostosis degenerativa en el borde interno, que podemos calificar como Os3. 
2. Además del sarro presente en todas las piezas dentales estudiadas, se aprecia un alto grado de desgaste dental (grados $3+$ a 4 en la escala de Brothwell), lesiones periodontales de $3 \mathrm{~mm}$ formación de dentina secundaria y aposición incrementada de cemento radicular. Hay fusión de las raíces de la pieza 38.

\section{TUMBA-X}

\section{Inventario}

INVENTARIO DENTAL

\begin{tabular}{|c|c|c|c|}
\hline \multicolumn{4}{|c|}{ Tumba FÓRMULA F. D. I. } \\
\hline \multicolumn{4}{|c|}{ maxilar } \\
\hline pieza & dcho. & pieza & izdo. \\
\hline 11 & 3 & 21 & 3 \\
12 & 3 & 22 & 3 \\
13 & incluido & 23 & 3 \\
14 & 2 & 24 & 2 \\
15 & 3 & 25 & 3 \\
16 & 3 & 26 & 3 \\
17 & 3 & 27 & 3 \\
18 & 3 & 28 & 3 \\
\hline \multicolumn{4}{|c|}{ mandíbula } \\
\hline pieza & dcho. & pieza & izdo. \\
\hline 41 & 3 & 31 & 3 \\
42 & 3 & 32 & 3 \\
43 & 3 & 33 & 3 \\
44 & 3 & 34 & 3 \\
45 & 3 & 35 & 3 \\
46 & 3 & 36 & 3 \\
47 & 3 & 37 & 3 \\
48 & 3 & 38 & 3 \\
\hline
\end{tabular}

INVENTARIO POSCRANEAL

\begin{tabular}{|l|c|c|c|}
\hline \multicolumn{5}{|c|}{ Tumba X Caja 1307} \\
\hline \multicolumn{1}{|c|}{ Hueso } & dcho. & impar & izdo. \\
\hline Hioides & & 3 & \\
Clavícula & 3 & & 3 \\
Omoplato & 2 & & 2 \\
Húmero & 2 & & 1 \\
Radio & 2 & & 3 \\
Cúbito & 1 & & 1 \\
Mano & 3 & & 3 \\
M. esternal & & 2 & \\
Mesoesternón & & 2 & \\
Costillas & 2 & & 2 \\
Atlas & & 3 & \\
Axis & & 3 & \\
C. 3 a 7 & & 2 & \\
D. 1 a 12 & & 2 & \\
L. 1 a 5 & & 2 & \\
Sacro & & 2 & \\
Ilión & 2 & & 2 \\
Pubis & 2 & & 2 \\
Isquión & 2 & & 2 \\
Fémur & 1 & & 1 \\
Rótula & 3 & & 3 \\
Tibia & 2 & & 1 \\
Peroné & 3 & & 3 \\
Calcáneo & 3 & & 3 \\
Astrágalo & 3 & & 3 \\
Pie & 3 & & 3 \\
\hline
\end{tabular}


ESQUELETO CRANEAL

\begin{tabular}{|l|c|c|c|}
\hline \multicolumn{5}{|c|}{ Tumba X Caja 1307 } \\
\hline \multicolumn{1}{|c|}{ Hueso } & dcho. & impar & izdo. \\
\hline Frontal & & 2 & \\
Parietal & 2 & & 2 \\
Occipital & & 2 & \\
Temporal & 2 & & 2 \\
Zigomático & 2 & & \\
Palatino & 1 & & 1 \\
Maxil. sup. & 2 & & 2 \\
Nasal & 3 & & 3 \\
Etmoides & & 3 & \\
Lacrimal & 3 & 3 & 3 \\
Vómer & & 3 & \\
Esfenoides & & 3 & \\
M. cuerpo & & 3 & \\
M. rama & & & \\
\hline
\end{tabular}

\section{Antropometría}

\section{Extremidad superior:}

\begin{tabular}{|l|l|r|}
\hline \multicolumn{3}{|c|}{ Húmero: Tumba X } \\
\hline Hemilado izqdo. & \multicolumn{1}{|c|}{ Medida } & $\mathrm{mm}$ \\
\hline & Long. máx. estimada & 272,00 \\
& Long. fisio. estimada & 269,00 \\
& Perímetro mín. & 61,00 \\
& Perímetro mitad & 65,00 \\
& Diámetro máx. mitad & 16,00 \\
& Diámetro mín. mitad & 14,00 \\
& Anch. ep. distal. & 51,00 \\
& Diámetro vert. cabeza & 36,00 \\
& Diámetro horizontal cabeza & 35,00 \\
& Anch. sup. art. & 39,00 \\
& Profud. troclea & 19,00 \\
& Diámetro borde lat. troclea & 14,00 \\
& Anch. condilo & 11,00 \\
& Alt. condilo & 14,00 \\
& Anch. max. epitroclea & 15,00 \\
& Diámetro ap. min. epitroclea & 12,00 \\
& Anch. fosa olecran. & 21,00 \\
& Diámetro bord. ext. fosa olecra. & 16,00 \\
& Diámetro bord. int. fosa olecra. & 11,00 \\
& Anch. cabeza. & 39,00 \\
\hline & \multicolumn{2}{|c|}{ Índices } \\
\hline & Robustez & 23,90 \\
& Diafisario & 87,50 \\
\hline
\end{tabular}

\begin{tabular}{|l|l|c|}
\hline \multicolumn{3}{|c|}{ Radio: Tumba X } \\
\hline Hemilado Izdo. & \multicolumn{1}{|c|}{ Medida } & $\mathrm{mm}$ \\
\hline & Long. máx. estimada & 199,00 \\
& Long. fisiol. & 197,00 \\
& Perímetro mín. & 41,00 \\
& Perímetro mitad & 46,00 \\
& Perímetro cabeza & 62,00 \\
& Diámetro máx. cabeza & 16,00 \\
& Diámetro mín. cabeza & 15,00 \\
& Perímetro tuber. delt. & 49,00 \\
& Diámetro trans. tuber. delt. & 12,00 \\
& Diámetro trans. mitad & 12,00 \\
& Diámetro ant. post. mitad & 8,00 \\
& Anch. epif. distal. & 26,00 \\
\hline & \multicolumn{1}{|c|}{ Índices } & \\
\hline & Robustez & 23,12 \\
& Diafisario & 66,67 \\
\hline
\end{tabular}




\begin{tabular}{|l|l|c|}
\hline \multicolumn{2}{|c|}{ Cúbito: Tumba X } \\
\hline Hemilado Izdo. & \multicolumn{1}{|c|}{ Medida } & $\mathrm{mm}$ \\
\hline & Long. máx. estimada & 223,00 \\
& Long. fisiol. & 221,00 \\
& Perímetro mín. & 39,00 \\
& Perímetro mitad & 48,00 \\
& Diámetro máx. mitad & 10,00 \\
& Diámetro mín. mitad & 7,00 \\
& Diámetro transverso subsigmoideo & 14,00 \\
& Diámetro ap. subsigmoideo & 15,00 \\
& Anchu. epífisis distal. & 16,00 \\
& Altura coronoides & 22,00 \\
\hline & \multicolumn{2}{|c|}{ Indices } \\
\hline & Robustez & 3,14 \\
& Platolemia & 70,00 \\
\hline
\end{tabular}

\section{Extremidad inferior:}

\begin{tabular}{|l|l|c|}
\hline \multicolumn{2}{|c|}{ Fémur: Tumba X } \\
\hline Hemilado Dcho. & \multicolumn{1}{|c|}{ Medida } & $\mathrm{mm}$ \\
\hline & Long. máx. & 393,00 \\
& Long. fisiol. & 391,00 \\
& Perímetro mitad & 84,00 \\
& Diámetro ap. mitad & 22,00 \\
& Diámetro trans. Mitad & 24,00 \\
& Diámetro trans. subtrocantero & 27,00 \\
& Diámetro ap. subtrocantero & 24,00 \\
& Anch. epífisis distal & 67,00 \\
& Diámetro vertical de la cabeza & 39,00 \\
& Diámetro horizontal de la cabeza & 37,00 \\
\hline & \multicolumn{1}{|c|}{ Índices } \\
\hline & Robustez & 21,37 \\
& Pilástrico & 91,67 \\
& Mérico & 88,89 \\
\hline
\end{tabular}

\begin{tabular}{|l|l|c|}
\hline \multicolumn{3}{|c|}{ Tibia: Tumba X } \\
\hline Hemilado Izdo. & \multicolumn{1}{|c|}{ Medida } & $\mathrm{mm}$ \\
\hline \multirow{7}{*}{} & Long. máx. & 309,00 \\
& Perímetro mín. & 74,00 \\
& Perímetro mitad & 82,00 \\
& Perímetro a aguj. nutric. & 83,00 \\
& Diámetro trans. aguj. nutric. & 18,00 \\
& Diámetro ap. aguj. nutric. & 27,00 \\
& Diámetro trans. mitad & 16,00 \\
& Diámetro ap. mitad & 24,00 \\
& Anchura epífisis distal & 45,00 \\
& Anchura epífisis prox. & 62,00 \\
& Long. art. condilo medial & 41,00 \\
& Anch. art. condilo medial & 25,00 \\
& Long. art. condilo lateral & 31,00 \\
& Anch. art. condilo lateral & 29,00 \\
\hline & \multicolumn{2}{|c|}{ Índices } \\
\hline & Cnémico & 66,67 \\
& Diafisario & 66,67 \\
\hline
\end{tabular}




\section{Odontoscopia y Odontometría}

\begin{tabular}{|c|c|c|c|}
\hline Identificación & 445 & 445 & 445 \\
\hline N.o de diente & rr 24 & rr 14 & 13 \\
\hline Diámetro m-d (mm) & 3,1 & 3,7 & \\
\hline Diámetro v-l (mm) & 6,5 & 7 & \\
\hline $\mathrm{N} .{ }^{\circ}$ de cúspides & & & \\
\hline Características 1 & & & INCLU. \\
\hline Características 2 & & & \\
\hline Anomalias 1 & DESG. & DESG. & \\
\hline Anomalias 2 & ABSC. & ABSC. & \\
\hline Caries tipo & & & \\
\hline Cálculo & & & \\
\hline Les. periodontal $(\mathrm{mm})$ & & & \\
\hline Esc. Brothwell & 6 & 6 & \\
\hline Criterios de Gustafson & & & \\
\hline Atricción & 3 & 3 & \\
\hline
\end{tabular}

\section{Antroposcopia}

Los huesos están fragmentados, limpios y consolidados artificialmente.

\section{Estudio radiológico}

Se realizan placas periapicales sobre todo del canino incluido (13) y de las raíces 14 y 24 . Además, nos permiten evidenciar los alvéolos de los incisivos.

\section{Diagnóstico del sexo}

La presencia del foramen magno y su morfología, con un Índice Condileo de Boudin inferior a 50; el ángulo subpúbico marcado; las dimensiones del fémur especialmente de la cabeza femoral de $39 \mathrm{~mm}$, nos orientan a pensar en el género femenino como más probable.

\section{Diagnóstico de la edad}

Estudio morfológico de la metamorfosis que sufre con la evolución de la edad la unión de la cuarta costilla con la unión condral; valorando este método encontramos canal con forma de $U$ alargada. La pared adelgazada, aumentando las irregularidades de los márgenes. El hueso más frágil y poroso. Fase 5 según Iscan-Loth comparando con moldes estandarizados, equivalente a una edad estimada de mujer de 33-46 años. 
Estos datos serían compatibles con los hallazgos degenerativos con focos artrósicos rotulianos e ilíacos.

Diagnóstico de la talla

Valorando la longitud de los huesos largos medidos, podemos estimar un rango de la estatura, para ello recordamos las medidas:

— Longitud del húmero: $272 \mathrm{~mm}$.

- Longitud del radio: $199 \mathrm{~mm}$

- Longitud del cúbito: $223 \mathrm{~mm}$

- Longitud del fémur: $393 \mathrm{~mm}$.

- Longitud de la tibia: $309 \mathrm{~mm}$.

Se estima con las tablas habituales Manouvrier, Krogman, Telka, Trotter y Gleser, etc., se estima un rango de talla de entre 145 y $155 \mathrm{~cm}$.

\section{Hallazgos paleopatológicos}

1. En el estudio odontológico de estos restos se aprecia un intenso grado de desgaste dental (grado 6 en la escala de Brothwel) en las piezas 14 y 24 que han provocado la formación de abscesos con zonas de osteolisis del hueso alveolar.

Se observa una malposición del canino superior derecho (13) que se encuentra incluído en la dirección mesial.

2. Marcadores de estrés:

a) Epífisis proximal del fémur: las crestas marcadas con depresiones intercaladas en la epífisis proximal del fémur especialmente en la línea intertrocanterera, se asocian a craterizaciones en el cuello femoral y son valoradas como R3 y S3.

b) Diáfisis femoral: el desarrollo de la cresta glútea ha sido asociado con el tránsito por una accidentada orografía.

c) Epífisis distal del fémur: en la epífisis distal del fémur, concretamente a nivel del condilo externo, se aprecian fosas muy marcadas para inserciones musculares (R3).

d) Epífisis proximal de la tibia: concretamente en la tuberosidad tibial anterior signos de periostitis con estriaciones y depre- 
siones junto con hoyos profundos y extensos (más de $3 \mathrm{~mm}$ de profundidad y $5 \mathrm{~mm}$ de superficie) en superficie que nos obligan a valorar con los criterios de Hawkey y Merbs como R3 y S3, además estos hallazgos serían compatibles con enfermedad de Osgood-Schlatter.

e) Epífisis distal de la tibia: carilla lateral de acuclillamiento se aprecia como una carilla deprimida, casi un surco, que nos orienta a pensar en el acuclillamiento o marcha prolongada por terrenos irregulares.

f) Coxal: en la cresta ilíaca de algunos se aprecian en los bordes insercionales, excrecencias y rugosidades junto con pequeñas exostosis (S3,Os2).

3. Osteocondritis en la cara articular del condilo femoral externo, la afectación de una zona periférica del hueso en la carilla articular, con el cartílago que la recubre recibe la denominación de osteocondritis. Se produce por traumatismo o necrosis avascular.

4. En la cabeza y cuello femoral se aprecia una variación discontinua en forma de carilla sobresaliente que se conoce como faceta de Charles. 


\section{TUMBA-XI}

\section{Inventario}

ESQUELETO CRANEAL

\begin{tabular}{|c|c|c|c|}
\hline \multicolumn{5}{|c|}{ Tumba XI Caja 1178 } \\
\hline Hueso & dcho. & impar & izdo. \\
\hline Frontal & & 2 & \\
Parietal & 2 & & 2 \\
Occipital & & 2 & \\
Temporal & 2 & & 2 \\
Zigomático & 2 & & 2 \\
Palatino & & 3 & \\
Maxil. sup. & & 3 & \\
Nasal & & 3 & \\
Etmoides & & 3 & \\
Lacrimal & & 3 & \\
Vómer & & 3 & \\
Esfenoides & & 3 & \\
M. cuerpo & & 3 & \\
M. rama & & 3 & \\
\hline
\end{tabular}

INVENTARIO DENTAL

\begin{tabular}{|c|c|c|c|}
\hline \multicolumn{4}{|c|}{ Tumba XI FÓRMULA F. D. I. } \\
\hline \multicolumn{4}{|c|}{ maxilar } \\
\hline pieza & dcho. & pieza & izdo. \\
\hline 11 & 3 & 21 & 3 \\
12 & 3 & 22 & 3 \\
13 & 3 & 23 & 3 \\
14 & 3 & 24 & 3 \\
15 & 3 & 25 & 3 \\
16 & 3 & 26 & 3 \\
17 & 3 & 27 & 3 \\
18 & 3 & 28 & 3 \\
\hline \multicolumn{4}{|c|}{ mandíbula } \\
\hline pieza & dcho. & pieza & izdo. \\
41 & 3 & 31 & 3 \\
42 & 3 & 32 & 3 \\
43 & 3 & 33 & 3 \\
44 & 3 & 34 & 3 \\
45 & 3 & 35 & 3 \\
46 & 3 & 36 & 3 \\
47 & 3 & 37 & 3 \\
48 & 3 & 38 & 3 \\
\hline \multicolumn{4}{|c}{} \\
\end{tabular}

INVENTARIO POSCRANEAL

\begin{tabular}{|c|c|c|c|}
\hline \multicolumn{4}{|c|}{ Tumba XI Caja 1178} \\
\hline Hueso & dcho. & impar & $i z d o$. \\
\hline Hioides & & 3 & \\
\hline Clavícula & 3 & & 3 \\
\hline Omoplato & 2 & & 3 \\
\hline Húmero & 2 & & 2 \\
\hline Radio & 2 & & 2 \\
\hline Cúbito & 2 & & 2 \\
\hline Mano & 2 & & 2 \\
\hline M. esternal & & 3 & \\
\hline Mesoesternón & & 3 & \\
\hline Costillas & 2 & & 2 \\
\hline Atlas & & 3 & \\
\hline Axis & & 3 & \\
\hline C. 3 a 7 & & & \\
\hline D. 1 a 12 & & 2 & \\
\hline L. 1 a 5 & & 2 & \\
\hline Sacro & & 2 & \\
\hline Ilión & 2 & & 2 \\
\hline Pubis & 2 & & 3 \\
\hline Isquión & 2 & & 3 \\
\hline Fémur & 2 & & 2 \\
\hline Rótula & 3 & & 3 \\
\hline Tibia & 3 & & 3 \\
\hline Peroné & 3 & & 3 \\
\hline Calcáneo & 3 & & 3 \\
\hline Astrágalo & 3 & & 3 \\
\hline Pie & 3 & & 3 \\
\hline
\end{tabular}




\section{Antropometría}

\begin{tabular}{|c|c|c|}
\hline \multicolumn{3}{|c|}{ Húmero: Tumba XI Caja 1178} \\
\hline Hemilado Izdo. & Medida & $\mathrm{mm}$ \\
\hline & Long. máx. & 331,00 \\
\hline & Long. fisio. & 322,00 \\
\hline & Perímetro mín. & 78,00 \\
\hline & Perímetro mitad & 90,00 \\
\hline & Diámetro máx. mitad & 23,00 \\
\hline & Diámetro mín. mitad & 18,00 \\
\hline & Anch. ep. distal. & 58,00 \\
\hline & Diámetro vertical cabeza & 42,00 \\
\hline & Diámetro horizontal cabeza & 41,00 \\
\hline & Anch. sup. art. & 39,00 \\
\hline & Profud. troclea & 25,00 \\
\hline & Diámetro borde lat. troclea & 22,00 \\
\hline & Anch. condilo estimado & 13,00 \\
\hline & Alt. condilo estimado & 20,00 \\
\hline & Anch. máx. epitroclea & 24,00 \\
\hline & Diámetro ap. mín. epitroclea & 15,00 \\
\hline & Anch. fosa olecran. & 15,00 \\
\hline & Diámetro bord. ext. fosa olecra. & 28,00 \\
\hline & Diámetro bord. int. fosa olecra. & 16,00 \\
\hline & Anch. cabeza. estimada & 47,00 \\
\hline & Índices & \\
\hline & Robustez & 23,56 \\
\hline & Diafisario & 78,26 \\
\hline
\end{tabular}

\begin{tabular}{|l|l|c|}
\hline \multicolumn{2}{|c|}{ Radio: Tumba XI Caja 1178 } \\
\hline Hemilado Izdo. & \multicolumn{1}{|c|}{ Medida } & $\mathrm{mm}$ \\
\hline & Long. máx. & 248,00 \\
& Long. fisiol. & 243,00 \\
& Perímetro mín. & 50,00 \\
& Perímetro mitad & 54,00 \\
& Perímetro cabeza & 74,00 \\
& Diámetro máx. cabeza estimado & 21,00 \\
& Diámetro mín. cabeza & 18,00 \\
& Perímetro tuber. delt. & 57,00 \\
& Diámetro trans. tuber delt. & 13,00 \\
& Diámetro trans. mitad & 9,00 \\
& Diámetro ant. post mitad & 12,00 \\
& Anch. epíf. distal. & 31,00 \\
\hline \multicolumn{1}{|c|}{ Índices } & \\
\hline & Robustez & 75,00 \\
\hline & Diafisario & \\
\hline
\end{tabular}

\section{Antroposcopia}

Se trata de una serie de restos muy consolidados pero muy fragmentados.

\section{Diagnóstico radiológico}

Se realizan placas mamográficas de cuerpo vertebral y de restos diafisarios de los huesos largos. Se aprecia en el cuerpo vertebral la impronta en la esponjosa, y en los huesos largos la presencia muy marcada de trabéculas radioopacas muy densas en las diáfisis.

\section{Diagnóstico del sexo}

Se realiza con los perfiles antropométricos por criterios estandarizados Buikstra y Ubelaker; fundamentalmente se estudia la glabela, reborde supraciliar, salientes, robustas y romas que podemos codificar con 5, claramente compatibles con el género masculino. 
Se asocia esta valoración diagnóstica a la valoración antroposcópica de la Tríada de Phenice en los restos de sínfisis de pubis presentes en esta tumba con ausencia de arco ventral, ausencia de cavidad subpúbica y la rama isquiopubiana que es ancha y aplanada, estos datos claramente orientadores del género masculino.

Se unen a esta valoración la morfología del sacro largo y excavado, así como una carilla auricular larga, compatible también con el género masculino.

Diagnóstico de la edad

Se utilizan los restos costales hallados en esta tumba y la sínfisis de pubis conservada casi en su integridad.

En cuanto a los datos obtenidos de la valoración morfológica de la metamorfosis que sufre con la evolución de la edad la unión de la cuarta costilla con la unión condral, por el método Iscan-Loth podemos valorar que la forma del canal articular empieza a pasar de forma $\mathrm{V}$ a U. El margen comienza a presentar irregularidades, el hueso más bien compacto. Datos que hacen compatible, si comparamos con los moldes estandarizados con la fase 3 (M3a), con hombre de 24-28 años.

Por tener completa una de las sínfisis del pubis, utilizando el método de la morfología del pubis (metodo Suchey-Brooks) se aprecia la presencia todavía de algún signo juvenil (presencia de alguna cresta). El margen todavía tiende a completarse en el interior del perímetro de la articulación. La vertiente dorsal inferior está completa, mientras que la ventral superior está en fase de terminación. No hay osteofitos. Datos que sitúan los hallazgos en la fase 3: hombre de $28.7 \pm 6.5$ años.

\section{Diagnóstico de la talla}

Valorando la longitud de los huesos largos medidos, podemos estimar un rango de la estatura, para ello recordamos las medidas:

- Longitud del húmero: $331 \mathrm{~mm}$.

- Longitud del radio: $248 \mathrm{~mm}$.

Se estima con las tablas habituales Manouvrier, Krogman, Telka, Trotter y Gleser, etc., un rango de talla de entre $168-172 \mathrm{~cm}$. 


\section{Hallazgos paleopatológicos}

1. Marcadores de estrés o de actividad osteomuscular se ven fundamentalmente en los condilos femorales a través de una marcada craterización, así como a nivel del condilo externo se aprecia fosas muy marcadas para inserciones musculares (R3), según criterios de Hawkey y Merbs.

2. Se aprecia en un cuerpo vertebral a nivel de la cara superior la impronta que dejó una hernia discal, aunque no podremos valorarlo con los criterios empleados, nos orienta a pensar en acciones biomecánicas intensas. 


\section{TUMBA-XII}

\section{Inventario}

ESQUELETO CRANEAL

\begin{tabular}{|c|c|c|c|}
\hline \multicolumn{5}{|c|}{ Tumba XII Caja 1292 } \\
\hline Hueso & dcho. & impar & izdo. \\
\hline Frontal & & 2 & \\
Parietal & 2 & & 2 \\
Occipital & & 2 & \\
Temporal & 2 & & 3 \\
Zigomático & 3 & & 3 \\
Palatino & 3 & & 3 \\
Maxil. sup. & 3 & & 3 \\
Nasal & 3 & & 3 \\
Etmoides & 3 & & 3 \\
Lacrimal & 3 & & 3 \\
Vómer & & 3 & \\
Esfenoides & & 3 & 3 \\
M. cuerpo & 3 & & 2 \\
M. rama & 2 & & \\
\hline
\end{tabular}

INVENTARIO DENTAL

\begin{tabular}{|c|c|c|c|}
\hline \multicolumn{4}{|c|}{ Tumba XII FÓRMULA F. D. I. } \\
\hline \multicolumn{4}{|c|}{ maxilar } \\
\hline pieza & dcho. & pieza & izdo. \\
\hline 11 & 3 & 21 & 3 \\
12 & 3 & 22 & 3 \\
13 & 3 & 23 & 3 \\
14 & 3 & 24 & 3 \\
15 & 3 & 25 & 3 \\
16 & 3 & 26 & 3 \\
17 & 3 & 27 & 3 \\
18 & 3 & 28 & 3 \\
\hline \multicolumn{5}{|c|}{ mandíbula } \\
\hline pieza & dcho. & pieza & izdo. \\
\hline 41 & 3 & 31 & 3 \\
42 & 3 & 32 & 3 \\
43 & 3 & 33 & 3 \\
44 & 3 & 34 & 3 \\
45 & 3 & 35 & 3 \\
46 & 3 & 36 & 1 \\
47 & 3 & 37 & 1 \\
48 & 3 & 38 & 1 \\
\hline
\end{tabular}

INVENTARIO POSCRANEAL

\begin{tabular}{|c|c|c|c|}
\hline \multicolumn{5}{|c|}{ Tumba XII } \\
\hline Hueso & dcho. & impar & izdo. \\
\hline Hioides & & 3 & \\
Clavícula & 1 & & 1 \\
Omoplato & 2 & & 2 \\
Húmero & 1 & & 3 \\
Radio & 3 & & 3 \\
Cúbito & 3 & & 3 \\
Mano & 2 & & 2 \\
M. esternal & & 3 & \\
Mesoesternón & & 2 & \\
Costillas & 2 & & 2 \\
Atlas & & 3 & \\
Axis & & 3 & \\
C. 3 a 7 & & 2 & \\
D. 1 a 12 & & 2 & \\
L. 1 a 5 & & 2 & \\
Sacro & & 3 & 3 \\
Ilión & 3 & & 3 \\
Pubis & 3 & & 3 \\
Isquión & 3 & & 3 \\
Fémur & 3 & & 3 \\
Rótula & 3 & & 3 \\
Tibia & 3 & & 3 \\
Peroné & 3 & & 3 \\
Calcáneo & 3 & & \\
Astrágalo & 3 & & 3 \\
Pie & 3 & & \\
\hline
\end{tabular}




\section{Antropometría}

\begin{tabular}{|c|l|c|}
\hline \multicolumn{3}{|c|}{ Clavícula: Tumba XII Caja 1292} \\
\hline Hemilado izdo. & \multicolumn{1}{|c|}{ Medida } & $\mathrm{mm}$ \\
\hline & Long. máx. & 139,00 \\
& Perímetro centro & 36,00 \\
& Anch. ext. & 15,00 \\
& Anch. ínt. & 15,00 \\
\hline & \multicolumn{1}{|c|}{ Indices } & \\
\hline & Robustez & 25,90 \\
\hline
\end{tabular}

\begin{tabular}{|l|l|c|}
\hline \multicolumn{2}{|c|}{ Húmero: Tumba XII Caja 1292 } \\
\hline Hemilado izdo. & \multicolumn{1}{|c|}{ Medida } & $\mathrm{mm}$ \\
\hline & Long. máx. & 297,00 \\
& Long. fisio. & 295,00 \\
& Perímetro mín. & 56,00 \\
& Perímetro mitad & 59,00 \\
& Diámetro máx. mitad & 16,00 \\
& Diámetro mín. mitad & 11,00 \\
& Anch. ep. distal. & 48,00 \\
& Diámetro vertical cabeza & 34,00 \\
& Diámetro horizontal cabeza & 32,00 \\
& Anch. sup. art. & 31,00 \\
& Profud. troclea & 17,00 \\
& Diámetro borde lat. troclea & 13,00 \\
& Anch. condilo & 13,00 \\
& Alt. condilo & 15,00 \\
& Anch. máx. epitroclea & 14,00 \\
& Diámetro ap. mín. epitroclea & 11,00 \\
& Anch. fosa olecran & 19,00 \\
& Diámetro bord. ext. fosa olecra & 12,00 \\
& Diámetro bord. int. fosa olecra & 7,00 \\
& Anch. cabeza & 38,00 \\
\hline & & \\
\hline & Robustez & 19,87 \\
& Diafisario & 68,75 \\
\hline
\end{tabular}

\section{Odontoscopia y Odontometría}

\begin{tabular}{|l|c|c|c|}
\hline \multicolumn{1}{|c|}{ Identificación } & 397 & 397 & 397 \\
\hline N. ${ }^{\circ}$ diente & 37 & 36 & 35 \\
Diámetro m-d (mm) & 9,9 & 9 & 5,2 \\
Diámetro v-l (mm) & 8,7 & 7,8 & 7,4 \\
N. ${ }^{\circ}$ de cúspides & 4 & 5 & 2 \\
Características 1 & & & \\
Características 2 & DESG. & DESG. & DESG. \\
Anomalías 1 & & & \\
Anomalías 2 & & & \\
Caries tipo & + & $>10$ & + \\
Cálculo & 6 & $5++$ & 5 \\
Les. periodontal (mm) & 4 & 3 & 3 \\
Esc. Brothwell & 2 & 3 & 2 \\
Criterios de Gustafson & 2 & 3 & 3 \\
Atricción & 3 & & \\
Enf. periodontal & 2 & & \\
Dentina secundaria & & & \\
Apos. cemento & & & \\
\hline
\end{tabular}




\section{Antroposcopia}

Son restos muy fragmentados, consolidados y con signos degenerativos en muchos de los restos.

\section{Estudio radiológico}

Se realiza un estudio con placas periapicales de las piezas en la región mandibular para evidenciar el estado de las raíces y de los alvéolos.

\section{Diagnóstico del sexo}

Se realiza con los perfiles antropométricos por criterios estandarizados Buikstra y Ubelaker, fundamentalmente se estudian la mastoides, el mentón, y la línea nucal del occipital que podemos codificar con 1,2, claramente compatibles con el género femenino.

\section{Diagnóstico de la edad}

En cuanto a los datos obtenidos de la valoración morfológica de la metamorfosis que sufre con la evolución de la edad la unión de la cuarta costilla con la unión condral, por el método Iscan-Loth podemos valorar que el canal tiene siempre forma de U, alargado con espículas siempre más largas y delgadas. Hueso ligero, frágil y poroso. Datos que hacen compatible si comparamos con los moldes estandarizados con la fase $7(7 \mathrm{a}-7 \mathrm{~b})$, con mujer de 59-71 años.

Se unen a este método los hallazgos degenerativos múltiples que son propios de sujetos de avanzada edad, osteofitos vertebrales, osteofitos y artrosis en metacarpianos.

Diagnóstico de la talla

Valorando la longitud de los huesos largos medidos, podemos estimar un rango de la estatura, para ello recordamos las medidas:

_ Longitud del húmero: $297 \mathrm{~mm}$.

Se estima con las tablas habituales Manouvrier, Krogman, Telka, Trotter y Gleser, etc., un rango de talla de entre 150 y $155 \mathrm{~cm}$. 


\section{Hallazgos paleopatológicos}

1. En las tres piezas dentales estudiadas se observa un grado de desgaste de hasta $5++$ en la escala de Brothwell, con gran lesión periodontal con exposición de toda la raíz de la pieza 36, más de $10 \mathrm{~mm}$ de pérdida de inserción ósea; hay formación de dentina secundaria e incremento de aposición de cemento radicular.

2. Se aprecian múltiples focos de degeneración articular vertebrales y en los metatarsianos.

3. Se aprecian marcadores de actividad osteomuscular fundamentalmente a nivel diafisario del húmero; se evidencian relieves y asperezas en la cortical con crestas y depresiones, algunas de estas asperezas son propias de periostitis con rugosidad en los bordes diafisarios. Estos hallazgos son valorados por los criterios Hawkey y Merbs con R3. También vemos signos semejantes en el rodete de la cavidad glenoidea en los restos escapulares. 


\section{TUMBA-XIII}

\section{Inventario}

ESQUELETO CRANEAL

\begin{tabular}{|c|c|c|c|}
\hline \multicolumn{5}{|c|}{ Tumba XIII Caja 1294 } \\
\hline Hueso & dcho. & impar & izdo. \\
\hline Frontal & & 3 & \\
Parietal & 3 & & 3 \\
Occipital & & 3 & \\
Temporal & 3 & & 3 \\
Zigomático & 3 & & 3 \\
Palatino & 3 & & 3 \\
Maxil. sup. & 3 & & 3 \\
Nasal & & 3 & \\
Etmoides & & 3 & 3 \\
Lacrimal & 3 & & 3 \\
Vómer & & 3 & \\
Esfenoides & & 3 & \\
M. cuerpo & 3 & & 3 \\
M. rama & 3 & & \\
\hline
\end{tabular}

INVENTARIO DENTAL

\begin{tabular}{|c|c|c|c|}
\hline \multicolumn{4}{|c|}{ Tumba XIII FÓRMULA F. D. I. } \\
\hline pieza & dcho. & pieza & izdo. \\
\hline 11 & 3 & 21 & 1 \\
12 & 3 & 22 & 3 \\
13 & 3 & 23 & 1 \\
14 & 3 & 24 & 3 \\
15 & 3 & 25 & 3 \\
16 & 3 & 26 & 3 \\
17 & 3 & 27 & 3 \\
18 & 3 & 28 & 3 \\
\hline \multicolumn{4}{|c|}{ mandíbula } \\
\hline pieza & dcho. & pieza & izdo. \\
\hline 41 & 3 & 31 & 3 \\
42 & 3 & 32 & 3 \\
43 & 3 & 33 & 3 \\
44 & 3 & 34 & 3 \\
45 & 3 & 35 & 3 \\
46 & 3 & 36 & 3 \\
47 & 3 & 37 & 3 \\
48 & 3 & 38 & 3 \\
\hline
\end{tabular}

INVENTARIO POSCRANEAL

\begin{tabular}{|c|c|c|c|}
\hline \multicolumn{3}{|c|}{ Tumba XIII Caja 1294 } \\
\hline Hueso & dcho. & impar & $i z d o$. \\
\hline Hioides & & 3 & \\
Clavícula & 1 & & 2 \\
Omoplato & 2 & & 3 \\
Húmero & 1 & & 2 \\
Radio & 1 & & 2 \\
Cúbito & 1 & & 2 \\
Mano & 2 & & 2 \\
M. esternal & & 2 & \\
Mesoesternón & & 2 & \\
Costillas & 2 & & 2 \\
Atlas & & 1 & \\
Axis & & 2 & \\
C. 3 a 7 & & 2 & \\
D. 1 a 12 & & 2 & \\
L. 1 a 5 & & 2 & \\
Sacro & & 2 & \\
Ilión & 2 & & \\
Pubis & 2 & & \\
Isquión & 2 & & \\
Fémur & 1 & & \\
Rótula & 1 & & \\
Tibia & 1 & & \\
Peroné & 1 & & \\
Calcáneo & 1 & & \\
Astrágalo & 1 & & \\
Pie & 2 & & \\
\hline
\end{tabular}




\section{Antropometría}

\section{Extremidad superior:}

\begin{tabular}{|l|l|c|}
\hline \multicolumn{3}{|c|}{ Clavícula: Tumba XIII Caja 1294 } \\
\hline Hemilado izdo. & \multicolumn{1}{|c|}{ Medida } & $\mathrm{mm}$ \\
\hline & Long. máx. & 73,00 \\
& Perímetro centro & 34,00 \\
& Anch. ext. & 9,00 \\
& Anch. int. & 15,00 \\
\hline & \multicolumn{1}{|c|}{ Índices } & \\
\hline & Robustez & 46,58 \\
\hline
\end{tabular}

\begin{tabular}{|l|l|c|}
\hline \multicolumn{3}{|c|}{ Escápula: Tumba XIII Caja 1294 } \\
\hline Hemilado izdo. & \multicolumn{1}{|c|}{ Medida } & $\mathrm{mm}$ \\
\hline \multirow{5}{*}{} & Longitud máx. estimada & 122,00 \\
& Anchura máx. estimada & 70,00 \\
& Longitud máx. espina & - \\
& Longitud del borde lateral & - \\
& Longitud máx. de la coracoides & 91,00 \\
& Longitud máx. de la glenoidea & 27,00 \\
& Anchura máx. de la glenoidea & 17,00 \\
\hline & \multicolumn{1}{|c|}{ Índices } & \\
\hline & Escapular & 57,38 \\
& Glenoideo & 62,96 \\
\hline
\end{tabular}

\begin{tabular}{|c|c|c|}
\hline \multicolumn{3}{|c|}{ Radio: Tumba XIII Caja 1294} \\
\hline Hemilado dcho. & Medida & $\mathrm{mm}$ \\
\hline & Long. máx. & 197,00 \\
\hline & Long. fisiol. & 191,00 \\
\hline & Perímetro mín. & 31,00 \\
\hline & Perímetro mitad & 38,00 \\
\hline & Perímetro cabeza & 64,00 \\
\hline & Diámetro máx. cabeza & 15,00 \\
\hline & Diámetro mín. cabeza & 14,00 \\
\hline & Perímetro tuber. delt. & 43,00 \\
\hline & Diámetro trans. tuber. delt. & 9,00 \\
\hline & Diámetro trans. mitad & 5,00 \\
\hline & Diámetro ant. post mitad & 9,00 \\
\hline & Anch. epif. distal. & 24,00 \\
\hline & Índices & \\
\hline & Robustez & 15,74 \\
\hline & Diafisario & 93,33 \\
\hline
\end{tabular}

\begin{tabular}{|c|c|c|}
\hline \multicolumn{3}{|c|}{ Húmero: Tumba XIII Caja 1294} \\
\hline Hemilado dcho. & Medida & $\mathrm{mm}$ \\
\hline & Long. máx. & 263,00 \\
\hline & Long. fisio. & 259,00 \\
\hline & Perímetro mín. & 54,00 \\
\hline & Perímetro mitad & 59,00 \\
\hline & Diámetro máx. mitad & 15,00 \\
\hline & Diámetro mín. mitad & 11,00 \\
\hline & Anch. ep. distal. & 45,00 \\
\hline & Diámetro vert cabeza & 31,00 \\
\hline & Diámetro horizontal cabeza & 32,00 \\
\hline & Anch. sup. art. & 32,00 \\
\hline & Profud. troclea & 18,00 \\
\hline & Diámetro borde lat. troclea & 12,00 \\
\hline & Anch. condilo & 11,00 \\
\hline & Alt. condilo & 12,00 \\
\hline & Anch. máx. epitroclea & 16,00 \\
\hline & Diámetro ap. mín. epitroclea & 11,00 \\
\hline & Anch. fosa olecran. & 18,00 \\
\hline & Diámetro bord. ext. fosa olecra. & 9,00 \\
\hline & Diámetro bord. int. fosa olecra. & 11,00 \\
\hline & Anch. cabeza. & 37,00 \\
\hline & Índices & \\
\hline & Robustez & 22,43 \\
\hline & Diafisario & 73,33 \\
\hline
\end{tabular}

\begin{tabular}{|l|l|c|}
\hline \multicolumn{3}{|c|}{ Cúbito: Tumba XIII Caja 1294} \\
\hline Hemilado dcho. & \multicolumn{1}{|c|}{ Medida } & $\mathrm{mm}$ \\
\hline & Long. máx. & 214,00 \\
& Long. fisiol. & 211,00 \\
& Perímetro mín. & 30,00 \\
& Perímetro mitad & 38,00 \\
& Diámetro ap. subsigmoideo & 14,00 \\
& Diámetro transverso subsigmoideo & 11,00 \\
& Diámetro máx. mitad & 9,00 \\
& Diámetro mín. mitad & 5,00 \\
& Anchu. epífisis distal & 9,00 \\
& Altura coronoides & 190,00 \\
\hline & \multicolumn{2}{|c|}{ Índices } \\
\hline & Robustez & 2,34 \\
& Platolemia & 55,56 \\
\hline
\end{tabular}




\section{Extremidad inferior:}

\begin{tabular}{|l|c|}
\hline \multicolumn{2}{|c|}{ Sacro: Tumba XIII Caja 1294 } \\
\hline Medida & $\mathrm{mm}$ \\
\hline Altura máx. & 105,00 \\
Anchura máx. & 102,00 \\
Profundidad & 33,00 \\
\hline \multicolumn{1}{|c|}{ Índices } & \\
\hline Hiérico & 97,14 \\
\hline
\end{tabular}

\begin{tabular}{|l|l|c|}
\hline \multicolumn{2}{|c|}{ Coxal: Tumba XIII Caja 1294 } \\
\hline Hemilado Dcho. & \multicolumn{1}{|c|}{ Medida } & $\mathrm{mm}$ \\
\hline & Altura total & 166,00 \\
& Anch. máx. del ileón & 128,00 \\
& Diámetro menor del ileón & 87,00 \\
& Long. carilla auricular & 44,00 \\
& Diámetro isqueopúbico máx. & - \\
& Longitud del pubis & \\
& Diámetro de la cav. cotiloidea & 37,00 \\
& Ángulo subpúbico & 120,00 \\
\hline
\end{tabular}

\begin{tabular}{|l|l|c|}
\hline \multicolumn{3}{|c|}{ Rótula: Tumba XIII Caja 1294 } \\
\hline Hemilado dcho. & \multicolumn{1}{|c|}{ Medida } & $\mathrm{mm}$ \\
\hline & Alt. máx. & 26,00 \\
& Anch. max & 28,00 \\
& Espesor máx. & 11,00 \\
\hline & \multicolumn{1}{|c|}{ Ídices } & \\
\hline & Rotuliano & 92,86 \\
\hline
\end{tabular}

\begin{tabular}{|l|l|c|}
\hline \multicolumn{2}{|c|}{ Fémur: Tumba XIII Caja 1294 } \\
\hline Hemilado Izdo. & \multicolumn{1}{|c|}{ Medida } & $\mathrm{mm}$ \\
\hline & Long. máx.-Estimada & 378,00 \\
& Long. fisiol. & 376,00 \\
& Perímetro mitad & 71,00 \\
& Diámetro ap. mitad & 19,00 \\
& Diámetro trans. mitad & 20,00 \\
& Diámetro trans. subtrocantero & 23,00 \\
& Diámetro ap. subtrocantero & 17,00 \\
& Anch. epífisis distal & 59,00 \\
& Diámetro vertical de la cabeza & 33,00 \\
& Diámetro horizontal de la cabeza & 33,00 \\
\hline & \multicolumn{2}{|c|}{ Índices } \\
\hline & Robustez & 18,78 \\
& Pilástrico & 95,00 \\
& Mérico & 73,91 \\
\hline
\end{tabular}

\begin{tabular}{|l|l|c|}
\hline \multicolumn{3}{|c|}{ Peroné: Tumba XIII Caja 1294 } \\
\hline Hemilado izdo. & \multicolumn{1}{|c|}{ Medida } & $\mathrm{mm}$ \\
\hline & Long. máx. & 292,00 \\
& Perímetro mín. & 28,00 \\
& Perímetro mitad & 35,00 \\
& Diámetro máx. mitad. & 6,00 \\
& Diameto min. mitad & 5,00 \\
& Anch. epif. distal. & 16,00 \\
\hline & \multicolumn{1}{|c|}{ Índices } & \\
\hline & Robustez & 9,59 \\
& Diáfisis & 83,33 \\
\hline
\end{tabular}

\begin{tabular}{|l|l|c|}
\hline \multicolumn{3}{|c|}{ Tibia: Tumba XIII Caja 1294 } \\
\hline Hemilado izdo. & \multicolumn{1}{|c|}{ Medida } & $\mathrm{mm}$ \\
\hline & Long. máx. & 293,00 \\
& Perímetro mín. & 63,00 \\
& Perímetro mitad & 69,00 \\
& Perímetro a aguj. nutric. & 75,00 \\
& Diámetro trans. aguj. nutric. & 15,00 \\
& Diámetro ap. aguj. nutric. & 24,00 \\
& Diámetro trans. mitad & 13,00 \\
& Diámetro ap. mitad & 21,00 \\
& Anchura epífisis distal & 40,00 \\
& Anchura epífisis próx. & 59,00 \\
& Long. art. condilo medial & 33,00 \\
& Anch. art. condilo medial & 20,00 \\
& Long. art. condilo lateral & 25,00 \\
& Anch. art. condilo lateral & 20,00 \\
\hline & & \\
\hline & Índices & 61,9 \\
& Cnemico & 52,5 \\
\hline
\end{tabular}




\section{Odontoscopia y Odontometría}

\begin{tabular}{|c|c|c|}
\hline & SUELTO & SUELTO \\
\hline Identificación & 355 & 356 \\
\hline $\mathrm{N} .^{\circ}$ de diente & 23 & 21 \\
\hline Diámetro $\mathrm{m}-\mathrm{d}(\mathrm{mm})$ & 7,6 & 8,3 \\
\hline Diámetro v-l (mm) & 7,4 & 5,7 \\
\hline N. ${ }^{\circ}$ de cúspides & & \\
\hline Características 1 & & \\
\hline Características 2 & & \\
\hline Anomalías 1 & DESG. & DESG. \\
\hline Anomalías 2 & & \\
\hline Caries tipo & & III mes \\
\hline Cálculo & + & + \\
\hline Les. periodontal $(\mathrm{mm})$ & & \\
\hline Esc. Brothwell & 3 & $3+$ \\
\hline Criterios de Gustafson & & \\
\hline Atricción & 2 & 2 \\
\hline Enf. periodontal & & \\
\hline Dentina secundaria & 1 & 1 \\
\hline
\end{tabular}

\section{Antroposcopia}

Se trata de unos restos óseos limpios, consolidados, bien conservados. Se muestran porosos y muy frágiles. Se aprecian signos degenerativos.

\section{Estudio radiológico}

Se realizan tanto placas periapicales de las dos piezas sueltas estudiadas y placas de mamografía especialmente en las clavículas para evidenciar una probable fractura antigua, así como en los coxales para evidenciar las osificaciones degenerativas en forma de exostosis o pequeñas espinas a nivel ilíaco.

\section{Diagnóstico del sexo}

Fundamentalmente, al faltar estructuras craneales, los patrones de dimorfismo sexual empleados son la valoración antroposcópica del coxal; destacamos escotadura ciática abierta y marcada, fosas ilíacas más marcadas, cavidad cotiloidea menos marcada, agujero obturador triangular. Se le suma la superficie y la morfología auricular método de Iscan y Derried: compatible con el género femenino. 
- Surco preauricular: parte inferior de la superficie auricular. Profundo, extenso y ancho.

- Espacio posauricular: ancho.

- Tuberosidad ilíaca: variada (pero no ondulada).

El sacro corto y la carilla auricular no superan la 2. ${ }^{a}$ vértebra sacra. También orientador del género femenino.

Este diagnóstico se complementa con las dimensiones de los huesos largos en especial las medidas de la cabeza femoral de $33 \mathrm{~mm}$.

Diagnóstico de la edad

Estudio morfológico de la metamorfosis que sufre con la evolución de la edad la unión de la cuarta costilla con la unión condral, valorado este método encontramos canal en forma de $U$ alargada. La pared adelgazada, aumentando las irregularidades de los márgenes. El hueso más frágil y poroso compatible con fase $4(\mathrm{~m} 4 \mathrm{~b})$ según Iscan-Loth comparando con moldes estandarizados, equivalente a una edad estimada de una mujer de 33-46 años.

Diagnóstico de la talla

Valorando la longitud de los huesos largos medidos, podemos estimar un rango de la estatura, para ello recordamos las medidas:

- Longitud del húmero: $263 \mathrm{~mm}$.

- Longitud del radio: $197 \mathrm{~mm}$.

- Longitud del cúbito: $214 \mathrm{~mm}$.

- Longitud del fémur: $378 \mathrm{~mm}$.

- Longitud del peroné: $292 \mathrm{~mm}$.

- Longitud de la tibia: $293 \mathrm{~mm}$.

Se estima con las tablas habituales Manouvrier, Krogman, Telka, Trotter y Gleser, etc., un rango de talla de entre 140 y $150 \mathrm{~cm}$.

\section{Hallazgos paleopatológicos}

1. Se aprecia el desgaste dental en las dos piezas estudiadas con grado entre 3 y $3+$ de la escala de Brothwell, presencia de sarro y caries tipo III mesial en la pieza 21. 
2. En la clavícula derecha se aprecia su tercio interno deformado con callo hipertrófico y desviado; en la radiografía se aprecia una imagen compatible con fractura antigua.

3. Marcadores de actividad osteomuscular:

- En la corredera bicipital se aprecia un marcado canal profundo. Aparecen hoyos o craterizaciones. A nivel diafisario del húmero se evidencian relieves y asperezas en la cortical con crestas y depresiones, algunas de estas asperezas son propias de periostitis con rugosidad en los bordes diafisarios. Estos hallazgos son valorados por los criterios Hawkey y Merbs, expuestos con anterioridad con R3.

- En la cresta ilíaca de algunas de las tumbas estudiadas se aprecian en los bordes insercionales excrecencias y rugosidades junto con pequeñas exostosis (S3, Os2). Se aprecia una auténtica espina ósea osificada de más de $12 \mathrm{~mm}$ que debe ser valorada claramente como Os3, según los criterios expuestos con anterioridad.

- A nivel del fémur en la cara posterior y la línea áspera se aprecia un marcado relieve con aspereza muy marcada, son valoradas como R3 y S3.

- A nivel tibial es de destacar en la epífisis proximal y, concretamente, en la tuberosidad tibial anterior signos de periostitis con estriaciones y depresiones junto con hoyos profundos y extensos (más de $3 \mathrm{~mm}$ de profundidad y $5 \mathrm{~mm}$ de superficie) en superficie que nos obligan a valorar con los criterios de Hawkey y Merbs como R3 y S3; además, estos hallazgos serían compatibles con enfermedad de Osgood-Schlatter.

- En la epífisis proximal del fémur de la carilla de Poirier. Esta impresión cervical es considerada por algunos autores una variación discontinua (Finnegan, 1978) asociada al sexo y con interdependencia de lado (Donlon, 2000). Sin embargo, otros la consideran más bien un indicador de postura en cuclillas (Kennedy, 1989); o un signo de locomoción, tanto normal como de grandes caminatas por terrenos accidentados (Capasso et al., 1998), debido a que el contacto de la cabeza femoral y el borde del acetábulo se produce por la extrema flexión y abducción del fémur. 
- En la epífisis distal del fémur, concretamente a nivel del condilo externo, se aprecia una fosa muy marcada para inserciones musculares (R3).

- Epífisis distal de la tibia: carilla lateral de acuclillamiento; se aprecia como una carilla deprimida, casi un surco, nos orienta a pensar en el acuclillamiento o marcha prolongada por terrenos irregulares.

- En la cara anterior de la rótula se aprecian estriaciones y marcas generadas por la impronta del tendón rotuliano, no con la profundidad y la extensión de otras localizaciones S2; junto a ello un saliente óseo exostósico degenerativo (Os 3).

- En la cara posterior del calcáneo se aprecian excrecencias y estriaciones interpuestas reflejando la acción de robustos en todos los casos estudiados; la valoración con los criterios utilizados debe estimarse con S3. 


\section{Cenizas del bustum}

\section{Valoración antroposcópica}

Se trata de unos restos y fragmentos óseos fragmentados. Estos huesos están frágiles y con distinta coloracion por la acción del fuego. Por el color blanquecino en muchos de los restos, podemos afirmar que existe una exposición prolongada al calor, en algún caso tienen una apariencia de cerámica por la calcinación que han sufrido.

Se aprecian líneas de fractura longitudinales y transversales por efecto de la torsión; por el estudio de estas líneas de fractura podemos reconocer partes de las diáfisis de algunos huesos largos femorales con líneas de fractura curvas, humerales, líneas transversales y longitudinales y a saltos transversales en las costillas. También apreciamos restos de la esponjosa de una epífisis que podría corresponder a la epífisis superior de la tibia.

No se puede determinar con exactitud el sexo, la edad, ni otros datos con tan escasos fragmentos óseos. El estudio de la cámara pulpar de la pieza dental hallada nos orienta hacia una edad al morir de un sujeto joven menor de 20 años, cuestión compatible con las edades encontradas en otras tumbas. 


\section{Conclusiones}

Primera: la Tumba I corresponde a una niño varón de 2 a 4 años de edad al morir y con una talla aproximada de 80 a $90 \mathrm{~cm}$.

Segunda: la Tumba III corresponde a un varón de 24 a 28 años de edad al morir y con una talla de 160 a $170 \mathrm{~cm}$.

Tercera: la Tumba IV corresponde a un varón de 24 a 28 años o de 18,5 $\pm 2,1$ años, de edad al morir según el método empleado, y de talla aproximada de 163 a $173 \mathrm{~cm}$.

Cuarta: la Tumba V se trata de feto de un varón de 28 a 32 semanas de gestación de edad al morir, y con una talla aproximada de $37 \mathrm{a} 44 \mathrm{~cm}$.

Quinta: la Tumba VI corresponde a un niño varón, feto a término o muerte perinatal \pm 2 meses de edad al morir y con una talla estimada de entre los $47 \mathrm{y} \operatorname{los} 52 \mathrm{~cm}$.

Sexta: la Tumba VII corresponde a un varón de 20 a 23 años de edad al morir y con una talla aproximada de 160 a $165 \mathrm{~cm}$.

Séptima: la Tumba VIII corresponde a una varón de 24 a 28 años de edad al morir y de talla estimada de 155 a $165 \mathrm{~cm}$.

Octava: la Tumba IX corresponde a un varón de 26 a 32 años de edad al morir y con una talla aproximada de 160 a $170 \mathrm{~cm}$.

Novena: la Tumba X corresponde a una mujer de 33 a 46 años de edad al morir y con una talla estimada de 145 a $155 \mathrm{~cm}$.

Décima: la Tumba XI corresponde a un varón de 24 a 28 años de edad al morir y con una talla aproximada de 168 a $172 \mathrm{~cm}$.

Undécima: la Tumba XII corresponde a una mujer de 59 a 71 años de edad y con una talla estimada de 150 a $155 \mathrm{~cm}$.

Duodécima: la Tumba XIII corresponde a una mujer de 33 a 46 años de edad al morir y con una talla aproximada de 140 a $150 \mathrm{~cm}$.

Decimotercera: los varones adultos jóvenes presentan marcados signos de estrés o actividad osteomuscular valorados con los criterios de Hawkey y Merbs en sus máximos grados. 
Decimocuarta: a nivel de la extremidad superior en los adultos jóvenes se aprecian marcadores osteomusculares relacionados con la carga de pesos y/o el lanzamiento de objetos, asi como desplazamiento de vaivén del miembro hacia atrás y al pecho opuesto.

Decimoquinta: a nivel de la extremidad inferior los adultos jóvenes presentan marcadores osteomusculares relacionados con marcha prolongada, largos periodos de bipedestación, tránsito por una accidentada orografía y con mantener el equilibrio individual en condiciones inestables, realizar largas caminatas por terrenos muy accidentados y al frecuente impacto del pie sobre el suelo, continuados esfuerzos tensionales, como, por ejemplo, torceduras.

Decimosexta: en las tumbas de adultos se encuentran a nivel odontológico signos de importante desgaste dental y enfermedad periodontal según las escalas habituales.

Decimoséptima: por el estudio odontomorfológico del desgaste dental encontrado, el factor etiológico predominante es el bruxismo por estrés. 


\section{Bibliografía utilizada}

BASS, W. M. (1986), Human Osteology: A Laboratory and field Manual of the Human Skeleton. Columbia, Missouri. Missouri Arch. Society, Special Public. No. 2.

Brothwell, D. R. (1987), Desenterrando huesos. La excavación, tratamiento y estudio de restos del esqueleto humano. Fondo de Cultura Económica. Méjico.

Dutour, O. (1986), «Enthesopathies (lesions of muscular insertions) as indicators of the activities of neolithic Saharan populations». Am. J. Phys. Anthropol. Oct; 71 (2): 221-224.

EsTÉVEZ, M. C. (2002), Marcadores de estrés y actividad en la población guanche de Tenerife. Tesis doctoral. Universidad de La Laguna.

HAWKEY D. E. (1988), Use of upper extremity enthesopathies to indicate habitual activity patterns. MA Thesis, Arizona State Univ., Tempe, AZ.

- y C. F. Merbs (1995), «Activity-induced musculoskeletal stress markers (MSM) and subsistence strategy changes among ancient Hudson Bay Eskimos». Int. J. Osteoarchaeol., 5: 324-338.

IsCan, M. Y. (ed.) (1989), Age Markers in the Human Skeleton. Springfield, Illinois. Charles C. Thomas, Pub.

Krogman, W. M, y M. Y. IsCAN (1986), The Human Skeleton in Forensic Medicine. Springfield, Illinois. Charles C. Thomas Pub.

Molnar, P. (2006), «Tracing prehistoric activities: musculoskeletal stress marker analysis of a Stone-Age population on the island of Gotland in the Baltic sea ». Am. J. Phys. Anthropol. 2006 Jan; 129 (1): 12-23.

PaOla, F. (2005), «Metodología para el registro de marcadores de estrés músculo esquelético». Boletín de Antropología. Año/Vol. 19, n. ${ }^{\circ} 36$. Universidad de Antioquia. Medellín. Colombia: 255-268.

Rовв, J. (1998), «The interpretation of skeletal muscle sites: an statistical approach». Int. J. Osteoarchaeol, 8: 363-377. 
Rodríguez, J. V. (1991), Introducción a la Arqueología Forense, cap. I / V. Anaconda Editores. Universidad Nacional de Bogotá-Santafé de Bogotá.

Rodríguez Martín, C., y M. Martín Oval (1997), «Marcadores esqueléticos de estrés ocupacional en la población guanche de Tenerife (Islas Canarias)». Eres (Arqueologia), 7 (1): 105-117.

SPERDUTI, A. (1997), «Life conditions of a roman Imperial age population: Occupational stress markers and working activities in Lucus feroniae (Rome, 1st2nd cent. AD)». Human evolution (Hum. evol.), vol. 12, n. ${ }^{\circ} 4$, pp. $253-267$ (3 p. 1/2).

Ubelaker, D. H. (1989), Human Skeletal Remains. Excavation, Analysis, Interpretation. Taraxacum-Washington, Smiths. Inst. Manuals on Archaeology 2. 

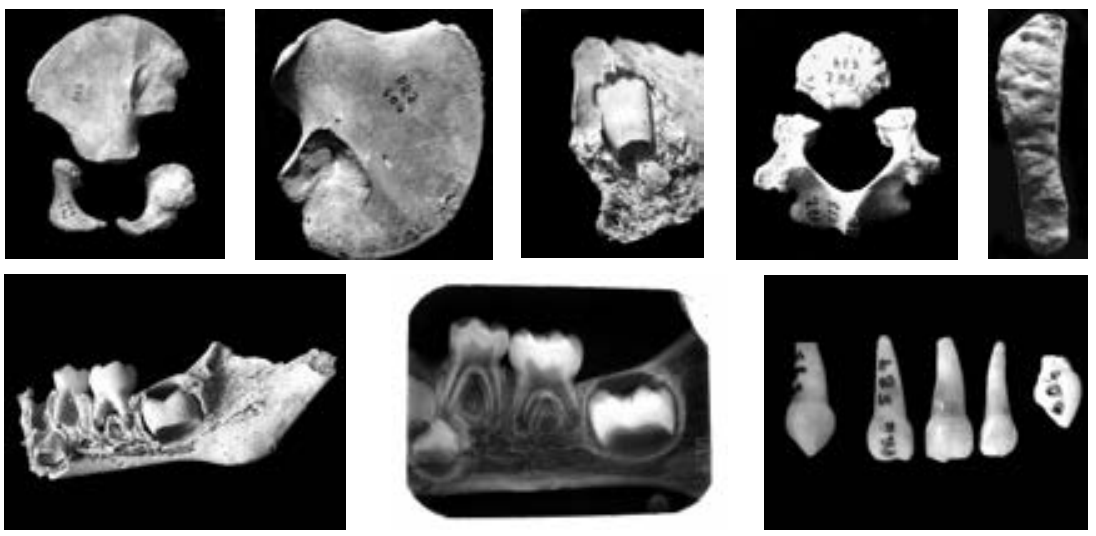

1. Coxal. 2. lleón. 3. Germen de diente incisivo inferior. 4. Vértebra sin fusionar. 5. Sínfisis de pubis. 6. Cara interna de la mandíbula derecha. 7. Rx. de la mandíbula derecha. 8. Dientes temporales superiores.

\section{TUMBA III}
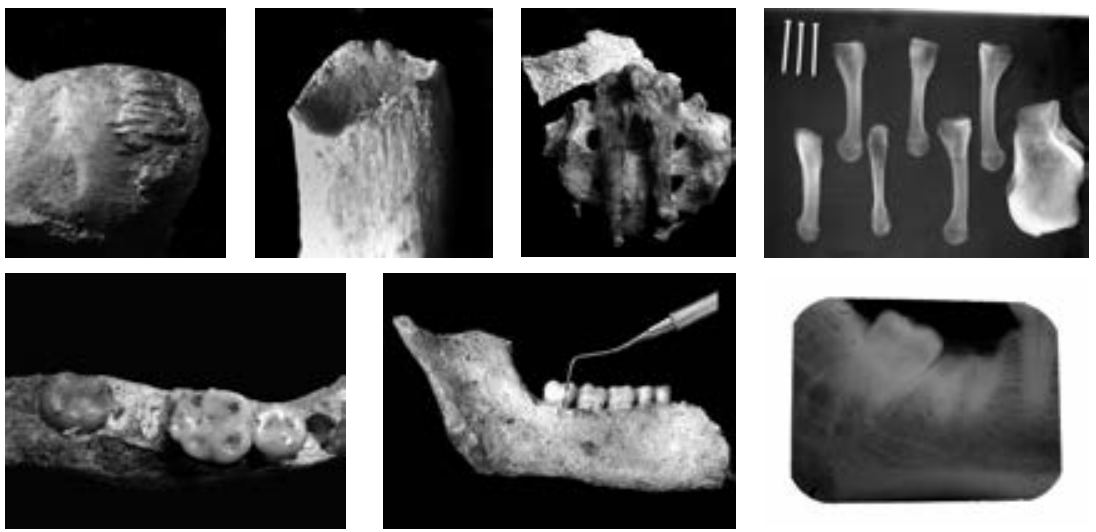

1. Calcáneo. 2. Costilla. 3. Sacro. 4. Rx. de metatarsianos y calcáneo. 5. Cara oclusal de los dientes de la mandíbula. 6. Lesión peridontal. 7. Inclinación mesial de la pieza 48. 

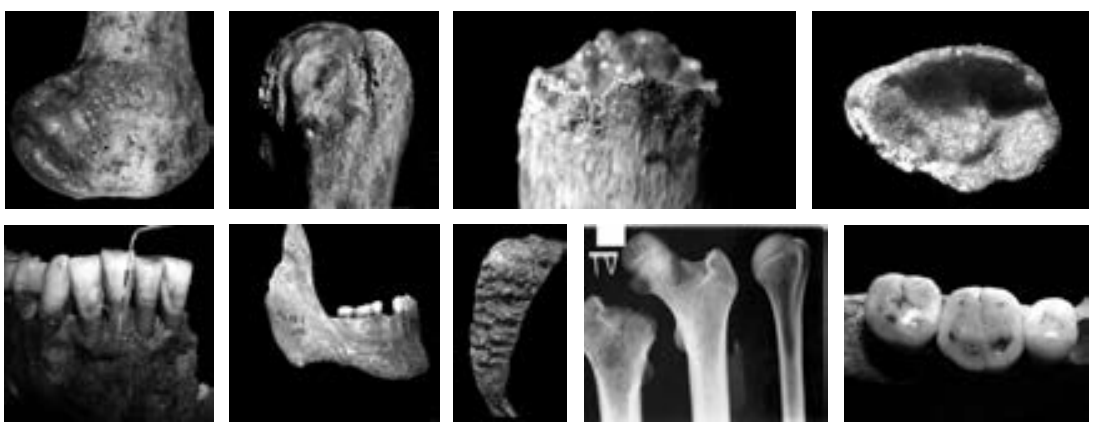

1. Fosa poplítea femoral. 2. Corredera bicipital. 3. Borde de costilla. 4. Costilla. 5. Lesión periodontal. 6. Mandíbula. 7. Sínfisis de pubis. 8. Rx. de los huesos largos. 9. Desgaste de la cara oclusal de dientes mandibulares.

\section{TUMBA $V$}
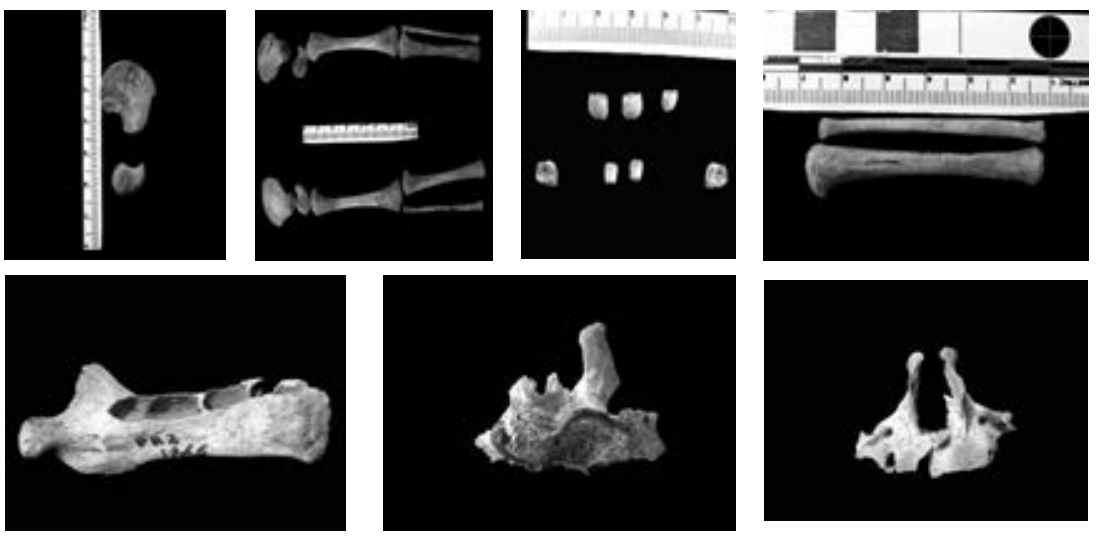

1. Coxal. 2. Extremidades inferiores. 3. Gérmenes de dientes temporales. 4. Tibia y peroné. 5. Mandíbula. 6. Maxilar superior izquierdo. 7. Maxilares superiores. 

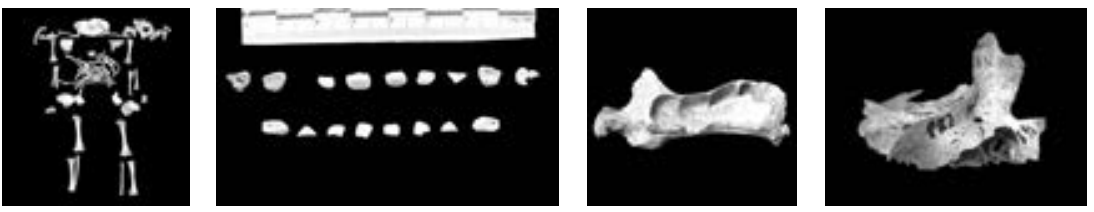

1. Esqueleto. 2. Gérmenes de dientes temporales. 3. Mandíbula. 4. Maxilar superior.
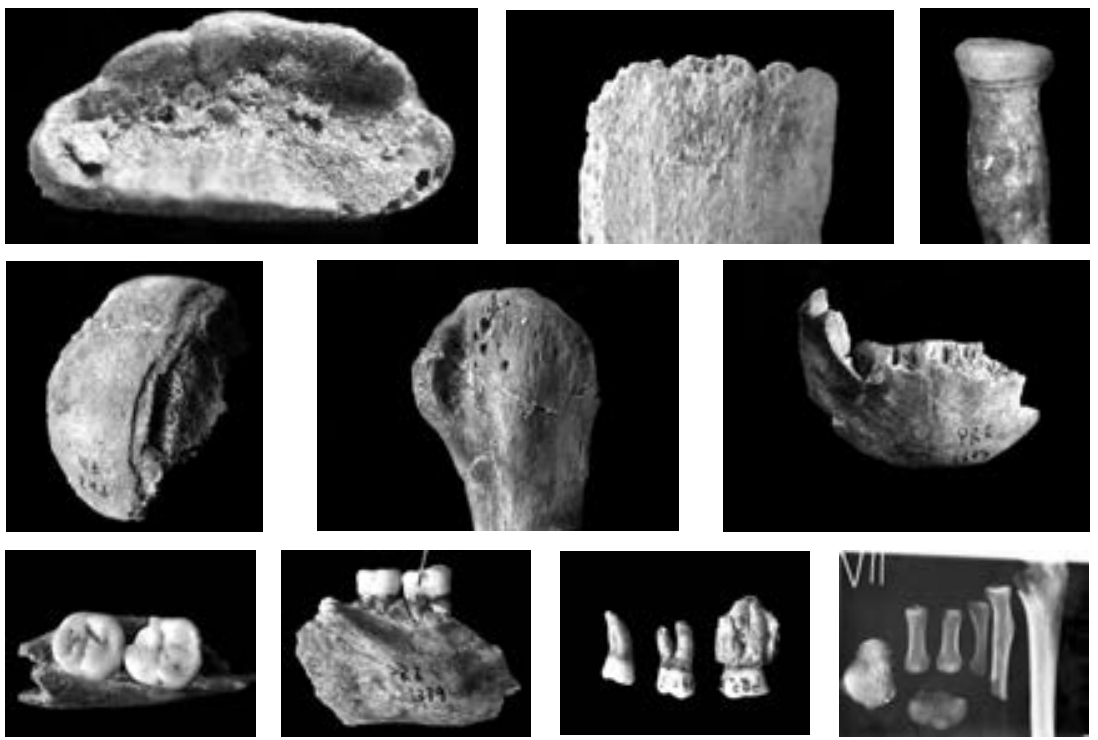

1. Cara anterior de costilla. 2. Perfil de costilla. 3. Radio. 4. Condilo femoral. 5. Húmero. 6. Mentón. 7. Desgaste caras oclusales. 8. Lesión periodontal en la pieza 47. 9. Piezas dentales 18-17-16. 10. Rx. de huesos. 

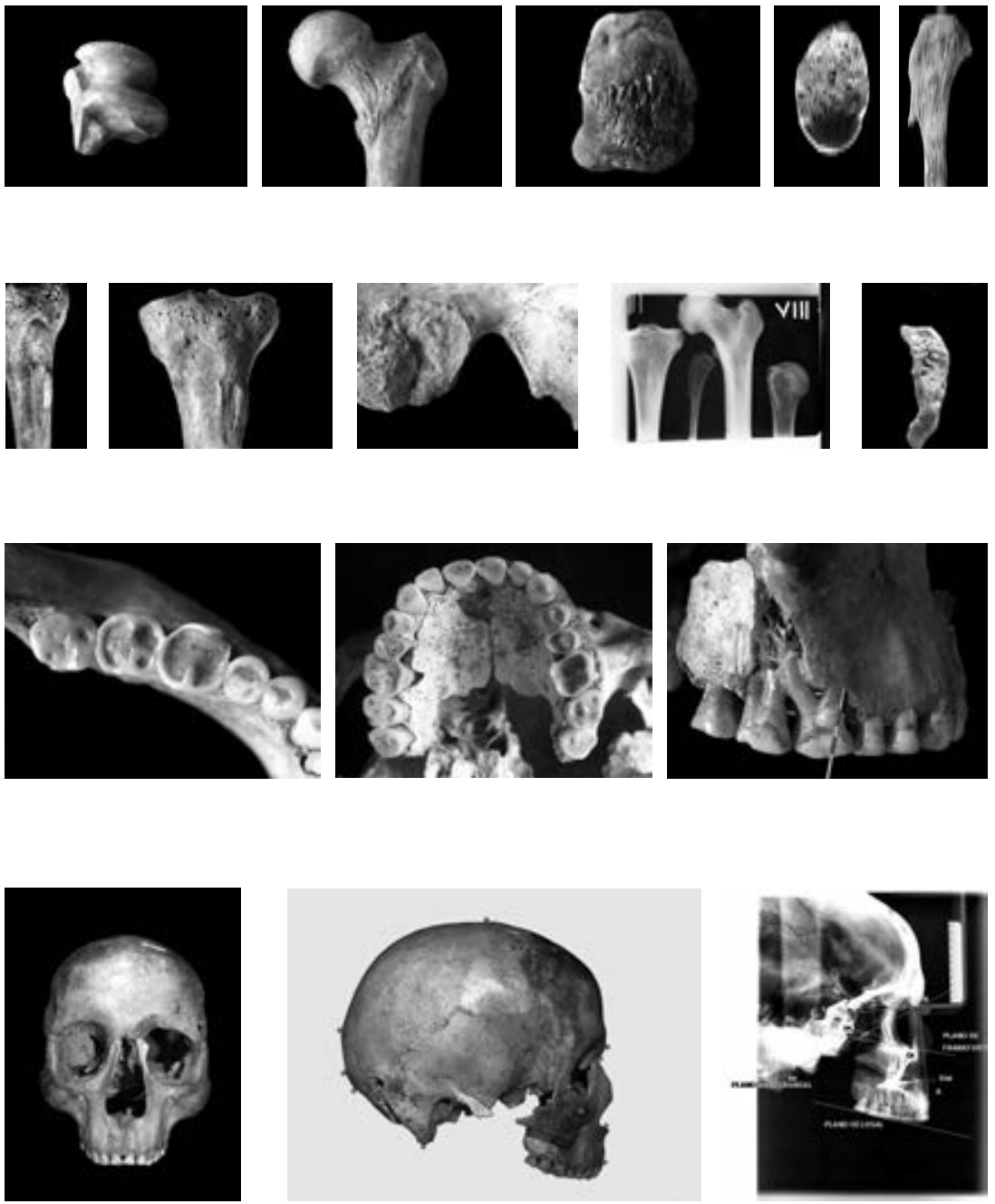

1. Astrágalo de caballo. 2. Cabeza de fémur. 3. Calcáneo. 4. Costilla. 5. Peroné. 6. Tibia. 7. Tibia. 8. Escotadura ciática. 9. Rx. de los huesos largos. 10. Sínfisis de pubis. 11. Desgaste oclusal de los molares en la mandíbula. 12. Desgaste oclusal en la arcada dental superior. 13. Lesión periodontal. 14. Cráneo. 15. Puntos craneométricos. 16. Cefalometría. 

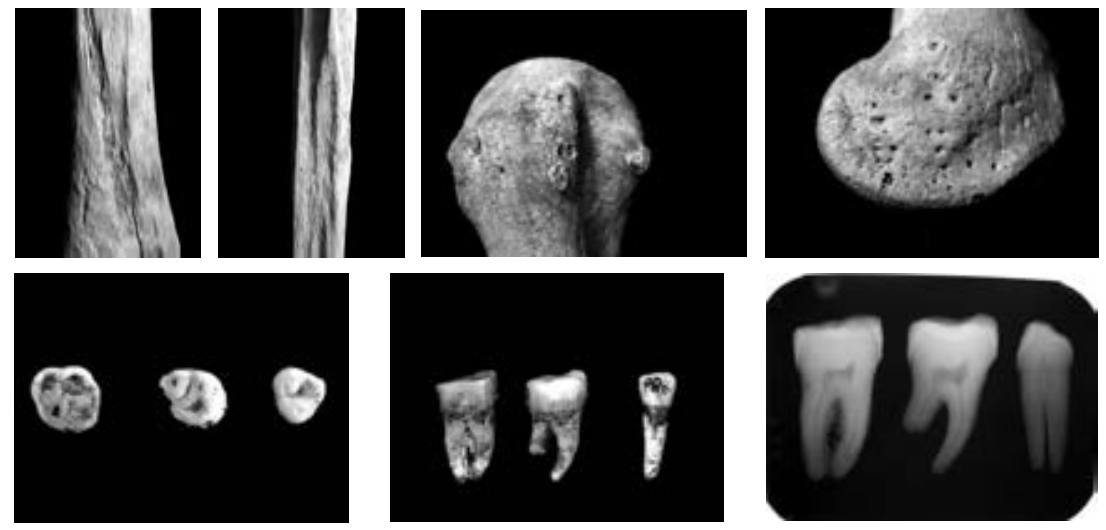

1. Periostitis humeral. 2. Periostitis del peroné. 3. Corredera bicipital profunda. 4. Craterización en el condilo femoral externo. 5. Desgaste de las caras oclusales. 6. Piezas dentales 47-46-44. 7. Rx de las piezas 47-46-44.

\section{TUMBA X}
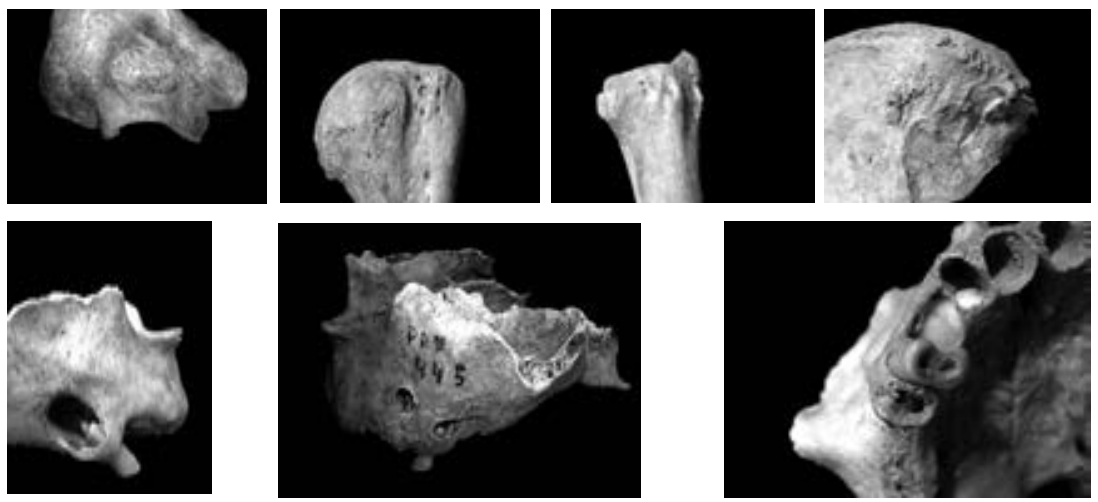

1. Húmero distal. 2. Húmero proximal. 3. Tubérculos dorsales del radio. 4. Marcada osificación en iliaco. 5. Absceso en el maxilar superior derecho. 6. Absceso en el maxilar superior izquierdo. 7. Canino superior derecho incluido. 

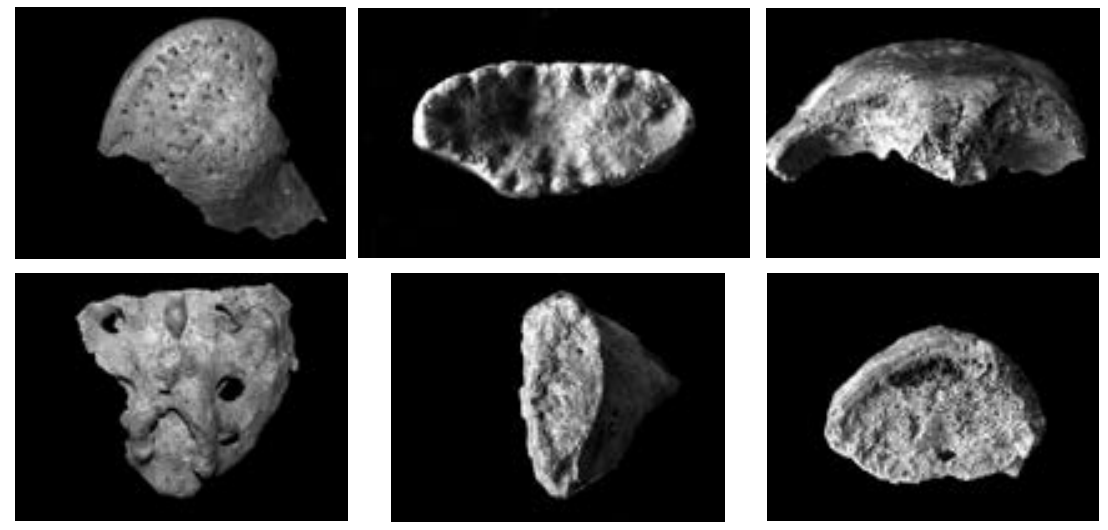

1. Condilo femoral. 2. Costilla. 3. Hueso frontal. 4. Sacro. 5. Sínfisis de pubis. 6. Vértebra.

\section{TUMBA XII}
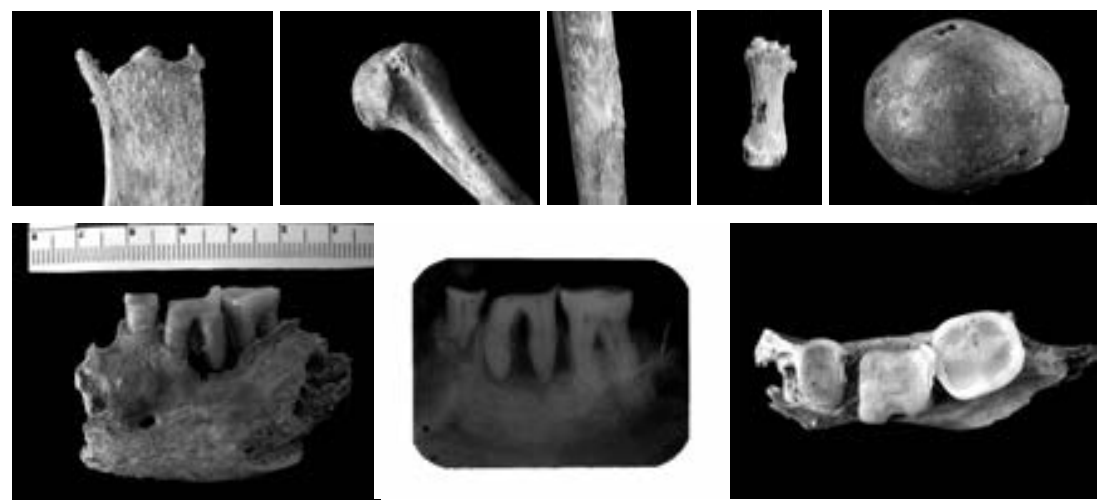

1. Costilla. 2. Húmero. 3. Periostitis humeral. 4. Metatarsiano. 5. Cráneo. 6. Lesión periodontal. 7. Rx de las piezas 35-36-37. 8. Desgaste oclusal de las piezas 35-36-37. 

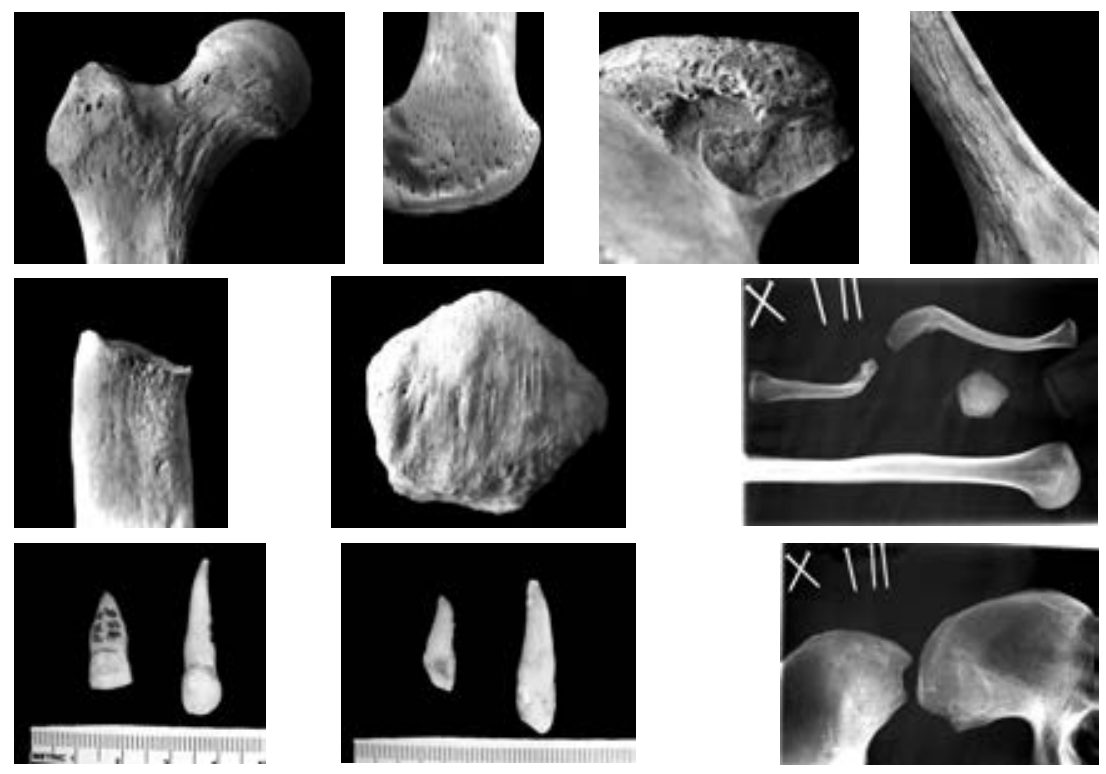

1. Cabeza de fémur. 2. Condilo femoral. 3. Cresta iliaca. 4. Periostitis humeral. 5. Costilla. 6. Rótula. 7. Rx de clavícula y húmero. 8. Cara vestibular de las piezas dentales 21 y 23. 9. Cara mesial de las piezas 21 y 23. Caries en la pieza 21. $10 \mathrm{Rx}$ de coxal.

\section{BUSTUM}
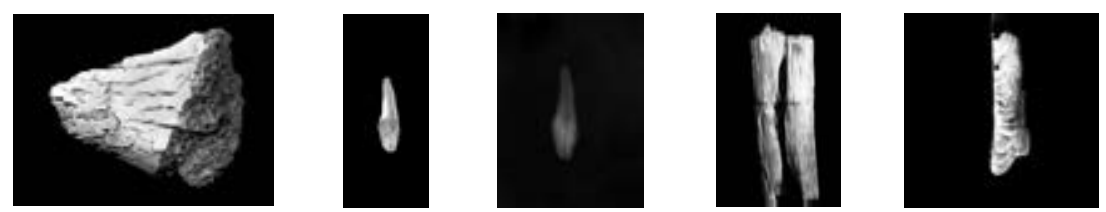

1. Esponjosa. 2. Diente incisivo. 3. Rx de diente incisivo. 4. Huesos largos. 5. Resto óseo. 



\section{ÍNDICE}

I. INTRODUCCIÓN AL PANORAMA FUNERARIO DE CAESARAUGUSTA

II. EL GRUPO FUNERARIO DEL SIGLO III ................................. 15

La excavación arqueológica .................................................................. 15

Análisis de las tumbas. Las incineraciones ....................................... 26

Análisis de las tumbas. Las inhumaciones ........................................... 44

III. EL MONUMENTO FUNERARIO. INCINERACIÓN I........ 87

IV. PRÁCTICAS FUNERARIAS Y OFRENDAS RITUALES .... 127

CONCLUSIÓN _................................................................................. 157

BIBLIOGRAFÍA _......................................................................................... 161

ANEXO: ESTUDIO ANTROPOLÓGICO DE RESTOS ÓSEOS .. 187 

Este libro se terminó de imprimir en los talleres gráficos

de INO Reproducciones, de Zaragoza, el día 11 de diciembre de 2008

$\operatorname{Cos}$ 



\section{Títulos de Ciencias Sociales}

1 Luis Gracia Martín, El actuar en lugar de otro en Derecho Penal (1985).

2 Antonio Serrano González, Michel Foucault: Sujeto, derecho, poder (1986).

3 Ignacio Peiró Martín y Gonzalo Pasamar Alzuria, Historiografía y práctica social en España (1987).

4 Fernando Pérez Cebrián, La planificación de la encuesta social (1987).

5 Yolanda Polo Redondo, Desarrollo de nuevos productos: aplicaciones a la economía española (1988).

6 Eloy Fernández Clemente, Estudios sobre Joaquin Costa (1988).

7 Gema Martínez de Espronceda Sazatornil, El canciller de bolsillo. Dollfuss en la prensa de la II República (1988).

8 José Ignacio Lacasta Zabalza, Cultura y gramática del Leviatán portugués (1988).

9 José M. ${ }^{a}$ Rodanés Vicente, La Prehistoria. Apuntes sobre concepto y método (1988).

10 Cástor Díaz Barrado, El consentimiento como causa de exclusión de la ilicitud del uso de la fuerza, en Derecho Internacional (1989).

11 Harvey J. Kaye, Los historiadores marxistas británicos. Un análisis introductorio (1989).

12 Antonio Beltrán Martínez, Ensayo sobre el origen y significación del arte prehistórico (1989).

13 José Luis Moreu Ballonga, El nuevo régimen jurídico de las aguas subterráneas (1990).

14 Santiago Míguez González, La preparación de la transición a la democracia en España (1990).

15 Jesús Hernández Aristu, Pedagogía del ser: aspectos antropológicos y emancipatorios de la pedagogía de Paulo Freire (1990).

16 Alfonso Sánchez Hormigo, Valentín Andrés Álvarez. (Un economista del 27) (1991).

17 José Antonio Ferrer Benimeli y Manuel A. de Paz Sánchez, Masonería y pacifismo en la España contemporánea (1991).

18 Gonzalo Pasamar Alzuria, Historiografía e ideología en la postguerra española: la ruptura de la tradición liberal (1991).

19 Sidney Pollard, La conquista pacifica. La industrialización de Europa, 1760-1970 (1991).

20 Jesús Lalinde Abadía, Las culturas represivas de la Humanidad (1992).

21 Fernando Baras Escolá, El reformismo político de Jovellanos. (Nobleza y poder en la España del siglo XVIII) (1993).

22 José Antonio Ferrer Benimeli (coord.), Masonería y periodismo en la España contemporánea (1993).

23 John Clanchy y Brigid Ballard, Cómo se hace un trabajo académico. Guía práctica para estudiantes universitarios, 2. ${ }^{\mathrm{a}}$ ed. (2000).

24 Eloy Fernández Clemente, Ulises en el siglo XX. Crisis y modernización en Grecia, 1900-1930 (1995).

25 Enrique Fuentes Quintana, El modelo de economía abierta y el modelo castizo en el desarrollo económico de la España de los años 90 (1995).

26 Alfred D. Chandler, Jr., Escala y diversificación. La dinámica del capitalismo industrial, traducción de Jordi Pascual (1996).

27 Richard M. Goodwin, Caos y dinámica económica, traducción y revisión técnica de Julio Sánchez Chóliz, Dulce Saura Bacaicoa y Gloria Jarne Jarne (1997). 
28 M. ${ }^{a}$ Carmen Bayod López, La modificación de las capitulaciones matrimoniales (1997).

29 Gregory M. Luebbert, Liberalismo, fascismo o socialdemocracia. Clases sociales y orígenes politicos de los regímenes de la Europa de entreguerras, traducción de Álvaro Garrido Moreno (1997).

30 Ángela Cenarro Lagunas, Cruzados y camisas azules. Los orígenes del franquismo en Aragón, 1936-1945 (1997).

31 Enrique Fuentes Quintana y otros, La Hacienda en sus ministros. Franquismo y democracia (1997).

32 Gaspar Mairal Buil, José Ángel Bergua Amores y Esther Puyal Español, Agua, tierra, riesgo y supervivencia. Un estudio antropológico sobre el impacto socio-cultural derivado de la regulación del río Ésera (1997).

33 Charles Tilly, Louise Tilly y Richard Tilly, El siglo rebelde, 1830-1930, traducción de Porfirio Sanz Camañes (1997).

34 Pedro Rújula, Contrarrevolución. Realismo y Carlismo en Aragón y el Maestrazgo, 1820-1840 (1998).

35 R.A.C. Parker, Historia de la segunda guerra mundial, traducción de Omnivox, S. L. (1998).

36 José Aixalá Pastó, La peseta y los precios. Un análisis de largo plazo (1868-1995) (1999).

37 Carlos Gil Andrés, Echarse a la calle. Amotinados, huelguistas y revolucionarios (La Rioja, 1890-1936) (2000).

38 Francisco Comín y otros, La Hacienda desde sus ministros. Del 98 a la guerra civil (2000).

39 Ángela López Jiménez, Zaragoza ciudad hablada. Memoria colectiva de las mujeres y los hombres (2001).

40 Juan Carmona, Josep Colomé, Juan Pan-Montojo y James Simpson (eds.), Viñas, bodegas y mercados. El cambio técnico en la vitivinicultura española, 1850-1936 (2001).

41 Ève Gran-Aymerich, El nacimiento de la arqueología moderna, 1798-1945, traducción de Inés Sancho-Arroyo (2001).

42 Rafael Vallejo Pousada, Reforma tributaria y fiscalidad sobre la agricultura y la propiedad en la España liberal, $1845-1900$ (2001).

43 Robert S. Duplessis, Transiciones al capitalismo en Europa durante la Edad Moderna, traducción de Isabel Moll (2001).

44 Carlos Usabiaga, El estado actual de la Macroeconomía. Conversaciones con destacados macroeconomistas, traducción de Montse Ponz (2002).

45 Carmelo Lisón Tolosana, Caras de España. (Desde mi ladera) (2002).

46 Hanneke Willemse, Pasado compartido. Memorias de anarcosindicalistas de Albalate de Cinca, 1928-1938, traducción de Francisco Carrasquer (2002).

47 M. ${ }^{a}$ Pilar Salomón Chéliz, Anticlericalismo en Aragón. Protesta popular y movilización politica (1900-1939) (2002).

48 Ana José Bellostas Pérez-Grueso, Carmen Marcuello Servós, Chaime Marcuello Servós y José Mariano Moneva Abadía, Mimbres de un país. Sociedad civil y sector no lucrativo en Aragón (2002). 
49 Mercedes Yusta Rodrigo, Guerrilla y resistencia campesina. La resistencia armada contra el franquismo en Aragón (1930-1952) (2003).

50 Francisco Beltrán Lloris (ed.), Antiqua Iuniora. En torno al Mediterráneo en la Antigüedad (2004).

51 Roberto Ceamanos Llorens, De la historia del movimiento obrero a la historia social. L'Actualité de l'Histoire (1951-1960) y Le Mouvement Social (1960-2000) (2004).

52 Carlos Forcadell, Gonzalo Pasamar, Ignacio Peiró, Alberto Sabio y Rafael Valls (eds.), Usos de la Historia y políticas de la memoria (2004).

53 Aitor Pérez Ruiz, La participación en la ayuda oficial al desarrollo de la Unión Europea. Un estudio para Aragón (2004).

54 Gloria Sanz Lafuente, En el campo conservador. Organización y movilización de propietarios agrarios en Aragón (1880-1930) (2005).

55 Francisco Comín, Pablo Martín Aceña y Rafael Vallejo (eds.), La Hacienda por sus ministros. La etapa liberal de 1845 a 1899 (2006).

56 Pedro Lains, Los progresos del atraso. Una nueva historia económica de Portugal, 18421992, traducción de Lourdes Eced (2006).

57 Alessandro Roncaglia, La riqueza de las ideas. Una historia del pensamiento económico, traducción de Jordi Pascual (2006).

58 Kevin H. O’Rourke y Jeffrey G. Williamson, Globalización e historia. La evolución de la economía atlántica en el siglo XIX, traducción de Montse Ponz (2006).

59 Fernando Casado Cañeque, La RSE ante el espejo. Carencias, complejos y expectativas de la empresa responsable en el siglo XXI (2006).

60 Marta Gil Lacruz, Psicología social. Un compromiso aplicado a la salud (2007).

61 José Ángel Bergua Amores, Lo social instituyente. Materiales para una sociología no clásica (2007).

62 Ricardo Robledo y Santiago López (eds.), ¿Interés particular, bienestar público? Grandes patrimonios y reformas agrarias (2007).

63 Concha Martínez Latre, Musealizar la vida cotidiana. Los museos etnológicos del Alto Aragón (2007).

64 Juan David Gómez Quintero, Las ONGD aragonesas en Colombia. Ejecución y evaluación de los proyectos de desarrollo (2007).

65 M. Alexia Sanz Hernández, El consumo de la cultura rural (2007).

66 Julio Blanco García, Historia de las actividades financieras en Zaragoza. De la conquista de Zaragoza (1118) a la aparición del Banco de Aragón (1909) (2007).

67 Marisa Herrero Nivela y Elías Vived Conte, Programa de Comprensión, Recuerdo y Narración. Una herramienta didáctica para la elaboración de adaptaciones curriculares. Experiencia en alumnos con sindrome de Down (2007).

68 Vicente Pinilla Navarro (ed.), Gestión y usos del agua en la cuenca del Ebro en el siglo XX (2008).

69 Juan Mainer (coord.), Pensar críticamente la educación escolar. Perspectivas y controversias historiográficas (2008).

70 Richard Hocquellet, Resistencia y revolución durante la Guerra de la Independencia. Del levantamiento patriótico a la soberanía nacional (2008).

71 Xavier Darcos, La escuela republicana en Francia: obligatoria, gratuita y laica. La escuela de Jules Ferry, 1880-1905 (2008). 
a calle Predicadores es la prolongación extramuros del decumanus maximus en la parte occidental de Caesaraugusta y debió de ser usada como vía funeraria. El hallazgo fue fruto de la excavación de varios solares contiguos. Un pequeño monumento, del tipo bustum con aedicula en bóveda, y su tubo libatorio, que comunicaba con la urna de cenizas, participan de una costumbre funeraria ligada a la costa mediterránea y, en particular, italiana y africana, que se adopta algo después en regiones orientales europeas, entre finales del siglo II y en el III, tiempo en el que se sitúa este hallazgo de Zaragoza: razones hay para sugerir que este pequeño mausoleo fuera el núcleo aglutinante al que se fueron sumando otras inhumaciones en la misma época. Estas últimas presentaban una tipología similar entre sí y correspondian casi todas a hombres jóvenes.

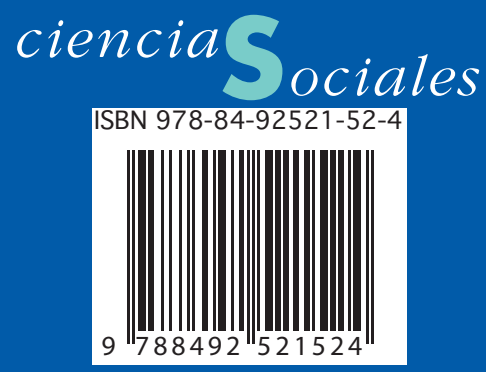

